Universidade de São Paulo

Faculdade de Filosofia, Letras e Ciências Humanas

Departamento de Ciência Política

\title{
Amazônia: pensamento e presença militar
}

Adriana Aparecida Marques

Tese apresentada ao
Programa de Pós-Graduação
do Departamento de Ciência
Política da Faculdade de
Filosofia e Ciências
Humanas da Universidade
de São Paulo, para a
obtenção do título de Doutor
em Ciência Política.

Orientação: Prof. Dr. Rafael A. Duarte Villa 
Dedico esta tese aos meus pais,

Cida Corazza e Laurindo Marques 


\section{AGRADECIMENTOS}

Gostaria de agradecer a algumas instituições e pessoas sem as quais a realização desta pesquisa não seria possível. Primeiramente, agradeço ao Programa de Doutorado em Ciência Política da Universidade de São Paulo e à Coordenação de Aperfeiçoamento de Pessoal de Nível Superior pela bolsa de estudos que me permitiu a dedicação exclusiva à confecção da tese e a realização de um estágio no exterior.

Agradeço também ao meu orientador Rafael Villa por todo apoio e incentivo durante os quatro anos do doutorado. Sou igualmente grata aos professores Gabriel Cohn e Shiguenoli Miyamoto pelos comentários sobre meu projeto de pesquisa, e ao professor Alcides Vaz pela participação na banca examinadora - lembrando sempre que todas as falhas de interpretação são de minha inteira responsabilidade. A Celso Castro devo o acesso a uma bibliografia muito interessante, sem a qual certamente esta tese estaria mais pobre, e o apoio para a realização do meu estágio nos Estados Unidos.

Da terra do Tio Sam gostaria de agradecer muitíssimo a James $\mathrm{N}$. Green, meu co-orientador, pela acolhida na Universidade Brown. Minha estadia no Watson Institute for International Studies foi um período muito profícuo para reflexão sobre alguns temas que esta tese aborda. Agradeço igualmente a Antônio Jorge R. Ramalho, do Ministério da Defesa, pelo auxílio à minha pesquisa em Brasília, ao coronel Manuel Cambeses por me receber no Instituto Histórico e Cultural da Aeronáutica e disponibilizar um material sobre a Força Aérea na Amazônia, e ao almirante Armando Vidigal pela entrevista concedida.

Sou especialmente grata a Eliézer Rizzo de Oliveira, meu orientador na graduação e no Mestrado, com quem tive o privilégio de aprender o "ofício" de pesquisadora. Meu muito obrigado à Suzeley K. Mathias, Samuel A. Soares, Paulo R. Kulhmann, Cláudio C. Silveira, Juliana Viggiano, Flávia Rossi e Carolina El Debs, companheiros no estudo da "milicologia" e das relações internacionais, mas sobretudo amigos queridos. 
Agradeço aos funcionários civis e militares das bibliotecas da EGN, ECEME e ECEMAR, sempre prestativos e competentes, e às secretárias do Departamento de Ciência Política, igualmente prestativas e competentes.

À família do meu companheiro, João Paulo Rodrigues, agradeço o apoio durante o período em que estive no Rio de Janeiro e à minha família nuclear, mãe, pai, e André, agradeço por suportarem com distinção e louvor minha volta para casa para fazer o doutorado em São Paulo. Ao clã dos Corazza, em particular às minhas tias Imaculada e Cristina, agradeço por segurarem as pontas sempre que as coisas ficam difíceis e ao meu irmão Maurício por estar sempre ao meu lado, mesmo morando do outro lado do Oceano Atlântico. A João Paulo por todo carinho, atenção e solidariedade durante dez anos e duas teses, também tenho muito a agradecer e sei que terminar mais este texto agora já é um bom começo. 


\section{RESUMO}

A tese analisa o pensamento dos militares sobre a Amazônia brasileira e a escolha das estratégias das Forças Armadas para defender a região, dando uma especial atenção às modalidades de sua presença na área. A pesquisa mostra que a identificação da Amazônia como prioridade estratégica das Forças Armadas não se deve apenas a uma reconfiguração dos interesses estatais em matéria de segurança e defesa. A importância atribuída à região amazônica pelos militares resulta de uma intrincada relação entre interesses e elementos simbólicos. $O$ primeiro capítulo apresenta o debate acadêmico entre neorealistas, organizativistas e construtivistas sobre o que determina a adoção de uma doutrina militar por um Estado. O segundo capítulo analisa o discurso dos militares sobre a região amazônica e as transformações deste discurso ao longo das duas últimas décadas, dando especial atenção ao discurso do Exército. O terceiro capítulo examina a presença do Exército na Amazônia e as estratégias militares elaboradas para defendê-la. O quarto capítulo trata das percepções da Força Aérea e da Marinha sobre os problemas de Defesa Nacional na Amazônia. E o quinto capítulo aborda a percepção dos formuladores de política civis sobre a problemática amazônica e as medidas adotadas para incrementar a defesa militar da região. A principal fonte de pesquisa desta tese é a bibliografia militar, composta por discursos, entrevistas, documentos doutrinários, revistas, livros de memórias, e monografias de final de curso das Escolas de Comando e EstadoMaior das Forças Armadas. Para a elaboração desta pesquisa também foi consultada uma bibliografia acadêmica que trata das relações entre os civis e os militares no Brasil, de sociologia militar, e de relações internacionais. Ademais, foram consultados documentos parlamentares, como os anais da Câmara de Deputados e do Senado Federal, assim como os arquivos eletrônicos disponíveis na internet referentes aos partidos políticos brasileiros, aos Ministérios das Relações Exteriores, e da Defesa.

Palavras-Chave: Brasil, Forças Armadas, Defesa Nacional, Cultura Estratégica, Amazônia. 


\begin{abstract}
This thesis analyzes the Brazilian Armed Forces strategic thought about the Amazon and the military presence in the region. It shows that the identification of the Amazon as a strategic priority to Brazilian military is not due only to a reconfiguration of state security and defense interests. The importance given to the region by the military service derives from a framework of interests and symbolical elements. The first chapter presents the academic debate among neorealism, organization theory and constructivism about the origins of military doctrine. The second chapter analyzes the military discourse about the Amazon and its changes over the last two decades, giving special attention to the Army. The third chapter focuses the Army presence in the Amazon and the military strategies to its defense. The fourth chapter deals with the Navy and the Air Force perceptions on the Amazon security problems. The fifth chapter presents the civilian perceptions on the Amazon problem and the policies adopted in order to increase the military defense of the region. The main source of this research is the Armed Forces bibliography, which is composed by speeches, interviews, doctrinaire documents, military magazines, memory books and Military Academies degree monographies. An academic bibliography dealing with civil-military relations in Brazil, military sociology and international relations was also adopted. Besides, the thesis dealt with parliamentary documents (as the Proceeding of the Chamber of Deputies and of the Federal Senate), as well as internet electronic archives referring to political parties, Ministry of Foreign Affairs and Ministry of Defense.
\end{abstract}

Keywords: Brazil, Armed Forces, National Defense, Strategic Culture, Amazon. 


\section{LISTA DE ABREVIATURAS E SIGLAS}

$A C-$ Acre

ALCA - Área de Livre Comércio das Américas

AM - Amazonas

ANAC - Agência Nacional de Aviação Civil

AP - Amapá

ARENA - Aliança Renovadora Nacional

BA - Bahia

BABE - Base Aérea de Belém

BABV - Base Aérea de Boa Vista

BAMN - Base Aérea de Manaus

BEC - Batalhão de Engenharia de Construção

BID - Banco Interamericano de Desenvolvimento

BIS - Batalhão de Infantaria de Selva

BNFAE/MN - Batalhão de Infantaria da Aeronáutica Especial de Manaus

CAM - Correio Aéreo Militar

CAN - Correio Aéreo Nacional

CEA - Conferência dos Exércitos Americanos

CF - Constituição Federal

CIABA - Centro de Instrução Almirante Braz de Aguiar

CIGS - Centro de Instrução de Guerra na Selva

CIMI - Conselho Indigenista Missionário

CINDACTA - Centro Integrado de Defesa Aérea e Controle do Tráfego Aéreo

CMA - Comando Militar da Amazônia 
COMAR - Comando Aéreo Regional

COMAER - Comando da Aeronáutica

COMARA - Comissão de Aeroportos da Região Amazônica

COMDABRA - Comando de Defesa Aeroespacial Brasileiro

COMGAP - Comando-Geral de Apoio

COMGAR - Comando Geral de Operações Aéreas

COMGEP - Comando-Geral do Pessoal

ComOpNav - Comando de Operações Navais

CONFESA - Conselho Superior de Economia e Finanças da Aeronáutica

CPDOC - Centro de Pesquisa e Documentação de História Contemporânea do Brasil.

CREDN - Comissão de Relações Exteriores e Defesa Nacional

C-SAR - Combat Search And Rescue

CTA - Comando-Geral de Tecnologia Aeroespacial

DAC - Departamento de Aviação Civil

DASG - Destacamento de Aeronáutica de São Gabriel da Cachoeira

DECEA - Departamento de Controle do Espaço Aéreo

DEM - Democratas

DEPENS - Departamento de Ensino da Aeronáutica

DF - Distrito Federal

DN - Distrito Naval

ECEMAR - Escola de Comando e Estado-Maior da Aeronáutica

ECEME - Escola de Comando e Estado-Maior do Exército

EGN - Escola de Guerra Naval

ELO - Esquadrilha de Ligação e Observação

EMD - Estado-Maior de Defesa 
EMFA - Estado-Maior das Forças Armadas

ETA - Esquadrão de Transporte Aéreo

EUA - Estados Unidos da América

G-7 - Grupo dos 7

GEC - Grupamento de Engenharia de Construção

GLO - Garantia da Lei e da Ordem

GTI - Grupo de Trabalho Interministerial

FAB - Força Aérea Brasileira

FAE - Força Aérea

FARCs - Forças Armadas Revolucionárias da Colômbia

FGV - Fundação Getúlio Vargas

Flotam - Flotilha do Amazonas

FUNAI - Fundação Nacional do Índio

GAV - Grupo de Aviação

IITC - International Indian Treaty Council

ITA - Instituto Tecnológico de Aeronáutica

MA - Maranhão

$\mathrm{MCl}$ - Movimento Comunista Internacional

MERCOSUL - Mercado Comum do Sul

MEVA - Missão Evangélica da Amazônia

MG - Minas Gerais

MOMEP - Missão de Observadores Militares Equador - Peru

MT - Mato Grosso

MS - Mato Grosso do Sul

ONU - Organização das Nações Unidas

ONGs - Organizações Não Governamentais 
OTAN - Organização do Tratado do Atlântico Norte

PA - Pará

PABE - Prefeitura de Aeronáutica de Belém

PABV - Prefeitura de Aeronáutica de Boa Vista

PAPV - Prefeitura de Aeronáutica de Porto Velho

PC - Plataforma Continental

PCB - Partido Comunista Brasileiro

PCdoB - Partido Comunista do Brasil

PCN - Programa Calha Norte

PDN - Política de Defesa Nacional

PDS - Partido Democrático Social

PDT - Partido Democrático Trabalhista

PEF - Pelotões Especiais de Fronteira

PPG7 - Programa Piloto para a Proteção das Florestas Tropicais do Brasil

PFL - Partido da Frente Liberal

PMDB - Partido do Movimento Democrático Brasileiro

PMN - Partido da Mobilização Nacional

PP - Partido Progressista

PPB - Partido Progressista Brasileiro

PPR - Partido Progressista Reformador

PPS - Partido Popular Socialista

PR - Partido da República

PR - Paraná

PRONA - Partido de Reedificação da Ordem Nacional

PSB - Partido Socialista Brasileiro

PSDB - Partido da Social Democracia Brasileira 
PSOL - Partido Socialismo e Liberdade

PT - Partido dos Trabalhadores

PTB - Partido Trabalhista Brasileiro

PV - Partido Verde

RADAM - Radar da Amazônia

RJ - Rio de Janeiro

RN - Rio Grande do Norte

RO - Rondônia

RR - Roraima

RS - Rio Grande do Sul

$\mathrm{SC}$ - Santa Catarina

SP - São Paulo

SIPAM - Sistema de Proteção da Amazônia

SIPLEX - Sistema de Planejamento do Exército

SISDABRA - Sistema de Defesa Aeroespacial Brasileiro

SISDACTA - Sistema Integrado de Defesa Aérea e Controle do Tráfego Aéreo

SIVAM - Sistema de Vigilância da Amazônia

SPVEA - Superintendência do Plano de Valorização Econômica da Amazônia

SUDAM - Superintendência de Desenvolvimento da Amazônia

TCA - Tratado de Cooperação Amazônica

TIRSS - Terra Indígena Raposa Serra do Sol

URSS - União das Repúblicas Socialistas Soviéticas

ZEE - Zona Econômica Exclusiva 


\section{LISTA DE FIGURAS}

Figura 1 - Mapa das Organizações Militares do Exército

Figura 2 - Ordem de Batalha

81

Figura 3 - Tríade da Soberania

83

Figura 4 - Medalha do Serviço Amazônico

85

Figuras 5 e 6 - Cartazes da Força de Resistência

104

Figura 7 - Chapéu Bandeirante

112

Figura 8 - Distintivo do Comando Militar da Amazônia 113

Figura 9 - Comandos Aéreos Regionais 126

Figura 10 - Amazônia Azul 144

Figura 11 - Mapa das Organizações Militares da Marinha 147 


\section{SUMÁRIO}

Introdução 15

Capítulo I: Segurança estatal, cultura estratégica e doutrina militar 28

1. As contribuições da teoria da organização e do neorealismo para o estudo das doutrinas militares

2. A crítica construtivista às abordagens neorealista e organizativista 38

3. Cultura estratégica: um conceito em construção 41

Capítulo II: A representação da Amazônia no discurso militar $\quad 46$

1. Linhas gerais do pensamento militar sobre a Amazônia 46

2. As mudanças estruturais nos contextos internacional, regional e nacional e a resignificação da Amazônia pelo Exército 59

2.1. A nova ordem internacional 59

2.2. Conflito e cooperação na América do Sul 69

2.3. Os problemas nacionais $\quad 75$

Capítulo III: O Exército na Amazônia: construindo estratégias e mitos

1. A presença castrense na Amazônia e a construção das estratégias militares para a região $\quad 77$

1.1. O perfil organizacional do Exército na Amazônia 77

1.2. A estratégia da presença $\quad 87$

1.3. A estratégia da resistência $\quad 95$

2. A mística da Amazônia 108

2.1. Pedro Teixeira: o Conquistador da Amazônia 110

2.2. Os bandeirantes modernos 111

2.3. Os guerreiros de selva e o espírito de Guararapes 114

Capítulo IV: A Força Aérea e a Marinha na Amazônia: forças coadjuvantes da presença estatal 117

1. As duas faces da Aeronáutica no Brasil 117

2. A presença da Força Aérea na Amazônia: um breve histórico 120

2.1. Estrutura organizacional da Força Aérea na Amazônia 125

2.1.1. A Lei do Tiro de Destruição, os Atos Internacionais e as Operações Aéreas Bilaterais 
3. A Marinha na Amazônia 139

3.1. A Amazônia Azul

3.2. Mito de origem e realidade histórica da presença naval na Amazônia

3.3. Estrutura organizacional da Marinha na Amazônia na atualidade

3.4. O Batalhão de Operações Ribeirinhas 152

Capítulo V: Executivo, Legislativo e Segurança Militar da Amazônia 155

1. As iniciativas governamentais para a proteção da Amazônia 155

1.1. O Tratado de Cooperação Amazônica e a Organização do Tratado de Cooperação Amazônica

1.2. O Programa Calha Norte 157

1.3. O Projeto SIPAM/SIVAM 159

2. A criação do Ministério da Defesa no Brasil e seus impactos sobre a atuação das Forças Armadas na Amazônia 161

2.1. A Política de Defesa Nacional 165

2.2. A estrutura organizacional e as funções do Ministério da Defesa 167

3. Poder Legislativo e Presença Militar na Amazônia 170

3.1. A defesa da Amazônia nos documentos partidários 172

3.2. O debate sobre a Amazônia nas Comissões de Relações

Exteriores e Defesa Nacional 180

Considerações Finais 190

Anexo 1 - Portaria n. 020 - EME, de 2 de abril de $2003 \quad 194$

Anexo 2 - Canção do $6^{\circ}$ BEC 198

Anexo 3 - Canção do Soldado da Amazônia 200

Anexo 4 - Oração do Guerreiro de Selva 201

Anexo 5 - Canção do Centro de Instrução de Guerra na Selva 202

Anexo 5 - Sentinela Amazônida 203

Anexo 6 - Bandeirante do Ar 204

Anexo 7- Canção do VII COMAR 205

Referências Bibliográficas $\quad 207$ 


\section{INTRODUÇÃO}

Tancredo Neves - primeiro presidente civil eleito após 21 anos de ditadura militar - cunhou um termo para definir o período do seu futuro governo: a Nova República. Esta nova fase da vida política brasileira, em decorrência de uma conjuntura histórica muito particular, nasceu sob o signo da tutela militar ${ }^{1}$.

Em janeiro de 1985, quando o Colégio Eleitoral elegeu Tancredo Neves, os militares brasileiros desempenhavam dois papéis no país: eram governo, ocupando o centro do poder político na figura de seus generaispresidentes, e eram instituição responsável por garantir, pela força das armas, a segurança estatal, como observou com propriedade Alfred Stepan (1986).

A internação do presidente eleito para uma cirurgia de emergência às vésperas da posse gerou um clima de incerteza jurídica e política sobre a sucessão presidencial. Havia o temor de que os militares se recusassem a empossar José Sarney, o vice-presidente eleito. Havia igualmente uma certa apreensão sobre como os opositores da ditadura veriam a posse de alguém que até bem pouco tempo tinha sido membro da ARENA².

\footnotetext{
${ }^{1}$ Eliézer Rizzo de Oliveira, emprega o conceito de tutela militar, "para designar uma situação na qual um governo politicamente frágil de apoio partidário e parlamentar encontra nas Forças Armadas a fonte primeira de sua estabilidade, ao preço de preservar os traços básicos da experiência militar recente: um grau elevado de autonomia política do aparelho militar quanto à definição da estratégia nacional; o exercício da função interventora; um grau por vezes disfuncional, porque extremamente abrangente, de interferência dos ministros militares em assuntos extramilitares; a afirmação do Exército como a Força por excelência para a estabilidade do regime. O presidente Sarney e o ministro Leônidas Pires Gonçalves foram os atores principais deste cenário de tutela militar (Oliveira, 1994:206)."

${ }^{2}$ A Aliança Renovadora Nacional (ARENA) foi o partido que deu sustentação à ditadura militar.
} 
As dúvidas sobre a sucessão presidencial foram dissipadas quando o general Leônidas Pires Gonçalves ${ }^{3}$, que representava naquele momento - Exército enquanto instituição, avalizou a interpretação do texto constitucional que garantia a posse do vice-presidente. No dia seguinte Sarney foi empossado e os militares voltaram aos quartéis.

O fim da ditadura militar no Brasil impulsionou várias e profundas mudanças políticas. No âmbito da política externa, a chamada Nova República iniciou o processo de aproximação com a Argentina, que também havia se redemocratizado há poucos $a_{n o s}{ }^{4}$, e contribuiu para o arrefecimento da antiga rivalidade entre os dois vizinhos (Marques, 2001).

A intensificação da cooperação entre brasileiros e argentinos, que culminou na criação do Mercosul ${ }^{5}$, deu-se num período de mudanças significativas na ordem internacional. Os governos do Estados Unidos e da União Soviética, em franco processo de distensão desde que Mikhail Gorbachev $^{6}$ assumiu o poder, estavam próximos de porem fim à Guerra Fria que há quase meio século ordenava as relações entre os Estados.

$\mathrm{Na}$ visão dos militares brasileiros a reconfiguração da ordem internacional não levou a um patamar de convivência entre os Estados no

${ }^{3}$ O general Leônidas Pires havia sido escolhido por Tancredo Neves para ser o novo ministro do Exército. Sua visão sobre o papel dos militares no processo de redemocratização do país está expressa no depoimento dado aos pesquisadores da Fundação Getúlio Vargas: "Quem começou a abertura, meio timidamente, mas começou, foi o general Geisel. Figueiredo escancarou e nós concordamos. (...) Este país virou democracia porque nós desejávamos que fosse assim (Soares; Castro; D’Araujo 1995:181)".

${ }^{4}$ A ditadura argentina ruiu após a derrota militar na Guerra das Malvinas. Em outubro de 1983, o civil Raul Alfonsín foi eleito presidente encerrando um período de 07 anos de regime militar.

${ }^{5}$ O Tratado para a Constituição do Mercado Comum do Sul (Mercosul) foi assinado em 1991 e entrou em vigor em 1994.

${ }^{6}$ Mikhail Gorbachev assumiu o poder na União Soviética (URSS) em 1985 e implementou um conjunto de reformas estruturais na economia e na política soviética, substituindo a economia planificada pela economia de mercado e promovendo a democratização da vida política na confederação. No âmbito das relações exteriores, Gorbachev acelerou o processo de aproximação da URSS com os países ocidentais. 
qual o uso da Força estivesse excluído. Dito de outra forma, a ordem unipolar estabelecida após a débâcle da União Soviética, no início da década de 1990, não trouxe a pax americana, como sugeriram alguns analistas. ${ }^{7}$ Mas é certo que o fim da possibilidade de um confronto bélico direto entre os dois grandes blocos estratégico-militares capitaneados pelos Estados Unidos e a União Soviética mudou a percepção do que poderia ou não ser considerado como uma ameaça à segurança dos Estados nacionais.

Neste novo contexto, questões antes relegadas em razão da Guerra Fria, tais como, devastação ambiental, desrespeito aos direitos humanos, conflitos étnicos, correntes migratórias internacionais, terrorismo, corridas armamentistas regionais, proliferação de armas de destruição em massa e ilícitos transnacionais ${ }^{8}$, ganharam destaque na agenda de segurança internacional.

Alçadas à categoria de "novas ameaças", as questões supracitadas tornaram-se passíveis de "securitização" por Estados, Organizações Internacionais ou mesmo atores não-estatais ${ }^{10}$. Uma vez identificados como ameaças à segurança internacional, problemas como a devastação ambiental ou o desrespeito aos direitos humanos podem vir a justificar ações militares.

\footnotetext{
${ }^{7}$ Sobre a percepção brasileira acerca do cenário internacional que estava se configurando no pós-Guerra Fria, ver a exposição do então Ministro das Relações Exteriores Luís Felipe Lampreia no II Encontro Nacional de Estudos Estratégicos em 1995: Lampreia (1995).

${ }^{8}$ Contrabando de armas, lavagem de dinheiro, tráfico de drogas, etc.

${ }^{9}$ A securitização é um processo intersubjetivo e socialmente construído. Para que uma questão seja securitizada é necessário que a opinião pública respalde o discurso de um ator "securitizador" (que pode ser um representante do governo ou um ator não-estatal, como, por exemplo, o membro de uma ONG) sobre a existência de uma ameaça que pode comprometer a sobrevivência de um determinado objeto de referência (o Estado, a cultura de uma sociedade, o meio ambiente, um grupo étnico, etc.) e a adoção de medidas emergenciais e fora dos parâmetros normais do procedimento político (Buzan, Wæver, Wilde, 1998:21-47).

10 Para uma discussão a respeito da atuação dos atores não-estatais na arena internacional ver: Villa (2004).
} 
Este ponto mereceu atenção especial das Forças Armadas que decidiram reavaliar as vulnerabilidades estratégicas ${ }^{11}$ do país à luz das mudanças na agenda de segurança e no panorama estratégico sulamericano, pois se nas fronteiras sulinas o cenário era pacífico, o mesmo não se aplicava às fronteiras do norte. Os militares viam com preocupação a existência de grupos guerrilheiros atuando nos lindes da Amazônia brasileira, as disputas territoriais entre Peru e Equador, e a possibilidade de que a Venezuela e a Guiana quisessem rever suas fronteiras com o Brasil, entre outros fatores.

No processo de reavaliação das vulnerabilidades estratégicas brasileiras, as fronteiras amazônicas, até então colocadas em segundo plano, foram identificadas como o principal foco de problemas em matéria de segurança e defesa, o que acarretou um conjunto de modificações nas concepções doutrinárias e organizacionais das Forças Armadas brasileiras.

Estas mudanças no imaginário e na atuação dos fardados suscitam as seguintes questões: a partir de que ideário os militares constroem suas percepções de ameaças à integridade territorial do país e à soberania nacional, tendo em conta as mudanças operadas nas próprias concepções de segurança nas últimas décadas? Os militares enquanto instituição monopolizam a fixação da agenda de segurança e defesa para a região amazônica? Como os outros atores estatais vêem o papel desempenhado pelas Forças Armadas na Amazônia? Qual a importância simbólica da Amazônia para os militares brasileiros?

Uma pesquisa que busque interconexões entre as percepções castrenses sobre a Amazônia e a presença militar na área - que ocupa aproximadamente $50 \%$ do território nacional - revelará que a identificação da Amazônia como prioridade estratégica das Forças Armadas não se deve apenas a uma reconfiguração dos interesses estatais em matéria de

\footnotetext{
${ }^{11}$ Uma das inovações introduzidas nas Forças Armadas brasileiras após o fim da Guerra Fria foi a substituição do conceito de hipótese de guerra por vulnerabilidade estratégica. Um dos defensores desta mudança conceitual, o almirante Armando Vidigal, apresenta seu argumento em: Vidigal (1990).
} 
segurança. A importância atribuída à região amazônica pelos fardados resulta de uma intrincada relação entre interesses e elementos simbólicos.

Essa investigação também constatará que, mesmo compartilhando a idéia de que a Amazônia é a principal vulnerabilidade estratégica do país, as três Forças Armadas interpretam de maneira bastante particular como devem se preparar para defender a região. Interpretação esta que é orientada pela cultura organizacional de cada uma das Forças.

Partindo das hipóteses acima, esta tese analisará o pensamento dos militares sobre a Amazônia brasileira e a escolha das estratégias militares para defender a região, dando uma especial atenção às modalidades de presença militar na área.

Presença não é entendida aqui apenas como a distribuição geográfica das tropas, mas abarca a dimensão material e simbólica da existência de uma unidade militar numa determinada localidade. Os estudos realizados sobre a presença de unidades militares norteamericanas no próprio país, na Europa, e na Ásia apontam que a relação estabelecida entre estas bases e a população local é mais complexa do que se supõe. ${ }^{12}$

\footnotetext{
${ }^{12}$ A antropóloga Catherine Lutz vê com ceticismo a presença de unidades militares em regiões pobres. Para a autora a presença, por exemplo, de Fort Bragg em Fayetteville, na Carolina do Norte gerou uma enorme dependência econômica da cidade em relação à unidade militar, além de contribuir para o aumento da violência, prostituição, etc. (Lutz, 2001). Estudando a presença de bases militares norte-americanas na Ásia e na Europa, Alexander Cooley enfatiza a relação ambígua dos políticos locais em relação à presença das bases militares norte-americanas. Ambigüidade esta expressa da seguinte forma: é comum os candidatos a cargos eletivos em localidades que possuem bases militares norte-americanas utilizarem uma retórica fortemente anti-americanista, defendendo o fechamento das bases, durante a campanha política. Contudo, uma vez eleitos estes candidatos pouco se empenham pelo fechamento das bases, por diferentes razões. Em países como Espanha e a Grécia, o discurso anti-bases estava relacionado ao processo de democratização da sociedade. Após a consolidação da democracia nesses países, o discurso anti-bases perdeu força, dando lugar a uma postura mais cautelosa que enfatiza a cooperação em assuntos de segurança internacional. Um processo parecido ocorre na Coréia do Sul atualmente (Cooley, 2005). Já no Japão, o discurso anti-bases tem um forte
} 
Ainda sobre esta pesquisa é necessário fazer alguns esclarecimentos. Em primeiro lugar, o objeto desta tese não é a Amazônia. O foco desta investigação é a percepção dos militares acerca dos problemas de segurança e defesa na região a partir da instauração da Nova República, ou seja, a partir do momento em que os militares deixaram de ser governo para ser apenas instituição.

Em certa medida esta pesquisa também procura aprofundar a discussão de algumas questões que eu não pude explorar a contento em minha dissertação de mestrado (Marques, 2001). No trabalho anterior minha preocupação central era analisar o pensamento militar sobre Defesa Nacional - um tema mais amplo. Ademais, darei continuidade à análise comparada do pensamento de cada uma das três Forças Armadas sobre estratégia militar, uma matéria extremamente interessante, porém pouco explorada pela bibliografia sobre os militares brasileiros.

Se já se consolidou na bibliografia que estuda as relações entre civis e militares a tese de que os militares não são um grupo monolítico (Rouquié, 1991; Oliveira, 1994; Martins, 1995; Mathias, 1995; Soares, 2000; Castro\&D'Araujo, 2001) pouco se sabe sobre como as diferentes correntes de pensamento existentes no interior das Forças Armadas brasileiras, e no interior de cada Força, atuam para fazer com que suas idéias prevaleçam.

Para sanar esta lacuna, alguns pesquisadores têm se dedicado a estudar com mais vagar o pensamento de apenas uma das três Forças Armadas $^{13}$. Esta estratégia de pesquisa é válida e necessária. Contudo,

apelo ideológico. Porém isto não é capaz de suplantar a dependência econômica de determinadas localidades em relação às bases militares norte-americanas (Cooley, 2006).

${ }^{13}$ As pesquisas sobre o Exército são mais numerosas e antigas. Nas décadas de $1970 \mathrm{e}$ 1980 , os pesquisadores - com raras exceções, como Manuel Domingos Neto que estudou a Missão Militar Francesa (Domingos Neto, 1991) - enfocavam o papel desempenhado pela instituição na política nacional (Holanda, 1985; Trevisan, 1985; Oliveira, 1987; Trevisan, 1987; Peixoto, 1991; Coelho, 2000; Carvalho, 2005). A partir da década de 1990 começaram a surgir mais pesquisas sobre aspectos organizacionais e culturais das Forças Armadas. O Exército ainda mobiliza muito mais a atenção dos pesquisadores (Soares, 1994; Leirner, 1997; Kuhlmann, 2001; Fázio, 2003; Castro, 2004; Maximiano, 2004; 
não dirime o fato de que precisamos de mais estudos que apontem os pontos de convergência e divergência entre as três Forças Armadas sobre temas como: qual deve ser o perfil organizacional do aparelho militar brasileiro? Devemos manter o serviço militar obrigatório? O Exército deve ser utilizado no combate ao crime e na repressão ao tráfico de drogas e de armas? Devemos ter uma Marinha costeira ou oceânica? Qual deve ser a principal missão da Força Aérea? Que tipo de armamentos devemos privilegiar?

Os estudos de sociologia militar (Posen, 1984) e a experiência histórica ensinam que somente os dirigentes políticos podem arbitrar as divergências doutrinárias e organizacionais entre as três Forças Armadas. Na falta de uma imposição externa, os militares invariavelmente optam por uma saída negociada, com cada uma das Forças preservando sua autonomia para decidir sobre o próprio perfil doutrinário e organizacional.

Um bom exemplo da importância da arbitragem dos dirigentes políticos sobre questões militares pode ser encontrado no processo de criação da Força Aérea Brasileira (FAB), em janeiro de 1941. Após o sucesso dos bombardeios aero-estratégicos durante a Segunda Guerra Mundial, ganhou força no meio castrense a demanda de um grupo de aviadores do Exército e da Marinha que advogavam a necessidade de uma Força Aérea independente. Os Estados-Maiores do Exército e da Marinha eram contra esta reivindicação. O presidente Getúlio Vargas, contrariando a disposição do Alto Comando, decidiu atender as reivindicações dos militares aviadores, extinguindo a aviação naval e a aviação do Exército e criando a Força Aérea Nacional, mais tarde rebatizada como Força Aérea Brasileira (Marques, 2001).

No que concerne à preocupação militar com a Amazônia, é natural que - por tratar-se de um teatro de operações terrestres - o Exército tenha

Mendes, 2004; Puntoni, 2004; Souza, 2004). A Força Aérea que tradicionalmente foi relegada - uma exceção é a pesquisa de Takahashi (2002) - despertou o interesse acadêmico nos últimos anos em razão do projeto SIVAM (Falconi, 2005; Oliveira, 2005). Já a Marinha ainda conta com poucas pesquisas (Nascimento, 1999; Silveira, 2002; Fonseca, 2004). 
um papel preponderante na execução da estratégia de defesa militar da região; por isso, esta tese privilegia as percepções da Força Terrestre sobre a região amazônica.

O historiador francês Alain Rouquié costumava congratular os seus orientandos brasileiros que estudavam as Forças Armadas "por que os seus militares escreviam" ${ }^{14}$. De fato, a verve com que os fardados escrevem facilita a realização de uma investigação acadêmica sobre a instituição. Por isso, a principal fonte de pesquisa desta tese é a bibliografia militar, composta por discursos, entrevistas, documentos doutrinários, revistas, livros de memórias, e monografias de final de curso das Escolas de Comando e Estado-Maior das Forças Armadas. Esta bibliografia militar merece alguns comentários.

As revistas que foram consultadas têm um perfil bem variado. $O$ discurso oficial dos militares e os temas que mais preocupam a instituição podem ser mapeados a partir da leitura de publicações como a Revista Marítima Brasileira, A Defesa Nacional, a Revista do Exército Brasileiro, a Aerovisão e a Revista da Força Aérea. Um tom mais reivindicatório e, às vezes, alarmista, a respeito das demandas castrenses é adotado em publicações que pertencem a associações de militares da reserva como o Clube Militar e o Instituto Histórico-Cultural da Aeronáutica.

As páginas oficiais das Forças Armadas e do Ministério da Defesa na internet também são uma fonte de pesquisa valiosa, pois disponibilizam informações sobre as operações militares realizadas na Amazônia.

Sobre as monografias de final de curso é importante destacar que os textos produzidos pelos alunos das Escolas de Comando e Estado-Maior apesar de não terem o mesmo peso institucional e simbólico de um documento oficial ou de um discurso proferido pelos comandantes militares - devem ser encarados como um conjunto de "discursos legitimados pela instituição" (Leirner, 1995), tendo em vista que os oficiais que os redigem "funcionam concomitantemente como formuladores de doutrina e "caixas de ressonância' na propagação da mentalidade militar (Soares, 1994:15)". Em

\footnotetext{
${ }^{14}$ Depoimento de Eliézer Rizzo de Oliveira.
} 
outras palavras, um oficial do Estado-Maior é o que Eliézer Rizzo de Oliveira define como intelectual militar:

O aparelho militar não é isolado do sistema político. Ao contrário, a aludida autonomia autárquica manifesta-se em pleno vigor na capacidade demonstrada pelo aparelho militar com relação ao processo político, em especial no tocante à dominação política na sociedade brasileira. Devemos tomar o conceito de dominação política como a capacidade de um grupo social para organizar ou para influenciar o exercício do poder estatal (...) a dominação política não pode dissociarse da função intelectual que, ao longo da história da sociedade brasileira, tem sido desempenhada largamente pelo grupo social formado pelos oficiais militares (...) Se considerarmos que o Estado produz políticas de cuja formulação os militares são chamadas a participar, é possível aplicar na análise as funções sociais que Gramsci atribui aos intelectuais, de modo a relacioná-las com o papel político dos militares brasileiros. Deste modo, como categoria profissional e política, estes militares têm desempenhado coletivamente a função social de intelectual do Estado, cujo objetivo é a participação na direção política do Estado (...) Diversos tipos de intelectuais militares concorrem para o processo de formação do pensamento da instituição. Há, em primeiro lugar, o tipo voltado ao desenvolvimento do próprio aparelho militar, cuja função, de âmbito eminentemente interno ao aparelho, cabe aos instrutores de tropas e oficiais de Estado-Maior. Esta função interna é primordialmente voltada para o próprio aparelho militar, mas não de maneira exclusiva. Ao menos dois elementos concorrem para esta abertura ao mundo exterior: a) a instrução militar fundamenta-se numa visão de mundo e da realidade política do país (...); b) as ações políticas e militares tendem a guardar algum tipo de relação, já que correspondem aos dois elementos fundadores do Estado (Oliveira, 1994;103-104).

Se a "verve literária" 15 dos militares brasileiros facilita, em certa medida, a compreensão da instituição, a aura de segredo que se criou em torno dos temas considerados de "segurança nacional" no Brasil dificulta o acesso dos pesquisadores aos arquivos militares. Em relação às dificuldades enfrentadas por esta pesquisa, destaco que tive permissão

\footnotetext{
${ }^{15}$ Não se discute aqui a qualidade dos escritos, mas a disposição de escrever.
} 
para consultar apenas os documentos considerados "ostensivos" pelas Forças Armadas.

Considerando as normas estabelecidas pelo Decreto n. 5.301, de 09 de dezembro de 2004, os documentos de arquivos oficiais considerados reservados e confidenciais deveriam ser desclassificados depois de 10 e 20 anos, respectivamente ${ }^{16}$. Por isso, em tese, um(a) pesquisador(a) civil no ano de 2005 teria o direito de consultar as monografias "confidenciais" escritas até 1985 e as reservadas escritas até 1995. Contudo, a falta de empenho do governo federal em determinar que as escolas militares apliquem as normas estabelecidas em 2004, faz com que nos estabelecimentos de ensino militar continue a vigorar o "sigilo eterno" de documentos que já deveriam ser ostensivos.

Por fim, as entrevistas com militares da reserva são um recurso muito interessante. Elas permitem esclarecer pontos e fazer conexões que não seriam possíveis caso fossem considerados apenas os depoimentos dos militares da ativa e os documentos oficiais. ${ }^{17}$ As regras rígidas de disciplina e hierarquia às quais os militares da ativa estão submetidos não admitem que oficiais façam críticas ou mesmo ilações acerca das diretrizes adotadas pelas Forças Armadas. Uma vez na reserva, os militares podem falar com mais liberdade sobre estas e outras questões.

Para a elaboração desta pesquisa também foi consultada uma vasta bibliografia acadêmica que trata das relações entre os civis e os militares no Brasil, de sociologia militar, e de relações internacionais.

\footnotetext{
${ }^{16}$ De acordo com o Decreto n. 5.301, os documentos considerados reservados devem permanecer classificados durante 05 anos e os considerados confidenciais devem permanecer classificados por 10 anos. "Os prazos de classificação poderão ser prorrogados uma vez, por igual período, pela autoridade responsável pela classificação ou autoridade hierarquicamente superior competente para dispor sobre a matéria" (Brasil, 2004a). Estou aqui considerando o prazo máximo de classificação dos documentos reservados e confidenciais.

17 O ciclo de entrevistas com oficiais da reserva realizados pelos pesquisadores do CPDOC-FGV é um exemplo bem sucedido neste sentido.
} 
Acerca da bibliografia sobre relações internacionais, gostaria de esclarecer que esta tese não tem a pretensão de testar a eficácia de uma determinada perspectiva teórica para explicar a construção das doutrinas militares no Brasil, já que não utilizamos uma metodologia positivista, segundo a qual a principal tarefa do analista é testar a capacidade de uma determinada teoria para explicar o comportamento dos atores sociais. Optamos por uma análise "interpretativista", cujo objetivo é interpretar o significado que os atores sociais atribuem às suas ações. No âmbito das Relações Internacionais, a proposta metodológica aqui adotada é utilizada pelos pesquisadores construtivistas.

Procuramos desta forma desatar um nó muito presente nos estudos sobre política de segurança e defesa: definir qual é a relação entre as idéias e o comportamento político. Acreditamos que este problema só se coloca quando se supõe que as idéias e as ações não são mutuamente constitutivas de forma exclusiva ou necessária.

Marshall Sahlins oferece uma definição precisa e elegante das interrelações entre os atores políticos e as estruturas sociais:

A história é ordenada culturalmente de diferentes modos nas diversas sociedades, de acordo com esquemas de significação das coisas. 0 contrário também é verdadeiro: esquemas culturais são ordenados historicamente porque em maior ou menor grau, os significados são reavaliados quando realizados na prática. A síntese desses contrários desdobra-se nas ações criativas dos sujeitos históricos, ou seja, as pessoas envolvidas. Porque, por um lado, as pessoas organizam seus projetos e dão sentido aos seus objetos partindo das compreensões preexistentes da ordem cultural. Nesses termos, a cultura é historicamente reproduzida na ação (...) Por outro lado, entretanto, como as circunstâncias contingentes da ação não se conformam necessariamente aos significados que lhes são atribuídos por grupos específicos, sabe-se que os homens criativamente repensam seus esquemas convencionais. É nesses termos que a cultura é alterada historicamente na ação. Poderíamos até falar de "transformação estrutural", pois a alteração de alguns sentidos muda a relação de posição entre as categorias culturais, havendo assim uma "mudança sistêmica" (Sahlins, 1990:07). 
Além da bibliografia militar e acadêmica, foram consultados documentos parlamentares, como os anais da Câmara de Deputados e do Senado Federal, assim como os arquivos eletrônicos disponíveis na internet referentes aos partidos políticos brasileiros, aos Ministérios das Relações Exteriores, e da Defesa. Esta documentação foi utilizada para identificar qual a visão dos formuladores de política civis acerca dos problemas de segurança e defesa na Amazônia, e qual deve ser o papel dos militares na região.

A tese está organizada da seguinte forma. O primeiro capítulo apresenta o debate acadêmico entre neorealistas, organizativistas e construtivistas sobre o que determina a adoção de uma doutrina militar por um Estado, além de definir os conceitos que serão empregados nesta tese. No segundo capítulo serão analisados o discurso dos militares sobre a região amazônica e suas transformações ao longo das duas últimas décadas, dando especial atenção ao discurso do Exército.

O terceiro capítulo examina a presença do Exército na Amazônia e as estratégias militares elaboradas para defendê-la. A primeira seção do capítulo investiga o perfil organizacional do Exército na Amazônia e as estratégias militares escolhidas para defendê-la: a presença e a resistência. E a segunda seção enfoca a importância simbólica da Amazônia para a Força Terrestre através dos mitos e canções que foram criados pela instituição acerca de sua presença e atuação na região.

O quarto capítulo trata das percepções da Força Aérea e da Marinha sobre os problemas de Defesa Nacional na Amazônia e as conseqüências organizacionais da prioridade estratégica da região para as duas Forças. As duas primeiras seções do capítulo mostram de forma concisa as peculiaridades da Aeronáutica brasileira, o papel desempenhado pela Força na região amazônica e sua estrutura organizacional na área. A terceira seção aborda a presença e a organização da Marinha na Amazônia Verde e relata qual é a importância simbólica da Amazônia Azul para a Força.

Por fim, no quinto capítulo veremos a percepção dos formuladores de política civis sobre a problemática amazônica e as medidas adotadas 
para incrementar a defesa militar da região. A primeira seção as iniciativas governamentais para a proteção da Amazônia. A segunda seção discute os impactos da criação do Ministério da Defesa para a organização da Defesa Nacional na região amazônica. E a terceira seção acompanha o debate parlamentar acerca da presença militar na área. 


\title{
CAPÍTULO I
}

\author{
SEGURANÇA ESTATAL, CULTURA ESTRATÉGICA E DOUTRINA \\ MILITAR
}

A principal fonte de segurança de um Estado contra ameaças externas no mundo contemporâneo é sua Força Militar. As condições e a maneira como cada Estado decide empregá-la é matéria de um extenso e acalorado debate acadêmico ${ }^{18}$.

Os especialistas em relações internacionais e Forças Armadas que estudam a elaboração de doutrinas e estratégias militares dividem-se, grosso modo, entre os que atribuem a preferência dos Estados por uma determinada estratégia militar aos constrangimentos e incentivos do sistema internacional, os neorealistas, e os que enfatizam as características organizacionais das Forças Armadas na escolha da estratégia a ser adotada, os partidários da teoria da organização. ${ }^{19}$

\footnotetext{
${ }^{18}$ É importante esclarecer que não há consenso entre os analistas sobre os conceitos de doutrina e estratégia militar. Por exemplo, o que Barry Posen (1984) e Elizabeth Kier (1997) chamam de doutrina, Jack Snyder (1984) denomina estratégia. A imprecisão dos conceitos utilizados por Kier é, aliás, uma das críticas mais contundentes ao seu trabalho (Porch, 2000:165). De todo modo, na discussão bibliográfica que será realizada neste capítulo preservaremos os conceitos adotados pelos autores. Quando estivermos tratando do caso brasileiro adotaremos o termo estratégia militar, que nos parece mais adequado para analisar o nosso objeto de estudo.

${ }^{19}$ Segundo a definição de uma importante obra de referência, o Dicionário de Política: "A expressão Teoria da organização é demasiado ampla e indefinida para se prestar a uma definição sintética e substantiva (...) Numa primeira análise diremos que a Teoria da organização é uma ciência social que estuda todas as organizações, fazendo-o desde uma perspectiva interdisciplinar (Bobbio, Matteucci e Pasquino, 2004:864)". No que concerne a aplicação da Teoria da organização nos estudos de Ciência Política: "Trata-se do estudo que se concentra na análise das funções 'políticas' mais ou menos latentemente desenvolvidas pelo aparelho da administração pública. $O$ ponto de partida, hoje amplamente conseguido e empiricamente válido, está em que os administradores de
} 
Mais recentemente alguns analistas têm discutido a elaboração de estratégias militares a partir de uma perspectiva construtivista, que não identifica a priori as preferências dos Estados ou o comportamento das burocracias nacionais como as duas perspectivas anteriores ${ }^{20}$, pois, de acordo com as premissas do construtivismo, não há como dissociar a elaboração e a execução de estratégias militares do contexto cultural no qual elas são produzidas. Os construtivistas não negam a importância dos fatores materiais na configuração da defesa militar, mas salientam que estes fatores podem ser interpretados de várias maneiras pelos atores sociais. ${ }^{21}$

profissão participam ativamente na formação das decisões político-administrativas e exercem um controle quase monopólico sobre as tecnologias de organização que regem a execução dessas mesmas decisões. Em outras palavras, trata-se do tema clássico da relação entre política e administração que está sendo sujeito à revisão crítica e à verificação empírica (Bobbio, Matteucci e Pasquino, 2004:869)".

20 Tanto o neorealismo quanto o ramo da Teoria da organização, que será analisado a seguir, priorizam as condições estruturais em detrimento das especificidades nacionais na análise da formulação das doutrinas militares. Nas palavras de Posen essas duas perspectivas teóricas assumem que os atores fazem o que podem com o poder que tem e o que devem com o poder dos outros. Elas também predizem comportamentos similares das unidades em contextos estruturais similares. O caráter estrutural das duas teorias permite, ainda de acordo com Posen, comparar e explicar variações nas doutrinas militares de Estados diferentes, Estados que são igualmente defendidos por organizações militares profissionais, mas ocupam posições distintas no sistema internacional (Posen, 1984:37).

${ }^{21}$ Marshall Sahlins no prefácio de seu livro Cultura e Razão Prática preconiza que "o debate entre o material e o significativo é a questão fatídica do pensamento social moderno. Para o autor a qualidade distintiva do ser humano não é o fato de que ele vive num mundo material, "circunstância que compartilha com todos os outros organismos, mas o fato de fazê-lo de acordo com um sistema significativo criado por si próprio, qualidade pela qual a humanidade é única. Por conseguinte, toma-se por qualidade decisiva da cultura - enquanto definidora para todo modo de vida das propriedades que o caracterizam - não o fato de essa cultura poder conformar-se a pressões materiais, mas o fato de fazêlo de acordo com um esquema simbólico definido, que nunca é o único possível. Por isso, é a cultura que constitui a utilidade (2003:07-08)". 


\section{As contribuições da teoria da organização e do neorealismo para o estudo das doutrinas militares}

Barry Posen, em The Sources of Military Doctrine, sumariza as principais hipóteses da teoria da organização e do neorealismo sobre o que determina a preferência dos Estados por uma doutrina militar.

A literatura organizativista ressalta que alguns atributos das organizações militares modernas ${ }^{22}$ afetam suas atitudes em relação a algumas dimensões das doutrinas militares como: (1) a escolha de doutrinas ofensivas, defensivas ou dissuasivas; (2) a integração entre civis e militares; (3) a inovação.

Quanto à escolha da doutrina a ser adotada, a teoria da organização prediz que os militares geralmente preferem doutrinas ofensivas, pois elas reduzem a incerteza. ${ }^{23} \mathrm{~A}$ necessidade de elaborar cenários e traçar planos de ação que possam ser executados de maneira previsível faz com que seja de extremo interesse das Forças Armadas impor seu cenário padrão ao adversário através de ações ofensivas antes que o adversário faça o mesmo. Ademais, a doutrina ofensiva não permite apenas que uma determinada força armada imponha seu cenário padrão ao adversário, ela também possibilita negar ao inimigo seu próprio cenário padrão. Em suma, os militares preferem lutar sua própria guerra e impedir seus inimigos de fazer o mesmo.

Tomando a ofensiva uma força militar pode conduzir a batalha e surpreender o inimigo. Já ao optar por uma doutrina defensiva, deve-se ter uma estrutura de comando flexível, pois é isto que garante a vitória neste caso. À força armada que escolhe a defensiva cabe aperfeiçoar com

\footnotetext{
${ }^{22}$ O Estado Moderno caracteriza-se por um intenso processo de especialização funcional e burocratização em decorrência do qual a função de Defesa Nacional é atribuída a um conjunto de especialistas. Entre estes especialistas, os militares assumem grande parte da responsabilidade pela elaboração da doutrina militar e sua execução em caso de guerra (Posen, 1984:42).

${ }^{23}$ Deve-se ressaltar que a grande maioria dos estudos sobre doutrinas militares deriva suas hipóteses da análise de doutrinas construídas e executadas pelo Exército.
} 
presteza sua doutrina para reagir à iniciativa do inimigo. Se esta força for capaz de aprender rapidamente como o inimigo luta, poderá destruir seus planos ofensivos e levar a batalha para o terreno da improvisação, um cenário que é igualmente desfavorável para as duas forças. Por isso, em tese, atacar primeiro beneficia quem toma a iniciativa, reduz sua necessidade de improvisação e a habilidade do inimigo improvisar. Esta seria mais uma vantagem da ofensiva.

Da mesma forma a doutrina dissuasiva não seria a primeira opção dos militares, pois em linhas gerais, a doutrina dissuasiva, esteja ela voltada para o uso de armamentos convencionais ou para o uso de armamentos nucleares, não foca a capacidade militar do inimigo, mas sua vontade de lutar. Mensurar a vontade de lutar do inimigo não é uma tarefa meramente técnica e passível de planejamento, como a destruição da capacidade militar, por exemplo. Portanto, face a esta dificuldade a doutrina dissuasiva costuma ser evitada pelos militares.

Doutrinas dissuasivas oferecem poucas oportunidades materiais às Forças Armadas, em parte porque elas são mais dependentes da vontade política do que da capacidade militar, em parte porque o objetivo da dissuasão é claro: punir o inimigo, o que abre pouco espaço à especialização técnica. Já as doutrinas ofensivas tendem a ser tecnicamente mais complexas e usualmente demandam mais pessoal. Portanto, a preferência das Forças Armadas por doutrinas ofensivas justifica-se também pelo poder que estas conferem à instituição.

Além de vantagens materiais, as doutrinas ofensivas asseguram aos militares um elevado grau de autonomia. De acordo com a literatura organizativista, a intervenção dos civis em questões operacionais é uma grande fonte de incerteza para as Forças Armadas. Doutrinas ofensivas costumam ser mais complicadas que doutrinas dissuasivas ou defensivas e campanhas ofensivas podem ser travadas fora do território nacional, logo elas são mais difíceis de serem compreendidas e controladas pelos civis.

A doutrina dissuasiva convencional é a que depende mais de apoio civil. A doutrina dissuasiva que propugna a resistência ao invasor, depende tão fortemente da legitimidade do governo e de sua autoridade sobre a 
população que é considerada a mais "política" das doutrinas. Por não serem tão complicadas como as doutrinas ofensivas e estarem tão sujeitas à cooperação com as autoridades civis quanto as doutrinas dissuasivas, as doutrinas defensivas também restringem a autonomia operacional dos militares. $^{24}$

Apoiando-se em eventos históricos, a teoria da organização sugere que a geografia influencia a escolha das doutrinas militares. Argumenta-se com freqüência que países circundados por vizinhos hostis e capacidade para deslocar suas tropas rapidamente de um front para o outro preferem doutrinas ofensivas. A Prússia e Israel são os casos mais citados para validar esta hipótese. Já as chances de aproveitar as condições geográficas para adotar uma doutrina defensiva, geralmente, são desperdiçadas pelos militares. Diante desta constatação, a literatura organizativista propõe que os fatores geográficos que sustentam a adoção de uma doutrina ofensiva são quase sempre utilizados ao passo que os fatores geográficos que sustentam a adoção de uma doutrina defensiva costumam ser ignorados pelas Forças Armadas (Posen, 1984:47-51).

Discutindo as razões que levaram três potências continentais como a França, a Alemanha e a Rússia a adotarem posturas ofensivas durante a Primeira Guerra Mundial, Jack Snyder reconhece a preponderância das características organizacionais das Forças Armadas na definição das estratégias militares ${ }^{25}$, mas rejeita a análise, às vezes mecanicista, da teoria da organização no que tange à preponderância da ofensiva. Segundo o autor, não é possível determinar uma única causa para a adoção de estratégias militares ofensivas pelas três potências continentais durante 0 conflito. Algumas causas desta preferência podem ter sido comuns a todos

\footnotetext{
${ }^{24}$ Segundo Posen (1984:50) a doutrina ofensiva torna os soldados especialistas em vitória, a defensiva os torna especialistas em atrito e a dissuasiva os torna especialistas em carnificina.

25 "In strategic policy making, the most pervasive source of motivational bias is the institutional interest of the military. The military tends to favor policies that promote its organizational aims. Since favored policies must be justified in strategic terms, strategic perceptions and analysis are likely to become skewed whenever organizational interests are at odds with sound strategy (Snyder, 1984:18)".
} 
os países, mas a fonte principal da escolha está na peculiaridade de cada caso:

In most cases, then, the choice between offensive and defensive strategies will be the result of some combination of rational incentives, motivational biases, and doctrinal oversimplifications. In particular circumstances (...) one or another of these determinants will dominate the decision maker's choice." (Snyder, 1984:19)

No que concerne à integração entre civis e militares, a teoria da organização argumenta que a própria natureza do Estado Moderno é um empecilho à atuação integrada dos especialistas responsáveis pela segurança estatal. Diplomatas e militares são funcionários públicos altamente especializados e esta especialização funcional característica do Estado Moderno faz com que os profissionais da diplomacia e especialmente os profissionais das armas desenvolvam habilidades e conhecimentos difíceis de serem compreendidos e compartilhados. A recíproca falta de conhecimento em relação aos problemas enfrentados por cada área e as barreiras impostas à coordenação das atividades tendem a levar a política exterior e a política de defesa à desintegração.

A literatura organizativista destaca ainda que a falta de integração entre a diplomacia e a política de defesa deve-se a três condutas recorrentes dos militares:

1. Por via de regra, as Forças Armadas não tomam a iniciativa de mudar os meios que pretendem empregar para atender as finalidades políticas do Estado. Freqüentemente, as forças militares evitam incorporar o calculo político na doutrina militar se entendem que isto interferirá nos aspectos técnicos das operações.

2. Os militares resistem em fornecer informações detalhadas sobre questões doutrinárias, especialmente aquelas que dizem respeito à condução das operações militares.

3. Sem interferência externa, ou melhor, civil, os militares não criam uma escala de prioridades que adeqüe a capacidade de cada Força e de cada Arma aos objetivos políticos do Estado. A tendência das organizações militares é dividir igualmente entre as Forças (e dentro de cada Força entre 
as Armas) os recursos financeiros destinados à Defesa Nacional. Somente as autoridades civis podem, de maneira isenta e tendo como referência a política de Defesa Nacional, definir quais Forças e Armas devem ser priorizadas. Caso os políticos civis se abstenham desta responsabilidade, cada Força Armada irá preparar-se para lutar sua própria guerra, sem cooperar efetivamente com as demais.

Analisando o que dificulta e o que motiva a inovação das doutrinas militares, a teoria da organização destaca que as Forças Armadas raramente promovem a inovação de suas doutrinas. Esta atitude deve-se à própria natureza da instituição, lembrando que para os organizativistas grandes organizações são avessas à mudança. O conservantismo das Forças Armadas levaria à rejeição das inovações devido ao grau de incerteza que este processo imprime à capacidade operacional da instituição. Em tempos de guerra, ter uma doutrina ruim é melhor do que não ter doutrina nenhuma.

As novas tecnologias são igualmente vistas com cautela pelas Forças Armadas, pois a eficácia de uma nova tecnologia militar só pode ser demonstrada em combate. São duas as exceções a esta regra:

1. Uma nova tecnologia pode ser testada numa guerra travada por outro Estado, militarmente dependente.

2. Os militares também podem testar uma nova tecnologia enquanto travam suas próprias batalhas.

Outra razão para as Forças Armadas decidirem inovar a doutrina militar é a derrota. Quando, numa guerra, os militares fracassam no cumprimento de sua missão, tendem a reexaminar a doutrina anteriormente adotada, antecipando-se desta forma às pressões dos políticos civis.

Mais uma vez, a teoria da organização enfatiza os aspectos positivos da intervenção civil nas questões militares. Se os civis não são tecnicamente capazes de elaborar uma nova doutrina militar, eles podem desempenhar um papel importante na definição de novas propostas. Direcionar mais recursos financeiros para uma determinada Força ou Arma é uma maneira eficaz de estimular a inovação uma vez que a competição 
por recursos fará com que as outras Forças também desenvolvam novas doutrinas a fim de conquistar a preferência das autoridades civis (Posen, 1984:52-57).

Em linhas gerais, a teoria da organização argumenta que as doutrinas militares tendem a ser ofensivas, carentes de integração com o poder civil, e estagnadas. Já a literatura neorealista, valoriza outros fatores na escolha e formatação de uma doutrina militar.

O neorealismo prediz atitudes mais heterogêneas dos Estados em relação à escolha das doutrinas militares. A preferência por uma doutrina dependerá da avaliação das condições políticas, econômicas, tecnológicas e geográficas de cada Estado, e levará em conta, principalmente, sua posição no sistema internacional.

O peso maior na definição das doutrinas militares recai, portanto, sobre a análise estatal acerca dos riscos e oportunidades oferecidas pelo sistema internacional, ficando as características organizacionais das Forças Armadas em segundo plano.

A autonomia dos militares na definição das doutrinas é possível apenas em condições especiais. Somente quando as ameaças à segurança do Estado são consideradas remotas, a dinâmica interna das instituições militares prevalece.

Segundo as premissas do neorealismo, as doutrinas ofensivas serão escolhidas por países que têm pretensões expansionistas. Os Estados que querem passar os custos da guerra para os inimigos também preferem as doutrinas ofensivas, pois elas permitem que as batalhas sejam travadas fora do território nacional.

As doutrinas ofensivas são igualmente preferidas por países que sentem sua posição ameaçada. Corridas armamentistas e mudanças previsíveis na configuração de poder na região podem levar um país a adotar uma doutrina ofensiva que permita atacar preventivamente 0 potencial inimigo. A guerra preventiva e, por conseguinte, uma doutrina ofensiva também é preferida por países que não contam com aliados e enfrentam múltiplas ameaças simultaneamente. 
Assim como os organizativistas, os neorealistas afirmam que Estados circundados por vizinhos hostis adotam com freqüência doutrinas ofensivas. $E$, às vezes, mesmo favorecidos por um ambiente pacífico e aliados, alguns Estados preferirão doutrinas ofensivas se seus aliados forem fracos. Adotando uma doutrina ofensiva, os diplomatas e militares tentam combinar a ameaça da aliança à ameaça do uso da força.

Por fim, os Estados responsáveis pela proteção militar de muitos aliados preferirão doutrinas ofensivas visto que elas possibilitam a concentração dos recursos militares destinados a cada país dependente.

Mas os Estados com grandes responsabilidades militares também podem decidir adotar doutrinas dissuasivas, de acordo com o neorealismo. $\mathrm{Na}$ impossibilidade de sustentar materialmente uma campanha ofensiva de grande porte e raio de ação, grandes potências podem optar, mesmo sem convicção, por uma doutrina dissuasiva.

Pelas mesmas razões os Estados pequenos ameaçados por uma grande potência optarão por uma doutrina dissuasiva. A coincidência na atitude de países muito fortes e muito fracos reside no caráter da doutrina dissuasiva. A dissuasão, como já foi dito anteriormente, é a mais "política" das doutrinas. Sua força está muito mais na coesão política do que em qualquer recurso material.

As doutrinas defensivas serão as preferidas dos países que estão se preparando para lutar em coalizão. Uma doutrina defensiva permite que os Estados da coalizão ganhem mais tempo para dividir os custos e os benefícios que a guerra pode trazer. Da mesma forma, esta doutrina é a favorita dos países que querem angariar aliados. Neste sentido, adotar uma doutrina defensiva é um sinal político, uma tentativa de aproximação.

Contrários ao que preconiza a teoria da organização, os neorealistas acreditam que os Estados que desejam apenas garantir sua integridade territorial adotarão doutrinas defensivas se as condições geográficas ou possibilidades tecnológicas tornarem este tipo de doutrina mais atrativa. Os países que planejam manter seu status quo também podem tomar a decisão de adotar uma doutrina defensiva por uma razão mais simples. 
Como é improvável que venham a desferir o primeiro ataque, estes países preferem aperfeiçoar a capacidade de responder eficazmente ao ataque dos possíveis inimigos (Posen, 1984:59-74).

Ainda no que diz respeito à relação entre tecnologia e doutrina militar, Stephen van Evera acrescenta que:

Technology and doctrine combined to define theses tides of offense and defense. Sometimes technology overrode doctrine, as in 1914-18 and in 1945-91 (when superpowers' militaries embraced offensive doctrines but could not find offensive counters to the nuclear revolution). Sometimes doctrine shaped technology, as 1939-45, when blitzkrieg doctrine fashioned armor technology into an offensive instrument (Evera, 1998:15).

Evera incorpora elementos cognitivos à sua análise. Para o autor, a percepção de um ambiente internacional favorável à guerra de conquista, pode acarretar as mesmas conseqüências que a possibilidade concreta desta forma de guerra, ou seja, se um determinado Estado acredita que a postura ofensiva é a mais adequada, adota-Ihe-a-rá ainda que esta atitude não tenha base na realidade. A teoria do ataque e defesa, prossegue Evera, tem duas variantes paralelas, uma real e outra perceptual, que devem ser consideradas conjuntamente (Evera, 1998: 02-03).

A teoria da organização identifica a intervenção civil como o fator mais importante para garantir a integração e a inovação das doutrinas militares, mas aponta que esta intervenção dificilmente ocorre. Já o neorealismo prediz que a intervenção civil ocorrerá sempre que a segurança do Estado estiver ameaçada.

Para os neorealistas, os políticos civis intervirão nas doutrinas militares sempre que tiverem ambições expansionistas em mente. Um ambiente internacional hostil é outra razão que induz a intervenção civil na doutrina militar. A percepção de insegurança igualmente torna os militares mais receptivos a sugestões vindas de fora da caserna. $O$ isolamento político, ou melhor, a falta de aliados também leva os dirigentes civis a prestarem mais atenção às suas Forças Armadas. 
As afirmações acima podem dar a impressão de que para os neorealistas a intervenção civil na doutrina militar ocorre somente quando o ambiente internacional é desfavorável. Contudo, outros motivos podem levar à interferência civil, como a experiência recente de um desastre militar ou a perspectiva de que uma determinada forma de guerra, ainda que vitoriosa, possa enfraquecer substancialmente o Estado em razão de seu alto custo.

Posen, entretanto, pondera que as hipóteses neorealistas apresentadas acima sobre a integração e inovação das doutrinas militares são mais apropriadas para um sistema bipolar. Num sistema multipolar, prossegue o autor, as alianças são voláteis e os políticos civis gastam mais tempo e energia procurando aliados do que controlando suas Forças Armadas (Posen, 1984:80).

\section{A crítica construtivista às abordagens neorealista e} organizativista

Elizabeth Kier, em Imagining War, aponta as limitações das abordagens teóricas anteriormente discutidas e defende que a formulação de doutrinas militares pode ser melhor compreendida a partir de uma perspectiva cultural.

Em primeiro lugar, a autora rejeita os principais pressupostos do realismo estrutural e do organizativismo, no que tange à adoção de doutrinas militares, a saber: (1) os interesses nacionais são autoexplicativos; (b) atores políticos do mesmo grupo sócio-econômico tendem a adotar as mesmas políticas em diferentes países (Kier, 1997:03).

Partindo desta crítica inicial, Kier elenca as limitações dos argumentos neorealistas e organizativistas para explicar por que um governo e suas Forças Armadas optam por uma doutrina militar.

No que diz respeito ao neorealismo, a autora questiona a tese de que são as mudanças na estrutura do sistema internacional que impulsionam as mudanças das doutrinas militares nacionais. Para tanto, 
Kier recorre a dois exemplos históricos. Em 1982, o Exército norteamericano decidiu mudar sua doutrina de combate aero-terrestre de defensiva para ofensiva sem que tivesse ocorrido nenhuma mudança estrutural no sistema internacional naquele período (Kier, 1997: 12). Se, sobre este episódio, os realistas podem responder que houve um reaquecimento da Guerra Fria com a chegada de Reagan ao poder, um outro exemplo, mais convincente, mostra a fragilidade do argumento realista. A Índia, que obteve sua independência do Reino Unido em 1947, só substituiu a doutrina militar herdada dos britânicos nos começo anos 80 (Kier, 1997:12).

Outro argumento realista questionado por Kier diz respeito ao papel dos civis na escolha das doutrinas militares. Para a autora, ao contrário do que acreditam os realistas, nem sempre os civis interferem na formulação das doutrinas militares quando a segurança do Estado está em risco, e ainda que os civis decidam participar da escolha doutrinal, isto não garante que esta atitude traga, necessariamente, resultados positivos.

A França no período entre-guerras é o exemplo utilizado por Kier para contrapor o argumento realista. Segundo a autora, os políticos franceses tentaram intervir na doutrina de suas Forças Armadas em meados da década de 1930, atitude esta contraproducente. Ao final da década, mesmo tendo informações de que Hitler estava se rearmando, não interferiram mais no assunto. Charles de Gaulle, que naquela época era coronel do Exército, buscou em vão apoio no parlamento francês para substituir a postura defensiva francesa por uma postura ofensiva. O Alto Comando do Exército resistiu à tentativa de interferência civil e ainda puniu o coronel De Gaulle, tirando-o da lista de promoções (Kier, 1997:13).

As críticas de Kier aos argumentos organizativistas estão relacionadas a duas idéias: (1) os militares escolhem a doutrina que melhor atenda seus interesses paroquiais; (2) as doutrinas ofensivas oferecem mais vantagens materiais e autonomia organizacional às Forças Armadas, por isso são sempre as preferidas dos fardados.

As escolhas doutrinais da Força Aérea e do Exército britânicos nas décadas de 1920 e 1930 contradizem os argumentos organizativistas, na 
visão de Kier. Durante o período citado, o Exército britânico tinha o menor contingente e o orçamento mais baixo entre as três Forças Armadas. Pela lógica organizativista, se o Exército britânico adotasse uma doutrina ofensiva poderia reverter esta situação desfavorável. Entretanto, não foi esta a opção adotada (Kier, 1997: 17).

A Força Área britânica também rejeitou os encantos da doutrina ofensiva. Se é verdade que os aviadores eram partidários do bombardeio estratégico, uma doutrina ofensiva, é igualmente verdade que a Força Aérea nunca utilizou esta preferência para obter vantagens materiais ou autonomia organizacional. Pelo contrário, após obter o status de Força Singular, os aviadores britânicos "ainda enamorados do bombardeio estratégico" passaram a trabalhar na construção de uma doutrina defensiva (Kier, 1997: 16).

Ademais, Kier acrescenta que uma doutrina defensiva também pode servir aos interesses paroquiais das Forças Armadas. Para preservar sua autonomia em relação aos políticos e à política, o Exército francês preferiu adotar uma doutrina militar defensiva na década de 1930 (Kier, 1997: 16).

A partir da decisão doutrinal do Exército francês, Kier expõe seu modelo explicativo. De acordo com a autora, os fatores determinantes na elaboração das doutrinas militares não são nem os constrangimentos externos do sistema internacional, nem os interesses paroquiais dos militares. O que melhor explica as decisões doutrinais da França e da GrãBretanha no período que antecedeu a Segunda Guerra Mundial é o contexto cultural dos dois países:

The choice between an offensive and a defensive military doctrine is best understood from a cultural perspective. Systemic imperatives are important to the development of doctrine, but conditions in the international system are not the sole or even the primary factor guiding civilian intervention. Instead, civilians' cultural understanding of the role of military force in the domestic arena governs their participation in developing doctrine. And because the military plays a pivotal role in building and maintaining the state, the domestic implications of military policy often shape civilian decisions. In designing military policy, civilians address their concerns about domestic threats and stability, 
such as whether the proposed military policy will threaten civilian control or the army's ability to execute its domestic responsibilities. However, once civilians reach a consensus about these issues, their decisions are more likely to correspond with systemic imperatives. Although civilian decisions set the framework for doctrinal developments, they rarely determine doctrine. Instead, the interaction between the constraints set in the domestic political arena and the military's organizational culture shapes the choice between offensive and defensive military doctrines. Understanding why military organizations behave differently requires an analysis of organizations' culture and how their basic assumptions, values, norms, beliefs, and formal knowledge shape the collective understandings of the organizations members. We cannot assume that most military organizations, most of the time, prefer offensive military doctrines; what the military perceives to be in its interest is a function of it is culture. However, the military's culture alone does not explain changes in the military doctrine; the military culture intervenes between civilian decisions and doctrinal choices (Kier, 1997:21). ${ }^{26}$

A chave a partir da qual é possível compreender a escolha de uma doutrina militar estaria situada, portanto, na co-relação de forças entre os atores políticos nacionais, que Kier denomina balanço de poder doméstico, e não na co-relação de forças entre os países. E as variáveis a serem observadas neste balanço de poder doméstico devem ser: a) as relações entre os civis e os militares; b) a maneira como esses atores interpretam o ambiente internacional; e c) a cultura organizacional das Forças Armadas.

Ainda que a autora não utilize o termo em seu livro, sem dúvida a explanação em torno das variáveis que compõe o balanço de poder doméstico remetem à discussão sobre cultura estratégica.

\section{Cultura estratégica: um conceito em construção}

O termo cultura estratégica foi utilizado pela primeira vez, em 1977, por Jack Snyder, num ensaio sobre a doutrina soviética de guerra nuclear limitada. Snyder usou o termo cultura estratégica para se referir a um conjunto de atitudes e crenças que guiam e circunscrevem o pensamento

\footnotetext{
${ }^{26}$ Kier (1996) apresenta este mesmo argumento em um artigo publicado na coletânea The Culture of National Security.
} 
sobre questões estratégicas, influenciam a maneira como estas questões são formuladas e articulam o vocabulário e os parâmetros perceptuais do debate estratégico (Johnston, 1995:05).

$\mathrm{Na}$ última década, Alastair I. Johnston fez uma revisão bibliográfica dos estudos que abordavam o pensamento estratégico a partir de uma perspectiva cultural e utilizou a metáfora das "três gerações" para categorizá-los de acordo com a proposta conceitual e metodológica adotada por seus autores.

A primeira geração de estudos sobre cultura estratégica dedicou-se primordialmente a explicar por que os governos soviético e norte-americano aparentemente pensavam de forma diferente a respeito da estratégia nuclear. Os autores da primeira geração atribuem as diferenças entre os países a variações em fatores tais como experiências históricas arraigadas, cultura política e geografia. De maneira geral, a interação entre estes fatores determinaria o comportamento dos países no âmbito estratégico.

Para Johnston as principais fragilidades teóricas da primeira geração são: a) o determinismo mecanicista ao tratar da relação entre cultura e comportamento, o que dificulta a avaliação da relevância causal da cultura estratégica, e b) a forma simplista como a cultura estratégica nacional é definida, excluindo a possibilidade da existência de mais de uma cultura estratégica em um mesmo país (Johnston, 1995:37-39).

A segunda geração de estudos sobre cultura estratégica rejeita o determinismo mecanicista de seus predecessores no que concerne à relação entre cultura e comportamento. Os autores desta geração partem da premissa de que há uma grande diferença entre a política declaratória, ou seja, o que os líderes políticos pensam ou dizem que estão fazendo, e os verdadeiros motivos pelos quais os políticos adotam determinadas posturas. Neste sentido, a cultura estratégica é vista como um instrumento dos grupos políticos hegemônicos uma vez que o discurso oficial dos formuladores de política militar camuflaria os verdadeiros motivos pelos quais este discurso é produzido, qual seja, defender os interesses particulares destes formuladores. Johnston reconhece o avanço teórico da segunda geração, que inova ao mostrar a disjunção entre a cultura 
estratégica ou discurso simbólico e o comportamento político, mas aponta alguns problemas metodológicos nesta abordagem.

Primeiramente, os estudos da segunda geração não esclarecem como a cultura estratégica pode influenciar o comportamento dos formuladores de política, pois se a Política de Defesa Nacional de um país é reflexo dos interesses particulares dos grupos que a formulam, qual é o papel da cultura estratégica neste processo? Neste caso, pode-se argumentar que a Política de Defesa Nacional é determinada, em última instância, pelos interesses e não pela cultura estratégica. Uma explicação que um analista realista aceitaria sem maiores questionamentos.

A segunda geração também não responde satisfatoriamente por que os países adotam posturas estratégicas diferentes ou semelhantes. Podese argumentar que o discurso simbólico de um grupo de formuladores de política legitima certas opções estratégicas e deslegitima outras. As opções estratégicas legítimas ou ilegítimas variariam então de acordo com a cultura estratégica de cada país. Mas como explicar que países com culturas estratégicas diferentes compartilhem opções estratégicas semelhantes (Johnston, 1995:39-41)?

Já a terceira geração de estudos sobre cultura estratégica, na qual Johnston e Kier se incluem, busca um maior rigor metodológico. Em sua maioria, os autores da terceira geração se esforçam para elaborar um conceito de cultura estratégica que possa testado através de uma metodologia positivista. Nesta perspectiva a cultura é vista como uma variável independente e o comportamento político como uma variável dependente. Johnston define da seguinte forma o conceito de cultura estratégica:

Let me suggest that strategic culture as a "system of symbols" comprises two parts: the first consists of basic assumptions about the orderliness of the strategic environment - that is, about the role of war in the human affairs (i.e., whether it is aberrant or inevitable), about the nature of the adversary and the threat it poses (i.e., zero-sum or positive sum), and about the efficacy of the use of force (i.e., about the ability to control outcomes and eliminate threats and the conditions under which the use of force is useful). Together these comprise the central 
paradigm of a strategic culture. Note the parallels with the core assumptions embodied in traditional definitions of political culture.

The second part of strategic culture consists of assumptions at a more operational level about what strategic options are the most efficacious for dealing with the threat environment as defined by answers to these three sets of questions. These lower-level assumptions should flow logically from the central paradigm. It is at this second level that strategic culture begins to impact directly on behavioural choices. Thus the essential components or empirical referents of a strategic culture will appear in the form of a limited, ranked set of grand strategic preferences that are consistent across the objects of analysis and persistent across time. They are not, therefore, necessarily responsive to changes in noncultural variables such as technology, threat, or organization (Johnston, 1995:37-38). ${ }^{27}$

Neumann e Heikka são perspicazes quando afirmam que a metáfora das três gerações criada por Johnston acabou por voltar-se contra o seu próprio criador, já que "é raro um neto herdar todas as virtudes dos seus predecessores e nenhum dos seus defeitos (Neumann e Heikka, 2005:09)". Para os autores, o principal "defeito" herdado por Johnston da primeira geração é a decisão de utilizar uma metodologia positivista quando os antropólogos e sociólogos há tempos encaram a cultura como fenômeno constitutivo e não uma variável independente que pode ser isolada (Neumann e Heikka, 2005:09).

Esta crítica é reiterada por Jack Snyder que analisou uma série de estudos etnográficos sobre guerras em sociedades sem Estado e constatou que a cultura como variável independente não é capaz de explicar os conflitos armados por ele selecionados. Snyder defende uma análise que leve em conta a interação entre as variáveis materiais, institucionais e culturais (Snyder, 2003).

Para superar as limitações metodológicas da terceira geração, Neumann e Heikka propõem um conceito de cultura estratégica que leve em conta o seu caráter constitutivo:

Strategic Culture Understood as Transnationally Nested Dynamic

27 Johnston (1996: 223) apresenta uma versão um pouco modificada do seu conceito de cultura estratégica em artigo publicado na coletânea The Culture of National Security. 
Interplay between Grand Strategy Understood as a System for Formation of Statements and the Practices of Doctrines, Civil-Military Relations and Procurement (Neumann e Heikka, 2005:18).

O conceito de cultura estratégica proposto por Neumann e Heikka leva em conta as interconexões entre o contexto internacional e a dinâmica doméstica, definida pelos atores políticos e suas práticas e nos parece mais apropriado para lidar com o caso brasileiro, pois acreditamos como Sahlins (1990) que uma questão, independentemente de sua natureza, só adquire sentido para um grupo social à medida que este grupo faça uma "reavaliação funcional das categoriais" a partir das quais pensará sobre esta questão.

Posto de outra forma, uma questão só faz sentido para um grupo social quando é apropriada e interpretada por este grupo em seus próprios termos. Esta interpretação é invariavelmente mediada por categorias endógenas.

Por exemplo, quando os militares brasileiros pensam sobre a Amazônia, fazem-no condicionados por um repertório de experiências históricas das Forças Armadas na região. Estas experiências históricas, por sua vez, são pautadas pela cultura estratégica dos militares. Em suma, a cultura estratégica de um grupo social é moldada pela prática de seus membros bem como a prática dos membros de um grupo social é moldada pela cultura estratégica desse grupo.

Em vista disto, nos próximos capítulos analisaremos como os militares brasileiros - atores políticos preponderantes na formulação da Política de Defesa Nacional - constroem suas percepções e estratégias para a região amazônica. 


\section{CAPÍTULO II}

\section{A REPRESENTAÇÃO DA AMAZÔNIA NO DISCURSO MILITAR}

\section{Linhas gerais do pensamento militar sobre a Amazônia}

Na visão das Forças Armadas, e de seus intelectuais militares, a Amazônia representa a última fronteira a ser conquistada e incorporada ao Estado brasileiro. Esta percepção está presente em entrevista concedida pelo ex-ministro do Exército Zenildo Lucena em 1998:

A Amazônia representa a última fronteira de nosso território, a maior reserva mundial de floresta tropical, um patrimônio herdado do sacrifício de nossos antepassados. Impõe-se-nos, assim, o dever de preservá-la e desenvolvê-la para os brasileiros do futuro (Lucena, 1998).

Suas riquezas naturais causam admiração e temor. Admiração porque estas riquezas, caso sejam exploradas pelos brasileiros, podem contribuir para o fortalecimento do poder estatal, e temor porque estas riquezas naturais também são cobiçadas pelos países industrializados.

A idéia de que a Amazônia é cobiçada pelos estrangeiros não foi criada pelos militares $^{28}$, mas desempenha um papel vital na construção do imaginário das Forças Armadas sobre a região, influindo decisivamente no sentido que seus oficiais atribuem à missão na região. No trecho abaixo, a divisa "A selva nos une", é representativa do papel agregador desempenhado pela Amazônia no imaginário militar:

Ao guardar a mais cobiçada porção de nosso território e contribuir para o seu desenvolvimento, o Comando Militar da Amazônia atua para

\footnotetext{
${ }^{28}$ A idéia de que a Amazônia é cobiçada pelos estrangeiros circula nos bastidores políticos brasileiros desde a época em que suas fronteiras foram definidas. João Roberto Martins (2003) relembra uma série de comissões parlamentares criadas ao longo do século XX para investigar a presença de estrangeiros na Amazônia no artigo $A$ visão militar sobre as novas ameaças na Amazônia brasileira.
} 
impedir que a soberania brasileira na região seja maculada por objetivos escusos, volta e meia propalados no seio da opinião pública internacional. No cumprimento de tão nobres missões, a cada dia faz soar a quantos possam ouvir que "A selva nos une; a Amazônia nos pertence" (Verde Oliva, 2002).

A extensão territorial da Amazônia também é vista com reverência pelos militares. Uma frase do general Rodrigo Octávio Jordão Ramos, primeiro Comandante Militar da Amazônia em Manaus ${ }^{29}$, exprime com propriedade o sentimento dos militares sobre o território amazônico:

Árdua é a missão de defender e desenvolver a Amazônia. Muito mais árdua, porém, foi a de nossos antepassados em conquistá-la e mantêla (Exército Brasileiro, 2007a).

$\mathrm{Na}$ frase acima é possível identificar o orgulho dos militares por terem "herdado" dos portugueses o imenso território amazônico, assim como a percepção de que a missão de defendê-lo é hercúlea, logo, merecedora da mesma reverência que os militares prestam aos colonizadores portugueses. A admiração dos militares brasileiros pelos feitos de Portugal na América não se limita à extensão de terras conquistadas pelos lusitanos. No cerne do ideário militar sobre a defesa da Amazônia, reside a crença de que a soberania brasileira sobre a região pode ser garantida somente através de sua colonização. Esta crença assenta-se na estratégia adotada pela Coroa Portuguesa, e, posteriormente, pelo Império para expandir e manter o território que hoje pertence ao Brasil.

A percepção dos militares brasileiros acerca do colonizador português merece algumas considerações. Nelson Werneck Sodré mostra a persistência da estrutura militar colonial na nascente estrutura militar do Império brasileiro em sua História Militar do Brasil:

A Constituição de 1824 procurou definir as linhas gerais da estrutura militar oficial, obedecendo aos moldes coloniais que haviam estabelecido a três linhas: a primeira, composta da tropa regular e

${ }^{29}$ O Comando Militar da Amazônia foi criado em substituição ao Grupamento de Elementos de Fronteira de Belém e foi transferido para Manaus em 1969 (Exército Brasileiro, 2007b). 
paga; a segunda e a terceira, compostas de milícias e ordenanças, simplesmente auxiliares e gratuitas. Daí as três categorias militares, exército, milícias e guardas policiais, com efetivo fixado anualmente e, ainda fixado anualmente $\mathrm{o}$ processo de recrutamento. $O$ exército destinava-se a defender as fronteiras e nelas estacionar; as milícias incumbiam-se de manter a ordem pública nas comarcas, dentro de cujos limites permaneceriam, sendo eletivos e temporários os seus oficiais, a exceção dos majores e ajudantes; as guardas policiais eram encarregadas de fornecer a segurança dos indivíduos, perseguindo e prendendo os criminosos. Só em casos de rebelião ou invasão estrangeira poderia o governo desviar tais tropas de seu mister privativo, submetendo ao exame da Assembléia Geral, porém, as circunstâncias determinantes. As deficiências dessa organização saltavam aos olhos e estavam ligadas ao desejo de acomodar-se aos modelos coloniais (Sodré, 1968:87).

Mas a persistência das tradições portuguesas na estrutura militar brasileira não se limita à configuração organizacional das forças de segurança no Brasil imperial, tal como Sodré descreve na citação acima. Ela evidencia-se de forma marcante na configuração da identidade institucional das Forças Armadas brasileiras. A linearidade presente no discurso militar - que vê sua atuação na Amazônia como continuação do papel desempenhado pelos colonizadores portugueses na região - mostra que os militares brasileiros não identificam o colonizador português como seu antípoda, um sentimento comum a forças militares criadas a partir de um processo de independência, mas reverenciam-no como seu antecessor.

Associada à crença de que a defesa da Amazônia só pode ser garantida através de sua colonização, surge a idéia de que a região corre risco por ser um grande vazio demográfico:

Portanto, o problema amazônico é sem dúvida alguma para a consciência nacional uma questão de primordial importância para o Desenvolvimento e a Segurança (...) salienta não admitir na vida econômica do presente "espaços vazios" diante da explosão demográfica existente no mundo atual, com profundo agravamento no futuro. Devemos, pois, atentar profundamente na séria advertência feita por Bismark: "As riquezas naturais, nas mãos de quem não sabe ou não as quer explorar, constituem permanentemente perigo para quem as possui (Cruz, 1975:08)". 
A representação da Amazônia como um grande vazio demográfico, pode ser encontrada nos estudos de geopolítica que foram produzidos entre as décadas de 1930 e $1980 .{ }^{30}$ Influenciados por uma escola geopolítica que considerava a população como um dos instrumentos de poder dos estados ${ }^{31}$, os estudiosos brasileiros, majoritariamente militares, detectavam na baixa densidade demográfica da região amazônica, um fator de risco à soberania nacional.

Para além da matemática ${ }^{32}$, outras variáveis interferem na identificação da Amazônia como um vazio demográfico. A região não é considerada um vazio demográfico apenas por ser despovoada no sentido estrito da palavra, mas por ser povoada, principalmente, por comunidades indígenas. Neste sentido, o vazio a que se referem os estudos que consolidaram esta visão sobre o espaço amazônico, é o vazio de uma população comprometida com a preservação da soberania brasileira sobre a região.

A percepção de que os povos indígenas que vivem na Amazônia podem ser cooptados por estrangeiros é uma constante no discurso militar como mostra Karenina V. Andrade (2003:86). Esta percepção, mais uma vez, deriva do vínculo estabelecido entre os militares brasileiros e o colonizador português. Rememorando as dificuldades encontradas pelos antecessores portugueses para assegurar a soberania sobre a Amazônia, os fardados temem que os indígenas contemporâneos ajam como alguns de seus antepassados que, num passado longínquo, aliaram-se a ingleses, holandeses e franceses que pretendiam conquistar terras na região. Eles temem igualmente uma reedição da aliança entre os indígenas e atores não-estatais que pretendem mudar a ordem política na região, como a estabelecida entre os Mura e os revoltosos cabanos no Império. Esta

${ }^{30}$ De acordo com Eugênio Diniz Costa (1994:63), à exceção do general Meira Mattos, que escreve sobre a Amazônia no início da década de 1980, os outros geopolíticos que estudam a Amazônia identificam a região como vazio demográfico.

${ }^{31}$ Shiguenoli Miyamoto (1995) discute detalhadamente a bibliografia geopolítica produzida no Brasil até a década de 1980 em seu livro Geopolítica e poder no Brasil.

${ }^{32}$ A densidade demográfica da Amazônia é aferida dividindo-se o total da população pela área total da Amazônia Legal. 
preocupação é expressa pelo especialista em História Militar do Exército, Cláudio Moreira Bento:

A revolta da Cabanagem e a impunidade de seus adeptos foi motivada pela ausência do Estado na imensa área amazônica. Poderia ser vitoriosa, perdendo o Brasil nesse, o domínio da foz do Amazonas, pela interferência francesa a partir do Amapá, se maior capacidade intelectual, militar e política tivessem tido suas lideranças. Ela ameaçou seriamente a unidade do Brasil na Regência (Bento, 2001:135).

Desde a década de 1980, o principal foco de divergência entre os fardados e os nativos é a demarcação de reservas indígenas. Os militares não são totalmente contrários à concessão de áreas para a criação de terras indígenas, mas questionam com freqüência a chamada demarcação em área contínua. Os principais argumentos dos fardados para se contrapor a este tipo de demarcação são a extensão das terras reivindicadas, sua localização, já que algumas das reservas demarcadas estão próximas à faixa de fronteira, e a possibilidade dessas terras se tornarem o embrião de um estado autônomo. As riquezas existentes no subsolo das terras reivindicadas também são citadas com freqüência como argumento em favor da revisão das demarcações em área contínua já homologadas $^{33}$.

Os militares rejeitam as justificativas apresentadas pelas lideranças indígenas e seus apoiadores de que a extensão de terras reivindicadas para as reservas é necessária para garantir a sobrevivência física e cultural dos povos indígenas. Na percepção castrense o "isolamento" dos nativos é prejudicial ao país e aos próprios indígenas que estariam sendo privados das benesses da civilização, tais como a educação formal e a medicina tradicional (Vidigal, 2002:95-96).

Apesar da oposição ferrenha dos militares à política de criação de reservas em área contínua, pode-se afirmar que o sentimento de desconfiança dos militares em relação aos indígenas está diminuindo

${ }^{33}$ Consolidou-se no imaginário militar a idéia de que os missionários começaram a lutar pela demarcação de reservas depois que as pesquisas geológicas do projeto Radam (Radar da Amazônia) detectaram a existência de minerais valiosos nas terras tradicionalmente ocupadas pelos índios. 
paulatinamente, bem como a representação do índio como ser inferior que não tem condições de defender a Amazônia. Contudo, estas mudanças são mais perceptíveis quando analisamos, por exemplo, a relação do Exército com os soldados de origem indígena do que quando nos detemos na análise do discurso militar. O depoimento de um oficial general que serve na Amazônia num seminário realizado no Ministério da Defesa, em novembro de $2005^{34}$, exemplifica a complexa dinâmica da relação entre o Exército e os indígenas. Referindo-se ao papel humanitário desempenhado pelo Exército nas terras indígenas, o general Gabriel ${ }^{35}$ relatou alguns hábitos considerados por ele pouco "civilizados" das índias parturientes na região de São Gabriel da Cachoeira (AM) e o esforço dos médicos da Força para mudá-los.

Por que o general se referiu às índias de forma tão negativa? Pois, se por um lado, o discurso do general sobre as parturientes é eivado de preconceito, por outro lado, a atuação do Exército nas terras indígenas, com algumas exceções, tem sido bem avaliada pelo governo, parlamento e, inclusive, setores da sociedade civil historicamente refratários à presença militar em áreas demarcadas. ${ }^{36}$ Alguns depoimentos concedidos por exComandantes Militares da Amazônia a Celso Castro podem nos ajudar na compreensão desta postura dicotômica do Exército. No artigo Os militares e os outros Castro aponta um traço característico do discurso militar sobre a

${ }^{34}$ O seminário citado é o: Defesa Nacional em Debate: Amazônia, realizado pela Secretaria de Estudos e Cooperação do Ministério da Defesa nos dias 30 de novembro e 01 de dezembro de 2005. Presenciei a fala reproduzida acima durante o evento e considerei-a "boa para pensar", parafraseando Lévi-Strauss.

${ }^{35}$ Nome fictício.

${ }^{36}$ A contenda em torno da instalação do $6^{\circ}$ Pelotão Especial de Fronteira em Uiramutã, município que fica no interior da reserva Raposa Serra do Sol, é um exemplo da relação tensa entre o Exército e os indígenas. A antropóloga Roberta Mélega (2007) também relata uma disputa entre o Exército e os ianomâmis acerca da construção de uma estrada ligando o $5^{\circ}$ Pelotão Especial de Fronteira de Maturacá a São Gabriel. Já os artigos de Beatriz de Almeida Matos (2006) e (2007) e Hilton S. Nascimento (2007) do Centro de Trabalho Indigenista que abordam a relação entre os militares e os Mayoruna que vivem na fronteira com o Peru, apontam uma mudança positiva no relacionamento entre os fardados e os indígenas. 
Amazônia. Num primeiro momento, a fala dos generais tende a homogeneizar o comportamento dos civis na região amazônica e adjetivá-lo negativamente. Porém, quando os generais individualizam alguns setores civis, esta visão negativa ganha nuances (Castro, 2003:04).

Voltando à fala do general Gabriel no Ministério da Defesa, acredito que podemos inseri-la na dinâmica identificada por Castro. As índias parturientes, tomadas como representantes de um todo - "os índios" - são retratadas de forma negativa, porque, na fala do militar, elas servem de contraponto aos médicos do hospital militar, cuja missão é enaltecida pelo depoente ${ }^{37}$. Porém, quando são citados em outro contexto, os indígenas podem ser retratados de forma positiva. Os índios que servem nos Pelotões Especiais de Fronteira, por exemplo, são tratados pelo general como valorosos soldados. Neste sentido, o discurso do Exército sobre os indígenas repete o mesmo padrão percebido no discurso da instituição sobre os civis. Quando tomados como representantes de uma categoria que, por alguma razão, contrapõe-se aos militares, os índios, os civis e outros atores políticos recebem uma conotação negativa. À medida que estas categorias são adjetivadas, ou seja, à medida que os "índios" passam a ser diferenciados como soldados índios ou ianomâmis que ocupam uma extensa faixa de terra na fronteira, as nuances aparecem.

A desconfiança dos fardados em relação aos indígenas remete a outro ponto central do discurso militar sobre a Amazônia: a presença e o papel dos atores não-estatais na região. Desde o período colonial, os representantes do poder estatal na Amazônia convivem com atores políticos que não são leais a nenhum Estado em particular. Esta convivência foi pacífica, na maior parte do tempo, com algumas exceções.

As ordens religiosas católicas, por exemplo, atuaram como parceiras da Coroa portuguesa na Amazônia por um século, entre meados do século

${ }^{37}$ Em outro trabalho, Castro (2004) examina o processo de construção da identidade militar na academia que forma os oficiais do Exército brasileiro e aponta que, num primeiro momento, o cadete constrói sua identidade militar diferenciando-se dos civis. Acredito que este recurso de afirmação pela diferenciação é utilizado pelos militares das três Forças quando abordados sobre o papel que desempenham na Amazônia. 
XVII e a expulsão dos jesuítas em 1759 (Castro e Souza, 2006: 59). Durante o século $\mathrm{XX}$, os salesianos repetiram a parceria com o Estado na Amazônia. Atuando no Rio Negro desde 1910, a missão salesiana só perdeu importância na década de 1980, quando o Exército ampliou sua presença na área (Peres, 200:55). No âmago das divergências que resultaram na expulsão dos jesuítas no setecentos ${ }^{38}$ e no rompimento das relações amistosas entre os militares brasileiros e os religiosos no final do século XX, está a política destes atores para os povos indígenas.

A criação do Conselho Indigenista Missionário (CIMI), em 1972, marca a inflexão da política católica para as comunidades indígenas e o início das desavenças entre missionários católicos e militares na Amazônia. Até a década de 1970, os militares e os religiosos católicos trabalhavam conjuntamente no sentido de "integrar" o índio à sociedade brasileira, compelindo-o a abandonar sua cultura e incorporar os costumes, a organização social, a língua, as crenças e as tradições do "civilizador" branco. Porém esta parceria inviabilizou-se quando os católicos começaram a trabalhar em favor da preservação da cultura indígena. Dois trechos escritos por coronéis aviadores que serviram na Amazônia durante a década de 1970 exprimem com primor a parceira entre militares e missionários:

Certa vez, quando passávamos pela missão Cururu, próxima à fronteira do Pará com Mato Grosso, às margens do rio desse nome, fundada e ainda dirigida por missionários alemães, ouvimos de uma freira idosa a revelação de que antes do advento do Correio Aéreo da Amazônia, aquela missão passava por necessidades agudas. Em algumas épocas passavam por ali apenas dois ou três regatões por ano. Citou que o pioneiro e fundador da missão, o nosso querido e estimado frei Plácido, que dedicou toda a sua vida àquela missão e ao aculturamento dos seus índios (...) passou dias difíceis com alguns companheiros de então (Pliopas, 1975:22).

A FAB tem trabalhado em conjunto com os missionários nas áreas de fronteiras habitadas por índios. Esta experiência tem dado excelentes resultados porque é baseada em um tríplice relacionamento cujos interesses são mutuamente satisfeitos: os índios recebem apoio dos

${ }^{38}$ Sobre a expulsão dos jesuítas no período pombalino ver: Farage (1991). 
missionários e da FAB. Os missionários cumprem a sua missão de catequese aos índios, recebendo ajuda da FAB. Esta, por sua vez, fica satisfeita com a segurança daquela área de fronteira face à presença da missão religiosa, ensinando a nossa língua aos índios que, certamente, ficarão do nosso lado (Guimarães, 1980:16).

Se a relação entre os militares e a Igreja católica pode ser considerada pendular, a convivência entre os fardados e os missionários protestantes nunca foi amistosa. Vistos como agentes estrangeiros a serviço dos seus países de origem, os protestantes foram colocados sob suspeita desde que estabeleceram suas primeiras missões na Amazônia no início do século XX (Destro, 2006:37).

É importante ressaltar que não são somente os militares que vêem com desconfiança a presença de missões protestantes na Amazônia. Os membros do Conselho Indigenista Missionário também criticam veementemente a atuação de algumas dessas missões:

Por outro lado, vemos se expandir na região um fenômeno de 'neocolonialismo religioso', que avança sobre os povos indígenas através de igrejas fundamentalistas - MEVA, Novas Tribos e outras (Heck, 2000:96).

Além dos missionários, outras categorias de atores não-estatais estão representadas no discurso castrense acerca da região amazônica. Os atores não-estatais, de acordo com Rafael Villa, distinguem-se em função de seus objetivos e de sua atuação. Existem os atores transnacionais não públicos que atuam a partir de uma base territorial, apesar de não se aterem a elas, desenvolvem sua ação coletiva fora das arenas públicas internacionais e não respeitam as normas de direito nacional ou internacional. Estes atores são uma força desagregadora que torna a ordem internacional mais instável, já que suas ações são imprevisíveis. E existem também os atores transnacionais públicos nãoestatais que, ao contrário dos primeiros, agem como força centrípeta, pois utilizam mecanismos de atuação política ou jurídica, congruentes com os das esferas públicas nacionais. Estes atores não são concorrentes antinômicos do Estado e, muitas vezes, estabelecem alianças com atores estatais. Entretanto, não dependem do Estado para subsistir. A principal 
característica dos atores transnacionais públicos é a flexibilidade com a qual atuam na esfera governamental e intergovernamental (Villa, 2004:2025).

Os contrabandistas ${ }^{39}$ e os traficantes de drogas encaixam-se na primeira tipologia apresentada por Villa, as missões religiosas e as ONGs encaixam-se na segunda. Já as guerrilhas existentes nos países amazônicos, a rigor, não pertencem a nenhuma das duas tipologias apresentadas acima, pois se trata de atores não-estatais que lutam para se tornar um ator estatal. Contudo, na percepção dos militares brasileiros as guerrilhas encaixam-se no perfil de atores transnacionais não públicos. Esta visão cristalizou-se sobretudo após os atentados de 11 de setembro de 2001 nos Estados Unidos, já que a partir deste evento a política de segurança norte-americana passou a priorizar o combate ao terrorismo internacional. Neste novo contexto, as guerrilhas colombianas são consideradas organizações terroristas pelo governo norte-americano.

No discurso do Exército, a presença de atores não-estatais na Amazônia é vista como um entrave à manutenção da soberania brasileira sobre a região. Dentro desta perspectiva, as missões religiosas e as ONGs que militam em favor da defesa dos direitos indígenas e da preservação do meio ambiente, estariam contribuindo indiretamente para a desnacionalização da Amazônia, pois suas denúncias podem ser utilizadas como pretexto para que os países industrializados que cobiçariam a Amazônia há séculos intervenham militarmente na região.

A presença de guerrilhas, contrabandistas e traficantes de drogas no espaço amazônico também contribuiriam indiretamente para a desnacionalização da área porque denotariam que o Estado brasileiro não é capaz de controlar uma vasta parcela de seu próprio território (Vidigal, 2002:97).

A instabilidade política nos países situados nas fronteiras oeste e norte do Brasil, a emergência nesses Estados de líderes políticos que se apresentem como antípodas do governo norte-americano, e os possíveis

\footnotetext{
${ }^{39}$ Refiro-me aos contrabandistas de madeira, minerais e armas, além da biopirataria.
} 
litígios fronteiriços envolvendo vizinhos que compõe o arco amazônico também são temas recorrentes no discurso militar sobre a Amazônia ${ }^{40}$. No que diz respeito ao último tema citado, a conflagração de um conflito nos lindes do território nacional, levaria o Brasil a se envolver indiretamente na guerra. Nesta hipótese, as Forças Armadas podem ser acionadas para garantir um cessar fogo, um papel que os fardados já desempenharam na Missão de Observadores Militares no Equador - Peru (MOMEP) entre 1995 e 1999.

Porém, o que de fato preocupa os militares brasileiros na hipótese de uma guerra na Amazônia não é tanto a/uma missão de pacificação que eles provavelmente assumirão, mas a necessidade de garantir a inviolabilidade do território nacional. Os problemas fronteiriços entre a Venezuela e a Guiana ocupam um lugar de destaque no imaginário militar a este respeito:
A efetiva atuação do Exército e da $F A B$ proporcionará segurança e desenvolvimento na fronteira. Evitaremos as atenções internacionais (...) sentimos agravarem-se entre a Venezuela e a Guiana problemas de fronteira mal conduzidos em 1902 (...) Em 1968, insinuações do representante da Guiana que afirmava pretensões venezuelanas em 2/3 do seu território. O Ministro das Relações Exteriores da Venezuela, Ignácio Irrabarren Borges protestou, contra-afirmando que a Venezuela é que se sentia lesada em 1/7 de seu território. Uma provável disputa militar implicaria em cruzamento de terras brasileiras (...) As Forças Armadas precisam estar preparadas na fronteira norte para mantermos inviolável o solo pátrio (Aildon Dornellas de Carvalho, 1975: 32-33).

Os fardados enfatizam que somente a presença militar na Amazônia brasileira pode impedir que a região venha a ser utilizada como rota pelos beligerantes para chegar à zona em litígio. Em suma, no imaginário militar a incursão de forças beligerantes na porção brasileira da Amazônia (assim como a presença de atores transnacionais não públicos) pode ser interpretada como sinal de que o Brasil é incapaz de controlar seu próprio território, despertando a antiga cobiça internacional pela área.

\footnotetext{
${ }^{40} \mathrm{Na}$ exposição de motivos apresentada pela Secretaria Geral do Conselho de Segurança Nacional ao presidente José Sarney, que resultou na criação do Programa Calha Norte, estes temas são apontados como fatores que podem vir a ameaçar a soberania brasileira sobre a Amazônia. Costa (1994) e Nascimento (2005) analisam o Programa Calha Norte.
} 
A emergência de lideranças políticas que se contrapõem veementemente às diretrizes estadunidenses para a América do Sul também causa espécie na caserna ${ }^{41}$. Na época da Guerra Fria, a existência de um governo hostil a Washington na América do Sul era interpretada, grosso modo, como uma tentativa de infiltração do "movimento comunista internacional" numa área de influência norte-americana, o que poderia justificar uma intervenção militar dos Estados Unidos. No pós-Guerra Fria este tipo de liderança continua a preocupar a caserna por motivos diversos que serão expostos no próximo capítulo.

Em linhas gerais, o discurso militar sobre a Amazônia articula-se em torno dos temas tratados nesta seção. A percepção de que a soberania brasileira sobre a região está ameaçada, conforme foi exposto, não é recente e nem pode ser reduzida a uma mera resposta dos militares brasileiros aos constrangimentos impostos pelo sistema internacional.

Abaixo transcreveremos dois trechos de depoimentos escritos por oficiais do Exército acerca da região amazônica. O primeiro trecho foi redigido em 1971 pelo então capitão Marseno Alvim Martins na apresentação do livro Amazônia e nós, no qual o militar narra sua experiência no $5^{\circ}$ Batalhão de Engenharia de Construção em Rondônia:

Talvez não haja no mundo uma área tão paradoxal como a Amazônia. Foi durante muitos séculos, proporcionalmente a mais esquecida parte da Federação; hoje é possivelmente, a mais lembrada. Para uns é um inferno, para outros é um céu de esperanças (...) Quase todos a cobiçam, todavia poucos a entendem. Pacata e tranqüila, ela continua a desafiar-nos. Até quando? Nos dias atuais, quando o mundo vive uma fase tecnológica das mais ousadas, prenunciando-se já a conquista do espaço sideral, a Amazônia vive novamente um drama dos mais paradoxais (...) vive problemas que pouco diferem de quando o País foi descoberto há 469 anos: o índio, dificuldades mesológicas, baixíssima densidade demográfica, deficiência de comunicações, etc. Sua potencialidade geo-econômica é soberba. Não erraríamos se disséssemos que suas riquezas são incalculáveis. Entretanto, ao lado desse panorama incentivador, aparecem

\footnotetext{
${ }^{41}$ Quando a exposição de motivos que deu origem ao Programa Calha Norte foi elaborada, temia-se que a Guiana e o Suriname, países recém-independentes, fossem atraídos à esfera de influência cubana (Denys, 1998).
} 
os primeiros grandes obstáculos: Como conquistá-la? Quanto tempo levaremos para fazê-lo? (...) Mas todas essas especulações surgem de um estímulo tentador que nos orgulha sobremaneira: a Amazônia é a mais pura, a mais bonita, a mais promissora e a mais rica região do globo terrestre, dentro dos chamados "grandes vazios" (Martins, 1971:13-14).

O segundo trecho está na orelha do romance "baseado em fatos reais" escrito em 2003 pelo general Moacyr Barcellos Potyguara sobre o cotidiano de um Pelotão Especial de Fronteira na fictícia Curi-Curi, localizada na fronteira com a Colômbia. A história se passa em 1966:

O Brasil é um país cujo território ocupa aproximadamente $50 \%$ da área da América do Sul. Suas fronteiras terrestres, com uma extensão de cerca de 17 mil quilômetros, requerem a presença física da população, a fim de manter sua integridade, e essa presença é feita, prioritariamente, com organizações militares do Exército distribuídas desde o Chuí até o Oiapoque. A fronteira amazônica é uma região inóspita, selvagem e cuja integração é obtida com a abnegada presença desses brasileiros, transportando para aqueles rincões os costumes e o uso da língua, importantes para a constituição da nacionalidade. Pelotão de Fronteira é uma obra que relata, em linguagem amazônica, as delícias e as agruras, a rotina e o pitoresco do viver na floresta, marcando os limites do Brasil (Potyguara, 2003: s/n).

No primeiro trecho encontramos alguns temas recorrentes no discurso militar que foram abordados nessa seção: as riquezas naturais, a cobiça internacional, os índios e o vazio demográfico. No segundo trecho percebe-se que a representação da Amazônia como "última fronteira a ser conquistada" permanece praticamente inalterada no imaginário militar. No entanto, estes textos foram escritos em contextos políticos bem diferentes. O livro de Martins foi escrito para divulgar o trabalho realizado pelos engenheiros do $5^{\circ}$ Batalhão de Engenharia de Construção e rebater as críticas recebidas pela ditadura em função dos desastres ambientais causados pela construção da rodovia BR- $364^{42}$, ligando Cuiabá a Porto

42 Algumas décadas mais tarde, a BR-364 voltará aos noticiários por ocasião da mobilização dos seringalistas brasileiros, liderados por Chico Mendes, associados com ambientalistas estrangeiros que pressionaram o Banco Mundial a cancelar o financiamento para a conclusão da pavimentação do trecho dessa rodovia que ligaria o Rio Branco, no Acre, à fronteira com o Peru. 
Velho. Já o livro do general Potyguara foi escrito quase duas décadas após o fim da ditadura para divulgar o papel social dos Pelotões Especiais de Fronteira no início do século XXI.

Se a representação da região amazônica no discurso militar sofreu poucas alterações, o contexto político nos âmbitos internacional, regional e nacional, mudou profundamente nas últimas décadas. Como já foi dito por João Roberto Martins Filho, o principal desafio dos analistas que estudam o pensamento militar sobre a Amazônia é identificar o que há de novo nas velhas percepções (Martins Filho, 2003). Na próxima secção veremos como o Exército analisa as mudanças estruturais na ordem política internacional, e a relação estabelecida por eles entre essas mudanças e as possíveis ameaças à soberania brasileira sobre a região amazônica.

2. As mudanças estruturais nos contextos internacional, regional e nacional e a resignificação da Amazônia pelo Exército ${ }^{43}$

\subsection{A nova ordem internacional}

O fim da Guerra Fria e a ampliação da agenda de segurança internacional são vistas com inquietação pelos militares brasileiros, pois diminuíram o grau de previsibilidade das situações nas quais a força pode ser empregada. A análise do panorama estratégico-militar internacional feita por oficiais do Exército reflete este sentimento ${ }^{44}$ :

O Estado permanece com o domínio territorial e perde, em termos de soberania, o papel de ser o único, exclusivo e impenetrável guardião de um conjunto de patrimônios humanos, naturais, culturais, lingüísticos, etc. que estão dentro de suas fronteiras. (...) $\mathrm{Na}$ atualidade, o Estado está envolto

\footnotetext{
${ }^{43}$ Uma versão preliminar desta seção pode ser consultada em: Marques (2004a).

${ }^{44}$ Apesar de não serem documentos oficiais do Exército, as monografias de final de curso produzidas pelos alunos das Escolas de Comando e Estado-Maior podem ser lidas como um conjunto de discursos legitimados pela instituição, como já apontamos na introdução.
} 
em normas de convivência internacional, bastante divergentes dos antigos princípios da igualdade entre Estados, da não-intervenção e da autodeterminação dos povos, do direito do mar e do direito internacional privado, onde a divisão clássica de direito público e privado perde sentido, já que as esferas de convivência tornam-se complexas e permeabilizam-se, criando novas interfaces jurídicas. Novos conceitos como 'dever de ingerência' e 'patrimônio da humanidade' revolucionaram as relações internacionais (Frederico, 2001:26).

As mudanças estruturais operadas na ordem internacional ocorreram num período em que as Forças Armadas brasileiras estavam readequando seu perfil organizacional. Depois de passar duas décadas atuando prioritariamente na defesa da ordem política instituída pelo golpe de 1964, os fardados estão cada vez mais voltados para uma missão militar clássica: garantir a soberania brasileira com a força das armas. Nas palavras de Eliézer Rizzo de Oliveira, "a soberania sobre o território, um tema que permaneceu subordinado à estratégia de contenção do comunismo ao longo de toda a Guerra Fria, volta agora com uma força revigorada (Oliveira, 1994:253)". Na citação abaixo, o oficial expressa esta mudança na orientação estratégica do Exército:

O Estado-Nação já não é o centro de todas as coisas, sua autonomia e suas funções tradicionais estão sendo erodidas por uma infinidade de tendências globalizadoras. As economias nacionais não têm estado nunca tão estreitamente ligadas como agora. A soberania, diz-se, está nos povos e é necessário defendê-la entre todos, com prudência, contra as formas mais extremas de arbitrariedade (Doval, 1997:23).

A globalização, como deixa transparecer a citação acima, é vista de maneira pessimista e se revela, em última instância, uma nova forma de colonialismo onde a expansão dos Estados não se faz mais através da conquista territorial. Em sua nova versão, o colonialismo se caracteriza pela conquista de mercados abastecedores e, principalmente, consumidores:

Os três principais atores que sobreviveram na Nova Ordem - EUA, Europa Ocidental e Ásia do Pacífico - estão lançados em uma franca luta de poder. O campo de batalha pode ser os países do Sul, a serem conquistados como mercado e como fornecedores de matérias-primas. Com isso, aquelas potências buscam formar o que Haushofer denominou, em 1937, de pan-regiões. A "Euroáfrica" seria implementada pela União Européia que 
busca seu complemento principalmente ao Sul do Mediterrâneo. A "PanÁsia”, embora sem definição de qual seria a potência reitora - Japão ou China - é uma possível realidade futura, haja vista ações realizadas neste sentido. Quanto à "Pan-América", os EUA buscam conformá-la com a promessa de expansão do NAFTA até a Patagônia (Facioli, 1998:06).

Outra faceta desta nova forma de colonialismo seria a dependência tecnológica dos países situados no hemisfério Sul em relação aos países ricos do hemisfério Norte:

O rápido avanço tecnológico tem privilegiado os países ricos. Eles utilizamse desse conhecimento para imporem-se aos mais pobres, negando-lhes ou dificultando-Ihes o acesso e criando um colonialismo tecnológico (Silva, 1997:5).

Deste novo quadro internacional, o Exército presume que as relações conflitivas Leste-Oeste reinantes durante a Guerra Fria, tendem a manifestar-se, agora, entre o Norte (forte) e o Sul (fraco):

O fenômeno da propalada globalização contribui para que diversos acontecimentos políticos, culturais, militares e outros sejam observados por todo o mundo, no exato momento em que ocorrem, gerando uma integração cultural, ideológica e sociológica que afeta positiva ou negativamente a identidade nacional dos Estados, particularmente, dos rotulados de "mais fracos". O desenvolvimento econômico desigual, prolongando a pobreza, em muitos países da América, fomenta subculturas violentas e desordem civil. As relações conflitivas pranteadas no passado, dentro do esquema Leste-Oeste, tendem a manifestar-se, agora, entre o Norte e o Sul (Silva e Luna, 1998:26).

No marco dessas novas tensões, a capacidade de interferência das organizações internacionais nos assuntos internos dos países do Sul seria maior, flexibilizando o conceito tradicional de soberania e criando o chamado "direito de ingerência":

O mundo encontra-se dividido em países desenvolvidos, emergentes e subdesenvolvidos, prevalecendo o interesse dos países desenvolvidos no gerenciamento das questões internacionais. Os interesses são atendidos por meios de alianças fortes e algumas vezes promovidos dentro de organizações internacionais, como a ONU e OTAN. As potências hegemônicas aprovam as intervenções em regiões onde seus interesses e oportunidades estiverem ameaçados, justificando a intervenção armada por 
razões humanitárias ou ecológicas, com 0 aval de organismos internacionais, como na Guerra do Golfo e nos conflitos étnicos na antiga lugoslávia (Bensusan, 2001:12).

No trecho acima citado é possível identificar um traço marcante da visão do Exército sobre a nova ordem internacional que está se configurando: a idéia de que as preocupações humanitárias e ecológicas dos países ricos do Norte $^{45}$ não são sinceras e, na verdade, "camuflam" interesses e oportunidades econômicas, ou seja, camuflam a cobiça desses países. Neste sentido, o fim da Guerra Fria teria apenas liberado os Estados nacionais dos constrangimentos ideológicos que orientavam suas ações militares.

Uma das iniciativas dos países ricos do Norte para tentar enfraquecer a soberania dos países do Sul, e mais especificamente dos países latino-americanos, seria transformar as Forças Armadas da América Latina em Guardas Nacionais:

Nesse aspecto atuariam as pressões para converter as Forças Armadas dos países latino-americanos em "Guardas Nacionais" ou reduzi-las para que seus encargos sejam problemas como o narcotráfico e outras funções menores. (...) A forma como se pretende construir a nova ordem internacional pode ser, para regiões periféricas, verdadeira ameaça que tente modificar os tradicionais conceitos de soberania e não intervenção (Doval, 1997:15-16).

$\mathrm{Na}$ dita "divisão de trabalho" proposta pelos países ricos do Norte para os países do Sul, os últimos desempenhariam atividades semipoliciais, deixando a segurança militar sob os cuidados de organizações internacionais. Na América a segurança militar do continente ficaria a cargo dos Estados Unidos, enquanto os países latino-americanos seriam pressionados a diminuir seus efetivos militares e mudar a missão de suas Forças Armadas, que deveriam preparar-se prioritariamente para 0 combate ao crime organizado, ao contrabando e ao tráfico de drogas:

Os Departamentos de Estado e de Defesa dos EUA já divulgaram estudos no sentido de estimular a adaptação das Forças Armadas latino-

\footnotetext{
${ }^{45}$ Os países ricos do Norte aos quais os oficiais do Exército se referem são: Estados Unidos, os países da União Européia e o Japão.
} 
americanas, incluindo o Brasil, para o trabalho semipolicial de combate às drogas. As Forças Armadas perderiam suas tradicionais funções de se preparar para uma guerra contra o inimigo externo. A paz do continente ficaria a cargo da única nação hegemônica no mundo atual que tem estatura política e militar para cumprir tal intento (Ribas, 2001:17).

O Exército brasileiro rejeita a tese de que deva participar diretamente do combate ao tráfico de drogas por dois motivos. Primeiramente, por não acreditar que o aparelho militar seja o instrumento mais eficaz para combater o tráfico. Em segundo lugar, por temer o poder de corrupção das organizações criminosas que controlam a fabricação e venda de drogas:

Os países em que as Forças Armadas tiveram uma participação direta no combate às drogas tiveram resultados desastrosos. Além de não solucionarem o problema do tráfico, sofreram um profundo desgaste na imagem das suas Forças singulares. Um número expressivo de militares foram corrompidos, outros passaram a trabalhar diretamente para as organizações criminosas ilícitas e a situação continuou inalterada (Ribas, 2001:32).

Além dos aspectos econômicos e tecnológicos, as tensões norte-sul, tal como são concebidas pelo Exército, envolvem também divergências na área ambiental:

Com o fim da bipolaridade e da guerra fria, as atenções das grandes potências se voltam para a concorrência econômica, para a disputa por novas áreas de influência e de projeção do poder, para a ecologia e a proteção ambiental (Bezerra, 1998:50).

O componente ambiental das tensões entre os países do Norte e do Sul é bastante enfatizado pelo Exército brasileiro, que relaciona a suposta flexibilização do conceito de soberania à possibilidade de uma intervenção militar na Amazônia:

O processo globalizante aborda diversos temas que têm gerado tensões no relacionamento entre países desenvolvidos e em desenvolvimento. Princípios considerados como objetivos nacionais permanentes de um país, tais como soberania e autodeterminação, têm sido tratados com muita indiferença (...) Dentro desse quadro de globalização, as grandes potências, particularmente os EUA, têm defendido a tese relativa a assuntos chamados de "interesses coletivos da Humanidade", que estão diretamente relacionados com a Amazônia (...) Intervenções armadas 
lideradas pelos norte-americanos, com ou sem a aquiescência do Conselho de Segurança da ONU, já podem ser observadas, como a realizada em Kosovo há pouco mais de dois anos, por motivos vinculados aos interesses da Humanidade (Branco, 2001:25).

Percebe-se no trecho acima que o Exército estabelece uma relação direta entre a intervenção militar que ocorreu na ex-lugoslávia e uma possível intervenção internacional na Amazônia. Por isso, é recorrente nas monografias de final de cursos dos alunos da ECEME o uso de termos como balcanização, e, até mesmo, mexicanização da Amazônia.

A balcanização da Amazônia estaria relacionada à existência de reservas indígenas na região que o Exército não vê com bons olhos porque acredita que essas reservas podem se transformar em "enclaves étnicos" que serviriam de justificativa para uma possível intervenção internacional na região:

A balcanização já começa a se delinear na Amazônia, implantando-se lá os 'apartheísmos' das reservas indígenas, que serão Estados dentro da Federação, facilmente manejados pelos países ricos e industrializados (Bellinati, 1998:25).

Já a mexicanização da Amazônia seria o resultado de dois fatores distintos: o vazio demográfico na região e a existência das reservas indígenas.

A exemplo da Amazônia brasileira, aquele território mexicano possuía um povoamento extremamente rarefeito. Localizado na região norte do México, todo aquele vasto espaço de enormes tesouros naturais foi perdido para os EUA, cujos habitantes o ocuparam primeiro pacificamente, comprando e demarcando terras de propriedade privada e nelas se instalando, depois, numa segunda fase, proclamando ali uma república títere - a República do Texas - e, finalmente, pelas armas, com a invasão militar e os exércitos de conquista e anexação, executores de um cálculo de expansão política, militar e econômica verdadeiramente inexorável (Branco, 2001:18).

$\mathrm{Na}$ citação acima o oficial do Exército alude às demarcações de terras indígenas na Amazônia atribuindo-Ihes o mesmo efeito pernicioso causado pela compra de terras por norte-americanos no norte do México. Desta percepção podemos depreender que as reservas indígenas representam uma ameaça à integridade territorial do Brasil não somente 
porque podem se converter em "enclaves étnicos" mas, principalmente, porque o processo de criação das reservas seria orquestrado por estrangeiros que as utilizariam, numa segunda etapa, como pretexto para intervir militarmente na Amazônia. Dito de outro modo, os militares do Exército não reconhecem a demarcação das reservas como resultado da luta dos povos indígenas pela recuperação de suas terras. $\mathrm{Na}$ visão castrense os indígenas seriam instrumentos de estrangeiros mal intencionados e não sujeitos de suas reivindicações. As raízes da desconfiança do Exército em relação indígenas já foram abordadas na primeira seção. Aqui cabe acrescentar que o Exército vem atuando nas terras indígenas no sentido de neutralizar a influência, tida como maléfica, dos atores transnacionais públicos não-estatais:

Os Yanomamis de Ariabu e Maturacá, com todas as suas tradições, convivem harmoniosamente com os militares do $5^{\circ} \mathrm{PEF}$, ainda que as instalações elétricas, a antena parabólica e outros avanços tecnológicos pareçam estranhos ao lado de arcos e flechas. (...) Tuxaua Joaquim parece satisfeito com o progresso. Empunhando um bastão de comando, torneado em pau-brasil, idêntico ao dos generais e vestindo sua melhor calça comprida, camisa e chinelos, recebe na pista do aeroporto todas as comitivas que por lá passam. Apresenta boas-vindas, através de seu intérprete, e volta para o convívio ao lado de suas cinco esposas (...) Os Cubeus e Guananos de Querari também convivem em perfeita harmonia com os militares do $2^{0}$ PEF e brindam os visitantes com emocionantes cânticos patrióticos, enaltecendo aquele diminuto pedaço de Brasil, evidenciando que também são brasileiros (Januário, 1996:50).

O trecho acima traz algumas informações importantes acerca do relacionamento entre os militares e os indígenas nos Pelotões Especiais de Fronteira. À primeira vista, o que mais impressiona no parágrafo citado é o tom adotado pelo oficial para se referir aos costumes indígenas. Oscilando entre o estranhamento e a desconfiança, a fala do oficial é um exemplo lapidar daquilo que os antropólogos denominam etnocentrismo. Entretanto, um fato narrado acima denota uma importante mudança na postura do Exército em relação aos indígenas: o tuxaua Joaquim porta um bastão idêntico ao Comandante Militar da Amazônia, um general do Exército. Este fato merece atenção, pois, se por um lado, ainda persiste no imaginário 
militar a percepção de que os índios são, em última instância, "inocentes úteis" manipulados para defender causas alheias, há o reconhecimento de que estes "inocentes" devem ao menos ser tratados com deferência, se o Exército quiser tê-los ao seu lado.

Recorrendo novamente à experiência dos antecessores portugueses, os militares brasileiros resignificam alguns procedimentos utilizados pelos colonizadores lusitanos para estabelecer alianças com os povos indígenas. A entrega do bastão de comando ao líder indígena local insere-se num conjunto de tradições inventadas pelo Exército brasileiro para simbolizar a importância da Amazônia para a instituição ${ }^{46}$. Estas tradições serão analisadas no final do próximo capítulo. Por ora, voltemos a tratar da mudança de postura do Exército.

Em 2003, o Estado-Maior do Exército promulgou uma portaria aprovando a diretriz para o relacionamento do Exército brasileiro com as comunidades indígenas $^{47}$. Nos primeiros parágrafos da portaria, o Exército

\footnotetext{
${ }^{46}$ Celso Castro (2002) reformula o conceito de invenção de tradições elaborado por Eric Hobsbawm para analisar as comemorações militares brasileiras. Nesta tese adotaremos a definição de Castro: "Minha perspectiva é parcialmente inspirada pela noção de 'invenção de tradições', consagrada por Eric Hobsbawm. Segundo esse autor, trata-se de fenômeno encontrado nos mais diversos países e contextos históricos, podendo também ser patrocinado por diferentes agentes, desde o Estado nacional até grupos sociais específicos. Comum a todos os casos seria a tentativa de expressar identidade, coesão e estabilidade social em meio a situações de rápida transformação histórica, através do recurso à invenção de cerimônias e símbolos que evocam continuidade com um passado muitas vezes ideal ou mítico. Afasto-me entretanto da concepção original de Hobsbawm num sentido importante: não oponho tradições 'inventadas' a outras vistas como 'tradicionais ou 'genuínas'. O uso que faço da idéia de 'invenção' busca, ao contrário, enfatizar o caráter de permanente invenção da cultura humana. Mais correto seria falarmos de uma tradição de invenção, pois esses elementos simbólicos são permanentemente reinventados e atualizados em diferentes contextos históricos. Ao mesmo tempo, existe o esforço cultural oposto de 'cristalizá-los', tornando-os reconhecíveis para os indivíduos. Essa dialética de invenção e convenção é um processo sempre inacabado (Castro, 2002:10-11)".

${ }^{47}$ É importante registrar que as determinações presentes na Portaria n. 020 contemplam particularmente duas antigas reivindicações das lideranças indígenas: 1- o respeito a diversidade cultural; 2- o reconhecimento de que a população local, especialmente a
} 
afirma que manteve historicamente um "relacionamento excelente" com as comunidades indígenas, sendo o Marechal Cândido Rondon o paradigma dessa convivência harmoniosa. A seguir, o documento evoca a Campanha de Guararapes como exemplo deste "relacionamento excelente", uma outra tradição inventada pelo Exército da qual trataremos no final do próximo capítulo. Mas é na orientação geral do documento que se percebe uma inflexão importante na antiga política de "integração dos índios" preconizada pelo Exército:

É fundamental que todos os escalões da Força Terrestre compreendam que os índios são nativos da terra e que Ihes são reconhecidos os costumes, sua organização social, a língua, as crenças e as tradições, além dos direitos originários sobre as terras que, tradicionalmente, ocupam (Brasil, 2003a:02).

O documento também determina que todos os militares, especialmente aqueles que terão contato direto com as comunidades indígenas, "conheçam e respeitem os hábitos, os costumes e as tradições, de forma a tornar harmônica e proveitosa para a Força Terrestre a convivência com os indígenas em todo o território nacional (Brasil, 2003a:02)". Os motivos pelos quais o Exército deve cultivar uma convivência harmoniosa com os índios na Amazônia são explicitados no terceiro item da orientação geral:

Por conhecer melhor a região onde vive e estar a ela perfeitamente adaptado, o índio pode constituir-se em um valioso aliado na obtenção de dados sobre a região, nas operações e nas ações rotineiras da tropa.

$\mathrm{Na}$ declaração acima vemos que a mudança na postura do Exército em relação aos povos indígenas está relacionada à idéia de que a Amazônia só poder ser defendida com o apoio destes. Aliás, as duas estratégias militares do Exército para a região (a presença e a resistência) dependem, em certa medida, dos indígenas para sua consecução.

indígena, é defensora histórica do território nacional, e portanto a melhor guardiã das fronteiras. Para mais informações acerca dessas reivindicações, ver: Heck (2000) e Heck, Loebens e Carvalho (2005). 
Na percepção dos fardados seus principais "concorrentes" na busca do apoio indígena na Amazônia são os atores transnacionais públicos nãoestatais, especialmente, as ONGs que lutam contra a devastação ambiental. O Exército tem uma grande dificuldade para compreender a forma de atuação das ONGs e dissociá-la da política oficial dos países aos quais essas organizações pertencem. Em determinados momentos, as ONGs são temidas por exercerem uma forte influência sobre seus países de origem: "As ONGs podem ser definidas como grupos com forte poder de influência sobre os respectivos governos e sobre as opiniões públicas nacionais (Almeida, 1998:16)". Em outros, elas são vistas como meros instrumentos dos países ricos, como na citação abaixo:

Atualmente, com inteira razão na sua concepção filosófica, mas, muitas vezes, desnecessariamente fanáticos ou extremistas na sua execução, os movimentos de preservação ambiental constituem questão de primeira ordem, exigindo que iniciativas capazes de provocar impactos no meio ambiente, mesmo que inexpressivos, sejam submetidas à consideração de órgãos governamentais competentes antes de sua implementação. Em prol dessa empreitada de âmbito mundial atuam, por outro lado, inúmeras organizações não-governamentais (ONG), que, na maioria dos casos, desconhecem limites territoriais, soberanias e direitos de propriedade, bem como se valem dessa "bandeira" para condicionar ou subjugar outros interesses nacionais não relacionados ao meio ambiente. A progressiva influência dessas entidades permite inferir que governos do "G-7" têm-se valido de sua atuação, financiando-as e direcionando-as como óbices ao desenvolvimento dos países periféricos, de forma que permaneçam como meros fornecedores de matérias-primas para os grandes (Lima, 1999:12).

Como reflexo dessa incompreensão, decisões como o cancelamento do financiamento do Banco Interamericano de Desenvolvimento (BID) para a pavimentação da rodovia BR-364 e iniciativas como as propostas de "troca de dívidas por natureza" que contaram com a participação ativa das Organizações Não Governamentais (ONGs) são interpretadas como ações deliberadas de chefes de Estados ${ }^{48}$ :

48 Para mais informações sobre o papel das ONGs em negociações ambientais internacionais ver: Leis (1991) e Villa (2004). 
Com base em tal concepção, o próprio Bush pressionou diretamente 0 governo do Japão para impedir a concessão ao Brasil de um financiamento para a conclusão da pavimentação da rodovia BR-364, no trecho que ligaria o Acre ao Peru, permitindo o acesso rodoviário aos portos deste país, no Oceano Pacífico. Thatcher apoiou uma série de esforços para vincular o pagamento da dívida externa de países como o Brasil à venda de recursos naturais destes. Por sua vez, Mitterrand declarou abertamente que o Brasil deveria ceder "parcelas de soberania" sobre a Amazônia, de modo a permitir a preservação das mesmas como um "Patrimônio da Humanidade". Outros dignitários estrangeiros, como o então vice-primeiro-ministro da Holanda, Ruud Lubbers, visitaram o Brasil propondo a adoção dos exóticos esquemas de "trocas de dívidas por natureza" (debt-for-nature swaps), com o abatimento de parcelas da dívida externa brasileira em troca da "preservação" de áreas florestais no País, principalmente na Amazônia (Magluf, 2000:19).

Os trechos acima mostram que na visão do Exército, as ONGs, mesmo quando agem como atores políticos autônomos que pressionam seus países de origem a adotar sanções contra o governo brasileiro para que ele preserve a floresta amazônica, contribuem indiretamente para alimentar a cobiça dos países industrializados sobre a região. Em última instância, as ONGs, assim como os índios, são "inocentes úteis" que estão preservando os recursos naturais da floresta para que eles sejam consumidos no futuro pelos países industrializados.

\subsection{Conflito e cooperação na América do Sul}

As análises conjunturais do Exército sobre a América do Sul, também apontam a existência de eventos que podem vir a comprometer a soberania brasileira sobre a Amazônia como a associação entre os traficantes de drogas e os movimentos guerrilheiros existentes na região andina. A respeito deste tema, percebe-se que o Exército brasileiro vê na região a substituição de uma antiga "ameaça", o comunismo, por sua "nova versão", a narcoguerrilha:

A antiga ameaça do $\mathrm{MCl}$ [Movimento Comunista Internacional] foi substituída por um ambiente ambíguo e variado, pleno de potenciais de paz 
e prosperidade, mas que também contém ocorrências significativas de violência transnacional. Dentro dessa ótica, os conflitos não modificam sua dinâmica e agora têm como vetor principal, especificamente na América Latina, a narcossubversão. A evolução do pensamento da CEA [Conferência dos Exércitos Americanos] reflete a preocupação com essas mudanças (Silva e Luna, 1998:26).

O termo narcoguerrilha foi cunhado pelo governo norte-americano e refere-se à idéia de que a ligação entre os movimentos guerrilheiros e os cartéis de drogas na América Latina é tão estreita que é impossível dissociá-los. Em termos gerais, o Exército brasileiro compartilha a tese norte-americana das narcoguerilhas. Porém, há uma diferença fundamental entre a época da Guerra Fria, quando o combate ao comunismo era uma diretriz comum a quase todos os Exércitos americanos ${ }^{49}$, e o atual panorama estratégico-militar na América do Sul.

Desde o governo de Ernesto Geisel, sobretudo após o rompimento do Acordo de Assistência Militar com os Estados Unidos em 1977, as Forças Armadas brasileiras vêm buscando alcançar a autonomia estratégica do país. O Exército, em particular, dedica-se desde esta época à elaboração de uma doutrina militar genuinamente brasileira ${ }^{50}$ que tem como um dos traços principais justamente a percepção de que os possíveis inimigos do Exército brasileiro estariam no hemisfério norte.

Por isso, as pressões do governo norte-americano para que as Forças Armadas da América Latina participem mais ativamente do combate ao tráfico de drogas e, mais recentemente, a forte presença dos Estados Unidos na Colômbia são vistas com cautela pelo Exército. ${ }^{51}$ Uma das maiores preocupações do Exército em relação ao Plano Colômbia é a possível transferência dos laboratórios de refino de cocaína da Colômbia para o Brasil. O Exército também teme que as Forças Armadas Revolucionárias da Colômbia (FARCs) e outros grupos guerrilheiros

\footnotetext{
${ }^{49} \mathrm{O}$ Exército cubano era uma exceção a esta regra.

${ }^{50}$ Sobre a evolução da doutrina militar do Exército ver: (Boaventura, 2001).

51 Mais informações a respeito da percepção do Exército brasileiro acerca do Plano Colômbia ver: Frederico (2001) e Ribas (2001). Para uma análise acadêmica destas percepções ver: Martins (2006).
} 
presentes na região andina venham a utilizar o território brasileiro como base de operações:

Conseqüentemente, não se descarta uma possível mudança do processo de refino, como um todo ou parte dele, da Colômbia para o Brasil, pela pressão das forças policiais e militares daquele país, apoiadas pela ajuda financeira norte-americana. Poder-se-á, também, aventar uma maior presença, em território brasileiro, de elementos das FARC e de outros grupos guerrilheiros colombianos, para realizarem 0 escambo da cocaína por armas contrabandeadas do Paraguai e do Suriname, ante a facilidade de permear a fronteira em face da pouca vivificação da região e da inexistência de efetivo controle fronteiriço de espaço aéreo (Madureira, 2000:26).

Para o Exército, se os cartéis colombianos, os contrabandistas e os movimentos guerrilheiros passarem a utilizar a Amazônia brasileira como base de operações, abrir-se-á mais um flanco para que a comunidade internacional acuse o governo brasileiro de ser incapaz de controlar seu próprio território e proteger a floresta amazônica.

Em razão das possibilidades acima citadas, é crescente no oficialato a percepção de que os problemas existentes nas faixas fronteiriças amazônicas não podem ser solucionados unilateralmente pelo governo brasileiro:

As novas ameaças à segurança, em um processo de integração, transcendem as fronteiras dos estados e, em certas ocasiões, ultrapassam sua capacidade de reagir individualmente (Doval, 1997:21).

Algumas ações do governo brasileiro, especialmente a proposta de criação de um SIVAM (Sistema de Vigilância da Amazônia) "regional”, é um indício de que a tese da cooperação nas áreas de segurança e defesa vem ganhando força no país:

O governo Brasileiro está fazendo gestões para que os países sulamericanos que fazem fronteiras com o Norte do País instalem sistema semelhante ao SIVAM, pois a luta contra o tráfico de drogas só será vencida com a participação de todos os países (Ribas, 2001:34).

A convicção de que apenas através da cooperação com os países vizinhos será possível solucionar os problemas de segurança que estão 
afetando a América do Sul vem operando paulatinas mudanças na maneira como o Exército vê o processo de integração em curso no Cone Sul.

A antiga postura defensiva da instituição em relação à cooperação nas áreas de segurança e defesa, que levou o general Leônidas Pires Gonçalves, então Ministro do Exército, a afirmar durante as negociações para a formação do Mercosul que o Brasil construiria um armamento nuclear se julgasse que a Argentina o faria ${ }^{52}$, foi substituída por uma visão mais positiva do processo de integração regional:

Embora ainda não se possa falar de integração militar, pode-se falar da existência de um clima de franca cooperação. As Forças Armadas não são obstáculo à integração regional (Facioli, 1998:49).

Como pode ser observado na citação acima, o Exército ainda é reticente a respeito da criação de uma aliança militar no Mercosul nos moldes europeus, mas não descarta essa possibilidade num futuro distante:

Cabe destaque o sentido da adoção de uma cooperação e não de uma integração, pois não há experiência suficiente para a utilização de uma única doutrina, um mesmo uniforme e o estudo de uma mesma hipótese de emprego, tudo direcionado para o MERCOSUL. A cooperação preconiza a aproximação, o conhecimento mútuo das Forças Armadas, a troca de conhecimento e prosseguimento seguro para o fortalecimento do MERCOSUL no Campo Militar (Heimo, 1999:39).

Este ponto é bastante significativo dado o peso do Exército na definição da Política de Defesa brasileira. Assim sendo, a possibilidade aventada - no discurso da instituição - de que os países sul-americanos virem a "trabalhar em conjunto frente às ameaças emergentes (Exército Brasileiro, 2003a:10)" pode ser considerada um indício de que esteja surgindo uma comunidade de segurança pluralista no Sul da América Latina nos termos de Karl W. Deusch.

De acordo com este autor, a principal condição para o surgimento de uma comunidade de segurança pluralista é a improbabilidade de ocorrer uma guerra entre os países que dela participam (Deutsch, 1982:280). Outro passo importante para a constituição de uma comunidade de segurança

52 Oliveira; Soares (2000:101). 
pluralista é a definição de ameaças que afetem todos os países membros dessa comunidade.

Na percepção do Exército, o Mercosul motivou o fim das hipóteses de emprego da força de cada país do bloco contra seus vizinhos:

Alcançada a integração no bloco o Brasil, país que concentra a maior extensão territorial, as maiores riquezas, a maior população e a mais expressiva economia da América Latina, estará fortalecendo a sua segurança externa por meio da aproximação comercial, militar e diplomática, pela consolidação das suas fronteiras, pelo declínio de antigas possibilidades de conflito, pela manutenção do equilíbrio estratégico da região, pela política externa desenvolvida e pela exploração e vigilância de regiões de importância estratégica. O MERCOSUL motivou o fim das hipóteses de emprego da força entre cada país do bloco com os seus vizinhos, consideradas no planejamento estratégico-militar (Heimo, 1999:50).

Uma próxima etapa no processo de aprofundamento da cooperação militar no âmbito do Mercosul seria a identificação de ameaças que afetassem toda a região:

$\mathrm{Na}$ América do Sul falta somente a conscientização da existência de um perigo que ameace todos seus povos, como pode ser, por exemplo, uma condenação ao eterno subdesenvolvimento num processo monitorado pelos "ricos", ou a colocação em dúvida da soberania sobre parte de seus territórios (Facioli, 1998:53).

No trecho acima é perceptível a visão institucional de que os problemas enfrentados pelo Brasil na sua relação com os países industrializados seriam compartilhados pelos outros países sul-americanos. Nestes termos, o aprofundamento da cooperação militar na América do Sul poderia auxiliar na defesa da Amazônia, se a assimetria em relação aos países ricos e o "direito de ingerência" passarem a ser vistos como ameaças a todos os países da região e não apenas ao Brasil.

Entretanto, o Exército não vê com bons olhos qualquer manifestação de discordância com as diretrizes dos países industrializados para a América do Sul. As críticas inflamadas do presidente venezuelano Hugo Chávez à administração de George W. Bush, por exemplo, não são bem recebidas pelos militares brasileiros. Esta percepção não é externada pelos 
oficiais da ativa, ficando esta tarefa para interlocutores privilegiados, como jornalistas, e oficiais da reserva. O artigo da jornalista Eliane Cantanhêde (2007) O fator Guiana reproduz com propriedade a percepção dos militares brasileiros acerca de Chávez:

$\mathrm{Na}$ avaliação da inteligência militar brasileira, Chávez é tão direto no seu discurso belicoso contra Bush ("el diablo") porque precisa de um "inimigo externo" para mobilizar o patriotismo -ou o bolivarianismo- interno. Mas, se tentar passar da palavra à ação, não será contra Washington nem mesmo contra a vizinha Colômbia. E por que não contra a Guiana? (...) O pretexto: a Venezuela reivindica até hoje cerca de $60 \%$ do território do vizinho. $O$ motivo real: a Guiana recebe vultosas ajudas dos EUA (além do Canadá e do Reino Unido) e, em contrapartida, é generosa ao oferecer espaço e condições para treinos e operações militares americanas - bem ali, na fronteira com o Brasil e com a Venezuela. O Brasil não gosta e há anos observa. Chávez vai além - teme a possibilidade de uma base militar americana nas suas barbas. Estejam ou não delirando os estrategistas brasileiros, o fato é que Chávez tem dado demonstrações de que não está brincando. Qualquer que seja a brincadeira, o Brasil vai acabar metido nela, por ar, por terra, e não apenas pela diplomacia (Cantanhêde, 2007).

Na citação acima é perceptível a atualização de um antigo temor dos militares brasileiros: o envolvimento do Brasil num conflito armado entre países vizinhos que disputam o mesmo território no arco amazônico. Mas a prevenção dos militares brasileiros em relação ao presidente venezuelano não se limita à atualização de antigos temores. A política externa e militar de Hugo Chávez representa, para os fardados, um novo fator de instabilidade na América Latina. Esta percepção está expressa num artigo recente de um ex-Comandante Militar da Amazônia, o general da reserva Luiz Gonzaga Schröeder Lessa:

Temos visto, com preocupação, a desenvoltura com que o presidente da Venezuela, Coronel Hugo Chávez, se vem movimentando no continente latino-americano, projetando a sua imagem pessoal, desejoso de ser o herdeiro do ditador Fidel Castro na sua implacável pregação contra Bush e a política norte-americana (...) O argumento de Hugo Chávez de que se prepara para uma provável invasão norte americana não encontra consistência na realidade dos fatos (...) o que Chávez pretende investir é uma gota d'água num oceano e não possibilita construir Forças Armadas com efetivo poder dissuasório. Se para o irmão do Norte pouco representa, 
para os do Sul, os investimentos programados são desproporcionais, geram desconfianças (...) Os programas em curso na Venezuela (...) podem conduzir a América Latina a uma indesejável corrida armamentista e motivar disputas, hoje adormecidas, gerando instabilidades e ameaças na sensível fronteira amazônica, por si só, palco das ambições e da cobiça internacional (Lessa, 2007:24-25).

\subsection{Os problemas nacionais}

Todavia, não é apenas a presença de atores transnacionais públicos e não-públicos nos lindes da Amazônia brasileira e a emergência de lideranças políticas com um discurso calculadamente exagerado nos países andinos que trazem inquietação à caserna. Um conjunto de problemas localizados no território brasileiro, como os conflitos que opõe os latifundiários aos defensores das reservas extrativistas e trabalhadores sem terra, a degradação do meio ambiente, o garimpo ilegal em terras indígenas, o contrabando de madeira, minerais e armas, além da biopirataria, também pode, na visão castrense, tornar a região mais vulnerável à cobiça internacional. Estes problemas seriam agravados pelo vazio demográfico existente na Amazônia e a escassa presença governamental na área.

Aqui, novamente, a existência de um vazio demográfico na Amazônia aparece relacionada à suposta falta de comprometimento da população local com a garantia da soberania brasileira sobre a região. $O$ Exército acredita que, em face do descaso do poder público, os criminosos que atuam nas áreas fronteiriças podem vir a aliciar os habitantes dessas regiões:

Em face do exposto, provavelmente ocorrerá uma influência negativa na população brasileira na extensa faixa lindeira, ocasionando cumplicidade com os narcotraficantes, mais uma sensível onda de corrupção, em todos os níveis e setores, e de maior penetração em determinados segmentos do Poder Nacional (Madureira, 2000:26). 
A apresentação dos problemas apontados nos parágrafos anteriores como justificativa para uma maior presença do Exército na Amazônia, tem suscitado vários questionamentos, pois se os fardados temem as conseqüências da "ausência do Estado" na região, a presença do Exército na Amazônia também se mostrou bastante contraproducente durante a vigência da ditadura militar (Alves, 1984:165-166). Episódios como a atuação do major Curió no garimpo de Serra Pelada (Costa, 1994:111-134) - que dispunha da área como se ela fosse um "espólio de guerra" conquistado após sua participação no desbaratamento da guerrilha do Araguaia - certamente contribuem para reforçar essa visão. Neste sentido, haveria uma disjunção entre o discurso militar, que vê na ocupação desordenada da região uma ameaça à soberania nacional, e a presença militar, que concorreria para o agravamento desta ocupação desordenada (Furniel, 1993).

No próximo capítulo analisaremos a presença do Exército na Amazônia a partir da Nova República, a construção de suas estratégias militares e de seus mitos para a região. 


\section{CAPÍTULO III}

O EXÉRCITO NA AMAZÔNIA: CONSTRUINDO ESTRATÉGIAS E MITOS

\section{A presença castrense na Amazônia e a construção das estratégias militares para a região ${ }^{53}$}

\subsection{O perfil organizacional do Exército na Amazônia}

O Exército brasileiro conta com sete Comandos Militares: o Comando Militar da Amazônia sediado em Manaus; o Comando Militar do Oeste sediado em Campo Grande; o Comando Militar do Planalto sediado em Brasília; o Comando Militar do Nordeste sediado em Recife; o Comando Militar do Leste sediado no Rio de Janeiro; o Comando Militar do Sudeste sediado em São Paulo; e o Comando Militar do Sul sediado em Porto Alegre.

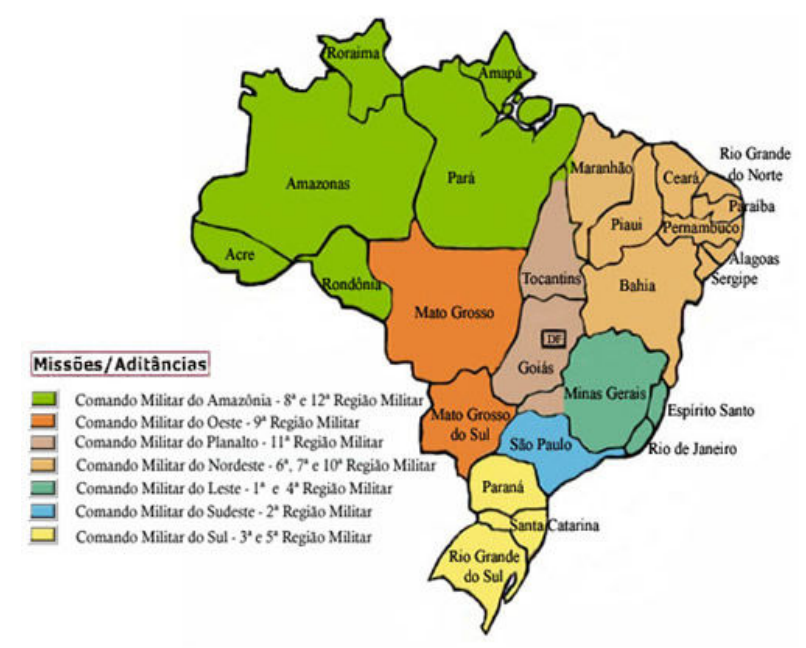

Figura 1- Mapa das Organizações Militares do Exército

Fonte: Exército Brasileiro (2006a)

\footnotetext{
${ }^{53}$ Utilizarei nesta seção apenas os dados fornecidos pelo Exército em seus documentos públicos.
} 
O Comando Militar da Amazônia (CMA) tem jurisdição sobre os territórios da $8^{\mathrm{a}}$ Região Militar/ $8^{\mathrm{a}}$ Divisão de Exército, com sede em Belém, e da $12^{a}$ Região Militar, com sede em Manaus, e sua área de responsabilidade abrange os Estados do Acre, Amapá, Amazonas, Pará, Rondônia, Roraima e partes do Tocantins e Maranhão. As Regiões Militares são Grandes Comandos administrativos que têm como atribuição prover o apoio logístico aos demais Grandes Comandos, às Brigadas e às diversas unidades enquadradas em sua área geográfica de responsabilidade. A $8^{\text {a }}$ Região Militar $/ 8^{a}$ Divisão de Exército ${ }^{54}$ tem jurisdição sobre os Estados do Pará e do Amapá, partes do Estado do Tocantins (limitadas ao sul pelos municípios de Wanderlândia, Babaçulândia e Xambioá), e partes do Estado do Maranhão (as áreas dos municípios de Açailândia, João Lisboa, Imperatriz, Amarante do Maranhão, Montes Altos, Sítio Novo, Porto Franco, Estreito e Carolina). A $12^{\mathrm{a}}$ Região Militar tem jurisdição sobre os Estados do Amazonas, do Acre, de Roraima e de Rondônia ${ }^{55}$.

O Comando Militar da Amazônia é composto por cinco grandes unidades operacionais, as Brigadas de Infantaria de Selva. A $1^{\text {a }}$ Brigada de Infantaria de Selva localizada em Boa Vista (RR); a $2^{\text {a }}$ Brigada de Infantaria de Selva localizada em São Gabriel da Cachoeira (AM); a $16^{a}$ Brigada de Infantaria de Selva localizada em Tefé (AM); a $17^{\text {a }}$ Brigada de Infantaria de Selva localizada em Porto Velho (RO); e a $23^{\text {a }}$ Brigada de Infantaria de Selva ${ }^{56}$ localizada em Marabá (PA) (Brasil, 2006). No âmbito dessas

${ }^{54}$ A $8^{\text {a }}$ Região Militar recebeu a denominação histórica Região Forte do Presépio, homenageando a primeira fortificação construída pelos portugueses na Amazônia. O Forte do Presépio foi construído em 1616 e está localizado em Belém.

55 A $12^{a}$ Região Militar recebeu a denominação histórica Mendonça Furtado em homenagem ao irmão do marquês de Pombal, Francisco Xavier de Mendonça Furtado, que criou em 1755 a Capitania de São José do Rio Negro, embrião do atual estado do Amazonas. Mendonça Furtado foi o responsável pela criação de vários núcleos populacionais e fortificações. Credita-se a ele também a introdução de lavouras, como a de cacau, algodão, tabaco e café e a iniciativa de criação de gado na região (Exército Brasileiro, 2005a).

${ }^{56}$ Devido ao Plano de Estruturação do Exército, a $23^{\mathrm{a}}$ Brigada de Infantaria de Selva passou a subordinar-se diretamente à $8^{\mathrm{a}}$ Região Militar/Divisão de Exército (Exército 
Brigadas existem quatro Forças de Ação Rápida ${ }^{57}$ : $01^{0}$ Batalhão de Infantaria de Selva, com sede em Manaus, A; o $52^{\circ}$ Batalhão de Infantaria de Selva, com sede em Marabá (PA); o $4^{\circ}$ Esquadrão de Aviação do Exército e a $3^{a}$ Companhia de Forças Especiais, ambos com sede em Manaus.

O Comando Militar da Amazônia conta igualmente com $02^{\circ}$ Grupamento de Engenharia de Construção, sediado em Manaus. Este grupamento é um Grande Comando responsável pela construção de aquartelamentos e suas infra-estruturas e, principalmente, pela construção e manutenção de estradas.

Além disso, o CMA pode operar conjuntamente com a Marinha através do $9^{\circ}$ Distrito Naval localizado em Manaus e do $4^{\circ}$ Distrito Naval localizado em Belém, e com a Força Aérea por meio do I Comando Aéreo Regional com sede em Belém e do VII Comando Regional com sede em Manaus.

Atualmente, o Exército tem um efetivo de aproximadamente 25.000 militares servindo em 62 localidades da Amazônia (Exército Brasileiro, 2007b). Considerando apenas o período histórico abarcado por esta tese, ou seja, o período pós-autoritário, nota-se que houve de fato um movimento de transferência de grandes unidades operacionais das regiões sul-sudeste para a região amazônica. Das cinco Brigadas pertencentes hoje ao Comando Militar da Amazônia, três foram transferidas de outras regiões do país a partir dos anos 90. A $1^{\text {a }}$ Brigada de Infantaria de Selva é oriunda da $1^{\text {a }}$ Brigada de Infantaria Motorizada de Petrópolis (RJ) e foi transferida para Boa Vista (RR) no início de $1992^{58}$ (Exército Brasileiro, 2007c). A $16^{\mathrm{a}}$

Brasileiro, 2007g). As Divisões de Exército são unidades operativas que abrigam um número variável de brigadas.

${ }^{57}$ As Forças de Ação Rápida são organizações militares mantidas em condições de emprego imediato, possibilitando ao Exército uma pronta resposta a situações em que a rapidez e a oportunidade constituam os fatores preponderantes para o emprego, dentro ou fora do território nacional (Brasil, 2006).

${ }^{58}$ A $1^{\text {a }}$ Brigada de Infantaria de Selva tem como patrono o engenheiro militar português Manoel da Gama Lobo D'Almada que no século XVIII foi governador da Capitania de São José do Rio Negro (Exército Brasileiro, 2007c). 
Brigada de Infantaria de Selva ${ }^{59}$ é oriunda da $16^{a}$ Brigada de Infantaria Motorizada de Santo Ângelo (RS) e foi transferida para Tefé em 1993 (Exército Brasileiro, 2007d). E a $2^{\mathrm{a}}$ Brigada de Infantaria de Selva ${ }^{60}$ é oriunda da $1^{\text {a }}$ Brigada Estratégica de Niterói (RJ) e começou a ser transferida para São Gabriel da Cachoeira (AM) em 2004 (Exército Brasileiro, 2007e). ${ }^{61}$ Esta transferência de unidades militares pode ser facilmente interpretada como um sinal de que o Exército está reconfigurando sua estrutura organizacional em resposta às mudanças estruturais no contexto internacional detalhadas na seção anterior.

Mas, se analisarmos mais detidamente o perfil das organizações militares que estão sediadas na região amazônica, perceberemos que a mudança na estrutura organizacional do Exército não foi acompanhada de uma mudança profunda no pensamento estratégico do Exército sobre esta região. Em linhas gerais, o Exército atualiza, ou melhor, atribui novos significados à presença militar e às estratégias que serão aplicadas na área.

\footnotetext{
${ }^{59}$ A $16{ }^{\text {a }}$ Brigada de Infantaria de Selva recebeu a denominação histórica de Brigada das Missões (Exército Brasileiro, 2007d).

${ }^{60}$ A $2{ }^{a}$ Brigada de Infantaria de Selva tem como patrono o índio Araribóia que lutou ao lado dos portugueses para expulsar os franceses do Rio de Janeiro no século XVI (Exército Brasileiro, 2007e).

${ }^{61}$ Já as duas Brigadas que pertencem originalmente à área jurisdicional do CMA são um pouco mais antigas. A $17^{\mathrm{a}}$ Brigada de Infantaria de Selva foi criada em 1980 substituindo o Comando de Fronteira Acre-Rondônia, datado de 1969, e o $3^{\circ}$ Grupamento de Fronteira, criado em 1976. A $17^{\mathrm{a}}$ Brigada de Infantaria de Selva recebeu a denominação histórica "Brigada Príncipe da Beira", em homenagem ao forte construído pelos portugueses no século XVIII em Rondônia. (Exército Brasileiro, 2007f). A $23^{a}$ Brigada de Infantaria de Selva foi criada em 1976, mas só ocupou suas atuais instalações no centro de Marabá em 1987. Durante 11 anos a $23^{\mathrm{a}}$ Brigada funcionou nas dependências do $52^{\circ}$ Batalhão de Infantaria de Selva no Km 08 da rodovia Transamazônica (Exército Brasileiro, 2007g).
} 


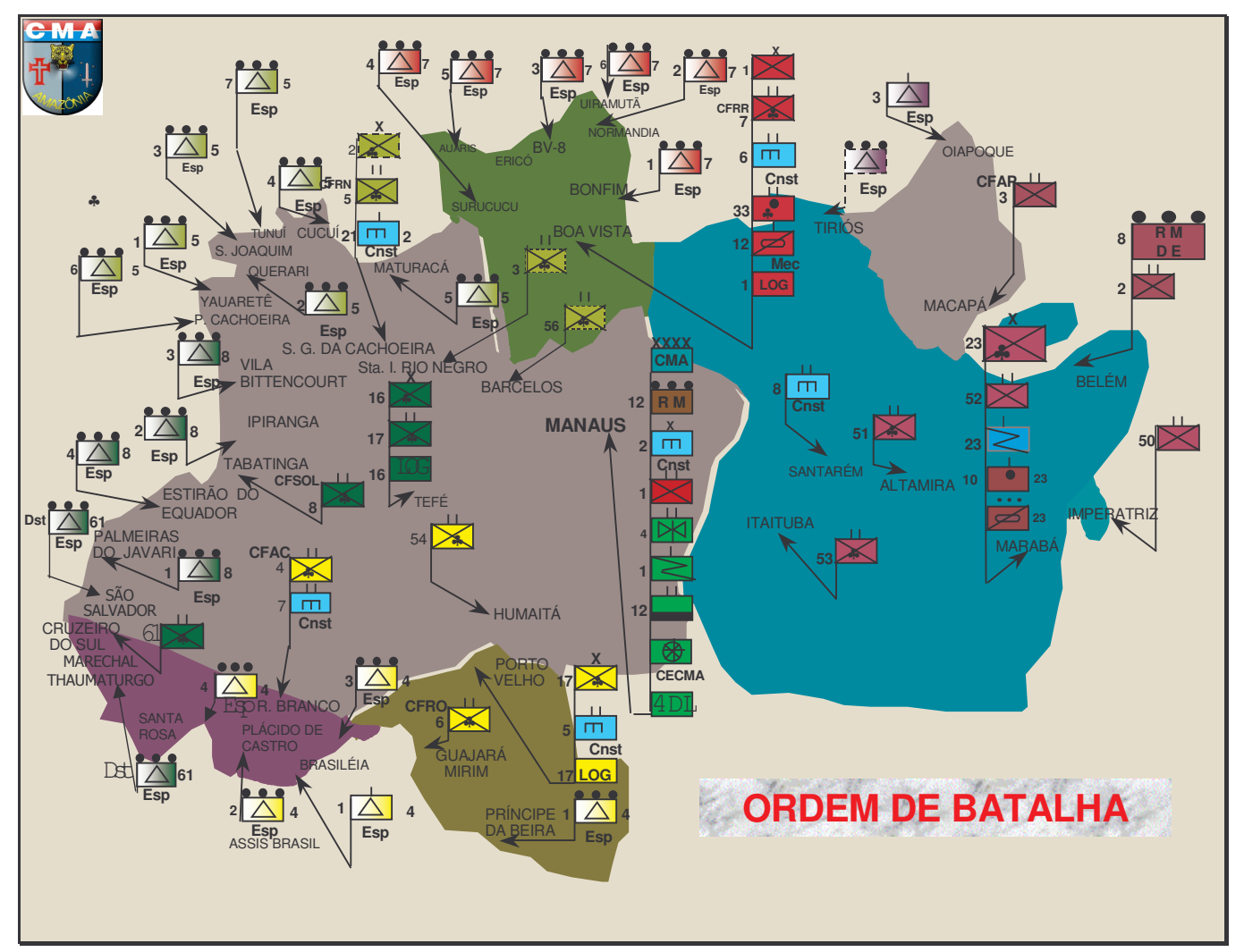

Figura 2 - Ordem de Batalha

Fonte: Villa Bôas (2005)

A disposição das organizações militares do Exército exposta na Ordem de Batalha mostra que a infantaria é a arma com o maior contingente na Amazônia. Mostra também que a maioria das unidades do Exército está localizada em área de fronteira. São os Batalhões de Infantaria de Selva (BIS) e os Pelotões Especiais de Fronteira (PEF).

A proposta de criar uma nova organização militar do Exército na região parte do Comando Militar da Amazônia, que encaminha suas demandas ao Estado-Maior do Exército, o qual repassa-as ao Alto Comando do Exército ${ }^{62}$. Após passar por esta instância, o Comandante do Exército decide a pertinência ou não de construir a organização, levando em conta a disponibilidade de verbas para 0 andamento das obras e a avaliação do Ministério da Defesa (Lopes, 2001). A maior fonte de recursos

\footnotetext{
${ }^{62}$ O Alto Comando do Exército é composto pelos generais-de-exército.
} 
para a Construção de Pelotões Especiais de Fronteira vem do Programa Calha Norte, que será detalhado no quinto capítulo.

Os Batalhões de Infantaria de Selva (representados na Ordem de Batalha com um " $x$ ") são as unidades táticas das Brigadas de Infantaria aptas para operar em região de selva, combinando o fogo, o movimento e o combate aproximado. Instruído para combater a pé, o BIS tem várias limitações, como a pouca mobilidade, a dependência acentuada dos meios de comunicação, e o reduzido poder de fogo (Brasil, 1997:1-3/1-5).

O BIS tem como missões: a) em operações ofensivas, destruir o inimigo localizado em sua área de atuação e/ou conquistar objetivos específicos do terreno, b) em operações defensivas, manter acidentes capitais, especialmente os que permitem bloquear e/ou controlar vias de circulação fluviais e terrestres, c) no contexto da Segurança Integrada, pacificar ou participar da pacificação de área, d) em área de fronteira, além das missões de combate, deve vigiar a faixa fronteiriça, e) no combate de resistência, que será exposto a seguir, operar em uma área de combate alternando suas companhias de fuzileiros de selva (Brasil, 1997: 1-3). O Batalhão de Infantaria de Selva é constituído por um comando, um estadomaior, uma companhia de comando e serviços e três companhias de fuzileiros de selva (Brasil, 1997:1-6). Com exceção do $1^{\circ}$ e do $52^{\circ} \mathrm{BIS}$, os Batalhões de Infantaria de Selva não estão preparados para o pronto emprego fora de seu raio de ação.

É importante ressaltar que o Exército se prepara para o combate na selva contra qualquer tipo de inimigo, seja ele convencional, como um Exército, ou irregular, como uma guerrilha. Isso porque o Exército, desde o início deste século, foca sua preparação em capacidades ${ }^{63}$ e não mais em ameaças (Brasil, 2006).

\footnotetext{
${ }^{63}$ As seguintes capacidades são desejadas para a Força Terrestre, em nível estratégico: a) atender com presteza e eficácia a todas as hipóteses de emprego, normalmente integrando forças combinadas, devendo, para isso, manter-se permanentemente preparada em nível de Eficiência Operacional; b) Configurar a força desejada, em função das características de cada missão a ser cumprida, pela reunião, no momento oportuno, dos meios necessários, tendo como base módulos de brigada de natureza diversas; c)
} 
Quando sediado em área de fronteira, o BIS possui as mesmas características dos outros batalhões, acrescidas da capacidade de, desde os tempos de paz, realizar a vigilância e a vivificação das fronteiras, constituir a presença armada brasileira em regiões fronteiriças, agir como fator de dissuasão para os elementos externos e como agente de operações psicológicas junto à população que gravita em torno dos Pelotões Especiais de Fronteira (Brasil, 1997:9-1).

Os Pelotões Especiais de Fronteira (representados na Ordem de Batalha com um triângulo) tem como missão vigiar a fronteira e cooperar com a vivificação da área. As funções dos Pelotões Especiais de Fronteira (PEF) não se limitam à atividade militar (combate), estendendo-se também às atividades complementares como a produção, em pequena escala, de gêneros alimentícios de origem vegetal e animal (vida) e à prestação de serviços para si próprio e para a comunidade civil existente ao redor do aquartelamento (trabalho) (Brasil, 1997:9-4). Nos PEF se evidencia o que o Exército define como a tríade da soberania: vida, combate e trabalho. $\mathrm{O}$ quadro abaixo mostra as atividades relativas a cada um dos elementos da tríade.

\begin{tabular}{|c|c|c|}
\hline VIDA & COMBATE & TRABALHO \\
\hline Saúde & Vigiância & Agropecuária \\
\hline Educação & Guarda & Tecnologia \\
\hline Lazer & $\begin{array}{c}\text { Reconhecimento de } \\
\text { fronteira }\end{array}$ & Serviços \\
\hline Alimentação & Adestramento & Construção \\
\hline
\end{tabular}

Figura 3 - Tríade da Soberania

projetar forças no âmbito interno e regional e, com limitação, no extra-continental, valendose da mobilidade estratégica; d) durar na ação, sustentada por um adequado apoio logístico, tanto em operações convencionais de curta ou média duração, como em operações não convencionais de longa duração, nestas últimas utilizando-se preponderantemente de recursos locais; capacidades logísticas de apoiar, também forças internacionais de valor limitado; e) crescer em curto prazo por mobilização (Brasil, 2006). 
Até poucas décadas atrás, o militar destacado para servir numa unidade de fronteira na Amazônia não era recrutado entre voluntários. Em geral, a transferência para um PEF era encarada como punição (Stevaux, 1996:39). Atualmente a situação é diversa. Os militares que servem nas unidades de fronteira são voluntários e recebem do Exército incentivos materiais e simbólicos para cumprirem suas missões na Amazônia. A antropóloga Roberta Mélega entrevistou alguns oficiais e esposas de militares que serviam na região conhecida como "Cabeça do Cachorro" em $2000^{64}$ e obteve algumas informações interessantes a esse respeito.

A verba de transferência para uma unidade de fronteira depende da distância, do tempo de serviço, do número de dependentes (os solteiros ganham menos) e da patente do militar em questão. Nestes termos, um militar que sai de uma unidade no sul do país para servir na Amazônia ganhará mais do que um militar que for transferido do Pará para o Amazonas, por exemplo. A esposa de um tenente do sul disse à antropóloga que seu marido receberia cerca de 70 mil reais de verba de transferência, incluindo a ida e a volta da Amazônia.

A cada dois anos um oficial pode indicar cinco opções de localidade onde deseja servir, tendo que permanecer ao menos dois anos na localidade escolhida para poder pedir uma nova transferência. Segundo relatos de oficiais, a Amazônia tem sido cada vez mais colocada como primeira opção de escolha. Dos oficiais formados pela Academia das Agulhas Negras em 2000, quatro escolheram servir em São Gabriel (AM). $O$ oficial mais bem colocado da lista de formandos era $023^{\circ}$ e o pior colocado era $\circ 68^{\circ}$, de um total de 160 militares. A esposa de um dos tenentes que serviam em São Gabriel relatou que o marido precisou da influência de um general para conseguir uma vaga na unidade (Mélega, 2007).

${ }^{64}$ Roberta Mélega passou três meses na Cabeça do Cachorro, região do estado do Amazonas. Neste período entrevistou pessoas no PEF de Maturacá, no PEF de São Joaquim, no $5^{\circ}$ Batalhão de Infantaria de Selva e na $21^{\text {a }}$ Companhia de Engenharia de Construção. As duas últimas unidades ficam em São Gabriel da Cachoeira (Mélega, 2007). 
A concessão da Medalha de Serviço Amazônico também exerce fascínio sobre os jovens oficiais. Instituída pelo Decreto 93.209 de 03 de setembro de 1986, essa medalha premia os militares do Exército que hajam prestado relevantes serviços em organizações militares da Amazônia. O passador e a barreta serão: a) de bronze com uma castanheira para os militares que tenham completado dois anos, ininterruptos ou não, se passados em guarnições especiais de $1^{\text {a }}$ categoria e três anos, ininterruptos ou não, nos demais locais de área amazônica; b) de prata com duas castanheiras para os que tenham completado cinco anos, ininterruptos ou não, passados em guarnições de área amazônica; e c) de ouro com três castanheiras, para os que tenham completado dez anos, ininterruptos ou não, passados em guarnições da área amazônica. Poderá ser concedida a medalha com barreta e passador de bronze aos comandantes, chefes e diretores que, sendo movimentados para fora da área amazônica, por necessidade de serviço e antes do término do prazo mínimo, tenham prestado relevantes serviços na área amazônica (Brasil, 2003:05). Abaixo segue uma reprodução da medalha:

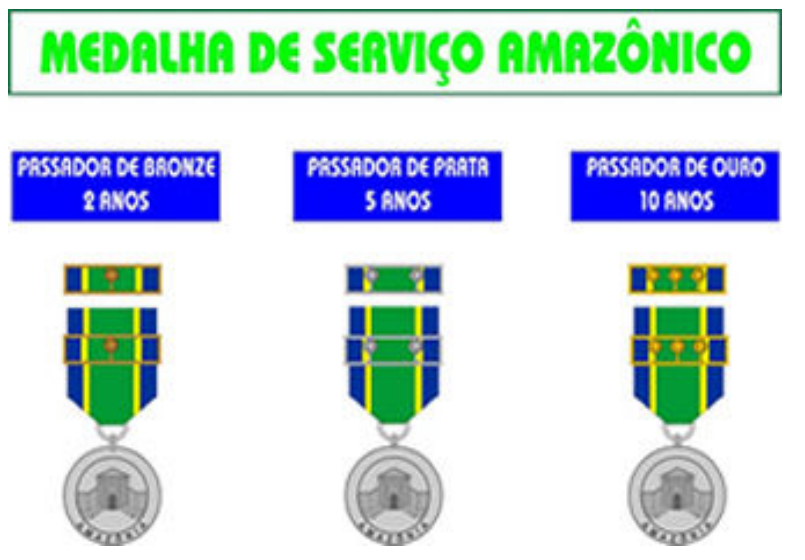

Figura 4 - Medalha de Serviço Amazônico

Fonte: Exército Brasileiro (2003b)

Os oficias entrevistados por Mélega afirmaram que ser agraciado com a Medalha de Serviço Amazônico ajuda numa futura promoção. Além disso, a estadia na Amazônia conta $1 / 3$ a mais de tempo para a aposentadoria (Mélega, 2007). 
$O 2^{\circ}$ Grupamento de Engenharia de Construção ( $2^{\circ} \mathrm{GEC}$ ), outro Grande Comando do Exército presente na Amazônia, também desempenha um papel de destaque na região. O $2^{\circ} \mathrm{GEC}$ é composto por cinco unidades. O $5^{\circ}$ Batalhão de Engenharia de Construção ${ }^{65}$ foi criado em 1966 e está instalado em Porto Velho (RO). De suas Companhias de Engenharias surgiram o $6^{\circ}$ e $\circ 7^{\circ}$ BEC (Exército Brasileiro, 2006b). $O 6^{\circ}$ Batalhão de Engenharia de Construção ${ }^{66}$ foi criado em 1969 e está instalado em Boa Vista, Roraima (Exército Brasileiro, 2006c). $O 7^{\circ}$ Batalhão de Engenharia de Construção foi criado em 1969 na cidade de Cruzeiro do Sul, no Acre, e foi transferido para Rio Branco, capital do mesmo estado, em 1992 (Exército Brasileiro, 2006d). O $8^{\circ}$ Batalhão de Engenharia de Construção ${ }^{67}$ foi transferido de Lages, Santa Catarina para Santarém (PA) em 1970 (Exército Brasileiro, 2006e). E a 21 ${ }^{\mathrm{a}}$ Companhia de Engenharia de Construção é oriunda do $1^{\circ}$ Batalhão Rodoviário de Caicó (RN) e foi transferido em 1973 para Uaupés, atual São Gabriel da Cachoeira (Exército Brasileiro, 2006f).

A engenharia do Exército é uma arma de apoio ao combate que tem como missão principal apoiar a mobilidade, a contramobilidade e a proteção (Brasil, 1999:1-3). As unidades de Engenharia de Construção atuam, geralmente, em áreas de retaguarda do exército de campanha, na zona de administração ou na zona de interior, onde executam trabalhos que exigem

\footnotetext{
${ }^{65} \mathrm{O} 5^{\circ}$ Batalhão de Engenharia de Construção tem como patrono o tenente coronel Carlos Aloysio Weber, primeiro comandante do Batalhão (Exército Brasileiro, 2006b).

${ }^{66} \mathrm{O} 6{ }^{\circ}$ Batalhão de Engenharia de Construção tem como patrono Simón Bolívar (Exército Brasileiro, 2006c).

${ }^{67} \mathrm{O} 8^{\circ}$ Batalhão de Engenharia de Construção já atuou em vários Estados da Federação. Ele foi criado em junho de 1908 para dotar a Comissão Rondon de um núcleo de tropa destinado à execução dos trabalhos de construção, transporte e vigilância. $\mathrm{O} 8^{\circ} \mathrm{BEC}$ foi instalado em Juruena (MT) e teve como primeiro comandante o Marechal Rondon, patrono do Batalhão. Em 1931, o $8{ }^{\circ} \mathrm{BEC}$ foi transferido para Quitaúna (SP), onde permaneceu até 1931 quando foi transferido para Pindamonhangaba (SP). Em 1932, o $8{ }^{\circ} \mathrm{BEC}$ deixou o Estado de São Paulo com a missão de reconstruir e preservar a antiga estrada de rodagem Lages-Passo do Socorro. Permaneceu em Lages (SC) até 1970 quando foi transferido para Santarém (Exército Brasileiro, 2006e).
} 
técnica mais aprimorada ou grande capacidade de construção (Brasil,1999: $1-6)$.

Em tempo de paz, os Batalhões de Engenharia de Construção realizam trabalhos de interesse da população civil, tais como: a) instalações (hospitais, escolas, planos habitacionais); b) serviços essenciais à população (luz, esgoto); c) assistência às atividades econômicas produtivas; d) construção de estradas e pontes (Brasil, 1999:9-12). Ou seja, os BEC, em tempo de paz, são unidades militares voltadas primordialmente para realização de atividades cívico-sociais.

O perfil das unidades do Exército na Amazônia revela que, na sua grande maioria, elas dedicam-se primordialmente a realizar ações cívicosociais e assegurar a presença estatal na região. Do ponto de vista doutrinário, a configuração das unidades militares na região remete à estratégia da presença.

\subsection{A estratégia da presença}

No quarto extrato do Sistema de Planejamento do Exército, mais conhecido como SIPLEX-4, a estratégia da presença é caracterizada como "a presença militar no território nacional e suas extensões, com a finalidade de cumprir a destinação constitucional e contribuir de modo eficaz para o desenvolvimento da Nação (Brasil, 2006:08)". A presença das Forças Armadas nas áreas estratégicas Amazônia e Guianense ${ }^{68}$, além de

${ }^{68}$ O SIPLEX-4 divide o país em seis áreas estratégicas: Amazônia, Guianense, CentroOeste, Bacia do Prata, Nordeste Brasileiro e Núcleo Central Brasileiro. As áreas estratégicas são porções do território nacional e, conforme o caso, partes do território estrangeiro que venham a ter envolvimento em possíveis operações militares. A área estratégica Amazônia inclui, no Brasil: Amazonas, Pará (exceto o norte do estado), região sul do Amapá, Acre, Maranhão (até o meridiano de São Luiz), Tocantins (ao norte do paralelo que passa pela localidade de Araguaína), Roraima (parte oeste) e Rondônia; no exterior: partes da Venezuela, da Colômbia, do Peru e da Bolívia. E a área estratégica Guianense, vinculada à área estratégica Amazônia e à região do Caribe; inclui a Guiana, o Suriname o Departamento de Ultramar da França (Guiana Francesa) e parte da 
proporcionar um conhecimento mais detalhado desses ambientes operacionais, na opinião do Exército, contribui com o desenvolvimento regional, atenuando parte dos problemas que podem ser usados como pretexto para uma intervenção internacional na região amazônica (Abreu, 2003:30-31).

Como bem colocou o general Rocha Paiva, não há uma conceituação formal da estratégia da presença nos manuais doutrinários da Força Terrestre (Paiva, 2000:13). No entanto, a crença de que foi a presença militar em todo território nacional que dissuadiu a incursão de corsários estrangeiros durante a Colônia e o fracionamento do Império territorial português após o processo de independência, além de contribuir para pacificação das revoltas internas no período Regencial e para a "garantia da lei e da ordem" na atualidade (Paiva, 2000:14), é um dos traços mais perenes da cultura estratégica do Exército.

A crença de que a presença militar garantiu a integridade territorial do Brasil é um dos principais "deslizamentos simbólicos" a partir dos quais o Exército brasileiro constrói suas percepções sobre a Amazônia ${ }^{69}$. Esta

Venezuela; pelo lado brasileiro, as regiões Norte do Amapá e Pará e Leste de Roraima. De acordo com a análise conjuntural do Exército, essas áreas estratégicas caracterizam-se pelos seguintes aspectos: a) possibilidade de nações lindeiras exercerem pressões no campo militar, por meio de ameaças aos pontos mais sensíveis da fronteira, em apoio a outros países sul-americanos em eventual conflito armado envolvendo o Brasil; b) possibilidade de participação brasileira para a resolução pacífica de contenciosos territoriais com implicações para os interesses nacionais; c) possibilidade de extensão de movimentos armados (guerrilhas), de origem política ou não, ao território nacional; d) permeabilidade do território nacional em face dos ilícitos transnacionais (particularmente o contrabando e o narcotráfico), podendo gerar reflexos para as relações internacionais; e) existência de pressões e possibilidade de intervenção estrangeira sob o patrocínio de interesses internacionais diversos, calcada na argumentação de proteção ao meioambiente e aos direitos das minorias indígenas (Brasil, 2006).

${ }^{69}$ Celso Castro e Adriana Souza desconstroem o mito de que a soberania sobre a Amazônia foi assegurada pela presença militar. De acordo com os autores, a presença de unidades do Exército "luso-brasileiro" na região não só é bem tardia, como se limita a uma faixa estreita da atual Amazônia. Em 1822, por exemplo, apenas três regimentos de infantaria e um de cavalaria guarneciam toda a região. 
crença baseia-se nas obras de autores como Nelson Werneck Sodré e Oliveira Viana que atribuem um sentido militar à colonização portuguesa:

O fato é que a ocupação, o povoamento, a produção, revestir-se-iam de um caráter guerreiro que o meio impunha. Durante o período colonial escreve Oliveira Viana - a conquista da terra apresenta, por isso, um caráter essencialmente guerreiro. Cada latifúndio desbravado, cada sesmaria povoada, cada curral erguido, cada engenho 'fabricado' tem, como preâmbulo necessário, uma árdua empresa militar. Do norte ao sul, as fundações agrícolas e pastoris se fazem com espada na mão. Não se pode tratar da fábrica ali - diz um cronista do século II, Frei Leonardo Oros - senão com a foice nesta mão e a espada na outra (...) A empresa de ocupação e povoamento era uma empresa militar inequívoca, revestia-se necessariamente de um sentido militar, e não podia deixar de ser assim. Os particulares estavam, dessa forma, sujeitos às eventualidades da luta armada e não apenas por força de disposições da legislação vigente, mas por força de suas próprias necessidades, das exigências do meio (Sodré, 1968:24-25).

Do "sentido militar" da colonização deriva a idéia de que a ação de presença por si só é uma estratégia militar ${ }^{70}$. No que concerne à Amazônia, a presença militar é tida como uma estratégia eficaz para induzir o povoamento, inibir a ação de atores transnacionais não públicos e garantir a ordem pública ${ }^{71}$ na região. A consecução da estratégia da presença exige

${ }^{70}$ Alguns oficiais, como Paiva, pensam que: "A existência de unidades militares e os papéis por elas desempenhados, seja na linha de fronteira, seja nos espaços vazios do interior, ou mesmo em núcleos populacionais, transmitem uma clara mensagem dissuasória, pela demonstração da vontade de manter a posse da terra, assegurar sua integridade e a paz interna. Sendo assim, a Presença deve ser considerada como uma ação estratégica incluída na Estratégia da Dissuasão (Paiva, 2000:13)".

${ }^{71}$ A Doutrina Militar de Defesa publicada em 2007 regulamenta a atuação das Forças Armadas na manutenção da ordem pública: "6.4.1 A atuação das Forças Armadas na garantia da lei e da ordem, por iniciativa de quaisquer dos poderes constitucionais, possui caráter excepcional, episódico e temporário. Ocorrerá de acordo com as diretrizes baixadas em ato do Presidente da República, após esgotados os instrumentos destinados à preservação da ordem pública e da incolumidade das pessoas e do patrimônio; 6.4.2. A decisão presidencial para o emprego das Forças Armadas nessa situação poderá ocorrer diretamente por sua própria iniciativa ou por solicitação dos chefes dos outros poderes constitucionais, representados pelos Presidentes do Supremo Tribunal Federal ou da Câmara dos Deputados; 6.4.3. A diretriz presidencial que autoriza e formaliza esse 
das Forças Armadas a execução de tarefas que não são de natureza militar, mas às quais se atribui um valor militar quando realizadas no âmbito da estratégia.

A Comissão Estratégica de Instalação de Linhas Telegráficas do Mato Grosso ao Amazonas ou Comissão Rondon, como ficou mais conhecida, exemplifica bem o tipo de tarefa desempenhada pelos militares brasileiros para a consecução da estratégia da presença. À construção da linha telegráfica, uma atividade eminentemente técnica, atribuiu-se um significado político e estratégico: expandir a autoridade do Estado sobre a vasta região noroeste do Brasil.

Todd Diacon (2006) faz uma instigante descrição da Comissão Rondon mostrando todo o esforço do patrono da arma de Comunicações em realizar cerimônias diárias de hasteamento da bandeira, execução do hino nacional etc. Esses rituais cívicos, segundo o autor, procuravam incutir nos funcionários da linha telegráfica e na população local, indígena e nãoindígena, um "sentimento de brasilidade".

Hoje vemos a atitude de Rondon revivida pelos oficiais que comandam os Pelotões Especiais de Fronteira. A realização de cerimônias cívicas nestas unidades, que atuam como um "pólo de colonização", prestase aos mesmos propósitos de Rondon.

No romance baseado em fatos reais, Pelotão de Fronteira, o personagem principal da estória, tenente Brácio, usa todos os expedientes que estão ao seu alcance para tornar os habitantes da ficcional Curi-Curi, nascida no entorno do $10^{\circ}$ Pelotão de Fronteira, cidadãos comprometidos com o Estado brasileiro. Todas as manhãs, à exceção dos domingos, a bandeira nacional era hasteada em Curi-Curi ao som do Hino Nacional cantado pelos soldados que, como sempre ocorria, entravam em forma

emprego será transmitida diretamente ao Ministro de Estado da Defesa e estabelecerá a missão, as condicionantes do emprego, os órgãos envolvidos e outras Informações necessárias; 6.4.4. Compete ao Ministério da Defesa tomar as providências necessárias à ativação e à implementação do emprego das Forças Armadas, bem como controlar e coordenar suas ações, inclusive com respeito aos componentes dos demais órgãos não integrantes da sua estrutura (Brasil, 2007a)". 
com a frente voltada para o grande mastro. O tenente Brácio comandava "Descansar" e dizia: "Bom dia Pelotão", ao que os militares respondiam em coro: "Bom dia meu Tenente", um procedimento que não era próprio do Exército brasileiro, mas assistido por Brácio numa guarnição colombiana e introduzida por ele ali no $10^{\circ}$ Pelotão de Fronteira. Após o canto do hino, que era entusiasticamente acompanhado pela população civil, o Pelotão executava alguns movimentos de "Ordem unida" e desfilava, liderado pelo sargento, em continência a seu comandante (Potyguara, 2006:45).

Além de comandar cerimônias cívicas, Brácio cuidava também da limpeza das vias públicas, gerenciava a produção de alimentos no Pelotão, socorria os civis doentes, administrava os conflitos entre os moradores da pequena vila, organizava bailes e abençoava a união de jovens casais apaixonados. Em suma, fazia às vezes do prefeito, do comerciante, do delegado, do juiz, e, em algumas ocasiões, do padre. Quando deixou o comando do $10^{\circ}$ Pelotão, foi substituído pelo tenente Schultz, natural de Santa Catarina, casado com uma filha de colonos alemães, que já se dispusera a ajudar a professora na escola mantida pelo Pelotão. No epílogo da estória, enquanto assiste a um casamento triplo, cheio de simbologia, o novo comandante de Curi-Curi define com poucas palavras a percepção que o Exército tem de sua missão na fronteira amazônica:

É isso que faz a grandeza deste país. Um crioulo, baiano, casa com uma cabocla, um caboclo com uma índia e um branco com uma cabocla. Todos ficarão aqui e terão filhos ... Assim vai-se construindo uma pátria ... (Potyguara, 2006: 191-192).

Na nada idílica Vila de Rondônia, atual Ji-Paraná, o capitão da engenharia Marseno também tenta estabelecer a autoridade estatal e "construir a nação". Assim como Brácio, Marseno desempenha com desenvoltura ações cívico-sociais, reconstrói uma escola abandonada, socorre os doentes, e, num dos lances mais pitorescos de seu comando, tenta impedir o casamento de dois habitantes da vila considerados por ele "debilóides". Bem menos comedido e paternalista que o fictício tenente Brácio, o tenente Marseno cumpre sua missão numa localidade dominada por seringalistas, grileiros de terra e políticos oportunistas que fazem suas 
próprias leis. O tenente enfrenta os poderosos locais, deixando claro que, com a sua chegada, o governo federal assumiu o controle da Vila: ${ }^{72}$

Esses pobres coitados, simples e humildes, necessitando do emprego para sobreviverem, suportavam isso tudo, para não dizer da agressão corporal que muitas vezes eram vítimas. Hoje, o quadro se modificou completamente. O Exército sempre foi um Poder Moderador e tem feito valer o império da justiça quando chamado a intervir. O Exército aqui é representado pelo $5^{\circ}$ BEC e este pela $1^{\text {a }}$ Companhia Especial de Construção.

Essa gente humilde que continua trabalhando para o Governo Federal, desta feita sob a égide do Exército, sente neste o apoio, proteção e o moral para fazer valer a responsabilidade de cada um, dando-Ihes oportunidade de ser gente com dignidade, que deve respeitar os outros, porém, ser também respeitados (Martins, 1971:236).

Por desempenharem funções que extrapolam as lides normais da caserna, e remetem ao imaginário que se construiu acerca da atuação dos portugueses na Amazônia, é comum os oficiais que servem em unidades de fronteira ou em Batalhões de Engenharia de Construção compararem o papel desempenhado pelo Exército na região com papel atribuído aos colonizadores:

${ }^{72}$ O livro de memórias do coronel Marseno, Amazônia e Nós, é um contraponto interessante para o livro de memórias do general Potyguara, Pelotão de Fronteira. $\mathrm{Na}$ ficção do general Potyguara a relação entre os diferentes atores sociais que vivem na vila de Curi-Curi, índios, caboclos, comerciantes colombianos, soa excessivamente harmônica; já nos relatos do coronel Marseno os conflitos são mais explicitados. É certo que o Brasil e suas Forças Armadas mudaram muito desde a época em que o coronel Marseno bradava aos políticos locais da Amazônia que ali o representante da lei era ele; por isso, é compreensível o tom mais ameno do texto do general Potyguara. Mas as diferenças entre os dois relatos não se resumem às mudanças nas relações entre civis e militares engendradas pela redemocratização do país; é possível vislumbrar uma mudança no sentido da presença militar na Amazônia. De uma ação de presença ostensiva e truculenta com a população e com a natureza, representada pelas grandes manobras militares e pela construção de estradas, como a transamazônica, a instituição mudou para uma ação de presença seletiva buscando adequar o perfil das obras realizadas pelos militares às necessidades da população local. As obras do Programa Calha Norte são representativas da nova fase da presença militar na Amazônia. 
A presença militar na Amazônia está historicamente relacionada com a sua ocupação pelo colonizador e construção dos fortes. A estratégia utilizada pelos portugueses previa a permanência dos militares que prestavam o serviço militar na guarnição, após a sua saída da caserna, sendo prevista uma compensação a título de estímulo. Começavam assim, a surgir os núcleos populacionais que, atualmente, se observam distribuídos ao longo dos rios e, até mesmo, em áreas interiores da região amazônica. O Exército brasileiro permanece, ainda hoje validando a mesma estratégia, quando, até recentemente, utilizou-se de Colônias Militares, e agora, através da contínua implantação de Pelotões Especiais de Fronteira (Stevaux, 1996:41).

Em conseqüência, o Alto Rio Negro ainda pode ser tratado como "colônia" e o colonizador, representante legítimo do governo, seria o Exército Brasileiro. A razão é simples. A história mostra que o Exército foi a peça fundamental nas ações governamentais que atingiram decisivamente o Alto Rio Negro (Januário, 1996:55).

Os trechos acima revelam que o Exército vê na estratégia de ocupação territorial portuguesa a gênese da estratégia da presença brasileira. Ainda que, historicamente, a tese de que os portugueses asseguraram a soberania sobre a Amazônia através da ocupação "militarcolonizadora" da região não se sustente, o fato é que a crença dos militares brasileiros neste "mito" explica em parte a longevidade da estratégia da presença.

A teoria da organização ${ }^{73}$, também ajuda a explicar a persistência

${ }^{73}$ Há uma discussão no campo das relações civis-militares acerca da natureza da profissão militar na atualidade. Charles Moskos (1977), inspirado num argumento inicialmente exposto por Janowitz, afirma que as Forças Armadas distinguem-se entre as que têm um perfil institucional, ou seja, aquelas que valorizam os aspectos militares da profissão em detrimento de questões particulares (como tempo livre, vida em família, salário, e mercado de trabalho fora da caserna), e as que têm um perfil ocupacional, ou seja, aquelas em que os militares preferem as especializações que podem ser exercidas também fora da caserna. Para Moskos, as Forças Armadas estariam paulatinamente mudando seu perfil de institucional para ocupacional; por isso, elas estariam cada vez mais parecidas com organizações privadas. Soeters e Recht (1998) testaram esta hipótese entrevistando militares de dezoito países e concluíram que nos países latinos, as Forças Armadas devem ser consideradas instituições e não organizações. No caso brasileiro, e especialmente no que diz respeito à Amazônia, percebemos que os militares valorizam, e 
da estratégia da presença. March, Sproull e Tamuz (1991) chamam a atenção para um aspecto importante da dinâmica interna das Forças Armadas. As organizações aprendem por meio da história. Instituições militares que tem poucas experiências de combate para se pautar, tendem a explorar os eventos históricos de que dispõe intensivamente. Fazer isso implica prestar atenção a todos os aspectos da experiência e desenvolver mais interpretações sobre o fato. Neste sentido, acreditamos que o Exército brasileiro recorre com tanta freqüência à estratégia portuguesa na Amazônia porque conta com poucas experiências históricas que possam servir como matéria-prima para a elaboração de uma estratégia militar para a região. Basta lembrar que o Brasil desde que se tornou independente, travou poucas guerras para preservar a integridade territorial do país ${ }^{74}$.

Outra característica organizacional das Forças Armadas merece atenção no que diz respeito à longevidade da estratégia da presença. De um modo geral, as organizações tendem a repetir as experiências prévias se estas são consideradas positivas (March; Sproull; Tamuz, 1991:02). Como o Exército brasileiro entende que a presença militar foi eficaz ao longo da história política brasileira, tende a revalidar o uso dessa estratégia, o que fica claro no trecho citado acima.

Se a teoria da organização nos ajuda a entender a persistência da estratégia da presença, é preciso recorrer a outras abordagens teóricas para compreender a principal inovação doutrinária do Exército brasileiro nas últimas décadas: a estratégia da resistência.

são valorizados por seus pares, quando servem na região por questões essencialmente institucionais. O prestígio está relacionado às agruras da vida na selva, que exige do militar e de seus familiares vários sacrifícios, e ao significado atribuído à missão: contribuir para a manutenção da integridade territorial do Brasil. Fazemos esta digressão para esclarecer que quando nos referimos à teoria da organização, não estamos assumindo que as Forças Armadas brasileiras tem um funcionamento similar ao de uma organização privada.

${ }^{74}$ Refiro-me à Guerra da Cisplatina e à Guerra do Paraguai, ambas travadas no século XIX. 


\subsection{A estratégia da resistência}

Como já foi dito anteriormente, o Exército, desde o final da década de 1970, dedica-se à elaboração de uma doutrina militar genuinamente brasileira. As mudanças percebidas na ordem internacional durante este período histórico explicam, em parte, esta decisão doutrinal. O abrandamento das tensões leste-oeste, a política exterior do governo Carter (1976-1980) para a América do Sul (cujo eixo era a defesa dos direitos humanos e a campanha pela não-proliferação militar na região), e a postura dos Estados Unidos durante a Guerra das Malvinas contribuíram para mudar a percepção das Forças Armadas acerca da dependência doutrinária e tecnológica do Brasil em relação aos norte-americanos:

Uma Doutrina Militar sólida exige a experiência de muitos conflitos, a consciência nacional de que a guerra é um acontecimento sempre possível e inopinado, e, sobretudo, a independência tecnológica (...) Assim, nações ricas, tidas como potências militares, que pagaram elevados preços para desfrutarem desse estado, dispõem de volumoso cabedal de experiência, traduzido nos preceitos de suas doutrinas de guerra, alicerçadas em documentos guardados nos escaninhos de seus arquivos históricos, que relataram os casos ocorridos nos numerosos conflitos armados de que participaram, isoladas ou em alianças com outras nações. E, com tais recursos puderam coligir e fundamentar os princípios normativos da conduta nacional na contingência de ter que enfrentar uma nova guerra, mesmo global; levando em linha de conta, naturalmente, o estágio de riqueza, a prosperidade, a independência do seu parque industrial e a capacidade energética, ou estado emocional de seu povo. Tais nações ricas, experientes, extravasam influências e ensinamentos doutrinários às mais pobres e inexperientes. Estas, em estágios inferiores de progresso, de parcos recursos financeiros e sem a necessária ilustração histórica, conseqüência direta dos poucos casos vividos, sentem a necessidade de absorver tecnologia das mais experientes, aceitando missões militares estrangeiras, por meio das quais perfilam princípios das escolas importadas, às vezes sujeitas a verem violados seus segredos de Estado (Duarte, 1984:121).

A citação acima revela algumas das preocupações castrenses com a dependência doutrinária. Percebe-se que a pouca experiência de combate dos brasileiros é tida como uma das causas dessa dependência. $E$ 
depender de outro país para definir os próprios princípios doutrinários deixa o Brasil, em certa medida, vulnerável. Para modificar tal situação, as Forças Armadas foram buscar na história militar brasileira elementos que pudessem auxiliá-las a criar uma doutrina militar genuinamente nacional:

De tradutores ou copistas de manuais estrangeiros, alcançamos o estágio de formuladores de um corpo de doutrina genuinamente nacional, adotando soluções originais para nossos problemas militares. Aliás, a criatividade é uma característica marcante de nosso povo. Por meio dela resolvemos todos os conflitos internos e externos de nossa história. Foi assim em Guararapes (1648-1649), no Rio Grande do Sul (1762-1775), nas campanhas da Bacia do Prata, no século XIX, etc. A história militar nos parece ditar o futuro de nossa doutrina. A forma como combatemos um inimigo muito mais forte, seja em Guararapes, seja na guerra de guerrilha, na Campanha Gaúcha, é uma indicação do que devemos fazer no ambiente amazônico. Por isto, a "Resistência" preconizada na Doutrina GAMA, (...) parece-nos a melhor e mais criativa solução estratégica para enfrentar esta situação (Boaventura, 2001:56).

De um modo geral, os textos escritos por militares que tratam da estratégia da resistência, citada acima, afirmam que ela foi criada como resposta às pressões sofridas pelo Brasil em razão de temas que ocupam a agenda internacional como proteção ambiental e defesa dos direitos humanos, dos indígenas em particular, no caso da Amazônia. Traduzindo a justificativa dos fardados para linguagem das relações internacionais, mais precisamente para linguagem do neorealismo, a estratégia da resistência, à primeira vista, seria uma resposta do Estado brasileiro aos constrangimentos impostos pelo sistema internacional. Mas se nós analisarmos com mais cuidado como esta resposta foi construída, e por que esta estratégia militar e não outra foi escolhida pelo Exército brasileiro, é possível traçar um retrato mais nítido dessa opção estratégica e das suas possíveis interconexões com as relações entre os civis e os militares no Brasil.

A estratégia da resistência foi desenvolvida por oficiais do Exército que foram servir no Comando Militar da Amazônia em meados da década de 1990 e caracteriza-se pelo "desenvolvimento de ações militares em um 
conflito prolongado, de caráter restrito, na maioria das vezes de baixa intensidade, onde normalmente empregam-se táticas e técnicas de guerrilha (Brasil, 2006)", e será empregada pelo Brasil caso sejamos invadidos por outro país ou por uma força multinacional possuidora de um poder militar incontestavelmente superior (Abreu, 2003:26). Contudo, apesar do combate de resistência estar fundamentado no intenso emprego de ações típicas de guerrilha, não se pretende transformar a força regular numa força de guerrilha, o que seria um retrocesso inconcebível e prejudicial para o desenvolvimento da campanha (Pinheiro, 2005).

Sobre o incontestável poderio militar, argumenta-se que nenhum país tem equipamento que possa desafiar a total superioridade da "superpotência solitária"75, e nem os desenvolverá devido aos tremendos custos e porque tal desenvolvimento o colocaria em "rota de colisão" com o poderoso inimigo antes que pudesse alcançar paridade. A resistência parte do pressuposto que a condição de superpotência, no entanto, não a torna inexpugnável, já que a superioridade militar pode levar a um excesso de confiança e, conseqüentemente a um desastre (Abreu, 2003:26-29).

Para enfrentar uma superpotência, a estratégia da resistência considera o método da ação indireta preconizado por Sun Tzu. O general Alberto Cardoso apresenta uma interpretação interessante dos ensinamentos de Sun Tzu para o Exército brasileiro, utilizando o exemplo de um país fictício.

Caso o estrategista chinês tivesse que preparar a defesa de uma rain forest (Cardoso utiliza o termo internacional para designar as florestas tropicais) que ocupa mais de um terço da superfície do país DELTA, possui uma imensa biodiversidade, quantidade de água doce e riquezas minerais, ele provavelmente idealizaria uma estratégia de ação indireta. Nessa estratégia o emprego clássico de forças militares ocorreria somente na última fase pelas seguintes razões: 1- a região é emblemática para o forte sentimento nacionalista do povo e uma ameaça a ela potencializaria a coesão entre o governo, o povo e as Forças Armadas; 2- as Forças

\footnotetext{
${ }^{75}$ Samuel Huntington cunhou esta expressão para referir-se aos Estados Unidos no pósGuerra Fria.
} 
Armadas de DELTA tem muitos generais totalmente afeitos à estratégia não ortodoxa desenvolvida para a defesa da região; 3- o clima, vegetação, espaços e vias de comunicação (na quase totalidade rios plenos de meandros etc.) favorecem as forças aclimatadas e rústicas que os conhece bem; 4- os oficiais e praças de DELTA são muito mais bem treinados naquele ambiente do que quaisquer outros profissionais estrangeiros.

As circunstâncias anteriores equilibrariam os poderes relativos de combate, o que remete para a alta probabilidade de uma guerra longa de desgaste que, em tese, beneficiaria DELTA. O inimigo externo que deseja conquistar a rain forest também utilizaria uma estratégia indireta que: 1cerceie DELTA de explorar os recursos naturais da região; crie condições para a satanização de DELTA, no momento oportuno, visando a obter a liberdade de ação para uma eventual rápida ocupação militar de áreas estratégicas, e a facilitar a urdidura de uma coalizão para essa guerra.

Para se contrapor à estratégia do inimigo externo, DELTA deve: 1fortalecer a "Lei Moral", que, de acordo com a definição de Sun Tzu, leva o povo a ficar em completo acordo com seu governante, de maneira a seguilo sem temor pela vida, sem se intimidar por qualquer perigo; 2- anteciparse à satanização, selecionando os temas que sensibilizam a opinião pública internacional, como meio ambiente e população indígena, e dando-Ihes um tratamento apropriado; 3- aliar-se aos Estados vizinhos que comungam a mesma hipótese de conflito, otimizando o antigo pacto regional relativo à exploração sustentável dos recursos e apensar-lhe o tema indígena; 4trabalhar em parceria com as organizações não-governamentais sérias, sem interesses mascarados (Cardoso, 2005:59-61).

A análise de Cardoso deixa entrever que uma intensa preparação política antecede o embate militar "na luta do fraco contra o forte" concebida por Sun Tzu. Se bem executada, a ação indireta pode postergar ou até mesmo impedir o conflito armado. As propostas do general para o país Delta lembram algumas iniciativas do governo e das Forças Armadas brasileiras para a região amazônica como a revitalização do Tratado de Cooperação Amazônica através da criação da Organização do Tratado de Cooperação Amazônica e a realização de ações cívico-sociais. 
A estratégia da resistência em sua fase militar também oferece alguns elementos interessantes para a reflexão. Ainda que se argumente, com razão, que esta estratégia inspira-se na experiência de resistência de outros países e povos - a comparação com o método utilizado pelos vietnamitas para derrotar os norte-americanos é inevitável - os estrategistas brasileiros localizam sua gênese em experiências militares do período colonial, procurando, desta forma, resguardar o caráter "nacional" da estratégia. A ênfase dada à participação dos indígenas na consecução da estratégia de resistência também remete a esta preocupação.

Buscar os fundamentos da resistência na história militar lusobrasileira faz-se necessário porque nem mesmo as lições da Guerra do Vietnã, a principal referência histórica de uma bem sucedida guerra de resistência, podem ser aproveitadas integralmente pelo Brasil. As diferenças entre a Amazônia brasileira contemporânea e o Vietnã da década de 1960 são de diversas ordens, a começar pela fisiografia das duas regiões. No âmbito político é importante lembrar que as principais motivações do povo vietnamita para resistir foram o desejo de unificação do país, a vontade de expulsão dos estrangeiros e a ideologia, habilmente utilizada por lideranças carismáticas como Ho Chi Minh e o general Giap ${ }^{76}$. Sob uma perspectiva histórica, a análise das duas guerras travadas no Vietnã contra potências estrangeiras, após a Segunda Guerra Mundial, revela que o caso vietnamita é consideravelmente diferente de qualquer cenário prospectivo possível para o Brasil, diante da diversidade de atores e circunstâncias envolvidos, especialmente as diferenças culturais. Do ponto de vista militar, o fosso tecnológico que separa o Brasil de uma eventual força multinacional é bem maior atualmente do que era na época em que o Vietnã resistiu aos seus inimigos (Abreu, 2003: 28). Resumindo, embora sejam úteis sob o aspecto metodológico, os procedimentos doutrinários que tiveram êxito no Vietnã podem não funcionar em outros teatros de operação.

\footnotetext{
${ }^{76} \mathrm{O}$ general Giap é uma grande fonte de inspiração para os estrategistas da resistência brasileiros, ver: Forjaz (1999) e (2000).
} 
Por isso, é no repertório de experiências militares do Exército brasileiro que os oficiais que elaboraram a estratégia da resistência buscam os elementos para construí-la. As fontes de inspiração mais citadas pela estratégia da resistência são as campanhas "luso-brasileiras" para expulsar os corsários ingleses, franceses e holandeses que incursionavam pelo litoral da colônia portuguesa à busca de riquezas. Pedro Teixeira, o "Conquistador da Amazônia" na mitologia militar, é o precursor do uso de "técnicas de guerra de guerrilhas" no Brasil colonial. De acordo com o discurso oficial do Exército, Teixeira foi o primeiro "chefe militar" ${ }^{77}$ a utilizar "táticas de guerrilha" para derrotar os inimigos. O ponto mais interessante desta narrativa é a forma como as forças luso-brasileiras aprenderam essas táticas: com um dos inimigos, os índios tupinambá ${ }^{78}$.

No imaginário do Exército, os tupinambá ameaçavam a conquista portuguesa de Belém e de outras localidades litorâneas entre esta cidade e São Luís, com suas "técnicas de guerra de guerrilha". Para combatê-los, Pedro Teixeira instruiu suas tropas a utilizar os mesmos métodos dos inimigos, conseguindo desta forma derrotá-los. Desta experiência histórica, alguns oficiais do Exército brasileiro tiram a seguinte lição: guerrilha se combate com guerrilha (Pinheiro, 2005).

Pedro Teixeira também teria sido o precursor da "campanha de emboscadas" que notabilizou Antônio Dias Cardoso na Insurreição Pernambucana do século XVII. Na campanha que expulsou os holandeses

${ }^{77}$ É importante esclarecer que a idéia atualmente muito difundida pela caserna de que Pedro Teixeira era um militar que comandou um exército na Amazônia não se sustenta historicamente. Pedro Teixeira em verdade era um vassalo do rei da Espanha e servia aos interesses dos Habsburgo na América (Castro; Souza, 2006:48). A construção do Pedro Teixeira mítico só é possível quando se acredita que a colonização do Brasil foi uma empresa militar: "Organizando-se no meio da selvageria, o domínio defende-se a si mesmo. Assediado por todos os lados, é forçado a constituir-se militarmente. Forma, então, dentro dos seus muros, um pequeno exército permanente - pronto, ágil, mobilíssimo, talhado à feição do inimigo (Viana, 2002:979)". O inimigo em questão é o indígena, com o qual, de fato, o colonizador português contou para defender seus domínios.

${ }^{78}$ É necessário uma enorme licença poética para atribuir aos tupinambá o uso de "táticas de guerrilha", um conceito que esses guerreiros certamente não conheciam. 
da região nordeste brasileira, Dias Cardoso comandou pequenas frações que atuavam descentralizadas em ações caracterizadas pela surpresa, as chamadas emboscadas. O Exército brasileiro traça um paralelo entre as missões desempenhadas por Dias em Pernambuco e as desempenhadas pelas tropas de comandos e forças especiais nos Exércitos modernos (Exército Brasileiro, 2007h).

O paralelo estabelecido entre Dias Cardoso e as Forças Especiais é mais uma construção mítica do Exército que não encontra respaldo na história. Os holandeses se estabeleceram na Bahia em 1624, durante o período da União Ibérica. Em 1640, Portugal restabeleceu sua autonomia. A população local que resistia aos holandeses há duas décadas supôs que, uma vez autônoma, a Coroa portuguesa a auxiliaria. No entanto, o governador do Brasil, Jorge de Mascarenhas, Marquês de Motalvão, estabeleceu entendimentos com Nassau e, em junho de 1641, Portugal e Holanda concordaram em celebrar um tratado de aliança ofensiva e defensiva contra os espanhóis, e um armistício de dez anos, quanto às respectivas colônias.

Segundo Nelson Werneck Sodré, a expulsão dos holandeses do nordeste só foi possível pela tenacidade da população local que jamais compactuou com os batavos e lutou "dentro de suas possibilidades, durante todo tempo, constituindo-se no fundamento da resistência, do primeiro ao último instante". Os senhores de engenhos, após a derrota inicial, pactuaram com os holandeses, participando mesmo dos órgãos de representação criados por estes. Eles mudaram de postura somente quando seus interesses foram contrariados, buscando, então, apoio nos populares. Os portugueses, por sua vez, somente forneceram à resistência os recursos necessários para sustentar a luta quando as forças locais já haviam alcançado vitórias decisivas (Sodré, 1968:39).

Logo, não é correto inferir que Dias Cardoso, quando comandou as emboscadas, estivesse cumprindo uma missão que lhe foi atribuída pelo poder público, tal qual as forças especiais dos exércitos modernos.

Já no século XX, José Plácido de Castro, um ex-estudante da Escola Militar de Porto Alegre que lutou contra as tropas federais na Revolução 
Federalista (1893-1895), "validou" o uso de "táticas de guerrilhas" na Amazônia quando derrotou o Exército boliviano no Acre, adaptando para o ambiente amazônico as técnicas que aprendera com os revoltosos sulinos.

Nas três experiências citadas como fontes de inspiração para o combate de resistência na Amazônia um aspecto chama a atenção. Nem Pedro Teixeira, nem Dias Cardoso, nem Plácido de Castro comandaram Exércitos regulares lutando de forma irregular. A expedição de Pedro Teixeira era composta por portugueses, franceses, homens nascidos na América e índios, que não constituíam um Exército, até porque as Forças Armadas tal como conhecemos hoje ainda não existiam na época em que Pedro Teixeira viveu (Castro; Souza, 2006). Em Pernambuco, foram os colonos que organizaram a resistência aos holandeses (Sodré, 1968). E, por fim, as tropas comandadas por Plácido de Castro eram compostas por seringueiros e não por militares.

Ainda que não seja um fato muito citado quando se fala em estratégia da resistência, o Exército brasileiro já utilizou técnicas de "guerra irregular" quando combateu a guerrilha do Araguaia na década de 1970. Num livro sobre o conflito, o autor, Hugo Studart, relata algumas das técnicas utilizadas nesta ocasião:

Preliminarmente, vale esclarecer que na Terceira Campanha cerca de 30 guerrilheiros, portanto, a maior parte, foi morta pelas tropas especiais de pára-quedistas e de guerra na selva. Eram tropas regulares, ainda que estivessem entrando na mata em situação nãoregular, sem uniforme e com identidade falsa. Mas não tinham qualquer relação direta com a repressão política, nem eram membros da comunidade de informações. Eram simplesmente soldados atuando como partisans. Contudo, é essencial lembrar que esses soldados estavam entrando em combate sem muita disposição de fazer prisioneiros. No primeiro encontro que tiveram com o inimigo - Zé Carlos e seu grupo - esses teriam reagido à ordem de prisão e tentado sacar a arma (...) No segundo encontro, com Sônia, a guerrilheira reagiu à ordem de prisão (...) Esse segundo caso ajudou os comandantes militares a convencer a tropa enviada à selva que os guerrilheiros não estavam dispostos a se entregar. Seriam todos uns "fanáticos", como eram definidos na ocasião. E qualquer vacilo diante de um guerrilheiro fanático, poderia ser fatal. A partir desses episódios, 
as tropas regulares passaram a entrar em combate com a disposição de atirar para matar (Studart, 2006:256)".

Voltando ao imaginário construído em torno do legado de Pedro Teixeira para o Exército brasileiro, é possível inferir que a lição "guerrilha se combate com guerrilha", está mais relacionada à experiência do Exército no Araguaia, do que na mitificada atuação de Pedro Teixeira na Amazônia. Nas operações militares realizadas para testar a estratégia da resistência, é possível identificar métodos que foram utilizados pelos militares do Exército e pelos guerrilheiros na campanha do Araguaia ${ }^{79}$.

$\mathrm{Na}$ Operação Marajó, ocorrida nos meses de outubro e novembro de 2001 na llha de Marajó no Estado do Pará. ${ }^{80}$ A exemplo do que fizeram o Exército e a Força Aérea na terceira campanha do Araguaia (Studart, 2006:163), a Força de Resistência combateu sem o uso de uniformes. Este método dificulta a sua identificação por parte da Força Invasora e, principalmente facilita o trânsito e a integração com a população local (Exército Brasileiro, 2005c).

Uma semelhança com os métodos utilizados pelos guerrilheiros brasileiros durante a ditadura militar é a confecção de cartazes informando a população sobre as verdadeiras intenções da Força Invasora. Desta postura apreende-se que o invasor da Amazônia utilizará pretextos para invadir a região. Os cartazes reproduzidos abaixo foram colocados nos pontos de maior circulação de pessoas na vila de Breves, com o objetivo de alertar a Força Invasora a deixar o país, além de estimular os habitantes locais à não cooperarem com o inimigo (Exército Brasileiro, 2005c).

\footnotetext{
${ }^{79} \mathrm{O}$ artigo do general Pinheiro (2005) mostra como a experiência do Exército no combate à guerrilha do Araguaia pode ser aproveitada na construção da estratégia da resistência.

${ }^{80}$ A Operação Marajó teve como finalidades aprimorar o Sistema de Mobilização do Exército no Pará e colher ensinamentos sobre convocação de reservistas para atuar na estratégia de resistência (Exército Brasileiro, 2005b).
} 

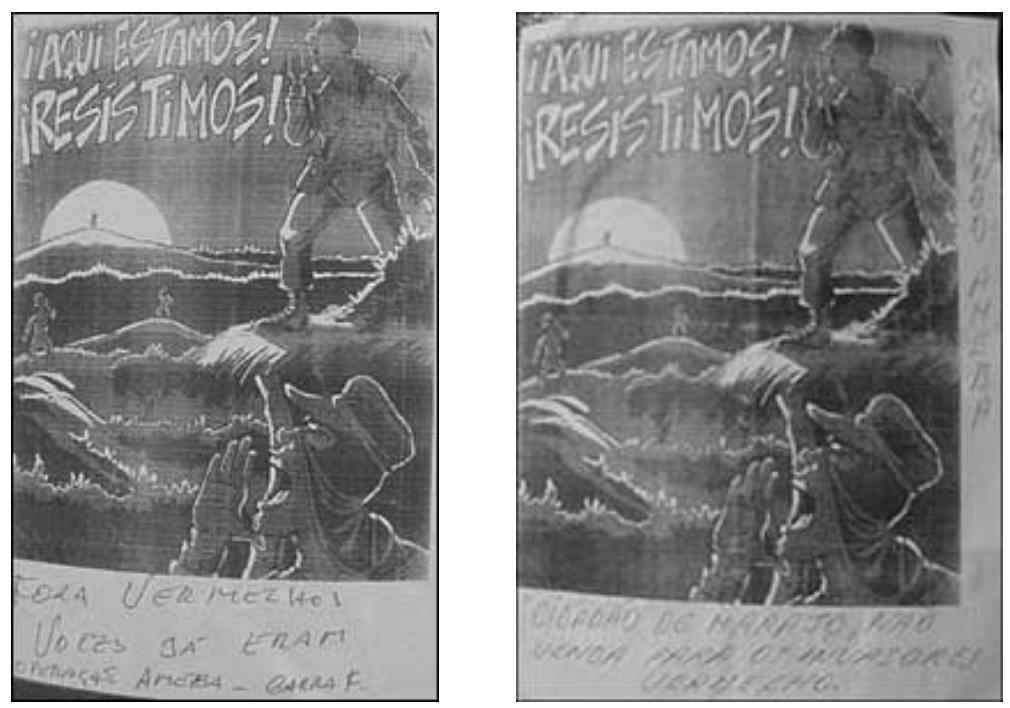

Figuras 5 e 6 - Cartazes da Força de Resistência ${ }^{81}$

Fonte: Exército Brasileiro (2005c)

Como já foi dito no primeiro capítulo, a estratégia da resistência depende muito dos civis. O apoio da população local, indígena ou não, é fundamental para o êxito de uma Força de Resistência brasileira:

Um dos preceitos básicos da aplicação da Estratégia da Resistência implica no comprometimento nacional com a causa amazônica. No âmbito da Força Terrestre, este comprometimento, deve ter início com a efetiva preparação dos Quadros para a compreensão e dimensionamento do seu emprego no Teatro de Operações (TO) amazônico, num ambiente de resistência. Esta preparação terá inclusive o cunho de operação psicológica voltada para o público interno, diretamente envolvido com a execução da estratégia desde a sua concepção atual até o seu desencadeamento num futuro clima de crise (Batista, 2001:30-31).

As operações militares realizadas na Amazônia nos últimos anos para testar e aperfeiçoar a estratégia da resistência valorizam muito o que o Exército chama de ações cívico-sociais, para tentar criar um clima de cumplicidade entre o Exército e a população local, tão importante para o sucesso da resistência. Via de regra, enquanto os infantes de selva e os

${ }^{81} \mathrm{O}$ cartaz à esquerda traz as inscrições: "Aqui estamos! Resistimos!". E "Fora vermelhos. Vocês já eram. Operação Ameba - Garra F". O cartaz à direita traz as inscrições: "Aqui estamos! Resistimos!". E "Cidadão de Marajó, não venda para os invasores vermelhos. Comando Ameba". 
especialistas das forças especiais se internam na selva para testar a estratégia, os profissionais da área de saúde do Exército prestam assistência médica e odontológica aos habitantes da área onde se realiza o exercício.

Esta atitude é bem diferente daquela que os militares tiveram quando tentavam capturar os guerrilheiros no Araguaia. Na década de 1970, a população local foi tratada com grande truculência pelas tropas federais. Sem o apoio da população, os militares não conseguiram capturar (ou abater) muitos guerrilheiros (Studart,2006:164).

Afora a realização de ações cívico-militares durante os exercícios de resistência, o Exército procura manter uma boa relação com os habitantes locais através dos tiros-de-guerra. O objetivo dos tiros-de-guerra é formar reservistas de $2^{\mathrm{a}}$ categoria aptos ao desempenho de tarefas no contexto de Defesa Territorial e Defesa Civil. A formação do atirador é realizada no período de 40 semanas, com uma carga horária semanal de 12 horas, totalizando 480 horas de instrução. Há um acréscimo de 36 horas destinadas às instruções específicas do Curso de Formação dos Cabos um terço desse tempo é direcionado para matérias relacionadas com ações de saúde, ação comunitária, defesa civil e meio ambiente (Verde Oliva, 2005).

Os tiros-de-guerra participam de ações comunitárias, como projetos com crianças e adolescentes em situações de risco social, campanhas de vacinação e de prevenção de enfermidades, recuperação e conservação de escolas públicas, entre outras. Para o Exército "os atiradores tanto se preparam para o desempenho de funções militares (têm um papel fundamental na defesa da Amazônia) como para a participação cotidiana no desenvolvimento dos municípios da Amazônia (Verde Oliva, 2005)".

De uma maneira geral, as ações cívico-sociais do Exército e a instalação de tiros-de-guerra na Amazônia são muito bem vistas pela população e pelas autoridades locais ${ }^{82}$. Contudo, não é possível afirmar

82 O Exército brasileiro em sua página na internet disponibiliza textos, áudios e vídeos de suas operações militares. Para maiores informações ver: 
que o apoio dos habitantes locais às ações assistencialistas do Exército signifique que os amazônidas apóiam a estratégia de resistência. Até porque a consecução dessa estratégia envolve alguns aspectos pouco divulgados, mas que merecem bastante atenção.

A estratégia da resistência prevê que, num primeiro momento, o país invadido reaja utilizando suas tropas de uma maneira convencional para em seguida desengajá-las progressivamente, passando de uma situação de guerra regular para uma efetiva guerra irregular (Abreu, 2003:31). Na fase de guerra irregular, os militares atuam como partisans, organizando a força de resistência. Esta Força é composta por militares e civis, sendo que os últimos podem atuar como informantes ${ }^{83}$, guias, etc.

É importante ressaltar que a guerra irregular, ou conflito assimétrico, como vem sendo chamado após as ações militares dos Estados Unidos no Afeganistão e no Iraque, é um conflito travado às margens das convenções do direito internacional, lembrando que uma força que combate guerrilheiros não é obrigada a tratá-los como combatentes legítimos, se não estiverem enquadrados nas situações previstas no direito internacional (Abreu, 2003:25). Neste sentido, a estratégia da resistência, coloca a população civil na linha de frente do conflito, sem, necessariamente, assegurar-Ihe a devida proteção do direito internacional. Por este motivo, Barry Posen afirma que a doutrina dissuasiva, seja ela voltada para o uso de armamentos nucleares, ou a que propugna a resistência ao invasor, torna os soldados especialistas em carnificina (Posen, 1984:50).

Além do apoio da população local, os manuais doutrinários que tratam da realização de operações militares na Amazônia apontam a necessidade do Exército aprender com os nativos as técnicas de sobrevivência na selva. Os nativos conhecem os alimentos regionais e os cursos dos rios. Como voluntários, eles podem servir como guias e rastreadores:

$<$ http://www.exercito.gov.br/03ativid/operacoes/indice.htm>.

${ }^{83}$ De acordo com o depoimento de habitantes de Breves até as crianças da região participam do Exercício de Resistência (Exército Brasileiro, 2005d). 
Individualmente, além da prática da orientação propriamente dita, que permitirá ao homem isolado a realização da navegação precisa para um determinado objetivo, deve ser incluída na MF a instrução de rastreador ou de interpretação de indícios. Essa instrução tem por objetivo habilitar o combatente a interpretar rastros ou indícios no interior da floresta, viabilizando uma perseguição, a identificação da presença do inimigo ou a prática das medidas de proteção contra a ação de outros rastreadores. A instrução do rastreador ainda se encontra em fase inicial de aplicação no âmbito do Comando Militar da Amazônia (CMA) e vem sendo observado que a experiência dos elementos regionais se constitui na principal fonte de assuntos a serem explorados nesta matéria (Batista, 2001:32).

A necessidade de aprender com os nativos para combater um possível invasor estrangeiro faz com que o Exército procure incorporar, cada vez mais, indígenas em seu efetivo: "Quando da seleção para o serviço militar inicial, priorizar a incorporação de jovens oriundos das comunidades indígenas, desde que voluntários e aprovados no processo de seleção (Brasil, 2003:04)".

A valorização da sabedoria indígena pelo Exército, contudo, não é apenas fruto de imposição doutrinária. $O$ fato é que o desempenho dos soldados de origem indígena nos exercícios de sobrevivência na selva fez com que os militares revissem algumas de suas visões acerca da cultura nativa. Os índios começaram a ser incorporados porque o Exército tinha grande dificuldade de recrutar pessoal entre os jovens urbanos da Amazônia. Eles resistiam a ficar num Batalhão de Infantaria no meio da selva. A alternativa foi recrutar os jovens locais. $O$ treinamento de guerra na selva que para os jovens urbanos é bastante penoso, para os índios é como férias; num curso que muitos têm dificuldade de concluir, dado o grau de exigência física, muitos índios chegam a engordar (Manso, 2005).

A maioria dos indígenas é incorporada nos chamados núcleos base $^{84}$. Os soldados do núcleo base servem no Exército durante oito anos e depois são dispensados. Alguns índios, no entanto, são efetivados pela força terrestre por possuírem habilidades específicas que são importantes

${ }^{84}$ Os índios não são obrigados a se alistar, mas podem fazê-lo voluntariamente. 
para o combate na selva, como ser um bom guia na mata, pilotar barcos à noite, ou ser elemento de ligação do Pelotão Especial de Fronteira com a comunidade indígena (Mélega, 2007).

A experiência relativamente recente dos índios no Exército nos ajuda a compreender como idéias e ações são mutuamente constitutivas na construção da cultura estratégica de uma força militar. Posto de outra forma, os serviços prestados pelos indígenas ao Exército no presente, fazem com que os militares mitifiquem a importância dos indígenas no passado, criando um ideário no qual Pedro Teixeira, o antecessor do Comandante Militar da Amazônia no discurso castrense, teria aprendido técnicas de guerrilha para defender a região amazônica com os índios tupinambá (Pinheiro, 2005).

$\mathrm{Na}$ próxima seção apresentaremos como os militares simbolizam suas missões na Amazônia em mitos e canções.

\section{A mística da Amazônia ${ }^{85}$}

A primeira análise materialista ${ }^{86}$ da guerra foi escrita por Tucídides. Seu relato desapaixonado e objetivo do confronto entre espartanos e

\footnotetext{
${ }^{85}$ A expressão mística da Amazônia é utilizada numa série de reportagens do Centro de Documentação do Exército sobre os significados dos brasões, canções e denominações históricas das organizações militares localizadas na Amazônia. O sentido atribuído à palavra mística nestas reportagens é o mesmo encontrado nos principais dicionários de língua portuguesa: "3. crença ou sentimento arraigado de devotamento a uma idéia, causa, clube, etc; 4. essência doutrinária" (Ferreira, 1999: 1346).

${ }^{86} \mathrm{O}$ termo materialista é adotado aqui tal qual é definido por Wendt. De acordo com o autor, na década de 1950 o debate teórico sobre política internacional estava centrado em categorias analíticas como poder e o interesse nacional. O poder era entendido como capacidade militar e o interesse nacional era conceituado como desejo de poder, segurança e riqueza. Esta maneira de interpretar o comportamento dos estados na arena internacional é costumeiramente identificada com o realismo. No começo da década de 1980, os teóricos liberais, sem desconsiderar a importância do poder e do interesse como chaves explicativas, começam a argumentar que as instituições internacionais também desempenham um papel importante na política internacional. Ainda que realistas e liberais
} 
atenienses rompeu uma longa tradição de narrativas mitológicas sobre as guerras gregas e introduziu uma nova forma de interpretá-las.

Em História da Guerra do Peloponeso, Tucídides afasta-se do registro mitológico para investigar quais foram as causas daquele que seria "o maior e mais valioso" 87 confronto travado pelos helenos. Longe "do reino das lendas" 88 , o historiador grego concluiu que o desejo por ganhos políticos, riquezas e glória, estava na raiz da desavença entre as cidadesestado. No século XIX, Sir George Grey fez o caminho inverso para apaziguar um conflito na polinésia. No "reino das lendas", ou, mais precisamente, nos mitos e poesias locais, o governador britânico obteve os conhecimentos necessários para compreender a lógica maori e encerrar a insurreição (Sahlins, 1990:78).

Durante décadas, a abordagem de Tucídides foi hegemônica no âmbito das relações internacionais. Os estados nacionais, assim como as cidades-estado gregas estudadas pelo pai da historiografia ocidental, competiriam e cooperariam na arena internacional de modo a acumular poder e preservar seus interesses. Suas burocracias nacionais (diplomatas e militares) seguiriam os mesmos desígnios. As questões culturais continuariam a ser vistas como fatos históricos entronizados no reino das lendas (Tucídides, 2004:12), que pouco agregariam à análise do comportamento estatal.

Mas o fim da Guerra Fria acabou por aproximar os teóricos das relações internacionais de Sir George Grey. A débâcle da União Soviética apontou empiricamente a limitação do argumento materialista: um modelo teórico focado apenas na análise dos fatores materiais é incapaz de

divirjam sobre o peso das variáveis, ambos concordam que a tríade poder, interesse e instituições é capaz de explicar a grande maioria das mudanças na ordem internacional. Embora nem realistas, nem liberais, auto-identifiquem-se como materialistas, ambos se referem às três variáveis já citadas, às instituições inclusive, como fatores materiais (Wendt, 2005:92). Por estes motivos, Wendt refere-se aos realistas e liberais como materialistas.

${ }^{87}$ Tucídides (2004:05).

${ }^{88}$ Tucídides (2004:12). 
interpretar situações como o colapso soviético (Katzenstein, 1996). Com o "retorno da cultura e da identidade na teoria das relações internacionais" (Kratochwill \& Lapid, 1997), a agenda de pesquisa sobre temas relacionados à segurança e defesa dinamizou-se. O diálogo com disciplinas especializadas nos estudos culturais como a sociologia e a antropologia, entre outras, ampliou o horizonte metodológico e teórico dos internacionalistas ${ }^{89}$, e lançou um novo olhar a respeito das burocracias estatais e das políticas públicas por elas implementadas.

A realização de estudos que levam em conta os aspectos culturais mostra que os mitos e poesias não são privilégios dos maori. As Forças Armadas, assim como as outras burocracias estatais ${ }^{90}$, também criam suas representações simbólicas. Esta seção procurará apreender o significado que os militares atribuem à sua missão na Amazônia através de alguns mitos e canções que foram criados pela instituição para representá-la.

\subsection{Pedro Teixeira: o Conquistador da Amazônia}

Na mitologia militar, o capitão-mor Pedro Teixeira teve um papel fundamental na expansão do domínio português sobre a Amazônia. Seu principal feito foi comandar uma expedição de exploração da calha do rio Amazonas que percorreu mais de $10.000 \mathrm{Km}$ de rios e trilhas. O objetivo desta missão no imaginário castrense era conhecer, explorar e expulsar contingentes estrangeiros que procuravam se fixar na calha do rio. Teixeira partiu de Cametá, no Pará, em outubro de 1637, e chegou a Quito em 1638. Quando retornava para o Pará, Pedro Teixeira colocou um marco no

\footnotetext{
${ }^{89}$ Os especialistas em relações internacionais.

90 "As organizações criam os mesmos sistemas coerentes de crenças que na ciência é chamado de conhecimento, na religião é chamado de moralidade e nas sociedades não ocidentais é chamado de mito (March; Sproull; Tamuz)". Os trabalhos de Dvora Yanow (1992) e (2000) utilizam este tipo de abordagem com bastante propriedade.
} 
trecho entre os rios Napo e Aguadilla, numa localidade que chamou de Franciscana. ${ }^{91}$ Nesta ocasião, ele teria proferido as seguintes palavras:

Tomo posse destas terras, pela Coroa de Portugal, em nome do Rei Felipe IV, nosso senhor, Rei de Portugal e Espanha; se houver entre os presentes alguém que contradiga ou que a embarge, que o escrivão da expedição o registre, pois, presentes por ordem da Real Audiência de Quito, encontram-se religiosos da Companhia de Jesus (Brasil 2003:11).

Estas palavras têm um grande valor simbólico para o Exército e são lidas nas cerimônias de entrega da medalha de serviço amazônico, que deve ser realizada, preferencialmente, no dia 16 de agosto, para relembrar o gesto do "Conquistador da Amazônia" (Brasil, 2003:11). Os feitos de Pedro Teixeira também são relembrados na Canção do soldado da Amazônia:

\section{(...) Nossa origem se prende às glórias}

Da bravura sem par das bandeiras,

Pois de Pedro Teixeira as vitórias

Demarcaram as nossas fronteiras

Estes feitos heróicos da história

E o povo ancestral denodado

Estão sempre presentes à memória

Nas ações de seu forte soldado (...). ${ }^{92}$

O trecho acima revela uma característica da identidade militar que já foi apontada anteriormente. Os militares brasileiros consideram-se os sucessores dos colonizadores portugueses. Por isso é recorrente nas canções militares a visão de que os fardados desempenham na Amazônia um papel semelhante ao que foi desempenhado pelos portugueses no período colonial.

\subsection{Os bandeirantes modernos}

\footnotetext{
${ }^{91}$ Carvalho (2000).

${ }^{92}$ Exército Brasileiro (2006g).
} 
Os engenheiros militares usam com freqüência recursos que os aproxima simbolicamente dos bandeirantes, a começar por uma peça de seu uniforme, o chapéu tropical, também chamado de "Chapéu Bandeirante".

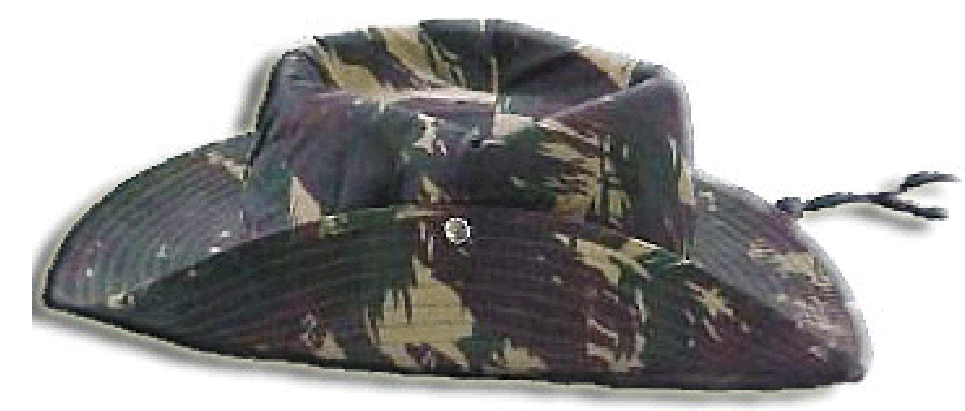

Figura 7 - Chapéu Bandeirante

Fonte: Exército Brasileiro (2006h)

O formato do chapéu tropical, com a aba direita pregada em sua copa é inspirado nos chapéus dos bandeirantes e foi adotado para simbolizar: "o desprendimento, o estoicismo e o desassombro pelo desconhecido" dos integrantes da arma de engenharia (Exército Brasileiro, 2006h). De fato o "espírito pioneiro" é uma das principais características dos oficiais da engenharia (Castro, 2004:82). Nas unidades baseadas na Amazônia este espírito se expressa na principal missão da arma na região: a construção de estradas. Os engenheiros crêem que "domando" a natureza e construindo estradas estarão contribuindo para a manutenção da soberania brasileira sobre a área. Esta crença está expressa na canção do $6^{\circ} \mathrm{BEC}$ intitulada $A$ mais bela batalha:

(...) Num contínuo rugir de motores.

Batalhão de novos pioneiros,

Seguidores do exemplo imortal

De engenheiros heróicos, guerreiros

Duma guerra como nunca houve igual. (estribilho)

Companhia de audazes, indômitos

Bandeirantes de raça viril,

Ansiosos por ver a Amazônia

Para sempre integrada ao Brasil (...). ${ }^{93}$

${ }^{93}$ Exército Brasileiro (2006i) 
$\mathrm{Na}$ batalha simbólica para manter a Amazônia integrada ao Brasil, os militares também recuperam outras imagens do período colonial como a Cruz de Cristo. Este símbolo está associado à expansão do Império português e ornava as caravelas que chegaram à América no século XVI.

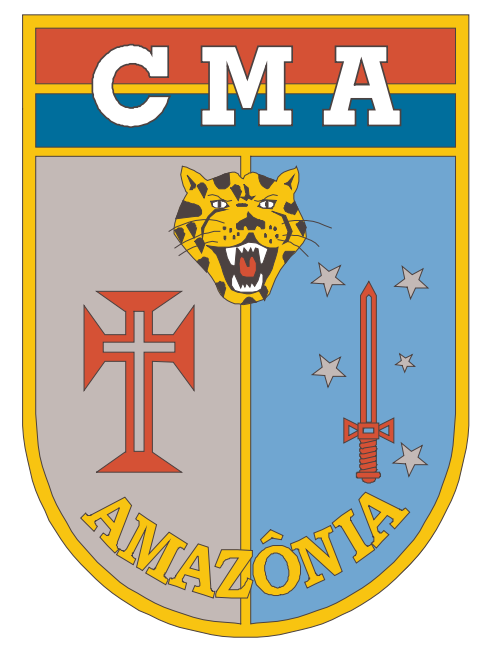

Figura 8 - Distintivo do Comando Militar da Amazônia Fonte: Exército Brasileiro (2006j)

No distintivo do Comando Militar da Amazônia ${ }^{94}$, a Cruz de Cristo aparece ao lado de um sabre que representa o Comando do Exército, ilustrando, desta forma, a continuidade imaginada entre a conquista da Amazônia pelos portugueses e o esforço do Exército para mantê-la integrada ao território nacional.

Ainda no terreno da simbologia, é bastante significativo que a $12^{\mathrm{a}}$ Região Militar, responsável pela defesa da Amazônia Ocidental, e quatro das cinco Brigadas de Infantaria localizadas na área, tenham recebido denominações históricas que homenageiam personagens do período colonial, como já foi exposto na seção anterior.

Mas não é somente a tradição que equipara colonizadores e militares, inventada pelo Exército, que está representada no distintivo do Comando Militar da Amazônia. O "ponto-de-honra" do distintivo é ocupado

${ }^{94}$ O distintivo do Comando Militar da Amazônia foi modificado em 1997 para incorporar as tradições inventadas pelo Exército na última década. 
por uma cabeça de onça pintada, um símbolo "genuinamente nacional" que representa a selva amazônica e o "indômito sentimento de brasilidade em sempre guardá-la e defendê-la (Exército Brasileiro, 2006j)".

\subsection{Os guerreiros de selva e o espírito de Guararapes}

A onça pintada é um símbolo bastante utilizado pelas unidades militares localizadas na Amazônia. Ela também ilustra o distintivo do Centro de Instrução de Guerra na Selva (CIGS), sediado em Manaus, onde são formados os especialistas em guerra na selva, também conhecidos como guerreiros de selva ${ }^{95}$. Esses militares são muito prestigiados no Exército, desde que a Amazônia se tornou a prioridade estratégica das Forças Armadas. O CIGS justifica a escolha da onça pintada como animal-símbolo do guerreiro de selva ressaltando algumas características do animal tais como, ferocidade, tenacidade, paciência, agilidade e sagacidade, que são exigidas dos militares que pretendem se especializar nesse tipo de guerra (Exército Brasileiro, 2007i).

A Oração do Guerreiro de Selva, composta em 1981 pelo então $1^{\circ}$ tenente Humberto Batista Leal, representa da seguinte forma a missão das tropas selváticas:

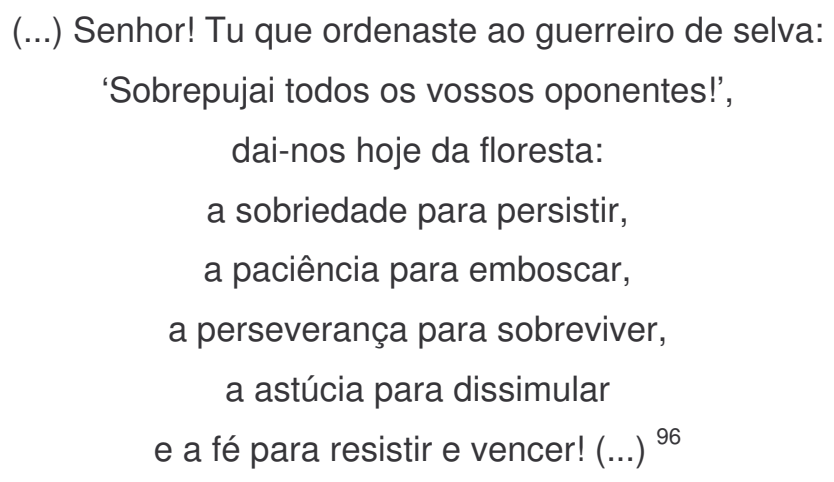

\footnotetext{
${ }^{95}$ O Centro de Instrução de Guerra na Selva foi criado em 1966 e desde então vem sendo um importante produtor de doutrinas e representações simbólicas sobre a Amazônia. A canção do CIGS e o poema intitulado "Sentinela amazônida" são dois produtos simbólicos do centro de instrução.

${ }^{96}$ Exército Brasileiro (2006I).
} 
Essa oração que inicialmente era recitada apenas no Centro de Instrução de Guerra na Selva, hoje é declamada em todas as organizações do Comando Militar da Amazônia. Nas cerimônias militares sua declamação é precedida e concluída com os acordes musicais da ópera de Carlos Gomes O Guarani e da música Aquarela do Brasil de Ary Barroso, entoados por bandas de música. A difusão da Oração do Guerreiro de Selva provavelmente ganhou força depois que o Exército passou a considerar, entre as suas estratégias militares, a guerra de resistência. Dentro dessa estratégia, "as tropas selváticas", como são conhecidas, desempenham um papel fundamental. Logo suas representações simbólicas ganharam força na instituição.

A estratégia da resistência, como já foi dito anteriormente, tem como uma de suas principais fontes de inspiração a Insurreição Pernambucana. A força simbólica desse evento é tamanha que o Exército brasileiro escolheu 019 de abril, data da $1^{\text {a }}$ Batalha de Guararapes (1648), para comemorar o dia do Exército ${ }^{97}$.

Celso Castro, em seu livro "A invenção do Exército brasileiro", afirma que a perda de poder político das Forças Armadas brasileiras após o fim da ditadura militar operou modificações importantes nos elementos simbólicos que caracterizaram a instituição por décadas. Comemorações que foram importantes na época da ditadura, como a vitória sobre a Intentona Comunista $^{98}$ e a lembrança da "Revolução" de 31 de março de $1964^{99}$, entraram em declínio ao passo que novas comemorações, como o dia do Exército, foram criadas (Castro, 2002:68). O autor argumenta que é possível associar a crescente importância simbólica da Batalha de

\footnotetext{
${ }^{97} \mathrm{O}$ dia do Exército foi criado em 24 de março de 1994 por decreto presidencial. O então ministro do Exército, general Zenildo Lucena, empenhou-se pessoalmente na criação desta comemoração e também na construção de centros culturais, monumentos e memoriais do Exército (Freitas, 1998:48).

${ }^{98}$ Ficou conhecida como "Intentona" a série de revoltas comunistas, protagonizada principalmente por militares, que ocorreram em Natal, Recife e no Rio de Janeiro em novembro de 1935.

${ }^{99}$ Os militares brasileiros chamam o golpe de 1964 de revolução.
} 
Guararapes para o Exército brasileiro à percepção institucional de que a Amazônia é alvo da cobiça internacional e deve ser defendida.

Neste sentido, Guararapes ganha força no imaginário militar à medida que se consolida na instituição a idéia de que a única forma de combater um inimigo possuidor de um poder militar incontestavelmente superior na Amazônia é utilizar os mesmos métodos e lutar com o mesmo espírito que animou as tropas luso-brasileiras que venceram os holandeses em Pernambuco.

Em suma, para justificar as opções estratégicas feitas no final século $\mathrm{XX}$, os militares inventam uma tradição de continuidade com um passado mítico e valorizam determinadas representações simbólicas em detrimento de outras.

No próximo capítulo examinaremos as percepções da Força Aérea e da Marinha sobre os problemas de Defesa Nacional na Amazônia e as conseqüências organizacionais da prioridade estratégica da região para as duas Forças. 


\section{CAPÍTULO IV}

\section{A FORÇA AÉREA E A MARINHA NA AMAZÔNIA: FORÇAS COADJUVANTES DA PRESENÇA ESTATAL}

Oliveiros Ferreira lamenta que, desde o advento da República, a Marinha, e, posteriormente, a Força Aérea tenham desempenhando um papel secundário na estratégia militar brasileira (Ferreira, 1988). A Amazônia alçada à principal vulnerabilidade estratégica do país perpetua, de certa forma, o arranjo criticado por Ferreira, pois como a área é considerada um teatro de operações terrestre, o Exército, mais uma vez, assume um papel proeminente na estratégia de defesa da região. Este capítulo analisará como a Força Aérea e a Marinha estão se adaptando a este cenário estratégico.

\section{As duas faces da Aeronáutica no Brasil}

Para compreender melhor o papel desempenhado pela Força Aérea Brasileira na Amazônia é preciso esclarecer algumas peculiaridades da Aeronáutica no Brasil. Uma pequena estória do anedotário militar expõe uma dessas peculiaridades. Na década de 1950, um aluno da ECEMAR ${ }^{100}$ intrigado com o organograma exposto pelo instrutor, durante uma aula sobre o funcionamento da nova Força, perguntou-Ihe qual seria o lugar da

${ }^{100}$ O Curso de Estado-Maior da Aeronáutica foi criado em 1946. 
FAB na estrutura da Aeronáutica. Após debaterem o assunto, e sem chegar a um consenso, o Coronel questionado vaticinou:

— Major, a Força é conceitual e não estrutural (Souza Júnior, 2004:08).

Cinco décadas depois do folclórico diálogo entre os dois militares, a FAB continua sendo conceitual, ou seja, ela não consta na apresentação da estrutura do Comando da Aeronáutica (COMAER) disponível no sítio oficial da Força ${ }^{101}$. No organograma da Aeronáutica o Comando Geral de Operações Aéreas (COMGAR) ${ }^{102}$, que é o braço armado do COMAER, divide espaço com outros três comandos gerais: o Comando-Geral de Apoio (COMGAP) ${ }^{103}$, o Comando-Geral do Pessoal (COMGEP) ${ }^{104}$, o Comando-Geral de Tecnologia Aeroespacial (CTA ${ }^{105}$, dois departamentos: - Departamento de Controle do Espaço Aéreo (DECEA) ${ }^{106}$ e o Departamento de Ensino da Aeronáutica (DEPENS) ${ }^{107}$, e um Conselho: o

${ }^{101} \mathrm{O}$ organograma da FAB pode ser consultado em: Força Aérea Brasileira (2007a).

102 O COMGAR é o responsável pelas atividades operacionais da Aeronáutica. Ao órgão compete o comando, o planejamento, a direção, a fiscalização, a coordenação, a execução e a avaliação do emprego de todas as unidades da FAB (Força Aérea Brasileira, 2006a). ${ }^{103}$ O COMGAP é o grande comando logístico de meios materiais e serviços que permite o funcionamento das diferentes organizações do COMAER (Força Aérea Brasileira, 2006b). 104 O COMGEP é o órgão responsável pela política de pessoal do Comando da Aeronáutica (Força Aérea Brasileira, 2006c).

105 O CTA, antigo Centro Técnico Aeroespacial, responde pela consecução dos objetivos da Política Aeroespacial Nacional para os setores da Ciência, Tecnologia e Indústria e contribui para a formação e condução da Política Nacional de Desenvolvimento das Atividades Espaciais (Força Aérea Brasileira, 2006d).

106 Ao DECEA compete o planejamento, regulamentação, cumprimento de acordos, normas e regras internacionais relativas à atividade de controle do espaço aéreo brasileiro. O órgão também se responsabiliza pela operação, atualização e manutenção de toda a infra-estrutura de meios necessários à comunicação e navegação aérea, nacional e internacional, que circula no espaço aéreo brasileiro (Força Aérea Brasileira, 2006e).

107 O DEPENS administra e coordena as atividades de todas as escolas da Força Aérea Brasileira, com exceção do ITA, o Instituto Tecnológico de Aeronáutica (Força Aérea Brasileira, 2006f). 
Conselho Superior de Economia e Finanças da Aeronáutica (CONFESA) $)^{108}$. A Agência Nacional de Aviação (ANAC) ${ }^{109}$, que substituiu o Departamento de Aviação Civil (DAC), não se subordina mais ao COMAER, mas permanece vinculada ao Ministério da Defesa.

Contudo não é somente o caráter "conceitual" da FAB que persiste na organização da Aeronáutica. Desde que se tornou uma Força Militar independente, em 1941, além de incorporar o acervo da aviação naval e militar (pertencente ao Exército), a instituição também assumiu o controle do Departamento de Aviação Civil (DAC), à época subordinado ao Ministério da Viação e Obras Públicas (Aeronáutica, 1998:48). Quando o Marechal Casimiro Montenegro voltou de uma viagem de trabalho aos Estados Unidos, encantado com o que vira no Massachusetts Institute of Technology (MIT) e decidido a criar uma estrutura similar no Brasil, o Ministério da Aeronáutica encampou o projeto (Morais, 2006:101-121). Como resultado, o ITA está subordinado ao COMAER até hoje. Na década de 1970, por ocasião da implantação do CINDACTA, o COMAER tomou para si o comando da rede de radares e centros de controle responsáveis tanto pelas operações civis quanto pelas operações militares. ${ }^{110}$ Enfim, a multiplicidade de funções civis e militares exercidas pela Aeronáutica

108 O CONFESA é o órgão da Aeronáutica que superintende as atividades de administração financeira, contabilidade e auditoria da instituição (Força Aérea Brasileira, 2006g).

${ }^{109}$ A ANAC foi implantada em 20 de março de 2006 e assumiu as responsabilidades anteriormente atribuídas ao DAC, a saber, o planejamento, gerenciamento e controle das atividades relacionadas com a aviação civil (Agência Nacional de Aviação Civil, 2007).

${ }^{110}$ Os Centros Integrados de Defesa Aérea e Controle do Tráfego Aéreo (CINDACTA) têm como missão exercer a vigilância e o controle da circulação aérea geral, assim como vetorar as aeronaves responsáveis pela manutenção da integridade e soberania do espaço aéreo brasileiro na área de sua competência (CINDACTA III, 2007). O CINDACTA I foi instalado em 1973 no Distrito Federal, e cobre as rotas mais congestionadas do país na região sudeste e parte da região centro-oeste. O CINDACTA II, sediado em Curitiba, foi ativado em 1985 e é responsável pelas rotas da região sul do país. O CINDACTA III, com sede em Recife, foi ativado em 1988 e responde pelo tráfego aéreo da região nordeste. Já o CINDACTA IV foi ativado somente em 2006, na cidade de Manaus, após o fim da instalação do SIVAM. 
abrange, além da área que the é concernente, ou seja, a aviação militar, o gerenciamento do tráfego aéreo da aviação civil, e de um ramo importante da pesquisa científica no país: a área aeroespacial. Isto influencia sobremaneira o perfil organizacional e doutrinário da Força.

No que diz respeito à presença militar na Amazônia, veremos que as ações cívico-sociais e missões relacionadas ao desenvolvimento regional deram a tônica da atuação da Aeronáutica na área até a década de 1980. Com a criação do Programa Calha Norte e, mais recentemente, com a implantação do Projeto SIVAM e a promulgação da lei do tiro de destruição, o foco da atuação da FAB na região amazônica vem mudando paulatinamente.

\section{A presença da Força Aérea na Amazônia: um breve histórico}

A construção das primeiras unidades da Força Aérea na Amazônia foi impulsionada pela expansão das rotas do Correio Aéreo Militar (CAM), o precursor do Correio Aéreo Nacional (CAN), na década de 1930 111 . Em agosto de 1931, o então Capitão Aviador Lysias Rodrigues partiu por terra do Campo dos Afonsos, no Rio de Janeiro, rumo a Belém. Ele estava acompanhado por dois funcionários da companhia aérea Pan American, interessados em encontrar uma rota mais econômica entre o Rio de Janeiro e Miami. A viagem durou 52 dias e, durante o seu trajeto, o capitão Lysias demarcou cerca de 17 novos campos de pouso. Quatro anos mais tarde, foi inaugurada a primeira rota do CAM para a região amazônica $(\mathrm{LORCH}$, 2000:61-62). Em 1936, um ano após a chegada do CAM à Amazônia, foi criado o $1^{\circ}$ Regimento de Aviação, no Pará, e em 1944, nos terrenos de Val-de-Cães, foi criada a Base Aérea de Belém (Carvalho, 2000:50).

${ }^{111}$ O Correio Aéreo Militar, operado pelo Grupo Misto de Aviação do Exército, foi criado em 1931 com o vôo inaugural dos tenentes Casimiro Montenegro e Nelson LavanèreWanderley do Rio de Janeiro para São Paulo. Em 1941, com a criação do Ministério da Aeronáutica, o Correio Aéreo Militar foi fundido com o Correio Aéreo Naval e rebatizado de Correio Aéreo Nacional (Lorch, 2000:57). 
As memórias e monografias da ECEMAR escritas por aviadores que estiveram na Amazônia entre as décadas de 1950 e 1980 revelam que a ação da FAB na região durante este período esteve prioritariamente voltada para o cumprimento de missões ligadas ao desenvolvimento da área e ao desejo de integrá-la ao restante do país.

Sobre o espírito "desenvolvimentista" da Aeronáutica cabe lembrar que a geração de oficiais responsáveis pela criação da Força, na década de 1940, era fortemente influenciada pelo ideário tenentista e via na aviação mais do que uma arma militar. De acordo com a percepção vigente na caserna aquela época, as Forças Armadas, em tempos de paz, deveriam desempenhar atividades que concorressem para desenvolvimento do país e a aviação, dentro desta perspectiva, parecia aos militares de então um poderoso instrumento de integração nacional.

O frisson causado pela chegada do Correio Aéreo ao interior do Brasil rendeu aos aviadores militares o cognome de "bandeirantes dos ares" (Morais, 2006: 44). O hino Bandeirante do Ar composto pelo cadete Luiz Felipe de Magalhães remete a este imaginário:

(...) Não tememos da luta os perigos

Nem dos céus a infinita amplidão

Sobre mares, planícies, sobre montes

Viveremos por sempre a voar

Bandeirantes de novos horizontes

Para a bandeira da Pátria elevar

Bandeirantes de novos horizontes

Para a suprema conquista do ar $(\ldots)^{112}$

A figura do bandeirante, como já vimos no terceiro capítulo, é bastante recorrente no imaginário militar sobre a Amazônia. No caso específico dos oficiais da FAB, a percepção de que são eles os legítimos sucessores dos desbravadores coloniais é reforçada pelo ineditismo do transporte aéreo, aliada ao parco conhecimento da região pelas agências estatais. Isso aguçava o espírito dos aviadores, como pode ser constatado nas passagens abaixo:

\footnotetext{
${ }^{112}$ Magalhães (2005).
} 
A viagem continua. Desfila, abaixo das asas metálicas do nosso Douglas $^{113}$, a natureza com todo o seu esplendor. Muitos rios, matas intermináveis, manifestações de intensa vida. Para mim foi outro dia pleno de novidades. Sentia-me como os bandeirantes e desbravadores pioneiros que, no passado distante, à medida que avançavam para 0 desconhecido, a cada passo, novas surpresas e atrações (Silveira, 1987:18).

A FAB, ao chegar à Amazônia, em 1935, viu uma região intacta e virgem como Cabral a encontrou durante o descobrimento do Brasil. Começou, desde então, uma aventura com os aviões Waco e, posteriormente, continuou com os Catalinas em busca de novos horizontes (Guimarães, 1980:18).

A criação da Comissão de Aeroportos da Amazônia (COMARA), em 1953, é um passo importante do esforço "desenvolvimentista" da Aeronáutica na região norte. Na década de 1950 existiam apenas 17 aeródromos na Amazônia, sendo que somente dois deles (o de Manaus e o de Belém) eram asfaltados. A COMARA, implantada no âmbito da Superintendência do Plano de Valorização Econômica da Amazônia $(\text { SPVEA })^{114}$, tinha entre as suas atribuições a implantação da malha aeroviária da região ${ }^{115}$.

Mas é importante lembrar que a COMARA também cumpria uma função de natureza militar. A revolta de Jacareacanga ${ }^{116}$, em 1956, chamou

\footnotetext{
${ }^{113}$ Aeronave utilizada pela $\mathrm{FAB}$ na década de 1960 para o transporte de passageiros e cargas na região amazônica.

114 A SPVEA é antecessora da Superintendência de Desenvolvimento da Amazônia (SUDAM).

${ }^{115}$ Além de suas atribuições originárias, a COMARA atua no apoio às organizações do Exército e da Marinha presentes na região através da construção e manutenção de pistas de pousos nessas unidades (COMARA, 2006).

${ }^{116}$ Em 10 de fevereiro de 1956, um grupo de oficiais da Aeronáutica insatisfeitos com a posse de Juscelino Kubitschek partiu do Campo dos Afonsos e se instalou na Base Aérea de Jacareacanga, no sul do Pará. Pouco tempo depois, os aviadores controlavam as localidades de Cachimbo, Belterra, Itaituba, Aragarças e Santarém. Os rebelados, que não aceitavam a vitória de Kubitschek nas urnas, temiam represálias do grupo de militares que garantiu a posse do presidente eleito e exigiam a saída do ministro da Aeronáutica, Vasco Alves Seco. Após 19 dias, o governo federal conseguiu debelar a revolta.
} 
a atenção do Comando da Aeronáutica para as dificuldades logísticas na Amazônia. A inexistência de aeroportos obrigava os aviões da FAB a pousar nos rios e este era um dos fatores que tornavam a região vulnerável estrategicamente.

Em verdade, se atentarmos para a concepção de segurança nacional ${ }^{117}$ da geração de militares que criaram a Aeronáutica, nós veremos que mesmo atividades voltadas para o desenvolvimento econômico, como a construção da infra-estrutura aeroportuária, eram vistas pelos oficiais da FAB como ações necessárias para garantir a segurança militar da Amazônia.

As atividades cívico-sociais da Aeronáutica também eram encaradas como missões militares por seus oficiais. A FAB desenvolveu, por meio da COMARA, um método de ação segundo o qual caberia à Força apoiar o trabalho das ordens religiosas e da FUNAI junto às comunidades indígenas que habitavam os lindes da Amazônia. Esta é a gênese dos trinômios $\mathrm{FAB} /$ missionários/índios e FAB/FUNAl/índios.

Estes trinômios eram vistos pela Aeronáutica como "o mais eficiente veículo da constante e discreta vigilância" das fronteiras oeste e norte do país (Pliopas, 1975:28). Na percepção da Força, o índio, uma vez aculturado, "transforma-se em eficientíssima sentinela das fronteiras, nos pontos onde o Exército ainda não tem meios para atuar (Pliopas, 1975:28)". Por isso, a FAB, durante décadas, teve como uma de suas principais missões na Amazônia o apoio às missões religiosas que se estabeleceram nas regiões fronteiriças.

As missões religiosas católicas eram tidas pela $F A B$ como "nacionais" e, por suposto, "confiáveis" ${ }^{118}$. Nos lindes da Amazônia elas

\footnotetext{
117 Sobre as linhas gerais da doutrina de segurança nacional brasileira ver: Alves, (1984), Comblin (1978) e Oliveira (1987).

118 O espírito "cívico" das missões católicas costuma ser exaltada pelos oficiais da FAB que servem na Amazônia: "Para cumprir essa missão, era preciso sinceridade, espírito de sacrifício, ardor cívico e consciência isenta de qualquer segunda intenção. Só o missionário possui o espírito de sacrifício que lhe dá a santidade de mártir (Assis, 1982:11)".
} 
representavam um contraponto às missões protestantes e evangélicas, vistas como "desnacionalizantes" e "suspeitas", como já foi exposto no segundo capítulo. A presença dos religiosos católicos na fronteira norte, dentro desta lógica, servia para "impedir a evasão dos índios do território brasileiro para os países limítrofes" onde religiosos protestantes, contando com recursos financeiros vultuosos, ofereciam assistência médica e educacional aos nativos ${ }^{119}$.

A atribuição de um significado militar a atividades de outra natureza, levou a Aeronáutica a modificar a destinação de aeronaves e armamentos para atuar na Amazônia ${ }^{120}$. Os PV-1, A-28 e os Catalina, aeronaves de patrulha doadas ao Brasil pelos Estados Unidos após o fim da Segunda Guerra Mundial, foram convertidas para o transporte de passageiros e cargas (Souza Júnior, 2004:36). O Napalm, um armamento que as tropas norte-americanas utilizaram nos conflitos do sudeste asiático, serviu, aqui no Brasil, com exceção do episódio do Araguaia $^{121}$, para facilitar o acesso

\footnotetext{
${ }^{119}$ A infra-estrutura das missões protestantes estrangeiras na Amazônia, algumas das quais possuíam aviação própria num período em que a Aeronáutica brasileira carecia de aeronaves para apoiar as missões católicas, era vista com um misto de desconfiança e inveja pelos aviadores militares brasileiros.

${ }^{120}$ A atribuição de novas funções a aeronaves e armamentos no Brasil revela uma das limitações das abordagens materialistas para interpretar o significado da posse de artefatos militares pelas Forças Armadas nacionais. De fato a capacidade dos países industrializados influenciarem a construção das doutrinas militares dos demais países através da cessão de equipamentos é relativa, uma vez que este gesto político é invariavelmente mediado pelo contexto político nacional, ou nas palavras de Elizabeth Kier, pelo balanço de poder doméstico, e pela cultura organizacional das Forças Armadas que recebem os equipamentos. No caso da conversão das aeronaves de patrulha em aeronaves de transporte a serviço do Correio Aéreo Nacional, pesaram muito as idéias do Brigadeiro Eduardo Gomes, que além de ser militar de carreira era uma importante liderança política na época, acerca das missões prioritárias Aeronáutica. Para uma discussão pormenorizada dos diferentes significados que a posse de artefatos militares podem ter para as Forças Armadas ver: Eyre; Suchman (1996) e Price; Tannenwald (1996).

${ }^{121}$ O Napalm foi utilizado pela $F A B$, sem sucesso, para tentar localizar guerrilheiros na região do Araguaia. Mais informações a este respeito ver: Studart (2006).
} 
dos pára-quedistas que saltavam para abrir clareiras que precediam a construção de pistas de pouso na floresta (Carvalho, 20-21).

A instituição do Calha Norte, em meados da década de 1980, trouxe uma nova dimensão à presença e atuação da Aeronáutica na Amazônia. As solicitações da aviação de transporte aumentaram sensivelmente em razão da implantação do Projeto, somando-se à missão, já tradicional, da FAB de prestar apoio às unidades militares localizadas na região, lembrando que o Exército e, em menor escala, a Marinha, dadas as características fisiográficas da região, dependem substancialmente do apoio logístico da Força Aérea para seu preparo e emprego (Costa, 1989). O incremento da preocupação com a segurança militar da área também colocou em evidência a falta de experiência da FAB no emprego combinado com as demais Forças Singulares (Trompowsky, 1990:1-4). O perfil organizacional da Aeronáutica na região norte nos ajuda a compreender com mais propriedade algumas das mudanças engendradas na dinâmica interna da FAB devido a prioridade estratégica atribuída à Amazônia nas últimas décadas.

\subsection{Estrutura organizacional da Força Aérea na Amazônia}

A Força Aérea Brasileira está organizada em sete Comandos Aéreos Regionais (COMAR). O I COMAR sediado em Belém, o II COMAR com sede em Recife, o III COMAR localizado no Rio de Janeiro, o IV COMAR sediado em São Paulo, o V COMAR com sede em Canoas-RS, o VI COMAR localizado em Brasília e o VII COMAR sediado em Manaus. 


\section{COMANDOS AÉREOS REGIONAIS}

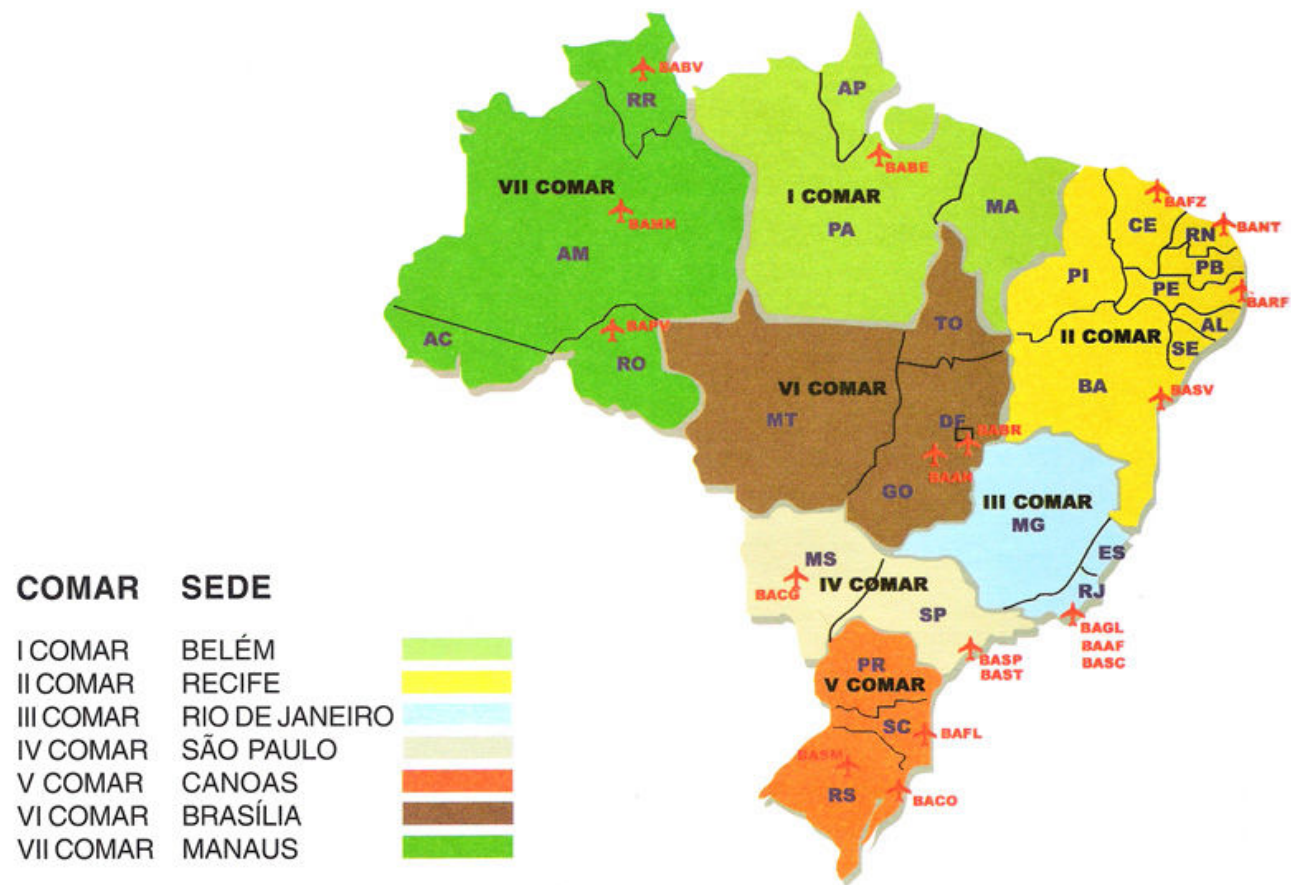

Figura 9 - Comandos Aéreos Regionais

Fonte: Instituto Histórico-Cultural da Aeronáutica

O I COMAR tem jurisdição sobre os estados do Pará, Maranhão e Amapá, sob sua direção estão a Base Aérea de Belém (BABE), a Prefeitura de Aeronáutica de Belém (PABE) $)^{122}$ e o $1^{\circ}$ Esquadrão de Transporte Aéreo ( $1^{\circ}$ ETA). Criada em 1944, a BABE é uma unidade administrativa que abriga três unidades aéreas operacionais: $01^{\circ}$ Esquadrão do $8^{\circ}$ Grupo de Aviação ( $\left.1 \% 8^{\circ} \mathrm{GAV}\right)$, denominado Esquadrão Falcão, o $3^{\circ}$ Esquadrão do $7^{\circ}$ Grupo de Aviação $\left(3^{\circ} / 7^{\circ} \mathrm{GAV}\right)$, que é chamado de Esquadrão Netuno, e o $1^{\circ} \mathrm{ETA}$, conhecido como Esquadrão Tracajá.

O Esquadrão Falcão foi criado em 1972 e é formado por helicópteros que cumprem missões de infiltração e exfiltração de tropas, busca e salvamento em combate, tanto na selva como no mar. $\mathrm{O} 1^{\circ} / 8^{\circ} \mathrm{GAV}$ também realiza missões de apoio social e humanitário junto às populações

${ }^{122}$ A Prefeitura de Aeronáutica é a organização do Comando da Aeronáutica destinada a administrar, em uma determinada área, os bens móveis e imóveis de natureza comum, pertencentes à União e jurisdicionados ao Comando da Aeronáutica (Brasil, 1974). 
ribeirinhas e indígenas. O Falcão está subordinado à II Força Aérea (II FAE) ${ }^{123}$ (Força Aérea Brasileira, 2005a).

O Esquadrão Netuno ${ }^{124}$ é originário da Primeira Flotilha de Bombardeio e Patrulha, pertencente à Aviação Naval. Em 1942, o Netuno passou a operar sob o comando da Aeronáutica. O $3^{\circ} / 7^{\circ}$ GAV é formado por aviões que cumprem missões de esclarecimento e patrulha marítima e também está subordinado à II FAE (Força Aérea Brasileira, 2005b).

Os Esquadrões de Transporte Aéreo foram criados em 1969 para descentralizar as operações do Comando de Transporte Aéreo (COMTA), já extinto, e realizar missões de transporte aeroterrestre, logístico, lançamentos de cargas, evacuação aeromédica, humanitárias, de socorro a vítimas em casos de desastres naturais e cooperação com o Exército e a Marinha. O Esquadrão Tracajá125, como já foi dito, está subordinado diretamente ao I COMAR (Força Aérea Brasileira, 2005c).

A maioria dos esquadrões da FAB que cumpre missões de vigilância e patrulhamento das fronteiras está sob a jurisdição do VII COMAR, o órgão responsável pela defesa do espaço aéreo da Amazônia Ocidental ${ }^{126}$.

${ }^{123}$ A II FAE, sediada no Rio de Janeiro, reúne as unidades de asas rotativas (helicópteros), as unidades de busca e salvamento, as unidades de patrulha marítima e de apoio a Marinha em geral. Ela emprega aeronaves em operações aerotáticas independentes ou com as Forças Navais (Força Aérea Brasileira, 2006a).

${ }^{124} \mathrm{O}$ nome do esquadrão inspira-se no deus romano Netuno que na mitologia é o soberano de todos os mares. Também na mitologia romana, Netuno é filho de Saturno, o protetor dos navegantes. Esses elementos mitológicos remetem à missão de guardião dos mares do norte do país desempenhada pelo $3^{\circ} / 7^{\circ}$ GAV (Força Aérea Brasileira, 2005b).

${ }^{125}$ O tracajá é uma tartaruga típica da região amazônica. No brasão do $1^{\circ}$ ETA, ela aparece alada, remetendo à lentidão dos legendários aviões Catalina que apoiaram as unidades militares na fronteira amazônica do Pós-Guerra até a década de 1980. Os Catalina costumavam demorar bastante para chegar ao seu destino, mas sempre cumpriam suas missões. O lema do esquadrão é "devagar, mas chego lá" (Força Aérea Brasileira, 2005c).

${ }^{126}$ A canção do VII COMAR reflete a identidade do órgão, cada vez mais comprometido com a proteção dos recursos naturais existentes na Amazônia:

"Imenso verde com águas e riquezas,

O desafio das longínquas fronteiras. 
Estas missões se intensificaram a partir da ativação do SIVAM e, especialmente, após a promulgação da Lei do Tiro de Destruição, que ficou conhecida como Lei do Abate.

\subsubsection{A Lei do Tiro de Destruição, os Atos Internacionais e as Operações Aéreas Bilaterais}

Pode-se afirmar que a regulamentação da Lei do Tiro de Destruição tem uma relação direta com a ativação do SIVAM. Com a modernização do sistema de defesa aérea e controle do tráfego aéreo, comprovou-se que os ilícitos entram em território brasileiro principalmente por via aérea. Comprovou-se também que esses ilícitos são transportados em pequenas aeronaves provenientes de nossos vizinhos amazônicos.

Com um sistema de detecção mais apurado, cresceram os casos em que as aeronaves de interceptação da FAB tiveram suas ordens (de identificação e de pouso em pista pré-determinada) ignoradas por pilotos que realizavam vôos clandestinos sobre a região amazônica, e a pressão para que o Brasil colocasse em prática uma legislação semelhante a que foi adotada por países vizinhos, como a Colômbia e o Peru, que permite a destruição de aeronaves consideradas hostis.

A Lei no 9.614, de 05 de março de 1998, entrou em vigor em 14 de outubro de 2004 através do Decreto n 5.144, de 16 de julho de 2004. Esta lei dispõe sobre o Código Brasileiro de Aeronáutica, instituído pela Lei no 9.614, de 19 de dezembro de 1986, modificando-o com a inclusão de um parágrafo que trata da destruição de aeronaves classificadas como hostis:

$\S 20$ Esgotados os meios coercitivos legalmente previstos, a aeronave será classificada como hostil, ficando sujeita à medida de destruição, nos casos dos incisos do caput deste artigo e após autorização do Presidente da República ou autoridade por ele delegada (Brasil, 1998).

No teu exemplo de coragem e presteza,

És pássaro defendendo a natureza (Silva, 2006)". 
Só estarão sujeitas à medida de destruição, as aeronaves que, sendo consideradas suspeitas e submetidas a procedimentos específicos de abordagem, ignorarem as ordens das aeronaves de interceptação da FAB. De acordo com a legislação brasileira é considerada suspeita a aeronave que:

1. Entrar em território nacional, sem plano de vôo aprovado, oriunda de regiões reconhecidamente fontes de produção ou distribuição de drogas ilícitas; ou

2. Omitir aos órgãos de controle de tráfego aéreo informações necessárias à sua identificação, ou não cumprir determinações dessas mesmas autoridades, caso esteja trafegando em rota presumivelmente utilizada na distribuição de drogas ilícitas.

Uma vez considerada suspeita, a aeronave está sujeita a oito procedimentos coercitivos, aplicados de forma progressiva e sempre que o procedimento anterior não obtiver êxito: (1) reconhecimento à distância; (2) confirmação de matrícula; (3) interrogação na freqüência prevista para a área; (4) interrogação na freqüência internacional de emergência; (5) realização de sinais visuais; (6) mudança de rota; (7) pouso obrigatório; (8) tiro de advertência; com munição traçante, lateralmente à aeronave suspeita, de forma visível e sem atingi-la. Caso a aeronave não responda a nenhum dos procedimentos coercitivos citados, ela será considerada hostil e está sujeita à medida de destruição que consiste na realização de disparo de tiros, feitos pela aeronave de interceptação, com a finalidade de provocar danos e impedir o prosseguimento do vôo da aeronave transgressora (Força Aérea Brasileira, 2007b).

O Decreto no 5.144 delega ao Comandante da Aeronáutica a responsabilidade de autorizar o tiro de destruição. Deixando claro que esta medida só ocorrerá quando forem cumpridos os seguintes procedimentos: (1) todos os meios envolvidos devem estar sob o controle operacional do Comando de Defesa Aeroespacial Brasileiro (COMDABRA) ${ }^{127}$; (2) as

${ }^{127}$ O COMDABRA foi ativado em 1995 para coordenar as atividades do Sistema de Defesa Aeroespacial Brasileiro (SISDABRA), que é constituído pelas unidades militares que 
medidas coercitivas citadas anteriormente devem ser registradas em gravação sonora e/ou visual das comunicações; (3) o tiro de destruição será executado apenas por pilotos e controladores de defesa aérea qualificados segundo os padrões estabelecidos pelo COMDABRA; (4) o procedimento ocorrerá sobre áreas não densamente povoadas e relacionadas com rotas presumivelmente utilizadas para o tráfico de drogas (Força Aérea Brasileira, 2007b).

A promulgação da Lei do Tiro de Destruição ${ }^{128}$ foi precedida por conversações sobre medidas de integração de procedimentos de interdição de aeronaves hostis com os países vizinhos. Como parte deste processo de aproximação, foram assinados vários acordos e memorandos de entendimento bilaterais com países fronteiriços que também enfrentam problemas relacionados aos ilícitos transnacionais.

O processo de aproximação diplomática do Brasil com os vizinhos do Pacto Amazônico nas áreas de segurança e defesa vem avançando de forma paulatina desde a última década. Com o Peru, o Brasil assinou um Memorando de Entendimento sobre Cooperação em Matéria de Proteção e Vigilância da Amazônia. Celebrado em 25 de agosto de 2003, na cidade de Lima, no Peru, e promulgado pelo Decreto nํ⒌752 de 12 de abril de 2006 .

podem ser utilizadas para assegurar o exercício da soberania no Espaço Aéreo Brasileiro. Estão sob o comando do SISDABRA, os Grupos de Artilharia Anti-Aérea do Exército e da FAB, os CINDACTA e o $2^{\circ} / 6^{\circ} \mathrm{GAv}$. Cabe ao COMDABRA propor a política, a estratégia e a doutrina para o funcionamento do SISDABRA; estabelecer os princípios, fixar os critérios, elaborar normas e programas que assegurem a perfeita integração e o desempenho eficiente do SISDABRA; supervisionar o controle de toda a circulação aérea, geral e operacional militar, no Espaço Aéreo Brasileiro; coordenar as unidades do SISDABRA, as ações relacionadas com a Defesa Aeroespacial do Território Nacional; e executar a vigilância do Espaço Aéreo Brasileiro (Força Aérea Brasileira, 2007c).

${ }^{128}$ A Lei do Tiro de Destruição foi fortemente criticada por juristas que a consideram inconstitucional uma vez que sua autorização equivaleria à aplicação da pena de morte, o que é expressamente vedada pela Constituição brasileira. Sobre a opinião dos juristas que se opõe à aplicação da Lei do Tiro de Destruição ver: Lima (2007) e Assis (2007). A Lei 9.614 também encontrou resistência no Congresso Nacional. O deputado Átila Lins (2003) apresentou um projeto pedindo a revogação desta lei em 2003. 
E um Acordo Quadro sobre Cooperação em Matéria de Defesa. Celebrado em 09 de novembro de 2006, em Brasília.

O memorando em questão é uma contribuição para o avanço na construção de uma aliança estratégica entre o Brasil e o Peru visando o controle sobre o espaço amazônico dos respectivos territórios e o combate eficaz de atos ilícitos produzidos, entre outros, pelos agentes do narcotráfico. Pelo que foi acordado o governo brasileiro se compromete a facilitar o acesso progressivo do Peru aos dados gerados pelo SIVAM e a integração peruana ao SIPAM. Compromete-se também a oferecer a assistência técnica necessária para a implementação de um sistema similar ao SIVAM na cidade de Pucalpa no Peru. Este sistema permitirá o intercâmbio em tempo real de dados de radar na faixa de fronteira comum, com a finalidade de vigiar e controlar o espaço aéreo naquela zona, com ênfase nas atividades ilícitas (Brasil, 2006b).

Em novembro de 2006, o governo brasileiro celebrou com o Peru um Acordo Quadro sobre Cooperação em Matéria de Defesa que prevê, entre outras medidas, o intercâmbio de informações em inteligência estratégica em coordenação com os organismos de Defesa de cada país e a promoção de ações conjuntas de treinamento, instrução militar, e exercícios militares combinados (Brasil, 2007b).

Com a Colômbia, o governo brasileiro firmou um Acordo de Cooperação Mútua para o Combate ao Tráfego de Aeronaves Envolvidas com Aeronaves Envolvidas com Atividades Ilícitas Transnacionais, celebrado em 1997 na cidade de Cartagena das Índias, na Colômbia, e promulgado pelo Decreto 5.815, de 26 de junho de 2006. E um Memorando de Entendimento sobre Cooperação em Relação a Matérias de Defesa assinado em 20 de junho de 2003.

O Acordo de Cooperação Mútua para o Combate ao Tráfego de Aeronaves Envolvidas com Atividades llícitas Transnacionais celebrado pelo Brasil e a Colômbia reza que os dois países tomarão as medidas cabíveis para: 1. controlar o tráfego de aeronaves evoluindo nos respectivos espaços aéreos nacionais; e 2. intensificar o intercâmbio de informações e experiências relacionadas com o combate a aeronaves 
envolvidas com atividades ilícitas transnacionais, em especial o narcotráfico. O Estado-Maior da Aeronáutica brasileira e o Estado-Maior da Força Aérea da Colômbia foram designados para representar os dois países no cumprimento do Acordo (Brasil, 2006c).

E o Memorando de Entendimento sobre Cooperação em Relação a Matérias de Defesa determina que o Brasil e a Colômbia cooperarão e trocarão experiências nos seguintes campos: (1) pesquisa e desenvolvimento científico e tecnológico da indústria de Defesa; (2) treinamento e capacitação de recursos humanos; (3) apoio logístico; (4) organização e legislação institucionais; (5) informações operacionais; (6) intercâmbio de informação e inteligência militar; e (7) medidas de confiança mútua e segurança hemisférica (Brasil, 2007c).

Além disso, o Brasil assinou, em 2004, um Memorando Tripartite com os dois países acima citados: o Memorando de Entendimento Tripartite entre o Ministério da Defesa e o Ministério da Justiça da República Federativa do Brasil, o Ministério da Defesa Nacional da República da Colômbia e o Ministério da Defesa da República do Peru, para coibir as Atividades llícitas nos Rios Fronteiriços Comuns. Pelas regras deste memorando, os três países se comprometem a: (1) controlar o tráfego das embarcações que se desenvolva em seus respectivos rios limítrofes comuns com sujeição ao princípio de liberdade de navegação; (2) intensificar o intercâmbio de informações sobre o tráfego de embarcações presumivelmente envolvidas em delitos e contravenções a que se refira este Memorando de Entendimento; (3) Acrescentar o intercâmbio de experiências e conhecimentos técnicos relacionados com o controle de rios limítrofes comuns e de suas zonas ribeirinhas nacionais. Para executar as operações do Memorando, o Ministro da Defesa do Brasil designou o Comandante Militar da Amazônia e o Comandante do $4^{\circ}$ Distrito Naval ${ }^{129}$, o Ministro da Justiça designou o Chefe da Divisão de Controle Operacional Norte da Coordenação de Operações Especiais de Fronteiras, o Ministro da Defesa da Colômbia designou o Chefe de Operações Navais da Armada

${ }^{129}$ Cabe lembrar que o $9^{\circ}$ Distrito Naval, com sede em Manaus, ainda não havia sido criado na data da assinatura do Memorando Tripartite. 
Nacional e o Ministro da Defesa do Peru designou o Comandante Geral de Operações da Amazônia (Brasil, 2004c).

O governo brasileiro também propôs Acordos de Cooperação Mútua para o Combate ao Tráfego de Aeronaves Envolvidas com Atividades llícitas Transnacionais similares ao que foi celebrado com a Colômbia para a Bolívia, em 09 de dezembro de 2005, na cidade de La Paz (Brasil, 2007d) e para a Venezuela, também em dezembro de 2005 (Brasil, 2005b).

Ainda como um gesto de aproximação com os países amazônicos, o governo brasileiro doou, nos últimos anos, seis aeronaves T-25, de adestramento de pilotos, para a Força Aérea Boliviana (Brasil, 2005a) e cinco aeronaves C-91A, de transporte, para a Força Aérea Equatoriana (Brasil, 2006d).

No âmbito da cooperação militar, é importante frisar que, mais do que ações diplomáticas, uma aeronave está desempenhando um papel importante na aproximação do Brasil com os demais países amazônicos: o Super Tucano.

Esta aeronave foi projetada e produzida pela Embraer a partir do avião de treinamento T-27, o Tucano, a pedido da Força Aérea brasileira. O A-29, ou Super Tucano, é uma aeronave de caça patrulha e reconhecimento que pode operar em ambientes hostis a partir de pistas em condições precárias, tanto durante o dia como durante a noite. O Super Tucano pode ser considerado uma inovação tecnológica decorrente da percepção de que Amazônia precisa ser protegida de forma mais eficaz, lembrando o argumento de Evera (1998) sobre como as percepções de ameaça podem influenciar o comportamento das Forças Armadas (Força Aérea Brasileira, 2007d).

O Super Tucano tem despertado o interesse de países que, como o Brasil, enfrentam problemas com aeronaves supostamente envolvidas em atividades ilícitas transnacionais. A Força Aérea colombiana já adquiriu estas aeronaves para utilizá-las em sua "guerra" contra o tráfico de drogas e a Venezuela só não as comprou porque o A-29 utiliza componentes tecnológicos norte-americanos, e os Estados Unidos se recusam a fornecer 
equipamentos militares para o governo de Hugo Chávez. A Bolívia também mostrou interesse pelo Super Tucano, e a diplomacia brasileira tem se esforçado para concretizar o negócio vendo nisso uma possibilidade de estreitar laços com o país andino no âmbito militar (Godoy, 2007).

As operações militares que a Força Aérea brasileira realiza com a Colômbia, o Peru e a Venezuela também se inserem no esforço de aproximação dos militares brasileiros com seus pares sulamericanos. Como já foi dito no segundo capítulo, a percepção de que os problemas de segurança existentes na fronteira norte do Brasil não podem ser solucionados unilateralmente está mudando paulatinamente a postura dos militares brasileiros acerca da integração regional. Esta mudança de percepção, aliada à assinatura de tratados de cooperação com os países acima citados, levou a Aeronáutica a investir na realização de operações bilaterais destinadas a estabelecer procedimentos específicos de coordenação voltados para a Defesa Aérea da Amazônia.

As operações PERBRA, VENBRA e COLBRA seguem um roteiro padrão: empregam-se aeronaves-alvo que, simulando tráfegos ilícitos, cruzam a linha de fronteira entre o Brasil e o país convidado nos dois sentidos. Para localizá-las, são empregados meios de detecção (radares) e interceptação (aeronaves) de ambos os países. Quando o tráfego ilícito simulado cruza a fronteira, há uma coordenação operacional entre os Centros de Operações Aeroespacial dos dois países que possibilita a transferência de informações e o acompanhamento da aeronave desconhecida pela Força Aérea de um ou de outro país. ${ }^{130}$

Podemos afirmar que, das três Forças Armadas, a Força Aérea é a que mais tem avançado na cooperação militar com os nossos vizinhos amazônicos. As operações conjuntas descritas acima são um passo tímido

${ }^{130} \mathrm{O}$ desenvolvimento das operações aéreas bilaterais pode ser consultado na página oficial da Aeronáutica. A operação PERBRA II foi realizada em julho de 2006 na cidade de Cruzeiro do Sul, no Acre (Força Aérea Brasileira, 2007c). A operação COLBRA I ocorreu em maio de 2005 na cidade de São Gabriel da Cachoeira, no Amazonas (Força Aérea Brasileira, 2007e). E a operação VENBRA IV realizou-se em abril de 2006 na cidade de Boa Vista, em Roraima (Força Aérea Brasileira, 2007f). 
no caminho da integração com os países amazônicos, mas representam uma importante Medida de Confiança Mútua ${ }^{131}$ que não deve ser menosprezada.

\subsubsection{O VII COMAR}

O VII Comando Aéreo Regional foi criado no ano de 1983 pelo Decreto № 88.134, em decorrência da divisão do I COMAR (Brasil, 1983). O VII COMAR tem jurisdição sobre os estados do Amazonas, Roraima, Acre e Rondônia, sob sua direção estão as Bases Aéreas de Boa Vista (BABV), Manaus (BAMN) e Porto Velho (BAPV), o Destacamento da Aeronáutica de São Gabriel da Cachoeira (DASG), as Prefeituras de Aeronáutica de Boa Vista (PABV), Manaus (PAMN) e Porto Velho (PAPV), o $7^{\circ}$ Esquadrão de Transporte Aéreo ( $\left.7^{\circ} \mathrm{ETA}\right)$ e $\circ$ Batalhão de Infantaria da Aeronáutica Especial de Manaus (BNFAE/MN).

O destacamento da Base Aérea de Manaus (BAMN) foi criado em 1953, com a finalidade de expandir as linhas do CAN e criar um ponto de apoio às operações da $F A B$ na Amazônia (Força Aérea Brasileira, 2005d). A BAMN sedia $07^{\circ}$ Esquadrão do $8^{\circ}$ Grupo de Aviação, o Esquadrão Harpia, o $1^{\circ}$ Esquadrão do $9^{\circ}$ Grupo de Aviação, denominado Esquadrão Arara, o $7^{\circ}$ Esquadrão de Transporte Aéreo, conhecido como Esquadrão Cobra e o $4^{\circ}$ Batalhão de Aviação do Exército.

O $4^{\circ}$ Batalhão de Aviação do Exército, como já foi dito no terceiro capítulo, é uma Força de Ação Rápida do Exército. A unidade foi criada em 1993 e está locada na BAMN. O Batalhão recebeu a denominação histórica de Batalhão Coronel Ricardo Pavanello, em homenagem ao primeiro comandante da unidade (Exército Brasileiro, 2006m).

\footnotetext{
${ }^{131}$ De acordo com Francisco Rojas, as Medidas de Confiança Mútua são ações com uma vinculação de reciprocidade necessária, não necessariamente equivalente, mas sem paralelo no tempo. Neste sentido, as Medidas de Confiança Mútua não são declarações ou compromissos, são ações efetivas que podem ser avaliadas e verificadas (Rojas Avarena, 1995:06).
} 
O Esquadrão Harpia é oriundo do $51^{\text {a }}$ Esquadrilha de Reconhecimento e Ataque criada em meados da década de 1960 na Base Aérea de Canoas-RS. Em 1970 a unidade foi transferida para Belém e passou a realizar operações aéreas especiais, primordialmente antiguerrilha. Em 1980, o Harpia foi removido para Manaus. O $7^{\circ} / 8^{\circ} \mathrm{GAV}$ opera helicópteros que cumprem missões de infiltração e exfiltração de tropas, busca e salvamento e C-SAR, tanto na selva, como no mar. O Esquadrão Harpia também realiza missões de apoio sociais e humanitárias com as populações ribeirinhas e indígenas. $O 7^{\circ} / 8^{\circ} \mathrm{GAV}$ está subordino à II FAE (Força Aérea Brasileira, 2005d).

O Esquadrão Arara foi criado provisoriamente na Base Aérea de Belém em 1970, sendo transferido no mesmo ano para Manaus. O $1^{\circ} / 9^{\circ}$ GAV é o único esquadrão da FAB a operar as aoeronaves C-115, o Búfalo. Estas aeronaves realizam missões de transporte de tropas e logístico, além de missões de re-suprimento para as unidades militares localizadas em áreas de difícil acesso, onde muitas vezes não existe uma pista para aeronaves do seu porte. Os Búfalo não são velozes, mas sua robustez e autonomia favorecem a sua operação em regiões como a Amazônia que necessita de aeronaves que sejam capazes de voar longas distâncias sem reabastecer. O Arara está subordinado a $V F A E^{132}$ e atua em coordenação com o VII COMAR (Força Aérea Brasileira, 2005e).

O Esquadrão Cobra é o mais novo dos Esquadrões de Transporte Aéreo, ele foi criado em 1983, e realiza missões similares aquelas que são realizadas pelo Esquadrão Tracajá. Assim como os demais Esquadrões de Transporte, o $7^{\circ}$ ETA está subordinado diretamente ao VII COMAR (Força Aérea Brasileira, 2005f).

A cidade de Manaus também sedia um Batalhão de Infantaria da Aeronáutica, o Batalhão de Infantaria da Aeronáutica Especial de Manaus (BNFAE-MN). A Infantaria da Aeronáutica foi criada em 1941 com o objetivo de guardar, vigiar e defender as Bases Aéreas. Ao longo das

${ }^{132}$ A V Força Aérea tem sede no Rio de Janeiro e é responsável pelas unidades de transporte, reabastecimento em vôo, lançamento de pára-quedistas e apoio a unidades do Exército (Força Aérea Brasileira, 2006a). 
décadas, novas funções foram sendo atribuídas à infantaria. Atualmente, a Infantaria da Aeronáutica realização operações ofensivas, defensivas, especiais e de proteção. Além das missões tradicionais, a infantaria realiza também missões de salvamento e resgate (Valdenice, 2003).

A BABV foi ativada em 1984. Ela é até o momento a mais setentrional das bases da $F A B$ e tem como unidade aérea sediada $01^{\circ}$ Esquadrão do $3^{\circ}$ Grupo de Aviação $\left(1 \% 3^{\circ} \mathrm{GAV}\right)$, denominado Esquadrão Escorpião ${ }^{133}$. O $1 \% 3^{\circ}$ GAV tem suas origens no $7^{\circ}$ Esquadrão de Transporte Aéreo, sediado na Base Aérea de Manaus. Com a criação do VII COMAR, a unidade foi transferida para Boa Vista e em 1995 passou a integrar a Aviação de Ataque da FAB. Desde 2001, o Escorpião integra a Aviação de Caça e está subordinado à III $F A E^{134}$. Uma de suas funções mais importantes é a vigilância e o patrulhamento aéreo da região amazônica e da fronteira oeste do Brasil. Além disso, o Escorpião realiza missões de interceptação e ataque, reconhecimento armado, reconhecimento visual, ligação, observação, C-SAR ${ }^{135}$, controle aéreo aproximado e operações aéreas especiais. $\mathrm{O} \quad 1^{\circ} / 3^{\circ} \mathrm{GAV}$ também atua conjuntamente com outros órgãos do governo federal, como a Polícia Federal, com a qual o esquadrão atua no combate a vôos ilícitos, principalmente de aeronaves de contrabandistas e traficantes.

O Escorpião é um dos três esquadrões da FAB que utilizam o Super Tucano. Para cumprir suas missões de patrulhamento e vigilância, o $1^{\circ} / 3^{\circ}$ atua em conjunto com o $2^{\circ}$ Esquadrão do $6^{\circ}$ Grupo de Aviação ( $2^{\circ} / 6^{\circ} \mathrm{GAV}$ ) que está sediado na Base Aérea de Anápolis, o Esquadrão Guardião, como é mais conhecido.

O 2\% $6^{\circ}$ GAV é a ponta de lança do SIVAM, suas aeronaves são equipadas com radares para o Alerta Antecipado e Controle, os R-99A, e

\footnotetext{
${ }^{133} \mathrm{O}$ escorpião simboliza a agressividade do esquadrão no cumprimento de suas missões. ${ }^{134}$ A III Força Aérea sediada na cidade de Gama-DF coordena e gerencia o emprego de unidades aéreas de aplicação estratégica e tática, bem como as de reconhecimento e Defesa Aérea (Força Aérea, 2006a).

${ }^{135}$ Operações de resgate e salvamento atrás das linhas inimigas, em situações de combate.
} 
de Sensoriamento Remoto, os R-99B. Estas aeronaves desempenham duas missões importantes. Além de vasculharem o território coletando dados e informações que propiciam aos usuários do SIVAM a tomada de medidas corretivas, visando ao desenvolvimento sustentável da região e a proteção ao meio ambiente (Força Aérea Brasileira, 2005g), as aeronaves do $2^{\circ} / 6^{\circ}$ GAV quando detectam um avião sem plano de vôo em sua área de atuação, imediatamente interpelam sua tripulação, a fim de determinar sua intenção. Se a tripulação reagir de forma suspeita ou tentar fugir das ações das autoridades brasileiras, a aeronave radar imediatamente acionará os Super Tucanos para interceptá-las (Cambeses Júnior, 2007).

A Base Aérea de Porto Velho (BAPV) também foi ativada em 1984 dentro do esforço de expandir a presença da $F A B$ na Amazônia e abriga o $2^{\circ}$ Esquadrão do $3^{\circ}$ Grupo de Aviação $\left(2^{\circ} / 3^{\circ} \mathrm{GAV}\right)$, o Esquadrão Grifo ${ }^{136}$. O $2^{\circ} / 3^{\circ}$ GAV também deriva do $7^{\circ} \mathrm{ETA}$, ele foi criado em 1995, pertenceu à Aviação de Ataque da FAB até 2001 e hoje integra a Aviação de Caça. O Esquadrão Grifo realiza as mesmas missões que o Esquadrão Escorpião e também utiliza os Super Tucanos. O $2^{\circ} / 3^{\circ} \mathrm{GAV}$ está subordinado à III FAE (Força Aérea Brasileira, 2005h).

Juntos, os Esquadrões Guardião, Flecha ${ }^{137}$, Escorpião e Grifo compõe as unidades da FAB que estão a serviço do SIVAM. Estes

${ }^{136} \mathrm{O}$ Grifo é um animal mitológico alado que, segundo a lenda, seria consagrado ao deus Sol. Os grifos possuem tronco de leão, cabeça de cordeiro, orelha de cavalo e bico de águia. Cada característica do animal tem um significado: o leão representa o poder máximo no reino animal, o cordeiro é considerado um animal sagrado, o cavalo é tido como o animal mais dócil e servil ao homem, a águia representa altivez e impiedade com os inimigos. $\mathrm{Na}$ lenda, o grifo protege os templos sagrados, ricos em metais e pedras preciosas, dos saqueadores e violadores. Por suas habilidades especiais, o grifo foi escolhido pelo $2^{\circ} / 3^{\circ}$ GAV para representar suas missões: "Esquadrão Grifo, guardião da Pátria e das riquezas amazônicas, soberano no Espaço Aéreo Brasileiro (Aerovisão, 1999:17)".

${ }^{137} \mathrm{O} 3^{\circ}$ Esquadrão do $3^{\circ}$ Grupo de Aviação $\left(3^{\circ} / 3^{\circ} \mathrm{GAV}\right)$, o Esquadrão Flecha, foi criado em 2004 e está sediado na Base Aérea de Campo Grande. O Esquadrão foi formado a partir do efetivo do da extinta $2^{\underline{a}}$ Esquadrilha de Ligação e Observação (2ª ELO), locada na Base Aérea de Santa Cruz-RJ. O Flecha tem como uma de suas missões mais importantes a vigilância da fronteira oeste do país, que abrange as fronteiras com o 
esquadrões também desempenham um relevante papel de diplomacia militar pois participam das operações aéreas bilaterais realizadas na região amazônica. Em relação ao Escorpião e ao Grifo, é importante ressaltar que estes esquadrões seguiram um caminho inverso ao da aviação de patrulha no Pós-Guerra. Pensados, inicialmente, para atuar no transporte aéreo, eles foram convertidos em aviação de patrulha, mostrando que esta é a prioridade da Força Aérea na Amazônia atualmente. Passemos agora à análise da presença da Marinha na Amazônia.

\section{A Marinha na Amazônia}

Caso esta tese estivesse utilizando uma abordagem neorealista para explicar a presença militar na Amazônia, estudar o comportamento da Marinha brasileira seria a melhor forma de comprovar a força interpretativa desta perspectiva teórica, pois, de maneira geral, a Marinha empreende seus esforços na Amazônia de acordo com as mudanças detectadas no ambiente internacional. No discurso oficial da Força, a criação da Flotilha do Amazonas foi uma resposta à abertura da navegação do rio Amazonas às nações amigas, em 1867. A Segunda Guerra Mundial impulsionou a criação do $4^{\circ}$ Distrito Naval $\left(4^{\circ} \mathrm{DN}\right)$, uma unidade operacional da Marinha, no Pará. Já a divisão do dito Distrito e a ativação do $9^{\circ}$ Distrito Naval em Manaus, no ano de 2005, podem ser interpretadas como ações reativas da Marinha às novas ameaças que rondam a Amazônia. Entretanto, outros elementos devem ser agregados para que se possa compreender melhor o comportamento da Marinha brasileira na região.

Dois fatores devem ser levados em conta sempre que se discute a postura estratégica das Forças Armadas brasileiras: (1) as relações civismilitares; (2) a cultura organizacional de cada Força. No plano das relações

Paraguai e a Bolívia, complementando o trabalho realizado pelos Esquadrões Escorpião e Grifo, os responsáveis pela vigilância da fronteira norte. $\mathrm{O} 3^{\circ} / 3^{\circ} \mathrm{GAV}$ também é uma unidade de formação de líderes de Esquadrilhas de Caça da FAB e está subordinado à III FAE (Força Aérea Brasileira, 2006h). 
civis-militares a literatura brasileira já consolidou a tese de que devido a pouca atenção dispensada aos assuntos de Defesa Nacional pelos políticos civis, os militares brasileiros definem suas prioridades estratégicas com um elevado grau de autonomia institucional ${ }^{138}$. Esta autonomia faz com que os fundamentos da cultura institucional de cada uma das três Forças prevaleçam na estrutura militar brasileira.

Os documentos sobre Política de Defesa Nacional aprovados em 1996 e 2005 ratificam esta hipótese. Em ambos os documentos a Amazônia e o Atlântico Sul aparecem como áreas prioritárias para a Defesa Nacional. Sendo a Amazônia um teatro de operações terrestre ${ }^{139}$ e o Atlântico Sul um teatro de operações marítimo, é compreensível que o Exército tenha um papel prioritário na preparação da Defesa da Amazônia e a Marinha dedique mais atenção ao espaço geoestratégico do Atlântico Sul. Entretanto, essa "divisão de trabalho" entre as duas Forças Armadas tem um significado mais amplo.

Se é compreensível que a Marinha assuma o papel principal no teatro do Atlântico Sul, também é esperado que a Força, sem descurar de seu teatro de operações principal, esteja mais presente na Amazônia, já que a região é vista como a principal vulnerabilidade estratégica do país. No entanto, desde que o Programa Calha Norte foi instituído, as únicas iniciativas de monta da Marinha na Amazônia foram a ativação do $9^{\circ}$ Distrito Naval e a transformação do Grupamento de Fuzileiros Navais de Manaus em Batalhão de Operações Ribeirinhas, recentemente.

Também chama a atenção que a Marinha brasileira, sendo coresponsável pela parte operacional do Memorando de Entendimento Tripartite assinado pelo Brasil, Colômbia e Peru, em 2004, para coibir as atividades ilícitas nos rios fronteiriços comuns, ainda não tenha tomado

\footnotetext{
${ }^{138}$ Sobre esta tese, ver especialmente Oliveira (1994).

${ }^{139}$ O Almirante Vidigal questiona esta conceituação do teatro de operações amazônico: "A Marinha reconhece, por exemplo, que um Comando unificado na Amazônia deve ser do Exército. Eu gostaria de discutir um pouco mais este problema. Por que um Comando unificado na Amazônia deve ser do Exército, se todo sistema logístico é fluvial? (Vidigal, 2007)".
} 
nenhuma medida no sentido de propor e realizar operações navais com esses países a fim de criar e testar procedimentos comuns que permitam cumprimento das novas missões estabelecidas pelo Memorando ${ }^{140}$.

Vale lembrar que a Aeronáutica, quando confrontada com uma situação semelhante, por ocasião das assinaturas de acordos bilaterais para coibir o tráfego de aeronaves envolvidas em atividades ilícitas na Amazônia, buscou incrementar a cooperação com as Forças Aéreas dos países amazônicos através da realização de operações aéreas com os mesmos.

Outro indício do papel secundário ocupado pela Amazônia no pensamento da Marinha é a escassez de bibliografia produzida pela Força a respeito deste tema. Uma pesquisa bibliográfica feita a partir do terminal de computadores da Escola de Guerra Naval no início de 2007 detectou a existência de pouquíssimas monografias de final de curso que tratam da Amazônia $^{141}$. A Revista Marítima Brasileira, principal publicação da Marinha, também dedicou poucas páginas à temática amazônica e quando o fez, na maioria das vezes por meio de seus almirantes, foi para reforçar a mitologia militar sobre a região, que já discutimos no segundo capítulo ${ }^{142}$.

\footnotetext{
${ }^{140}$ Num artigo publicado na Revista Marítima Brasileira, em 1998, o Serviço de Relações Públicas da Marinha aponta como uma das tarefas executadas pela Força na Amazônia, a realização de operações conjuntas com as Marinhas da Colômbia, Peru e Venezuela. No entanto, a seção do portal eletrônico da Marinha do Brasil que disponibiliza informações sobre as operações navais, registra notícias somente da operação VENBRAS, realizada pelas Armadas do Brasil e da Venezuela, em outubro de 2004, na área marítima entre Salvador e Fortaleza, e não nos rios da Amazônia (Marinha do Brasil, 2006a).

${ }^{141}$ O levantamento feito a partir do ano de 1970 encontrou apenas três monografias que tinham a Amazônia como objeto principal do trabalho: Braga (1972), Oliveira (1972) e Hollanda (2004).

${ }^{142}$ Ver especialmente os seguintes artigos: Fortuna (1994) e (2003); Silva (2000), (2001), (2004); Guimarães (2003) e Vidigal (2002). Fugindo um pouco deste padrão, o vicealmirante José Luiz Feio Obino, ex-comandante do $4^{\circ}$ Distrito Naval publicou dois artigos em 1998 propondo uma maior presença da Marinha na Amazônia: Obino (1998a) e (1998b). E o artigo do capitão-de-fragata Maurício Kiwielewicz (1997), do corpo de engenharia, propõe um modelo matemático baseado em equações diferenciais ordinárias para servir de subsídio para um sistema de informações no caso de um combate na selva
} 
Nem mesmo a prestação de assistência hospitalar e odontológica às populações ribeirinhas da Amazônia feita pelos navios hospital, uma ação cívico-social que confere um grande prestígio à Força, é explorada na Revista Marítima Brasileira. Embora a Marinha, assim como as outras duas Forças Armadas, reivindique para si o papel de primeira e, às vezes, única presença estatal na região amazônica, foi encontrado apenas um depoimento pessoal sobre as atividades assistencialistas da Marinha no levantamento bibliográfico feito na Revista Marítima Brasileira (Monteiro; Queiroz, 2003).

A lenta resposta organizacional da Marinha à crescente importância da Amazônia no cenário estratégico nacional não deixa de ser intrigante. Qual será então motivo dessa inércia? Acreditamos que a identidade institucional da Marinha desempenha um papel importante nesta questão.

Tida como a mais profissional das três Forças, por ser o ramo militar brasileiro que mais se aproxima do profissionalismo castrense clássico, ou seja, uma Força Militar que desempenha funções estritamente voltadas para a defesa externa. A Marinha construiu sua identidade institucional e adequou os seus meios tendo como referência o que no jargão militar se denomina uma Marinha de águas azuis, ou seja, uma Marinha capaz de operar em mar aberto, longe de suas bases de apoio. A este respeito, o almirante Vidigal pondera:

A Marinha comete um erro. A Marinha comete um erro no sentido de que ela sempre defendeu a Marinha de águas azuis, a Marinha oceânica, e sempre desprezou a Marinha interiorana, a Marinha dos rios, esquecendo que a Guerra do Paraguai foi toda uma guerra fluvial, que as nossas grandes vitórias são fluviais: Riachuelo, passagem de Humaitá, tudo é fluvial. Na guerra Cisplatina também, a passagem de Toneleros, tudo é fluvial. A Marinha se esquece da experiência do passado e se apóia numa Marinha oceânica. A gente até entende isso, a Marinha oceânica é uma grande Marinha, uma Marinha que vai a qualquer lugar do mundo. Mas o nosso problema de Defesa é tanto

amazônica. Os outros artigos da Revista Marítima brasileira que apresentam alguma contribuição para o entendimento da estratégia militar da Marinha para a Amazônia estão citados ao longo deste capítulo. 
fluvial quanto marítimo, e nós não podemos abandonar o problema fluvial, mas a Marinha, de certa forma, o abandonou (Vidigal, 2007).

A Marinha brasileira não apenas renega sua herança operacional ribeirinha, como, nos últimos anos, reivindica a existência de uma outra Amazônia "maior que a verde e inimaginavelmente rica" que deve ser protegida: a Amazônia Azul.

\subsection{A Amazônia Azul}

O termo Amazônia Azul foi cunhado pelo ex-comandante da Marinha Roberto de Guimarães Carvalho para denominar as águas jurisdicionais brasileiras e as riquezas que ela comporta. Esta área compreende o Mar Territorial brasileiro, um espaço sobre o qual o Brasil possui soberania plena, a Zona Econômica Exclusiva, sobre a qual o Brasil tem direitos de soberania para fins de exploração e aproveitamento, conservação e gestão dos recursos naturais, e a Plataforma Continental, sobre a qual o Brasil possui o direito de soberania para exploração e aproveitamento dos recursos naturais.

O Mar Territorial deve ser medido a partir das linhas de base e não deve ultrapassar o limite das 12 milhas marítimas. A Zona Contígua tem o limite máximo de 24 milhas. A Zona Econômica Exclusiva permite a exploração e aproveitamento dos recursos naturais, vivos e não-vivos, das águas sobrejacentes ao leito do mar, do solo e do subsolo marinhos e, no que se refere a outras atividades, para fins econômicos, como a produção de energia a partir da água, as correntes marítimas e dos ventos; e jurisdição sobre: (1) a colocação e utilização de ilhas artificiais, instalações e estruturas, (2) a investigação científica marinha, e (3) proteção e prevenção do meio marinho. E a Plataforma Continental permite a exploração e aproveitamento dos recursos naturais. Estes recursos são os recursos minerais e outros não vivos do solo e subsolo marinho, e também os organismos vivos pertencentes a espécies sedentárias que no período de captura estão imóveis nessa mesma região, ou só podem mover-se em 
constante contato físico com ela (Vidigal et al, 2006:34-44). A próxima figura mostra a área marítima sobre a qual o Brasil possui algum tipo de jurisdição ${ }^{143}$.

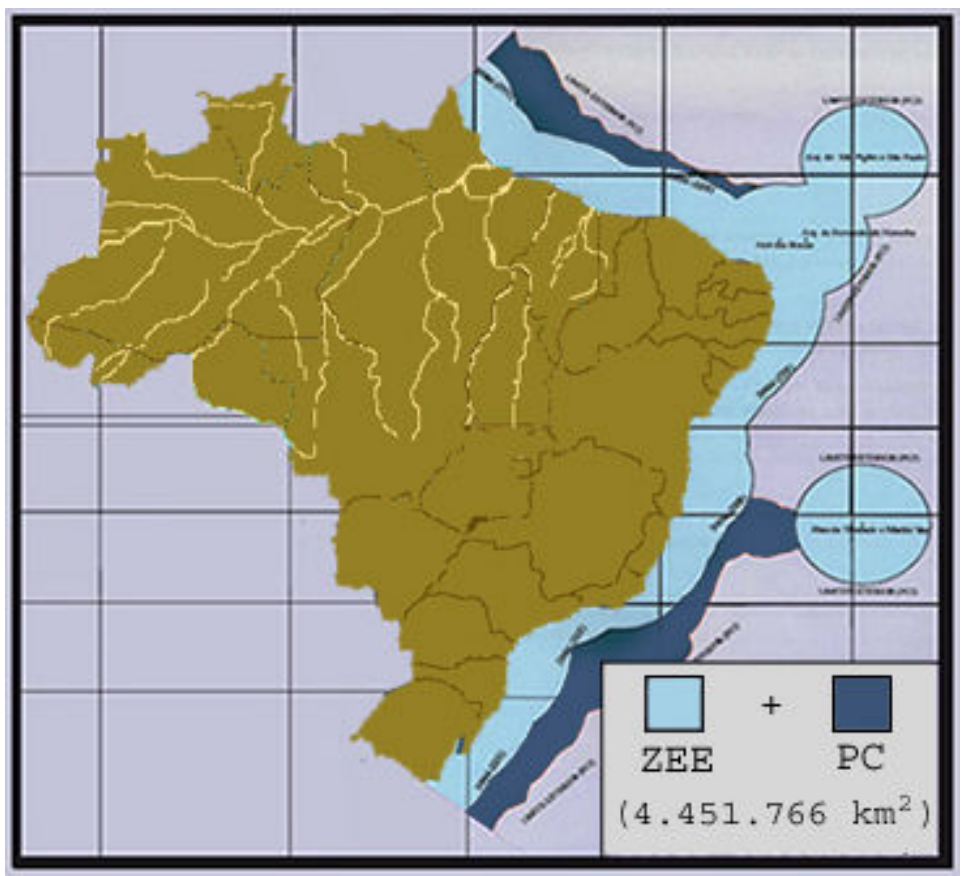

Figura 10 - Amazônia Azul

Fonte: Marinha do Brasil (2006b)

Ainda que 0 almirante Carvalho negue que 0 uso da expressão Amazônia Azul tenha o propósito de criar um disputa com a Amazônia Verde (Carvalho, 2005), É inegável que o uso da palavra Amazônia, como sinônimo de riquezas naturais, tem o objetivo de chamar a atenção dos governantes e da sociedade brasileira para o cenário estratégico que a Marinha considera prioritário:

${ }^{143}$ A Convenção das Nações Unidas sobre o Direito do Mar de 1982 é o marco na regulamentação do uso do mar pelos países costeiros. O livro Amazônia Azul: o mar que nos pertence, traz informações detalhadas sobre todo este processo de regulamentação. Ver: Vidigal et al (2006). 
E aí é que você sente o porquê da nossa ênfase na Amazônia Azul. Porque de repente a Amazônia Verde tomou conta da consciência nacional. Hoje todo mundo tem conhecimento da situação da Amazônia. O Jornal do Brasil ${ }^{144}$ está fazendo uma campanha retórica sobre a invasão da Amazônia, quer dizer, a Amazônia Verde tomou conta da consciência nacional. Quando nós criamos o termo Amazônia Azul é para dizer: não olhem apenas para a Amazônia Verde, olhem para a Amazônia Azul também. Nós temos ameaças à Amazônia Azul, nós temos riquezas a proteger na Amazônia Azul. Não se esqueçam da Amazônia Azul. Este é o grande objetivo do termo Amazônia Azul (Vidigal, 2007).

Mas voltemos agora ao objeto desta tese, ou seja, a presença da Marinha na Amazônia Verde.

\subsection{Mito de origem e realidade histórica da presença naval na Amazônia}

No discurso oficial da Marinha, as operações ribeirinhas são realizadas na Amazônia desde o período colonial. Assim como o Exército, a Marinha recupera os feitos de Pedro Teixeira, o "Conquistador da Amazônia" para criar um mito sobre as primeiras operações militares da Marinha na região.

De acordo com mito institucional da Marinha, em 09 de agosto de 1616, os então alferes Pedro Teixeira e Gaspar de Freitas, comandando "marujos e soldados" realizaram a primeira operação ribeirinha das forças luso-brasileiras:

Com duas canoas armadas em guerra, bateram uma nau holandesa na foz do Xingu, enfrentando fogo cerrado de artilharia, que não poderiam superar, não fosse a criatividade de Pedro Teixeira. A artilharia da nau

${ }^{144}$ O Jornal do Brasil publicou uma série de artigos intitulada Amazônia em Perigo na última semana de janeiro de 2007. Desta série ver especialmente: Carneiro (2007a) e (2007b), Cavour (2007), Nunes (2007), Pereira (2007a) e (2007b). 
holandesa afundada foi mais tarde usada para armar o Forte do

Presépio (Marinha do Brasil, 2007a) ${ }^{145}$.

Pedro Teixeira, portanto, na mitologia militar além de ser precursor da estratégia da resistência, é também o pai das operações ribeirinhas na Amazônia ${ }^{146}$. E os inimigos que foram derrotados pelo "Conquistador da Amazônia", mais uma vez, são os temidos holandeses, detentores da Armada mais poderosa do mundo naquele período histórico.

Já a primeira organização militar da Marinha "luso-brasileira", ainda segundo o discurso oficial, data de 1728, quando o Governador das Províncias do Maranhão e Grão-Pará, Alexandre de Souza Freire, decidiu criar a Divisão Naval do Norte em Belém. Em termos históricos, a primeira unidade militar da Marinha brasileira na Amazônia foi criada em 1868: a Flotilha do Amazonas (Flotam), responsável pela proteção do litoral e das vias interiores da região amazônica. Alternando a localização entre Manaus e Belém, a Flotam está baseada em Manaus desde 1974 (Marinha do Brasil, 2007a).

Com a conflagração da Segunda Guerra Mundial, o governo brasileiro decidiu criar o Comando Naval do Amazonas, com sede em Belém. Em 1942, esse Comando foi substituído pelo Comando Naval do Norte, com jurisdição sobre os estados do Acre, Amazonas, Pará, Maranhão e Piauí. A partir de 1945, esse órgão recebeu a denominação de Comando do $4^{\circ}$ Distrito Naval, que perdura até hoje (Marinha do Brasil, 2007a).

\subsection{Estrutura organizacional da Marinha na Amazônia na atualidade}

O principal órgão operativo da Marinha é o Comando de Operações Navais (ComOpNav). Subordinado diretamente ao Comandante da Marinha, o ComOpNav é composto por nove Distritos Navais (DN), o Comando-em-Chefe da Esquadra e o Comando da Força de Fuzileiros da

\footnotetext{
${ }^{145}$ O Forte do Presépio fica na cidade de Belém-PA.

${ }^{146}$ Pedro Teixeira também dá nome a uma classe de navios de patrulha fluvial.
} 
Esquadra. $\mathrm{O} 1^{\circ}$ Distrito Naval está sediado na cidade do Rio de Janeiro, o $2^{\circ}$ Distrito Naval em Salvador-BA, o $3^{\circ}$ Distrito Naval em Natal-RN, o $4^{\circ}$ Distrito Naval em Belém-PA, o $5^{\circ}$ Distrito Naval em Rio Grande-RS, o $6^{\circ}$ Distrito Naval em Ladário-MS, o $7^{\circ}$ Distrito Naval em Brasília-DF, o $8^{\circ}$ Distrito Naval na cidade de São Paulo e o $9^{\circ}$ Distrito Naval em Manaus-AM.

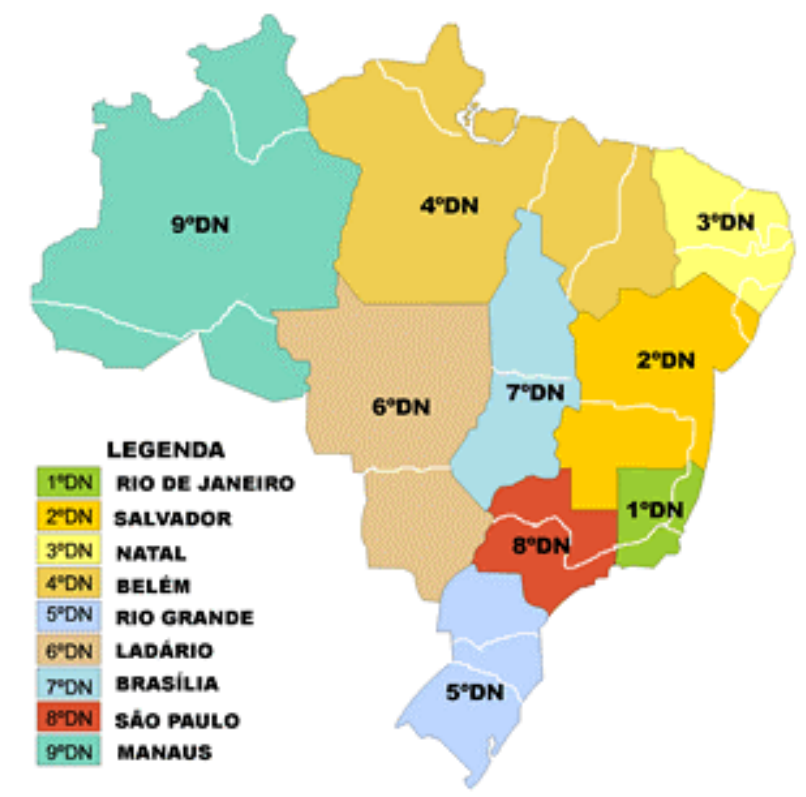

Figura 11 - Mapa das Organizações Militares da Marinha

Fonte: Marinha do Brasil (2005)

O $4^{\circ}$ DN foi criado em 1933 e sua jurisdição se estende sobre os estados do Pará, Amapá, Maranhão e Piauí. O $4^{\circ}$ DN desempenha as seguintes tarefas: I - executar operações navais, aeronavais, de fuzileiros navais e terrestres de caráter naval; II - apoiar as Unidades e Forças Navais, Aeronavais, e de Fuzileiros Navais, subordinadas ou não, em sua área de jurisdição; III - executar as atividades estabelecidas no Sistema de Mobilização Marítima; IV - executar atividades de Inteligência e de ContraInteligência; V - acompanhar o tráfego marítimo; VI - controlar as atividades relacionadas com a segurança da navegação costeira; VII - supervisionar as atividades de Patrulha Costeira, de Polícia Naval, e Socorro e Salvamento Marítimo; VIII - cooperar para a preservação e utilização racional dos recursos do mar, da plataforma continental e das águas interiores; IX - executar atividades estabelecidas na Lei do Serviço Militar; X 
- concorrer para a manutenção da Segurança Interna ${ }^{147}$ em coordenação com as demais Forças Singulares; XI - apoiar o pessoal militar e civil da Marinha e seus dependentes no que couber; XII - colaborar com as atividades de defesa civil; XIII - estimular e apoiar as atividades de interesse do poder marítimo; XIV - supervisionar as atividades de Assistência Cívico-Social das populações ribeirinhas; XV - exercer as atribuições relativas a Comando Redistribuidor (Marinha do Brasil, 2007b).

A maioria das unidades do $4^{\circ}$ Distrito Naval está sediada no Pará ${ }^{148}$, a saber: 1. Base Naval de Val-de-Cães ${ }^{149}, 2$. Comando do Grupamento Naval do Norte, 3. Capitania dos Portos da Amazônia Oriental ${ }^{150}$, 4. Centro de Instrução Almirante Braz de Aguiar (CIABA) $)^{151}$, 5. Hospital Naval de Belém, 6. Grupamento de Fuzileiros Navais de Belém, 7. Serviço de Sinalização Náutica do Norte, 8. Depósito Naval de Belém, 9. Estação Radiogoniométrica da Marinha em Belém, 10. Delegacia de Capitania Fluvial de Santarém ${ }^{152}$.

${ }^{147}$ Curiosamente, nos textos retirados do portal eletrônico da Marinha brasileira, o termo segurança interna, já em desuso, continua a ser utilizado para designar as ações de garantia da lei e da ordem (GLO).

${ }^{148}$ O Amapá conta apenas com a Delegacia da Capitania dos Portos em Santana. O Maranhão com a Capitania dos Portos do Maranhão e o Piauí com a Capitania dos Portos do Piauí (Marinha do Brasil, 2007c).

${ }^{149}$ A Base Naval de Val-de-Cães foi criada em 1950 ocupando as antigas instalações da "Casa das Canoas", fundada em 1729 por Alexandre Souza Freire, em Belém. A Base Naval tem como missão prestar apoio logístico às Forças e unidades da Marinha que operem nas águas marítimas, fluvial ou ribeirinha sob jurisdição do $4^{\circ} \mathrm{DN}$ (Marinha do Brasil, 2007d).

${ }^{150}$ À Capitania dos Portos cabe cumprir e fazer cumprir a legislação, os atos e as normas, nacionais e internacionais, que regulam os tráfegos marítimo, fluvial e lacustre (Marinha do Brasil, 2007f).

${ }^{151} \mathrm{O}$ CIABA forma os oficiais da Marinha Mercante.

152 É função das Capitanias Fluviais aplicar a legislação e normas referentes a praticagem, tráfego marítimo, segurança da navegação, do material e pessoal da Marinha Mercante, exercer a Polícia Naval e auxiliar o serviço de socorro marítimo a fim de contribuir para o controle do uso das áreas fluviais e lacustres sob sua jurisdição e defesa do tráfego de interesse nacional nessas áreas (Marinha do Brasil, 2007h). 
Destas unidades, são consideradas unidades operacionais, o Grupamento de Fuzileiros Navais de Belém e o Grupamento Naval do Norte. O Grupamento de Fuzileiros Navais de Belém é oriundo da Segunda Companhia Regional de Fuzileiros Navais do Rio de Janeiro e começou a ser transferido para Belém em 1933. O Corpo de Fuzileiros Navais realiza operações navais e terrestres de caráter naval, operações ribeirinhas, operações de defesa de portos, bases e instalações navais e operações de segurança interna (Marinha do Brasil, 2007g).

O Grupamento Naval do Norte foi criado em decorrência da divisão da Flotilha do Amazonas, no ano de 1975, e comporta a maioria dos meios (navios) do $4^{\circ} \mathrm{DN}$. O Grupamento Naval do Norte é a única Força da Marinha cujas atividades se desenvolvem simultaneamente em ambiente marítimo e fluvial. Sua missão é realizar socorro e salvamento, operações ribeirinhas, operações de defesa de porto, patrulha costeira e fluvial (Marinha do Brasil, 2007e). O Grupamento conta com os seguintes navios: 1. Rebocador de Alto-Mar Almirante Guilhem ${ }^{153}$, 2. Navio-Auxiliar Pará ${ }^{154}$, 3. Navio Patrulha Bracuí ${ }^{155}$, 4. Navio Patrulha Bocaina ${ }^{156}, 5$. Navio Patrulha Guanabara $^{157}$, 6. Navio Patrulha Guarujá ${ }^{158}$, 7. Navio Patrulha Pampeiro ${ }^{159}$, 8. Navio Patrulha Parati ${ }^{160}$ (Marinha do Brasil, 2007i).

O Serviço de Sinalização Náutica do Norte também possui embarcações próprias: o Navio Hidroceanográfico Garnier Sampaio e o Navio-Balizador Tenente Castelo. Além disso, o $4^{\circ} \mathrm{DN}$ possui um Navio

\footnotetext{
${ }^{153} \mathrm{O}$ almirante Guilhem foi incorporado à Marinha em 1981.

${ }^{154}$ O Pará é um navio de transporte fluvial equipado para executar ações cívico-sociais e transportar tropas de fuzileiros navais. Ele é fruto de uma parceria do governo estadual do Pará, que cedeu o Catamarã Pará, e a Marinha que o remodelou para atender às suas necessidades em 2005.

${ }^{155}$ O Bracuí foi incorporado à Marinha em 1998.

${ }^{156}$ O Bocaina também foi incorporado à Marinha em 1998.

${ }^{157}$ O Guanabara foi incorporado ao $4^{\circ} \mathrm{DN}$ em 1999.

${ }^{158}$ O Guarujá foi incorporado ao $4^{\circ} \mathrm{DN}$ em 1999.

159 O Pampeiro foi incorporado à Marinha no início da década de 1970.

${ }^{160}$ O Parati foi incorporado à Marinha em 1971.
} 
Museu: a Corveta Solimões, desativada recentemente (Marinha do Brasil, 2007i).

O $9^{\circ}$ Distrito Naval é a mais nova organização operacional da Marinha brasileira. Ela retoma a antiga tradição fluvial da Força, preparando seus meios para operar nas águas interiores . O $9^{\circ} \mathrm{DN}$ foi criado em $2005 \mathrm{e}$ desempenha as seguintes tarefas: I - executar operações navais, aeronavais, de fuzileiros navais e terrestres de caráter naval; II - apoiar as Unidades e Forças Navais, Aeronavais, e de Fuzileiros Navais, subordinadas ou não, em operação na Amazônia Ocidental; III - executar as atividades estabelecidas no Sistema de Mobilização Marítima, no que Ihe couber; IV - executar atividades de Inteligência e de Contra-Inteligência; V - acompanhar o tráfego fluvial; VI - controlar as atividades relacionadas com a segurança da navegação fluvial e lacustre; VII - coordenar e controlar as atividades de Patrulha Fluvial, Inspeção Naval e Socorro e Salvamento nas hidrovias interiores; VIII - cooperar para a preservação e utilização racional das águas interiores; IX - executar atividades estabelecidas na Lei do Serviço Militar; X - concorrer para a manutenção da Segurança Interna em coordenação com as demais Forças Singulares; XI apoiar o pessoal militar e civil da Marinha e seus dependentes; XII colaborar com as atividades de Defesa Civil; XIII - estimular e apoiar as atividades de interesse do Poder Marítimo; XIV - orientar, coordenar e controlar as atividades de Assistência Cívico-Social às populações ribeirinhas; XV - exercer as atribuições relativas a Comando Controlador e Comando Redistribuidor das Organizações Militares subordinadas (Marinha do Brasil, 2007j).

Estão subordinadas diretamente ao $9^{\circ} \mathrm{DN}$ sete organizações militares: 1. Comando da Flotilha do Amazonas, 2. Capitania Fluvial da Amazônia Ocidental, 3. Batalhão de Operações Ribeirinhas, 4. Capitania Fluvial de Tabatinga, 5. Estação Naval do Rio Negro, 6. Depósito Naval de Manaus, 7. $3^{\circ}$ Esquadrão de Helicópteros de Emprego Geral (Marinha do Brasil, 2007l). Entre estas organizações, são operacionais a Flotilha do Amazonas, $\circ 3^{\circ}$ Esquadrão de Helicópteros de Emprego Geral e o Batalhão de Operações Ribeirinhas. 
A Flotilha do Amazonas tem como missões executar operações ribeirinhas; efetuar patrulha naval nos rios Amazonas, Negro e Solimões; prover assistência hospitalar às populações ribeirinhas e; colaborar na fiscalização da operação de embarcações na área fluvial sob jurisdição do $9^{\circ}$ DN (Marinha do Brasil, 2007n). A Flotilha é formada pelos seguintes navios: 1. Navio Patrulha Fluvial Roraima ${ }^{161}$, 2. Navio Patrulha Fluvial Rondônia ${ }^{162}$, 3. Navio Patrulha Fluvial Amapá ${ }^{163}$ 4. Navio Patrulha Fluvial Teixeira $^{164}$, 5. Navio Patrulha Fluvial Raposo Tavares ${ }^{165}$, 6. Navio de Assistência Hospitalar Doutor Montenegro ${ }^{166}$, 7. Navio de Assistência Hospitalar Oswaldo Cruz ${ }^{167}$, 8. Navio de Assistência Hospitalar Carlos Chagas $^{168}$ (Marinha do Brasil, 2007l).

No discurso institucional da Marinha, a primeira operação da Aviação Naval na Amazônia foi realizada em 1933, quando três aviões da $4{ }^{a}$ Divisão de Esclarecimento e Bombardeio partiram do Rio de Janeiro para auxiliar na declaração de neutralidade brasileiro no conflito entre Peru e Colômbia denominado "Incidente de Letícia". Mas somente na década de 1970, mais precisamente quando a Marinha Brasileira incorporou os Navios de Patrulha Fluvial Teixeira e Raposo Tavares, foi criada uma unidade aérea da Marinha região: o Destacamento Aéreo da Flotilha do Amazonas, que data de 1979.

Finalmente, em 1994, foi criado $03^{\circ}$ Esquadrão de Helicópteros de Emprego Geral. Este esquadrão é a primeira unidade aérea da Marinha construída fora da Base Aérea Naval de São Pedro da Aldeia com o

\footnotetext{
${ }^{161}$ O Roraima foi incorporado à Marinha em 1975.

162 O Rondônia também foi incorporado à Marinha em 1975.

${ }^{163}$ O Amapá foi incorporado à Marinha em 1976.

${ }^{164}$ O Teixeira foi incorporado à Marinha em 1973.

${ }^{165}$ O Raposo Tavares também foi incorporado à Marinha em 1973.

${ }^{166}$ O Doutor Montenegro teve sua construção encomendada pelo Ministério da Saúde, em 1997. Ele serviu ao governo do Estado do Acre até 2000, quando foi cedido para Marinha.

${ }^{167}$ O Oswaldo Cruz também foi encomendado pelo Ministério da Saúde e transferido para a Marinha em 1984 por meio de um convênio.

${ }^{168}$ O Carlos Chagas também deriva do convênio firmado entre a Marinha e o Ministério da Saúde em 1984.
} 
propósito de contribuir para a aplicação do poder naval na área de atuação da Flotilha do Amazonas. Ele tem as seguintes missões: (1) patrulha naval a bordo dos navios de patrulha fluvial; (2) assistência às populações ribeirinhas a bordo dos navios de assistência hospitalar; (3) apoio às inspeções navais realizadas pela Capitania Fluvial da Amazônia Ocidental; (4) operações em apoio ao Batalhão de Operações Ribeirinhas; (5) Apoio às unidades do $4^{\circ} \mathrm{DN}$; (6) missões de emprego geral; e (7) busca e salvamento (Petró; Pereira Júnior, 2005:13).

\subsection{O Batalhão de Operações Ribeirinhas}

O Batalhão de Operações Ribeirinhas é oriundo do Grupamento de Fuzileiros Navais de Manaus, criado em 1985. Cabe ao Batalhão realizar operações ribeirinhas, prover guarda e proteção às instalações navais e civis de interesse da Marinha na região e realizar ações de segurança interna, a fim de contribuir para a segurança da área sob jurisdição do $9^{\circ}$ DN e para a garantia do uso dos rios Solimões, Amazonas e das hidrovias secundárias, atingíveis a partir da calha principal desses dois rios (Marinha do Brasil, 2007m).

No entendimento da Marinha brasileira, as operações ribeirinhas são as ações realizadas nas calhas navegáveis com a finalidade de manter um eficaz controle de hidrovias e das áreas terrestres de suas margens, absolutamente necessárias à segurança da singradura ${ }^{169}$ dos navios em ação (Elia, 2000:83). Estas operações são conduzidas em um teatro de operações não-marítimo, ou seja, são operações realizadas por forças navais em proveito da campanha de outros Comandos. Elas podem ser singulares ou combinadas (Pacheco Filho, 2005:189). No caso da Amazônia, como já foi dito, o teatro de operações é terrestre, portanto as operações ribeirinhas são realizadas em proveito da campanha do Exército. A doutrina de emprego das operações ribeirinhas começou a desenvolvida

${ }^{169}$ Singradura é a navegação feita num mesmo rumo (Ferreira, 1999:1861). 
no âmbito do $4^{\circ}$ DN na década de 1990, e vem sendo testada através da realização de operações militares como a RIBEIREX.

A operação RIBEIREX é realizada desde o início da década de $1990^{170}$. Assim como o Exército, a Marinha, o Corpo de Fuzileiros Navais em especial, a princípio buscou inspiração na experiência vietnamita, tentando adaptá-la à Amazônia brasileira (Santos, 1994). Após mais de uma década de pesquisa doutrinária, a Marinha identificou algumas peculiaridades do teatro de operações amazônico que o diferencia sobremaneira do teatro de guerra asiático. A mais importante diz respeito à densidade populacional:

O Vietnã é densamente povoado, sendo as distâncias no teatro de operações relativamente pequenas. Na Amazônia, a população é extremamente rarefeita na maior parte da região e as distâncias enormes. No Vietnã, a guerrilha possuía razoável facilidade em obter apoio logístico da população local, o que não aconteceria na Amazônia (Guimarães; Conceição Júnior, 2001:197).

Além da questão populacional, o ambiente amazônico impõe uma série de condicionantes à utilização de embarcações na área. Para superar essas dificuldades, a doutrina de emprego da Marinha para operações ribeirinhas faz algumas ponderações. Abaixo reproduzo as que mais interessam a este estudo:

1. Navio não engaja nunca. As embarcações operam apenas em áreas onde não há registro de atividades inimigas;

2. As operações se desenvolvem nas margens. Em geral os núcleos populacionais se restringem à faixa de aproximadamente $10 \mathrm{~km}$ das margens navegáveis;

3. Deve-se manter o inimigo preocupado com a própria sobrevivência. Dada a hostilidade do ambiente, a estratégia básica das operações ribeirinhas é negar ao inimigo apoio logístico, de modo que ele passe a maior parte do seu tempo buscando garantir a própria sobrevivência, não lhe dando

170 O desenvolvimento da Operação RIBEIREX 2005 pode ser acompanhado no portal eletrônico da Marinha: Marinha do Brasil (2007o). 
oportunidade de organizar operações ofensivas nem preparar sua própria defesa. Neste ponto o apoio da população local é indispensável;

4. O navio é indiscreto. $\mathrm{O}$ alto contraste visual entre o navio e o terreno torna-o um alvo aéreo e terrestre muito fácil;

5. O navio é vulnerável. Dada sua indiscrição, as restrições a sua movimentação impostas pelo canal navegável e o limitado horizonte visual, radar e rádio imposto pela vegetação, o navio é facilmente emboscado pelo inimigo;

6. As Bases Terrestres devem ser estabelecidas o mais rápido possível, sendo indispensáveis. A vulnerabilidade da base flutuante faz com que seja indispensável o estabelecimento de base terrestre para possibilitar o controle e ocupação de áreas liberadas (Guimarães; Conceição Júnior, 2001:198-199).

Em razão dessas dificuldades, a Marinha opera apenas nas calhas dos grandes rios. Embora a Marinha esteja recuperando sua tradição fluvial, abandonada depois da Guerra do Paraguai, através da realização de operações ribeirinhas singulares, como a RIBEIREX, e combinadas sob a égide do Ministério da Defesa, ainda há uma lacuna no que diz respeito à preparação da Marinha para atuar no teatro de operações amazônico. De acordo com o relato do capitão-de-corveta Pacheco, caso o Brasil venha a travar uma guerra de resistência, somente o Exército possui preparação e adestramento básico para cumprir as tarefas que lhe forem determinadas. A Marinha e a Força Aérea, ainda de acordo com o capitão Pacheco, não tem apresentado nenhuma ação nesse sentido (Pacheco, 2005).

De fato, conforme o que foi exposto neste capítulo, constatamos que a preparação da Força Aérea e da Marinha, atuando mais uma vez como coadjuvantes do Exército, está voltada para o fortalecimento da presença estatal na área. Ação de presença que se traduz nas ações cívico-sociais e nas missões de patrulhamento aéreo e fluvial realizadas por estas Forças. No próximo capítulo veremos como os formuladores de política civis interpretam os problemas de segurança e defesa na Amazônia. 


\section{CAPÍTULO V}

\section{EXECUTIVO, LEGISLATIVO E SEGURANÇA MILITAR DA AMAZÔNIA}

A idéia de que a Amazônia é cobiçada pelos estrangeiros circula nos bastidores políticos desde que as suas fronteiras foram definidas, como já comentamos no segundo capítulo. Porém, a primeira ação governamental voltada explicitamente para a proteção da área contra a "cobiça internacional" data da década de 1970: o Tratado de Cooperação Amazônica (TCA). Este capítulo analisará as percepções e iniciativas dos formuladores de política civis para a proteção da região amazônica.

\section{As iniciativas governamentais para a proteção da Amazônia}

A Conferência das Nações Unidas para o Meio Ambiente Humano realizada na cidade de Estocolmo em 1972 é um marco no debate internacional a respeito do papel dos Estados na preservação dos recursos naturais. Ofuscada pela centralidade das questões estratégico-militares enquanto perdurou a Guerra Fria, a questão ambiental ganhou força após a débâcle da União Soviética e tem mobilizado a comunidade internacional nos últimos anos. O Brasil procurou responder às pressões internacionais para que a floresta amazônica seja preservada através de três iniciativas, sendo uma delas de natureza diplomática e as outras duas oriundas do Poder Executivo: o Tratado de Cooperação Amazônica, substituído no final da década de 1990 pela Organização do Tratado de Cooperação Amazônica (OTCA), o Programa Calha Norte e o Sistema de Proteção da Amazônia. 


\subsection{O Tratado de Cooperação Amazônica e a Organização do Tratado de Cooperação Amazônica}

O Tratado de Cooperação Amazônica foi proposto pelo Brasil aos países que compartilham a floresta amazônica em 1977, e celebrado em 03 de agosto de 1978. São signatários do tratado os seguintes países: Bolívia, Brasil, Colômbia, Equador, Guiana, Peru, Suriname e Venezuela. ${ }^{171}$

O TCA foi proposto pelo Brasil como uma resposta às crescentes pressões ecológicas dos países industrializados (Pimenta, 1982). Trata-se de um documento de conteúdo mais político do que técnico ou jurídico uma vez que seu principal objetivo foi de salvaguardar o domínio territorial. O presidente Geisel (1974-1979), no ato de assinatura do Tratado, deixou isso claro quando afirmou que "os países que dividem o território entre si e ninguém mais - têm a exclusiva responsabilidade sobre o seu desenvolvimento". Nas palavras de um analista, criava-se a Amazônia para os amazônidas, e, por isso a Guiana Francesa foi excluída do TCA. (Torrecuso, 2004:56-57).

Pode-se afirmar que os princípios basilares do TCA eram:

1. Responsabilidade exclusiva dos países da região sobre o desenvolvimento e a proteção da Amazônia;

2. Soberania nacional no sentido de enfatizar a absoluta prioridade dos esforços internos que visam 0 desenvolvimento dos territórios amazônicos de cada Estado;

\footnotetext{
${ }^{171}$ Torrecuso lembra que "o Brasil possui um terço de seu território na Bacia Amazônica e $12.967 \mathrm{Km}$ de fronteiras com seus vizinhos, o que corresponde a $63 \%$ de toda a região, sendo seguido por Peru (15,9\%), Bolívia $(11,9)$, Colômbia $(5,8 \%)$, Equador $(2,1 \%)$ e Venezuela $(0,9 \%)$. Ademais, a Bacia Amazônica corresponde à metade do território do Peru e $40 \%$ do equatoriano e, dadas as pequenas dimensões físicas de Guiana e Suriname, os seus respectivos territórios amazônicos tendem a adquirir grande importância para seus governos (Torrecuso, 2004:17)".
} 
3. Cooperação regional como meio de se atingir os primeiros dois objetivos;

4. Equilíbrio e harmonia entre o desenvolvimento e a preservação ambiental;

5. Absoluta igualdade entre as partes contratantes (Pimenta, 1982: 91).

O TCA permaneceu praticamente inativo até o final da década de 1980 quando a crescente sensibilidade internacional a questões ambientais levou à sua revitalização. A fim de tornar a organização mais operativa foi assinada em 1998 uma emenda ao TCA criando a Organização do Tratado de Cooperação Amazônica. A OTCA possui uma secretaria permanente, com sede em Brasília-DF. Este é um importante avanço em relação ao TCA que contava apenas com uma secretaria pro tempore, a qual funcionava rotativamente por dois anos em cada país membro do tratado. A sede permanente deverá tornar a organização mais acessível à participação da sociedade civil e reduzir a descontinuidade entre as políticas de cada secretaria. Ademais, a OTCA possui personalidade jurídica internacional, podendo celebrar tratados com outras organizações internacionais e Estados, o que facilita a obtenção de financiamentos para programas na área ambiental, um dos principais eixos da organização na atualidade (Torrecuso, 2004:09).

\subsection{O Programa Calha Norte}

Criado a partir de estudos do Conselho de Segurança Nacional datados de 1985, o Projeto Calha Norte nasceu sob a influência a Doutrina de Segurança Nacional. O principal objetivo do Calha Norte, explicitado na Exposição de Motivos ํㅜ 18/85, era integrar a região ao norte das calhas dos rios Solimões e Amazonas ao restante do país. E suas linhas de ação imediata eram as seguintes: (a) incremento das relações bilaterais; (b) aumento da presença militar na área; (c) intensificação das campanhas de recuperação dos marcos limítrofes; (d) definição de uma política indigenista 
apropriada à região; (e) ampliação da infra-estrutura viária; (f) aceleração da produção de energia hidrelétrica; (g) interiorização dos pólos de desenvolvimento econômico; (h) ampliação da oferta de recursos sociais básicos (Costa, 1994:06-07).

A natureza e os objetivos do Calha Norte mobilizaram e dividiram os analistas. Os movimentos ambientalistas, os antropólogos e a Igreja Católica, através do seu Conselho Indigenista Missionário, viam o Calha Norte na época de sua implantação como uma tentativa de militarizar a Amazônia (Oliveira, 1994). Shiguenoli Miyamoto voltou suas críticas ao autoritarismo do Estado, responsável pela doutrina de ocupação do território, que estaria na região privilegiando apenas a ótica da segurança (Miyamoto, 1989). A João Roberto Martins Filho preocupava a autonomia com que o Calha Norte foi implementado pelos militares (Martins, 2003).

Para Diniz Costa, o PCN deve ser compreendido como projeto militar e de política indigenista. No âmbito da política doméstica, o Calha Norte reflete uma reação de setores das Forças Armadas às demandas de antropólogos, religiosos e ambientalistas que lutavam pela demarcação das terras indígenas. No plano das percepções geopolíticas, o projeto tinha como objetivo reforçar a presença militar em regiões fronteiriças que apresentavam "problemas de segurança em potencial" na visão dos membros da Secretaria Geral do Conselho de Segurança Nacional tais como: a existência de grupos guerrilheiros na Guiana, Colômbia, Suriname e Bolívia, as disputas territoriais entre Peru e Equador, e a possibilidade de que a Venezuela e a Guiana quisessem rever suas fronteiras com o Brasil, dentre outros fatores. (Costa, 1994).

Bertha K. Becker identifica no Calha Norte o último dos grandes projetos estatais de ocupação do território brasileiro (Becker, 2001). Já Geraldo Cavagnari vê o surgimento do Calha Norte como resposta ao imobilismo do TCA (Cavagnari, 2002).

Em pesquisas mais recentes, Durbens Nascimento (2005) e Marcelle Silva (2004) acompanham a trajetória do Calha Norte desde a sua criação e apontam mudanças significativas na natureza, nos objetivos do PCN e na abrangência do PCN, a começar pelo nome, já que o Calha Norte passou a 
ser considerado um programa governamental prioritário no final dos anos 90, após um período de escassez de recursos. As premissas geopolíticas do Programa também foram matizadas com o tempo e atualmente o principal objetivo do PCN é "aumentar a presença do poder público na região ao norte do rio Solimões/Amazonas, contribuindo para a Defesa Nacional e proporcionando assistência às populações e fixando o homem na região (Silva, 2004:58)". Refletindo as mudanças engendradas em sua natureza e seus objetivos, o PCN teve seu slogan atualizado. O antigo lema Segurança e Desenvolvimento foi substituído por Soberania e Desenvolvimento.

Inicialmente o Programa atendia os estados do Amapá, Amazonas, Pará e Roraima, contribuindo para o incremento da presença estatal nas fronteiras com a Guiana, Guiana Francesa, Suriname, Venezuela e Colômbia. Em 2004, a área de abrangência do Calha Norte foi ampliada e hoje o Programa atende, além dos estados já citados, o Acre e Rondônia. Desta forma, reforçou-se a presença estatal também nas fronteiras com o Peru e a Bolívia. Atualmente, a área coberta pelo PCN corresponde a $25 \%$ do território nacional.

\subsection{O Projeto SIPAM/SIVAM}

Se o Calha Norte gerou muita polêmica em torno de seus objetivos, o SIVAM exaltou os ânimos no país durante seu conturbado processo de licitação, que custou, inclusive, a demissão do então Ministro da Aeronáutica, Mauro José Miranda Gandra. ${ }^{172}$

O Sistema de Proteção da Amazônia e de Vigilância da Amazônia (SIPAM/SIVAM) originou-se na Exposição de Motivos no 194 do Ministério da Aeronáutica, da Secretaria de Assuntos Estratégicos (SAE) e do Ministério da Justiça, ao presidente da República Fernando Collor de Mello (1990), sobre a necessidade de haver um sistema eficiente de produção e processamento de informações qualificadas sobre e para a região

\footnotetext{
${ }^{172}$ A este respeito ver o depoimento de Gandra em: Castro e D’Araujo (2001:293-314).
} 
amazônica. O SIVAM constitui a infra-estrutura de vigilância e análise do SIPAM, cujo objetivo, além da proteção territorial e patrimonial da Amazônia e da defesa da soberania nacional na região, é sistematizar e otimizar as ações dos órgãos governamentais que atuam na região a fim de potencializar as políticas públicas ali estabelecidas. O SIVAM/SIPAM abarca toda a área da Amazônia Legal, e sua estrutura abrange o sensoriamento remoto, a vigilância e controle do tráfego aéreo e de superfície, a monitoração ambiental e meteorológica, a exploração e monitoração de comunicações.

A concepção e o gerenciamento do SIVAM foram atribuídos, por determinação presidencial, à Aeronáutica, dada sua experiência na administração do SISDACTA (Aeronáutica, 1998:73).

Assim como o Calha Norte, o SIVAM também vem chamando a atenção do mundo acadêmico. Lourenção argumenta que o SIVAM é um projeto multiministerial, voltado para a otimização de recursos públicos, que procura responder inteligentemente, mas não de forma subserviente, às ações de novos atores não-governamentais nacionais e estrangeiros que atuam na Amazônia. Ainda de acordo com o autor, o SIVAM acrescenta muitos recursos originais que não foram contemplados no Calha Norte, como o controle do tráfego e a monitoração ambiental (Lourenção, 2003).

$\mathrm{Na}$ mesma linha, Bertha Becker vê a implementação do SIVAM como resposta a um processo de militarização que vem ocorrendo na América Central e na fachada sul-americana do Pacífico. Segundo a autora, após a Guerra Fria verifica-se uma crescente política de transformação dos Andes em "mare nostrum" dos Estados Unidos da América, utilizando a instabilidade política dos países Andinos e a ALCA como contraponto estratégico. Essa política é patente na instalação de bases de operação avançadas na Costa Rica, no Panamá, em Curaçau, no Equador, além do Plano Colômbia (Becker, 2002).

Numa perspectiva diferente, Isabel Rossi afirma que o SIVAM intensifica a dependência tecnológica do país. A instalação dos radares do SIVAM na região fronteiriça da Amazônia brasileira, na opinião de Rossi, evidencia a tendência sub-hegemônica do projeto, em outras palavras, 
contratar a Raytheon (uma empresa norte-americana que fornece equipamentos para o Pentágono) para desenvolver o SIVAM, seria o preço para o Brasil ser aceito pelos Estados Unidos como potência hegemônica na América do Sul (Rossi, 2003).

A implantação do SIVAM foi concluída em julho de 2005 e em abril de 2006 o SIPAM ocupou a última instalação construída pela Comissão para Coordenação do Sistema de Vigilância da Amazônia para abrigá-lo.

\section{A criação do Ministério da Defesa no Brasil e seus impactos sobre a atuação das Forças Armadas na Amazônia ${ }^{173}$}

Os militares brasileiros resistiram à criação de um órgão que substituísse os ministérios militares por várias décadas. Em 1946, a instituição do Estado-Maior das Forças Armadas foi a primeira tentativa de centralizar as atividades de Defesa no país. O novo órgão deveria, em tese, coordenar os assuntos que fossem comuns às três Forças singulares e tentar articulá-las operacionalmente. Contudo, o EMFA nunca foi capaz de desempenhar as tarefas para as quais foi criado. Seu chefe era hierarquicamente inferior aos ministros militares e não tinha poder de comando sobre as Forças Armadas. Portanto, todas as decisões do órgão tinham que ser tomadas por consenso. Em 1967, o primeiro presidente da ditadura militar, Castelo Branco, determinou a elaboração de estudos para criação de um "Ministério das Forças Armadas", mas essa idéia foi abandonada.

Com a volta dos civis ao poder em 1985, o debate acerca da criação do Ministério da Defesa foi retomado durante a elaboração da atual Constituição brasileira, nos anos de 1987 e 1988. Esta tese foi veementemente rejeitada pelos ministros militares que buscaram convencer seus aliados civis no parlamento sobre a inconveniência do órgão. Os militares argumentavam que a proposta de criação do Ministério da Defesa,

173 Discuti com mais vagar algumas idéias apresentadas nesta seção em: Marques (2004b). 
feita por parlamentares de esquerda, era motivada unicamente por um sentimento de revanche contra as Forças Armadas; ou seja, o Ministério da Defesa seria apenas um instrumento para diminuir o poder dos militares na arena política $^{174}$.

O presidente Fernando Collor, eleito em 1989, também aventou a possibilidade de criar o Ministério da Defesa, mas foi dissuadido desta idéia, novamente pelos ministros militares. ${ }^{175}$ Fernando Henrique Cardoso, após vencer as eleições para a presidência da República em 1994, conversou com o então ministro do Exército do governo de Itamar Franco (1992-1994), Zenildo Zoroastro Lucena, sobre sua intenção de criar o Ministério da Defesa. O general Lucena declarou-se favorável ao novo ministério, o que, possivelmente, determinou sua permanência no cargo, e sugeriu a Cardoso que quando fosse convidar os futuros ministros da Marinha, Aeronáutica e o Chefe do EMFA para integrarem o novo governo, falasse claramente sobre essa idéia.

O futuro presidente mostrou-se então mais habilidoso e persistente que seus antecessores no trato de questões delicadas com seus ministros militares. Por exemplo, quando convidou o almirante Mauro César Pereira para o Ministério da Marinha, Fernando Henrique Cardoso, sabendo que enfrentaria uma forte resistência desta Força à sua intenção de criar a nova pasta, declarou que havia votado contra o Ministério da Defesa na Constituinte, mas posteriormente havia sido convencido de suas vantagens. ${ }^{176}$

Outras medidas adotadas por Fernando Henrique Cardoso para facilitar a criação do Ministério da Defesa foram a quebra do rodízio na

\footnotetext{
${ }^{174}$ A respeito da posição oficial das Forças Armadas sobre a criação do Ministério da Defesa quando da sua criação, ver os depoimentos dos então ministros militares a Maria Celina D'Araujo e Celso Castro (2001).

${ }^{175} \mathrm{O}$ general Tinoco, que foi ministro do Exército durante o governo de Fernando Collor de Mello, afirma que seu antecessor, o general Leônidas Pires Gonçalves foi um dos militares que desencorajaram o presidente Collor em relação ao Ministério da Defesa. Castro, Celso; D’Araujo Maria Celina (2001:122).

${ }^{176}$ Castro, Celso; D’Araujo, Maria Celina (2001:278).
} 
chefia do Estado-Maior das Forças Armadas e a sua transformação em Ministério. O EMFA tinha como regra de funcionamento o revezamento entre as três Forças na chefia do órgão. Quando Cardoso assumiu a presidência, seria a vez da Aeronáutica ocupar o posto, mas a Força acabou abrindo mão da vaga em favor do Exército ${ }^{177}$ que ganhou mais um ministro: o general Benedito Onofre Bezerra Leonel. O EMFA recebeu então a determinação presidencial de realizar estudos visando a implantação do novo ministério.

Eliézer Rizzo de Oliveira também chama a atenção para uma decisão do presidente da República que, em sua opinião, também facilitou a criação da pasta da Defesa: a elaboração de um projeto de lei que indeniza as famílias dos mortos desaparecidos políticos durante a ditadura militar. O autor argumenta que "a lei dos desaparecidos", como ficou conhecida, atraiu mais a atenção dos militares do que a criação do Ministério da Defesa, o que acabou contribuindo, indiretamente, para o sucesso estratégia presidencial (Oliveira, 2002:04).

Contando com a aquiescência dos ministros militares, o presidente estabeleceu como meta criar o Ministério da Defesa até o final de seu mandato, em 1998. Cardoso, no entanto, teve que administrar uma série de conflitos entre as três Forças Armadas que dificultaram a consecução de seu projeto.

A concepção do presidente de que o EMFA seria o embrião do futuro Ministério da Defesa, por exemplo, nunca foi aceita pela Marinha ${ }^{178}$, que protagonizou um episódio significativo no processo: a compra de A-4 Skyhawks, aviões de caça norte-americanos projetados para o uso em porta-aviões.

\footnotetext{
177 O brigadeiro Mauro José Miranda Gandra declarou em seu depoimento a Celso Castro e Maria Celina D'Araujo que o presidente Fernando Henrique Cardoso, quando o convidou para ser ministro da Aeronáutica, falou sobre a necessidade da Aeronáutica abrir mão do cargo do EMFA (Castro, Celso e D'Araujo, Maria Celina, 2001:301).

178 Sobre as objeções da Marinha à decisão presidencial de transformar o EMFA em ministério, ver o depoimento de Mauro César Pereira em: Castro; D’Araujo (2001: 288).
} 
Em 1965, a Marinha brasileira perdeu o direito de contar com uma aviação de asas fixas. Essa medida desagradou profundamente 0 oficialato da Marinha, que tentou revertê-la em diversas ocasiões. Quando assumiu o cargo de ministro em 1995, o almirante Mauro César Pereira retomou a discussão com a Aeronáutica sobre a aviação naval.

Após algumas tentativas frustradas de negociar com a Força Aérea a compra de caças para guarnecer o porta-aviões brasileiro, o ministro da Marinha recorreu diretamente ao presidente da República, que autorizou a compra dos A-4 Skyhawk.

A permissão do presidente Fernando Henrique Cardoso para que a Marinha comprasse as aeronaves do Kuwait acirrou os ânimos na Aeronáutica e no Exército. O brigadeiro Lélio Viana Lôbo, que era ministro da Aeronáutica na época do episódio, não esconde suas divergências em relação à opção da Marinha:

Tenho sérias dúvidas se a Marinha fez a melhor opção. Do ponto de vista dos nossos estudos não fez. Talvez tenha feito a opção que the permita atingir a meta de voltar a ter a aviação. Mas dificilmente terá sido a melhor opção (Castro e D’Araujo, 2001:242).

Menos comedido que Lôbo, o general Zenildo Lucena afirma que as aeronaves compradas pela Marinha são inúteis:

Compraram aquelas porcarias para quê? O avião nem serve, nunca vai conseguir decolar. Pode até ser que consiga, mas pousar no aeródromo, não. Todas essas coisas que estou dizendo aqui, falei para o Mauro, para o grupo (Castro e D'Araujo, 2001:222).

A celeuma em torno da aviação naval revelou, de forma contundente, divergências entre as três Forças singulares, deixando claro que essas divergências não se atinham apenas à questão da aviação naval: verificou-se que as Forças Armadas brasileiras trabalhavam com três concepções estratégicas diferentes, nem sempre convergentes.

Concluiu-se então que a criação do Ministério da Defesa seria inviável, caso não se obtivesse um consenso entre as três Forças Armadas sobre os temas concernentes à Defesa Nacional. A promulgação da Política de Defesa Nacional, elaborada sob a coordenação da Câmara de 
Relações Exteriores e Defesa Nacional da Presidência, em novembro de 1996, reflete a preocupação do poder executivo com essa busca de consenso na área militar.

\subsection{A Política de Defesa Nacional}

A Política de Defesa Nacional de 1996 é a primeira publicação governamental a expor as diretrizes do país nas áreas de segurança e defesa $^{179}$. No que tange à orientação estratégica do país, a PDN, voltada para ameaças externas, informa que o país adota uma postura estratégica dissuasória de caráter defensivo, baseada nas seguintes premissas:

1. Fronteiras e limites perfeitamente definidos e reconhecidos internacionalmente;

2. Estreito relacionamento com os países vizinhos e com a comunidade internacional, em geral, baseado na confiança e no respeito mútuos;

3. Rejeição à guerra de conquista; e

4. Busca de solução pacífica de controvérsias, com o uso da força somente como recurso de autofedefesa.

Quanto ao espaço geoestratégico de atuação das Forças Armadas, a Política de Defesa Nacional define que:

Para o Brasil, país de diferentes regiões internas e de diversificado perfil, ao mesmo tempo amazônico, atlântico, platino e do Cone Sul, a concepção do espaço regional extrapola a massa continental sulamericana e inclui, também o Atlântico Sul (Brasil, 1996:05).

No que diz respeito à Amazônia, a PDN em sua análise do panorama regional revela a preocupação do governo com as zonas de instabilidade existentes na América do Sul e a "ação de bandos armados que atuam em países vizinhos, nos lindes da Amazônia brasileira (Brasil,

${ }^{179}$ Sobre os significados da promulgação da Política de Defesa Nacional brasileira ver: Oliveira (1998). 
1996:06)" e determina que a proteção da Amazônia dar-se-á com o apoio de toda a sociedade e com a valorização da presença militar. A PDN determina ainda a priorização de ações para desenvolver e vivificar a faixa de fronteira, em especial nas regiões norte e centro-oeste (Brasil,1996:10).

Em 2005, a PDN foi atualizada. O novo documento, voltado preponderantemente, para ameaças externas, reafirma a postura estratégica dissuasória do país e acrescenta às quatro premissas já citadas a: (1) valorização dos foros internacionais; (2) existência de forças armadas modernas, balanceadas e aprestadas; e a (3) capacidade de mobilização nacional. A nova PDN reafirma também o espaço geoestratégico no qual as Forças Armadas brasileiras devem atuar.

No tocante à percepção do ambiente internacional, a nova PDN faz referências a um tema recorrente no discurso militar sobre a Amazônia, a cobiça internacional, quando afirma que:

Neste século, poderão ser intensificadas disputas por áreas marítimas, pelo domínio aeroespacial e por fontes de água doce e de energia, cada vez mais escassas. Tais questões poderão levar a ingerências em assuntos internos, configurando quadros de conflito (Brasil, 2005c).

E também quando diz explicitamente que a Amazônia brasileira "com seu grande potencial de riquezas minerais e de biodiversidade, é foco de atenção internacional (Brasil, 2005c)".

No âmbito regional, a nova PDN reafirma a preocupação do país com a existência de zonas de instabilidades e ilícitos transnacionais na América do Sul e o possível transbordamento destes para o território nacional. E determina que para proteger a Amazônia é necessário: (1) aumentar a presença militar; (2) desenvolver e vivificar a faixa de fronteira; (3) atuar para a manutenção de clima de paz e cooperação nas áreas de fronteira; e (4) intensificar o intercâmbio com as Forças Armadas da América do Sul (Brasil, 2005c).

Vejamos agora como a criação do Ministério da Defesa incidiu na preparação militar para a defesa da Amazônia. 


\subsection{A estrutura organizacional e as funções do Ministério da Defesa}

O Ministério da Defesa foi criado em junho de 1999, no segundo mandato do presidente Fernando Henrique Cardoso, através da Medida Provisória 1.799-6 (Brasil, 1999b). Seu organograma atual tem a seguinte configuração: o ministro conta com órgãos de assistência direta e imediata (Gabinete do Ministro e Consultoria Jurídica) e de assessoramento (Conselho Militar de Defesa e Estado-Maior de Defesa). O ministério conta também com quatro Secretarias (Política, Estratégica e Assuntos Internacionais; Logística e Mobilização; Organização Institucional e Estudos e Cooperação) e diversos órgãos de estudos, assistência e apoio subordinados às Secretarias Especiais e ao Gabinete do Ministro (Escola Superior de Guerra, Hospital das Forças Armadas, Ordinariado Militar, Representação Brasileira na Junta Interamericana de Defesa e Centro de Catalogação das Forças Armadas). Ademais, fazem parte da estrutura organizacional do ministério um órgão setorial (Secretaria de Controle Interno), um órgão colegiado (Conselho de Aviação Civil) e uma entidade vinculada (Empresa Brasileira de Infra-Estrutura Aeroportuária).

As Forças Armadas, através dos Comandos da Marinha, Exército e Aeronáutica, estão subordinadas ao ministro da Defesa, contrariando as propostas militares que equiparavam os três comandantes militares ao ministro da Defesa. Aos comandantes militares, no entanto, foi assegurada a precedência hierárquica sobre os demais oficiais-generais das três Forças Armadas e o direito a julgamento em foro especial (Brasil, 1999c; Brasil 1999d).

Os assuntos de competência do Ministério da Defesa são: I) política de defesa nacional; II) política e estratégia militares; III) doutrina e planejamento de emprego das Forças Armadas; IV) projetos especiais de interesse da defesa nacional; V) inteligência estratégica e operacional no interesse da defesa; VI) operações militares das Forças Armadas; VII) relacionamento internacional das Forças Armadas; VIII) orçamento de defesa; (X) legislação militar; X) política de mobilização nacional; XI) política de ciência e tecnologia nas Forças Armadas; XII) política de comunicação 
social nas Forças Armadas; XIII) política de remuneração dos militares e pensionistas; XIV) política nacional de exportação de material de emprego militar, fomento às atividades de pesquisa e desenvolvimento e de produção e exportação em áreas de interesse da defesa e controle da exportação de material bélico de natureza convencional; XV) atuação das Forças Armadas, quando couber, na garantia da lei e da ordem, visando à preservação da ordem pública e da incolumidade das pessoas e do patrimônio, bem como sua cooperação com o desenvolvimento nacional e a defesa civil e ao apoio ao combate a delitos transfronteiriços ou ambientais; XVI) logística militar; XVII) serviço militar; XVIII) assistência à saúde, social e religiosa das Forças Armadas; XIX) constituição, organização, efetivos, adestramento e aprestamento das forças navais, terrestres e aéreas; $X X)$ política marítima nacional; $X X I$ ) segurança da navegação aérea e do tráfego aquaviário e salvaguarda da vida humana no mar; XXII) política aeronáutica nacional e atuação na política nacional de desenvolvimento das atividades aeroespaciais; XXIII) infra-estrutura aeroespacial, aeronáutica e aeroportuária (Brasil, 2003c).

Se a criação do Ministério da Defesa no Brasil teve com principal objetivo racionalizar o preparo e o emprego das Forças Armadas brasileiras, através de uma maior integração estratégica e operacional das Forças singulares, o funcionamento do novo ministério até o momento permite afirmar que foram feitos alguns pequenos avanços no âmbito da integração operacional entre as Forças Armadas, que se expressam na realização de exercícios e operações combinadas.

A criação do Estado-Maior de Defesa (EMD) foi fundamental para estes avanços. O órgão tem como principal missão planejar e discutir diretrizes e documentação para o emprego das Forças Armadas de maneira combinada. O Chefe do Estado-Maior de Defesa é um Oficial General da ativa, do último posto. A Chefia do órgão é ocupada em sistema rodízio entre as Forças Armadas, como no antigo EMFA (Taveira, 1999). De acordo com Alexandre Fuccille, o Estado-Maior de Defesa nos últimos anos empreendeu um esforço significativo no sentido de elaborar um conjunto de publicações que começasse a padronizar e normatizar os 
temas ligados à Defesa para as três Forças Armadas (Fuccille, 2006:200). A publicação da Doutrina Militar de Defesa no início de 2007 é um exemplo das publicações produzidas no âmbito do Estado-Maior da Defesa.

Comparando a estrutura e as funções do Estado-Maior de Defesa brasileiro com o de outros países, Fuccille conclui que o raio de atuação do EMD brasileiro é bastante limitado (Fuccille, 2006:2003). O papel do EMD na realização de operações militares na Amazônia é representativo de suas limitações.

Em maio de 2002 foi realizada a primeira operação combinada das Forças Armadas brasileiras após a criação do Ministério da Defesa: a Operação Tapuru. Essa operação foi ambientada na Amazônia, mais precisamente na região que abrange as cidades de Tefé, Tabatinga e São Gabriel da Cachoeira, na zona fronteiriça com a Colômbia. A escolha do local para a realização da operação Tapuru é significativa, se lembrarmos a preocupação dos militares brasileiros com a presença norte-americana na Colômbia.

A Tapuru teve como objetivo avaliar os procedimentos de comando e controle, apoio logístico e de comunicações, próprios para o emprego combinado das três Forças Armadas. O Comando da operação coube ao Comandante Militar da Amazônia, general Valdésio Guilherme Figueiredo. Ao Estado-Maior de Defesa coube acompanhar o desenrolar da operação verificando o cumprimento das doutrinas afetas aos Comandos Combinados, além de supervisionar e orientar as ações de Comando e Controle no nível político-estratégico (Exército Brasileiro, 2004a).

Nas operações que se seguiram à Tapuru, como a Operação Timbó $^{180}$ e a Operação Tucunaré ${ }^{181}$, o EMD desempenhou o mesmo papel secundário, ficando o comando das operações com o Exército. As operações combinadas realizadas na Amazônia também obedecem a um

${ }^{180}$ A Operação Timbó é realizada anualmente desde 2003. Sua área de atuação abrange 416 mil quilômetros quadrados na fronteira com Peru, Colômbia e Venezuela (Exército Brasileiro, 2007j).

${ }^{181}$ A Operação Tucunaré é realizada desde 2004 e sua área de atuação inclui os estados do Pará e Amapá (Ministério da Defesa, 2007l). 
padrão semelhante às que são realizadas pelo Exército. A Força Aérea e a Marinha, de uma maneira geral, atuam como forças de apoio e as ações cívico-sociais ocupam um papel de destaque no dia-a-dia das tropas.

Se do ponto de vista operacional os avanços do Ministério da Defesa são tímidos, no âmbito político os avanços são um pouco mais significativos. A série de acordos e memorandos de entendimentos na área de segurança e defesa assinada com países amazônicos, exposta no capítulo anterior, está contribuindo para a criação de algumas medidas de confiança mútuas essenciais para o aprofundamento da cooperação militar na América do Sul.

\section{Poder Legislativo e Presença Militar na Amazônia ${ }^{182}$}

É ponto pacífico na bibliografia sobre as relações civis-militares no Brasil o escasso controle parlamentar sobre as políticas públicas voltadas para as áreas de segurança e defesa. Uma combinação entre a fragilidade programática dos partidos políticos brasileiros e o baixo "retorno eleitoral" de temas como Relações Exteriores e Defesa Nacional explicaria a ineficiência do Congresso no tratamento desses assuntos.

Eliézer Rizzo de Oliveira chama a atenção para a improvisação com que foram tratados os assuntos relacionados à Defesa Nacional na Subcomissão de Defesa do Estado, da Sociedade e de suas Instituições durante o processo de elaboração da Constituição de 1988. Na opinião do autor, a patente falta de conhecimento da maioria dos parlamentares a respeito dos temas sobre os quais estavam legislando era fruto da fragilidade programática dos partidos políticos brasileiros que, à época, não elaboravam nenhum tipo de reflexão consistente sobre a temática militar (Oliveira, 1994). Em um estudo mais recente, Oliveira reafirma sua análise anterior, argumentando que o minimalismo continua sendo a marca legislativa no que se refere à Defesa Nacional, pois as iniciativas dos

182 Uma versão preliminar desta seção está disponível em: Marques (2006). 
legisladores sobre esse assunto são tímidas e insuficientes (Oliveira, 2005:49).

Na visão de João Roberto Martins Filho, o legislativo brasileiro tem se mostrado incapaz de interferências significativas nas questões militares. Analisando as relações civis-militares durante o governo de Fernando Henrique Cardoso, Martins afirma que, em todos os episódios de reafirmação da autonomia militar, a reação do Poder Legislativo foi tardia e desarticulada (Martins, 2004).

Para Samuel Alves Soares, as razões pelas quais o legislativo não tem sido capaz de apresentar políticas consistentes para o setor de Defesa são variadas e dizem respeito à ausência de um debate articulado, à falta de estudos legislativos sobre o tema e ao pouco prestígio conferido aos parlamentares que pertencem às Comissões de Defesa. Soares também atenta para o fato de que o desinteresse do parlamento sobre as questões militares reflete o desinteresse da sociedade civil sobre o tema (Soares, 2004:93). Ainda sobre esse tópico, Maria Helena de Castro Santos, referindo-se às eleições de 2002, constatou que nenhum programa dos candidatos a uma vaga no parlamento incluía temas militares (Santos, 2004:121).

Daniel Flemes toca em um ponto crucial para a análise do funcionamento das Comissões de Defesa no Brasil: a baixa qualidade das informações disponíveis para os seus componentes. Em depoimento ao autor, o general da reserva Stelson Ponce, consultor parlamentar do Senado Federal, declarou que no concurso para a consultoria legislativa, as questões militares e de defesa não são, de forma alguma, levadas em consideração. Na falta de uma assessoria parlamentar qualificada no Congresso, os congressistas costumam recorrem às assessorias parlamentares das Forças Armadas para obter informações acerca de temas concernentes à segurança e defesa. Flemes ressalta que esse procedimento, visto com naturalidade pelos parlamentares brasileiros, compromete a independência e a neutralidade das informações que lhes são fornecidas (Flemes, 2004:09-10). 
Jorge Zaverucha atribui a inoperância do Legislativo no tocante à política de Defesa Nacional às limitações impostas pelos militares através da ameaça explícita, ou não, de golpe à ação dos políticos civis. Para o autor, os militares brasileiros detêm uma série de prerrogativas que thes permite influenciar significativamente a tomada de decisões políticas. Em relação ao escasso controle orçamentário sobre as Forças Armadas exercido pelo Poder Legislativo, Zaverucha argumenta que a participação do Congresso Nacional nessa seara era mínima antes da criação do Ministério da Defesa, e assim continua sendo (Zaverucha, 2003:11-12).

A próxima seção focará a discussão acerca do papel dos militares na Amazônia no Congresso Nacional e suas implicações para a formulação de uma política de Defesa para a região.

\subsection{A defesa da Amazônia nos documentos partidários}

O tratamento dado à temática militar nos programas dos partidos políticos brasileiros é bastante heterogêneo. Esta heterogeneidade, todavia, não está relacionada ao perfil ideológico dos partidos políticos, mas à profundidade com que as questões de segurança internacional e defesa nacional são discutidas nos documentos partidários ${ }^{183}$.

O Partido Socialista Brasileiro (PSB) e o Democratas (DEM) ${ }^{184}$ apenas reproduzem em seus programas partidários alguns postulados do Itamaraty tais como a luta pelo desarmamento internacional, a eliminação dos arsenais nucleares, o respeito à autodeterminação dos povos e a não ingerência em assuntos internos de outros países (Partido Socialista Brasileiro, 2007; Democratas, 2007).

O Partido da Social Democracia Brasileira (PSDB) e o Partido

\footnotetext{
${ }^{183}$ Não incluí nesta discussão o programa do Partido dos Trabalhadores, que foi elaborado em 1980 e ainda não foi atualizado pela legenda.

${ }^{184}$ DEM é a sigla adotada em 2007 pelo Partido da Frente Liberal (PFL).
} 
Popular Socialista (PPS) ${ }^{185}$ também não se referem textualmente ao papel das Forças Armadas em documentos oficiais recentes, limitando-se a expor algumas idéias sobre como o Brasil deve se posicionar frente às mudanças na ordem internacional. O PSDB e o PPS reconhecem a superioridade militar dos Estados Unidos, mas ressaltam que o Brasil não deve se alinhar automaticamente a nenhum bloco econômico e militar. Os partidos também pleiteiam o fortalecimento da Organização das Nações Unidas (ONU) e a reformulação do seu Conselho de Segurança. No âmbito regional, o PSDB e o PPS defendem o fortalecimento e a ampliação do Mercosul através da adesão de outros países da América do Sul (Partido da Social Democracia Brasileira, 2005; Partido Popular Socialista, 2005).

Alguns partidos como o Partido Progressista (PP), O Partido Trabalhista Brasileiro (PTB), o Partido da República (PR) ${ }^{186}$, e o Partido Comunista do Brasil (PC do B) e o Partido Socialismo e Liberdade (PSOL) abordam tangencialmente as questões militares em seus programas.

O PTB, "sublinha a necessidade de ocupação ordenada das regiões de fronteiras e $\mathrm{o}$ aporte de recursos necessários para controle aéreo, malha viária e comunicações em geral, como forma de proteger a integridade do território nacional e desenvolver estas áreas" (Partido Trabalhista Brasileiro, 1999).

O PP diz apenas que as Forças Armadas são instituições nacionais, permanentes e regulares, organizadas com base na hierarquia e na disciplina, sob a autoridade suprema do Presidente da República, para o

185 O PPS foi fundado em 1992 por lideranças históricas do antigo Partido Comunista Brasileiro. A sigla PCB ainda existe, mas o partido não possui representantes no Congresso Nacional.

${ }^{186}$ O Partido da República foi criado em 2007 através da fusão do Partido Liberal com o Partido de Reedificação da Ordem Nacional (PRONA). O último tinha propostas bem claras, e um tanto polêmicas, acerca das prioridades estratégicas do país e do papel da Forças Armadas, mas estas posições não foram encampadas pelo PR. Além disso, as propostas do PRONA refletiam, em grande medida, as idéias do fundador do partido, deputado Enéias Carneiro, falecido em maio de 2007. 
cabal cumprimento da missão de defenderem a soberania nacional e garantirem as instituições democráticas. ${ }^{187}$

O PR afirma que as Forças Armadas devem subordinar-se ao poder civil. Devem igualmente ser permanentemente adestradas e modernizadas, em seu equipamento e em sua organização. Aos militares também deve ser assegurado direito de votar e ser votado (Partido da República, 2007).

O PC do B reivindica a criação de Comitês Populares de Defesa Civil, deixando transparecer a idéia, tão cara a uma parcela mais ortodoxa da esquerda brasileira e às próprias Forças Armadas, de que os militares são o "povo em armas" (Partido Comunista do Brasil, 2005). O PSOL, aliás, é mais explícito neste sentido quando defende que é "fundamental a democratização (...) do Exército, com o direito a livre organização política das tropas, com direito das tropas elegerem seus próprios comandantes; com direito de promoção, sem limites para a baixa oficialidade (Partido Socialismo e Liberdade, 2007)".

Já o Partido do Movimento Democrático Brasileiro (PMDB), o Partido Democrático Trabalhista (PDT), e o Partido Verde (PV) apontam de forma mais clara qual a posição do partido acerca das prioridades estratégicas do país e do papel das Forças Armadas.

O PV tem um programa bastante detalhado acerca do papel que deve ser desempenhado pelas Forças Armadas no país e se distingue dos demais partidos por ser o único a refutar a participação militar no desenvolvimento tecnológico do país. No âmbito das relações civismilitares, o PV defende a subordinação das Forças Armadas ao poder civil; o fim do julgamento militar para crimes civis; e o direito ao voto dos soldados e marinheiros. No âmbito da Defesa Nacional, o partido defende uma nova doutrina de Defesa Nacional centrada na defesa do ecossistema; o fim do serviço militar obrigatório e a profissionalização do contingente;

${ }^{187}$ O PP é a nova sigla do antigo Partido Democrático Social (PDS). Na década de 1990, a agremiação adotou o nome de Partido Progressista Reformador (PPR) e Partido Progressista Brasileiro. Atualmente, se chama Partido Progressista. Apesar da mudança de sigla, O PP incorporou o programa partidário do antigo PPB. A este respeito ver: PARTIDO PROGRESSISTA BRASILEIRO (1999). 
atribui às Forças Armadas a missão de patrulhamento das fronteiras no sentido de garantir o monopólio dos armamentos de guerra; e defende a formação de batalhões florestais especializados no patrulhamento e na educação ambiental. O programa salienta que grandes projetos de defesa das fronteiras amazônicas devem ser compatíveis com preservação da floresta e das nações indígenas da região. Por isso, o PV defende a supressão das disposições do Programa Calha Norte no tocante à transformação de comunidades indígenas em colônias agrícolas e do recrutamento de índios para o serviço militar.

Contudo, o ex-presidente do PV, Alfredo Sirkis, esclarece que as críticas do partido se restringem ao modo como a presença militar na Amazônia vem sendo conduzida. Feita esta ressalva, o PV reconhece a necessidade de um dispositivo militar na região, sobretudo nas fronteiras com o Peru, Venezuela e Colômbia (Sirkis, 1999).

Além disso, o PV defende o cancelamento do Acordo Nuclear BrasilAlemanha; a passagem da usina de enriquecimento de urânio de Aramar para controle civil; e rejeita a construção do submarino nuclear. No âmbito da segurança internacional, o PV acredita que o Brasil deve lutar por uma vaga no Conselho de Segurança da ONU; e é favorável à ratificação de tratados internacionais que rechacem a proliferação nuclear (Partido Verde, 2005).

O programa partidário do PDT enfatiza a contribuição das Forças Armadas brasileiras para o desenvolvimento tecnológico do país e ressalta o papel de assistência social que estas desempenham junto às populações desassistidas pelo poder público, afirmando que os militares são os agentes do processo civilizatório nas regiões mais remotas do país. $\mathrm{O}$ partido acredita que a importância das Forças Armadas nos assuntos internos do país decorre, em parte, da incapacidade das elites políticas de formularem um projeto nacional consistente no qual elas tenham papel claramente definido.

Sobre as questões de segurança e defesa na Amazônia, o PDT entende que as fronteiras da região amazônica são extremamente vulneráveis, mal protegidas e seus marcos demarcatórios vulneráveis e 
correndo o risco de se tornarem enclaves e objeto de invasões de fronteiras, de área de contrabando e narcotráfico. O partido não aceita que os países desenvolvidos assumam propostas de internacionalização da região a pretexto de combate à violação dos direitos humanos. O PDT propõe que, através da ação coordenada pelo Estado brasileiro, o poder público federal e estadual, as Forças Armadas e a sociedade civil atuem de forma a consolidar a integridade da região amazônica. O PDT defende o reaparelhamento tecnológico das Forças Armadas para o sistema de vigilância da Amazônia, incluindo rede de radares e de outros tipos de sensores, de sistema de transmissão e comunicação de dados por satélites (Partido Democrático Trabalhista, 2005).

O PDT identifica o Atlântico Sul como espaço de atuação geoestratégico do país, ressalta a necessidade de se aumentar os recursos destinados à proteção do mar territorial e, finalmente, defende a continuidade do serviço militar obrigatório. Em relação aos temas concernentes à segurança internacional, o PDT se diz contrário aos "projetos internacionais, patrocinados pelos países ricos, que pretendem transformar as Forças Armadas dos países subdesenvolvidos em Guardas Nacionais ou forças policiais auxiliares condenadas ou supervisionadas por organismos internacionais e supranacionais" (Partido Democrático Trabalhista, 2005).

O programa partidário do PMDB reconhece as Forças Armadas como instrumentos indispensáveis de afirmação da independência e da integridade nacional e que, portanto, fazem parte do projeto brasileiro de democracia e de desenvolvimento autônomo e sustentado. Para o PMDB, a defesa do Estado pressupõe a união de povo, governo e instituições nacionais. Por conseguinte, o partido espera das Forças Armadas: identificação com os objetivos e valores da sociedade, credibilidade bélica, adequada formação profissional, capacidade operacional para atuar em todo espaço nacional, e participação no esforço de desenvolvimento tecnológico.

Assim como o PDT, o PMDB reconhece o Atlântico Sul como espaço geoestratégico prioritário do país, mas não descarta uma ação do Brasil 
fora desse espaço "quando forem suscitadas questões que nos afetem de forma vital". O partido também garante que em seu governo as Forças Armadas nunca receberão recursos orçamentários inferiores a 1\% do PIB brasileiro (Partido do Movimento Democrático Brasileiro).

Vale notar que os programas partidários nos quais foram apresentadas, de forma mais detalhada, algumas reflexões sobre o papel das Forças Armadas, a necessidade da presença militar na Amazônia é enfatizada. Esta tendência também pode ser constatada nos programas de governo dos candidatos à presidência da República em 2002.

Os quatros principais candidatos à presidência da República no ano de 2002 apresentaram propostas para a área de Defesa Nacional, um fato até então inédito na história política nacional ${ }^{188}$. $O$ tratamento dado às questões castrenses nos programas de governo ainda está longe do desejável, mas vamos nos deter às posições dos partidos a respeito do papel que deve ser desempenhado pelas Forças Armadas na região amazônica e aos comentários concernentes à parca atuação das Comissões de Defesa no Congresso Nacional.

O item do programa de governo da coligação Grande Aliança (PSDB/PMDB), do candidato José Serra, que trata das questões militares tinha o sugestivo título de Fronteiras Protegidas. Neste tópico, é defendida a tese de que, em razão do agravamento da guerra civil colombiana, o governo deve "enfatizar a importância da estratégia de presença na Amazônia" e dar apoio à continuidade das atividades subsidiárias das Forças Armadas na região. A despeito do Calha Norte e do SIVAM serem projetos interministeriais, no texto em questão eles são citados como

${ }^{188} \mathrm{O}$ primeiro partido a tratar de questões referentes à Defesa Nacional em seu programa de governo foi o Partido dos Trabalhadores (PT), em 1994. Alguns artigos publicados na revista Teoria e Debate, editada pela Fundação Perseu Abramo, ligada ao partido, contemplam o debate travado no interior do partido acerca do papel a ser desempenhado pelas Forças Armadas na Amazônia (Cavagnari, 1994; Queiroz, 1994; e Pinto, 1994). No programa de governo prevaleceu a tese defendida pelo coronel Cavagnari. Nas eleições de 1998, o então candidato à reeleição pelo Partido da Social Democracia Brasileira (PSDB), Fernando Henrique Cardoso também incorporou algumas notas sobre a temática em seu programa de governo (Partido da Social Democracia Brasileira, 2005b). 
"programas prioritários das três Forças singulares". O documento também aborda um tema bastante discutido pela bibliografia que analisa 0 desempenho do parlamento no tocante às questões de Defesa Nacional: sua ineficiência nesse setor. Para reverter esta situação, a coligação propõe estimular "o legislativo para que se aprofunde no conhecimento e acompanhamento das decisões sobre os temas específicos dessa área" (Coligação Grande Aliança, 2005).

O debate sobre a atuação do legislativo, bem como a preocupação com os desdobramentos da crise colombiana, estão presentes no programa de governo do candidato Anthony Garotinho que concorreu pelo PSB. De acordo com esse documento, as Comissões de Relações Exteriores e de Defesa Nacional da Câmara e do Senado não cumprem "adequadamente seu papel. Ou não há discussão ou, se ela ocorre, é insuficiente e sem densidade". Além disso, o Congresso Nacional, na opinião do PSB, não cumpriria sua função de mediação, definida como a capacidade de "receber as demandas da corporação militar e de debatê-las, tanto com as Forças Armadas quanto com diferentes instâncias do Executivo" (Partido Socialista Brasileiro, 2005). Em relação à presença das Forças Armadas na Amazônia, o PSB considera o número de unidades militares existentes na região insuficientes para controlar a fronteira e pede a "aceleração" do Projeto Calha Norte, em razão dos rumores sobre a internacionalização da Amazônia (Partido Socialista Brasileiro, 2002).

O PSB entende que o poder e a autoridade do Estado brasileiro na Amazônia são precários. Neste sentido, os militares garantiriam a ocupação territorial, a presença e a autoridade do Estado na região. Ainda segundo o documento em questão, as Forças Armadas devem "coibir o processo que está ocorrendo em diferentes áreas do território amazônico implicando em pilhagem sistemática de riquezas, pela ação descontrolada de grupos nacionais e estrangeiros". Finalmente, a possibilidade de internacionalização da crise colombiana em decorrência do Plano Colômbia, preocupa a cúpula do PSB (Partido Socialista Brasileiro, 2005). 
Nos programas de governo do candidato Ciro Gomes da Frente Trabalhista (PTB/PDT/PPS) ${ }^{189}$ e da coligação Lula Presidente (PT/PCdoB/PL/PMN ${ }^{190 / P C B) ~ a ~ d e f e s a ~ d a ~ A m a z o ̂ n i a ~ t a m b e ́ m ~ a p a r e c e ~ c o m o ~}$ prioridade nos espaços destinados à apresentação de propostas para o setor de Defesa Nacional (Frente Trabalhista, 2005; Coligação Lula Presidente, 2005).

Nas últimas eleições presidenciais, os dois candidatos que disputam o segundo turno apresentaram suas propostas para a área de Defesa Nacional. O programa do candidato derrotado Geraldo Alckmin, da coligação Por um Brasil Decente (PSDB-PFL), defende a necessidade do Brasil contar com um "poder militar moderno dissuasor, com capacidade de mobilização e de resposta eficaz a eventuais ameaças", o documento também enfatiza que "o foco hoje é a Amazônia, onde podem ocorrer ameaças irregulares, desde o extravasamento da guerrilha de países vizinhos até a criminalidade organizada (Coligação Por um Brasil Decente, 2006:153)".

Para defender militarmente a área o programa do PSDB-PFL propõe: (1) controlar as fronteiras permeáveis a penetrações de forças irregulares e às atividades ilícitas transfronteiriças, como contrabando de armas e drogas; (2) consolidar a rede de unidades de fronteira na Amazônia e completar a transferência de unidades para a região, conferindo às Forças Armadas preparo e equipamento adequados para cumprir missões de qualquer natureza; e (3) avaliar a criação de um comando combinado permanente na Amazônia Ocidental, capaz de utilizar todo o potencial do SIVAM para sensoriamento, comando e controle, comunicações, inteligência, controle da faixa de fronteira e do espaço aéreo (Coligação Por um Brasil Decente, 2006:154-155).

Já o programa de governo do presidente reeleito Luís Inácio Lula da Silva não faz nenhuma referência à postura estratégica que deve ser adotada pelo país. Limita-se a informar que pretende concluir o processo

\footnotetext{
${ }^{189}$ Frente Trabalhista (2002).

${ }^{190}$ Partido da Mobilização Nacional.
} 
de institucionalização do Ministério da Defesa e, no que concerne à Amazônia, que pretende "dar continuidade às ações de vigilância e proteção do território nacional, sobretudo de regiões de fronteira, por meio de instrumentos como o SIVAM-SIPAM e outros mecanismos de controle do crime organizado e de grupos que atentam contra a integridade do território nacional (Coligação A Força do Povo, 2006)".

Entre os fatores que contribuíram para a atenção dada às questões de Defesa Nacional nos programas de governo a partir das eleições de 2002, a criação do Ministério da Defesa em 1999 certamente é o mais importante. No entanto, outra questão pode ter influenciado o tratamento dado à temática militar nos documentos citados: a criação das Comissões de Relações Exteriores e Defesa Nacional. Sobre esta possibilidade, vale lembrar que no período em que esses programas de governo foram redigidos, as Comissões de Relações Exteriores e Defesa Nacional já funcionavam no parlamento há quase uma década.

\subsection{O debate sobre a Amazônia nas Comissões de Relações Exteriores e Defesa Nacional}

As Comissões Permanente de Relações Exteriores e Defesa Nacional da Câmara dos Deputados foi criada em 1996 pela junção de duas comissões que funcionavam anteriormente na Câmara: a Comissão de Relações Exteriores e a Comissão de Defesa Nacional ${ }^{191}$. Neste mesmo período, o então presidente da República, Fernando Henrique Cardoso, aproveitou a reforma do regimento interno do Senado para criar uma Comissão nos mesmos moldes no Senado Federal (Oliveira, 2005:432).

A CREDN tem algumas particularidades. Primeiramente, os temas tratados pela Comissão de Relações Exteriores e Defesa Nacional em sua maioria não são prioritários para o Executivo, o que possivelmente explica o baixo grau de partidarização da comissão.

${ }^{191}$ A antiga Comissão de Defesa Nacional se chamou durante décadas Comissão de Segurança Nacional. 
Contudo, há evidências de que quando algum interesse fundamental do Executivo está em jogo, como no caso da criação do Ministério da Defesa, por exemplo, a base governista é pressionada a votar de acordo com a determinação dos líderes partidários. ${ }^{192}$

Além disso, cabe lembrar que as comissões são destinadas aos partidos políticos de acordo com a força de suas bancadas (Figueiredo e Limongi, 1999). Portanto, é bastante significativo que a CREDN tenha sido presidida por parlamentares do bloco de oposição na época da promulgação da Política de Defesa Nacional e da criação da Agência Brasileira de Inteligência, os dois principais projetos que foram votados nesta comissão durante 0 primeiro mandato de Fernando Henrique Cardoso.

A Comissão de Relações Exteriores e Defesa Nacional também conta com um núcleo estável de parlamentares que atuam no órgão ${ }^{193}$. A estabilidade na composição das Comissões de Defesa é um dado relevante, pois é sabido que há um elevado nível de rotatividade nas comissões brasileiras. De maneira geral, é prerrogativa dos líderes partidários nomear, assim como substituir, a qualquer momento, os membros das comissões, uma vez que não há restrições quanto ao tempo de permanência dos deputados desses órgãos. Por isso, apesar da existência de um núcleo estável de parlamentares em cada comissão permanente, conforme apontam Carlos Pereira e Bernardo Mueller (2000),

192 O deputado Pannunzio (1999) declarou que durante o processo de criação do Ministério da Defesa, os parlamentares do PSDB receberam uma recomendação partidária para aprovarem na CREDN o projeto que havia sido enviado pelo executivo.

193 Tomando como referência os anos legislativos de 1999 e 2005, permanecem atuando na CREDN da Câmara: os deputados Fernando Gabeira (PV/RJ), Jair Bolsonaro (PP/RJ) e João Hermann Neto (PDT/SP), os deputados Luiz Carlos Hauly (PSDB/PR), Antônio Carlos Pannuzio (PSDB/SP) e José Guimarães Neiva Moreira (PMDB/MA) que a presidiram em legislaturas anteriores, e os deputados Paulo Delgado (PT/MG) e Maninha (PT/DF) que já ocuparam a primeira vice-presidência. Alguns deputados que presidiram a CREDN a partir do ano 2000, tais como Zulaiê Cobra (PSDB/SP) e Carlos Melles (PFL/MG), continuaram participando da comissão após terminarem seus mandatos. A Comissão de Relações Exteriores e Defesa Nacional do Senado Federal também apresentou uma composição estável no último qüinqüênio. 
a composição total das comissões tende a variar freqüentemente, inclusive entre uma reunião e a seguinte, quando os líderes partidários desejam influir no resultado da votação de determinadas propostas.

No caso específico das Comissões de Defesa brasileiras, é possível afirmar que a estabilidade de suas composições tem sido acompanhada de um elevado grau de consenso entre os congressistas que as compõem acerca dos temas que lá são discutidos.

Entre os temas em torno dos quais há um grande consenso nas Comissões de Defesa brasileiras destaca-se a necessidade de se aumentar a presença militar na Amazônia, principalmente, através da revitalização do Projeto Calha Norte (PCN).

O PCN, que há alguns anos recebeu o status de programa governamental, foi praticamente paralisado durante os governos de Fernando Collor e Itamar Franco, situação que se repetiu durante 0 primeiro governo de Fernando Henrique Cardoso, situação que foi parcialmente revertida somente em 1999 em função do empenho da senadora Marluce Pinto (PMDB/RR). A senadora, atualmente sem mandado no Congresso Nacional, presidiu no início da década de 1990 uma Comissão Mista destinada a reavaliar o Calha Norte e, desde então, tornou-se uma defensora do projeto no Senado Federal juntamente com outros representantes da bancada amazônica. Em um discurso proferido em 1999, a senadora aborda três temas que se entrelaçam na narrativa parlamentar sobre a importância da presença militar na Amazônia: a demarcação das terras indígenas, o risco de internacionalização da Amazônia e o Calha Norte. A senadora Marluce Pinto inicia sua fala lamentando a morte de um ex-diretor da FUNAI e no trecho que será transcrito abaixo tem como interlocutores os senadores Romeu Tuma (PFL/SP) e Ernades Amorim (PPB/RO):

(...) Muito se fez, mas muito ainda precisa ser feito para satisfazer questões seríssimas que envolvem interesses de índios e não-índios, uma realidade nacional que vem à tona sempre acompanhada de tensão e angústia. Ainda está na fervura e traz intranqüilidade a demarcação da área Raposa Serra do Sol, em Roraima. (...) Agrava a 
situação o fato de que em meio à reserva pretendida estão situadas as melhores terras agricultáveis de Roraima. Fazendas centenárias, produtivas - a produção de arroz supera um milhão de saca - que estão encravadas na área, representam extraordinária fonte de riqueza para o Estado e geram centenas de empregos. Há de se considerar também o imobilizado em equipamentos de última geração que compõem a frota de veículos e maquinário agrícola, além das benfeitorias constituídas de moradias, galpões, cercas, pastagens e aplicações em insumos, mãode-obra, sementes, etc. Como se vê, a questão é complexa e exige muito mais que solução por decreto. (...) Mas que se faça uma demarcação onde sejam ressalvadas, além dos municípios e vilas com perímetros urbanos que permitam seu desenvolvimento, também as áreas comprovadamente produtivas e geradoras de emprego e divisas. (...) Depois de 20 anos residindo em Roraima, dos quais 12 de atuação política ininterrupta, conheço de perto a realidade do índio roraimense e das comunidades indígenas em geral. A questão indígena brasileira não pode continuar sendo subordinada a discussões estéreis e emocionais. Necessária e urgente é a formulação de uma adequada e objetiva política indígena no nosso País. A meu ver, muito mais importante que um confusa política voltada quase que exclusivamente para a demarcação de reservas é a formulação de uma política integrada e abrangente, destinada às comunidades indígenas, com propostas estabelecendo diretrizes e ações corretas que permitam ao índio o exercício pleno de sua cidadania.; a possibilidade de seu acesso aos frutos do progresso econômico e social e a convivência, em alguns casos, com comunidades não-indígenas.

O Sr. Ernades Amorim (PPB-RO) - Nobre Senadora Marluce Pinto(...) O Governo está de parabéns por tê-la escolhido, até porque S. Ex $x^{\underline{a}}$ passou por esta Casa e sabe da dificuldade para abordar-se os problemas indígenas no Brasil. Há poucos dias, o nobre Senador fez um pronunciamento relacionado a essa questão indígena. Eu o apartei e disse dos nossos problemas no Estado de Rondônia. Imagine que repetindo - o nosso Estado tem várias reservas indígenas, uma delas criada pela fraqueza de um ex-Presidente da República que, para satisfazer interesses internacionais de ONG's e outros, criou uma reserva de 1.865 .000 hectares para menos de 100 índios.

O Sr. Romeu Tuma (PFL-SP) - V. Ex ${ }^{\underline{a}}$ me permite um aparte?

A Sra Marluce Pinto (PMDB-RR) - Ouço V. Ex ${ }^{\mathrm{a}}$ com prazer.

O Sr. Romeu Tuma (PFL-SP) - Senadora Marluce Pinto, não ocuparei 
muito o tempo de V. Ex $x^{\underline{a}}$ com um aparte. Esse é um tema tão delicado e tão sério (...) Não nasci em região de comunidades indígenas. Quis Deus que um dia, como Diretor da Polícia Federal, conhecesse de perto as dificuldades por que passam as comunidades indígenas para sobreviver em determinadas regiões, e até os efeitos positivos e, às vezes, negativos do contato com as comunidades brancas $\mathrm{V}$. Ex $x^{\mathrm{a}}$ falava da Raposa do Sol, e, para cá me dirigi, apenas para elogiar o seu trabalho e o de seu marido no Governo ${ }^{194}$, lutando para tentar solucionar aquela situação. (...)

A Sra Marluce Pinto (PMDB-RR)- Com referência ao aparte do Senador Romeu Tuma, embora S. Ex ${ }^{a}$ tenha frisado não ser natural da Amazônia, poucos têm dado tanta cooperação à nossa Região. Ainda me lembro da época em que presidi a Comissão do Projeto Calha Norte, da qual posteriormente fui Relatora em outra legislatura. V. Ex foi assíduo, batalhador, visitando a região de Surucucus e toda a região beneficiada pelo Programa Calha Norte. (...) Louvo que um Senador por São Paulo tenha tanto empenho em procurar solucionar conosco essas questões, porque, com as desigualdades regionais que enfrentamos, não é fácil resolvermos os problemas de uma região tão rica e tão ambicionada por estrangeiros. V. Ex ${ }^{\underline{a}}$ pôde comprovar que, não fosse 0 pelotão do Exército ali implantado, nem sei se ainda teríamos sobreviventes ianomâmis, porque Ihes falta até comida, Ihes falta assistência média, Ihes falta tudo. A pequena verba do Calha Norte tem garantido a sobrevivência desses índios e, principalmente, o Exército brasileiro e a Aeronáutica têm prestado grandes serviços à comunidade ianomâmi e região.

O Sr. Romeu Tuma (PFL-SP) - A vida daquelas comunidades depende das Forças Armadas, principalmente da Aeronáutica e do Exército, que conseguiu, graças a um esforço enorme do Ministério, instalar os pelotões de fronteira que constituem o Projeto Calha Norte, que foi praticamente interrompido, mas graças à luta de V. Ex ${ }^{\underline{a}}$, que, de vez em quando, consegue colocar no Orçamento algum recurso, ainda se mantém o projeto (Pinto, 1999).

As falas dos senadores Marluce Pinto e Ernades Amorim são representativas dos políticos da bancada amazônica que defendem projetos de desenvolvimento econômico para a sua região. Historicamente,

${ }^{194}$ A senadora Marluce Pinto é casada com o atual governador de Roraima Ottomar de Sousa Pinto (PSDB). 
esses congressistas usam os problemas de segurança como argumento para justificar a necessidade de investimento em atividades econômicas (Pasquis, 2003:57). Também deve ser destacado no trecho acima transcrito a visão positiva do senador Romeu Tuma sobre a presença militar em terras indígenas. Com raras exceções ${ }^{195}$, essa posição é compartilhada pelos parlamentares que participam das Comissões de Defesa do Congresso.

A importância atribuída pelos parlamentares ao trabalho assistencial que as Forças Armadas realizam na Amazônia reforça a percepção que os militares têm de si próprios como agentes do processo civilizatório na região.

Outro entusiasta do Programa Calha Norte e defensor da tese de que a Amazônia corre o risco de ser internacionalizada é o ex-senador Bernardo Cabral (PFL/AM). Cabral proferiu vários discursos sobre esse assunto ao longo de sua carreira parlamentar, mas vamos nos concentrar nos discursos proferidos entre os anos de 1996 e $2001 .{ }^{196}$ Nesse período, o senador usou a tribuna pelo menos 18 vezes para discursar sobre problemas de segurança e defesa na região amazônica. As fontes a partir das quais Cabral elaborava suas falas eram notícias publicadas em jornais e correios eletrônicos enviados por eleitores e militares da reserva.

Isso nos remete a uma discussão sobre a qualidade das informações que circulam nas Comissões de Defesa. Informações pouco confiáveis, como as que circulam na internet, ou pouco independentes, como as fornecidas por militares na reserva, representam a maioria das fontes a partir das quais os deputados e senadores tomam suas decisões políticas

\footnotetext{
${ }^{195}$ Apenas o Partido Verde vê com reservas a presença militar em terras indígenas. Ainda assim, o deputado Fernando Gabeira, representante do partido na CREDN, em seus relatos sobre a viagem que os parlamentares fizeram aos Pelotões Especiais de Fronteira na Amazônia, expressa sua admiração pelo trabalho que o Exército vem desenvolvendo na região. Os relatos de viagem do deputado Gabeira estão disponíveis em: $<$ www.gabeira.com.br $>$.

196 Os pronunciamentos do senador Bernardo Cabral podem ser consultados no site do Senado Federal: $<\underline{w w w . s e n a d o . g o v . b r}>$.
} 
para as áreas de segurança e defesa. Um exemplo lapidar de como informações parciais e pouco confiáveis são utilizadas nos trabalhos parlamentares pode ser encontrado no relatório da Comissão Externa do Congresso Nacional destinada a avaliar a situação da demarcação contínua da reserva indígena Raposa/Terra do Sol. O relator da Comissão, deputado Lindberg Farias (PT/RJ) ${ }^{197}$ argumenta que a demarcação contínua da reserva representaria uma ameaça à soberania nacional pois a área é contígua a uma "região de disputa entre a Venezuela e a Guiana". Ele também chama a atenção para a baixa densidade populacional na região de Raposa/Serra do Sol:

O vazio demográfico, conjugado com o acirramento dos conflitos indígenas e fundiários, pode favorecer a prática de atividades ilegais nas zonas de fronteira, tornando-as mais vulneráveis interna e externamente. O que explica a ênfase dos comandantes militares brasileiros na chamada vivificação das fronteiras. Ou seja, sua ocupação humana, com os objetivos de consolidar a presença brasileira em áreas estratégicas do território nacional, facilitar o combate a ilícitos nacionais e transnacionais e promover a dignidade das populações locais (Lindenberg, 2005:27).

No item do relatório "Pressões sobre a Amazônia", o deputado Lindberg Farias lista alguns comentários feitos por militares da reserva:

Chegou ao conhecimento desta Comissão que, em algumas oportunidades, os segmentos mais radicais da proteção aos indígenas se utilizam do termo "nação indígena", com a finalidade de intimidar a atuação das forças de segurança no interior de áreas demarcadas, como se fosse um território interdito ao patrulhamento ou à realização de operações.

O general Luiz Gonzaga Schroeder Lessa, excomandante militar da Amazônia e atual presidente do Clube Militar, em palestra à esta Comissão Externa na cidade de Pacaraima, em Roraima, demonstrou desconforto com a presença de pesquisadores da Nasa na equipe responsável por levantamentos ambientais feitos

197 Lindberg Farias atualmente é prefeito da cidade de Nova Iguaçu (RJ), eleito pelo Partido dos Trabalhadores. 
através de monitoramento por satélite. Esses estudos, destinados a controlar as queimadas e a investigar dados sobre ventos e outros fenômenos ambientais, fazem parte do Programa Piloto do G7 para a Proteção da Floresta Tropical do Brasil (PPG7), que é financiado pelo G7, pela União Européia e pelo Governo da Holanda e implementada por várias instituições - entre as quais, o Ministério do Meio Ambiente, a FUNAI e ONGs (Lindenberg, 2005:30-31).

E cita alguns documentos consultados na internet para justificar seus temores acerca da "autodeterminação dos povos indígenas":

O texto, recolhido no website oficial das Nações Unidas, enfatiza (...) a "necessidade de desmilitarização das terras e territórios dos povos indígenas" ("Emphasizing the need for demilitarization of the lands and territories of indigenous peoples"). O artigo terceiro da Declaração reconhece aos povos indígenas o direito à auto-determinação, bem como o direito de determinar livremente seu status político buscar seu desenvolvimento econômico, social e cultural. ("Indigenous peoples have the right of self-determination. By virtue of that right they freely determine their political status and freely pursue their economic, social and cultural development').

Outrossim, há ONGs que trabalham abertamente nesse sentido. Como exemplo, cite-se o International Indian Treaty Council, que congrega nações indígenas das Américas e do Pacífico, com sede em San Francisco, Califórnia, e que tem como missão declarada "trabalhar pela soberania e autodeterminação dos povos indígenas" ("The International Indian Treaty Council (IITC) is an organization of Indigenous Peoples from North, Central, South America and the Pacific working for the Sovereignty and Self-Determination of Indigenous Peoples and the recognition and protection of Indigenous Rights, Traditional Cultures and Sacred Lands") (Lindenberg, 2005:36-37).

O relatório de Lindberg Farias traz ainda, em anexo, uma indicação do deputado sugerindo que o Conselho de Defesa Nacional seja ouvido no caso da demarcação da reserva indígena Raposa/Serra do Sol.

O texto acima foi aprovado pela Comissão de Relações Exteriores e Defesa Nacional em 2004. Nesta ocasião, apresentaram voto em separado 
por discordarem do relatório do deputado Lindberg Farias, apenas seu colega de partido, o deputado Eduardo Valverde (PT/RO), e a deputada Perpétua Almeida (PC do B/AC). Na citação abaixo os deputados apresentam suas opiniões a respeito do relatório:

O Voto do Relator, por sua vez, comporta manifestações e juízos de valor que não nos parecem condizentes com a realidade dos fatos (...) Não há qualquer restrição à atuação das Forças Armadas e também do Departamento de polícia federal em áreas indígenas. A existência do Pelotões de Fronteira, em funcionamento em várias áreas indígenas, como na própria Raposa Serra do Sol, demonstram isso. Da mesma forma, desde a demarcação da Terra Indígena Yanomami, quando questões dessa natureza foram suscitadas, restou esclarecido em reiteradas manifestações do então Ministro da Justiça, o Senador Jarbas Passarinho e posteriormente reiteradas pelo Ministro Nelson Jobim, por ocasião da declaração dos limites da terra indígena do Médio Rio Negro, em 1995, que não há qualquer óbice à demarcação de terras indígenas em Faixa de Fronteira (...) A circunstância de existir na Guiana, um trecho de terras reivindicado pela Venezuela, em nada interfere com o Brasil, em especial pela ausência de qualquer tendência a solução armada dessa pendência entre estes dois países vizinhos;

A consideração das forças armadas de que na região fronteiriça do Brasil, na região norte registra-se "baixa densidade populacional", a exigir, de acordo com suas concepções de defesa estratégica do território nacional, a "vivificação da fronteira", conforme previsto na Política de Defesa Nacional aprovada em 1996, esbarra em óbice constitucional, inscrito no art. 231 da CF. Dessa forma, a necessária e possível compatibilização do imperativo constitucional da defesa do território nacional, com a defesa da integridade dos direitos dos índios sobre as terras que tradicionalmente ocupam, exigirá a adoção, pelo país e conseqüentemente de suas Forças Armadas, de outro método de afirmação do Estado nos limites fronteiriços. No caso, afigura-se perfeitamente exeqüível que os próprios índios venham a exercer essa função, na medida em que respeitosa e harmoniosamente venham a ser abordados sobre o assunto e venham a concordar com essa colaboração. Outro aspecto a ser considerado na região fronteiriça norte do país consiste no desenvolvimento de controles aéreos e fluviais do território, com aparelhamento da aeronáutica, da marinha e do exército de forma compatível; 
O item sobre "Pressões sobre a Amazônia" consiste em considerações genéricas sobre interesses políticos que são identificados sobre a Amazônia, mas que não guardam relação direta com a homologação da demarcação da TIRSS, razão pela qual não se justifica (Almeida, 2005: 04-08; Valverde, 2005:04-08).

No trecho acima, percebe-se que as críticas dos deputados não se dirigem à presença dos militares em terras indígenas, mas aos argumentos pouco convincentes utilizados pelo relator para defendê-la e à maneira como essa questão vem sendo tratada pelas Forças Armadas e pelo parlamento.

Como pudemos constatar neste capítulo, a idéia de que a soberania do Estado brasileiro sobre a Amazônia está de alguma forma ameaçada não está restrita à caserna. O Itamaraty, o Poder Executivo e o Legislativo têm buscado a seu modo responder as percepções de insegurança oriundas da fronteira norte. 


\section{CONSIDERAÇÕES FINAIS}

O olho que vê é o órgão da tradição.

Franz Boas

Durante várias décadas especialistas em Relações Internacionais e os estudiosos da dinâmica interna das instituições militares atribuíram a postura estratégica das Forças Armadas a uma conjugação de fatores materiais. No bojo dessa perspectiva, a política dos Estados seria a política do poder e o grupo que melhor expressaria a crueza das relações interestatais seriam os militares, responsáveis pela administração da violência legítima. Para compreender a "Alta Política", o analista deveria se desvencilhar de todo tipo de informação que pudesse turvar sua visão. "Os fatos históricos entronizados no reino das lendas" ${ }^{198} \mathrm{em}$ nada contribuiriam para a análise das questões estratégicas. As estratégias militares seriam construídas em resposta às ameaças externas e as Forças Armadas que enfrentassem ameaças semelhantes reagiriam da mesma forma. Numa região pacífica e sem visualizar uma ameaça concreta no cenário estratégico, os militares tentariam preservar ao máximo seus interesses paroquiais e prefeririam sempre estratégias que permitissem aumentar seu orçamento e sua autonomia. A análise do pensamento militar sobre a Amazônia e das estratégias militares escolhidas para defender a região mostra as limitações desse tipo de abordagem teórica.

A transferência de unidades militares das regiões sul-sudeste para a região amazônica que, à primeira vista, pode ser interpretado como uma resposta do Estado brasileiro às ameaças externas percebidas à região, na verdade reflete as mudanças operadas na identidade institucional das Forças Armadas. Depois de passar mais de vinte anos atuando prioritariamente na defesa da ordem política instituída pelo golpe de 1964, os militares brasileiros estão cada vez mais voltados para uma missão

${ }^{198}$ Tucídides (2004:12). 
militar clássica: garantir a soberania brasileira sobre todo o território nacional.

No imaginário militar a soberania brasileira sobre a Amazônia só pode ser mantida através da presença das Forças Armadas na região. Esta percepção, no entanto, não é orientada apenas pela identificação de ameaças externas. A idéia de que os militares são os avalistas da integração nacional é um dos principais traços da cultura estratégica das Forças Armadas brasileiras.

Os mitos criados pelas Forças Armadas para representar sua missão na Amazônia nos ajudam a compreender melhor o significado que a instituição atribui à sua presença na Amazônia. $\mathrm{O}$ culto a figuras históricas que desempenharam funções políticas na região durante o período colonial revela que os militares crêem estar cumprindo na Amazônia uma missão semelhante a que foi cumprida pelos colonizadores portugueses nos séculos XVII e XVIII.

Do Império lusitano na América, os militares brasileiros não cultuam apenas os heróis. As Forças Armadas brasileiras reverenciam também a visão geopolítica dos portugueses. A construção de fortalezas para assegurar a posse da terra, uma tradição militar portuguesa é recuperada pelo Exército através da construção de Pelotões Especiais de Fronteira na Amazônia.

Os Pelotões Especiais de Fronteira são unidades militares cuja principal missão em tempo de paz é induzir o povoamento de uma determinada porção do território. Sua capacidade de combate é bastante restrita. Portanto, é equivocada a idéia de que ao instalar os PEF na Amazônia os fardados tivessem apenas a intenção de aumentar a segurança militar na área.

O sentido da presença das Forças Armadas na Amazônia é duplo: civilizatório e estratégico-militar. No âmbito estratégico-militar, o argumento castrense é que uma fronteira "vivificada" é mais segura e mais fácil de ser defendida. No âmbito político, é preciso lembrar que os governantes brasileiros sempre atribuíram aos militares missões ligadas ao 
desenvolvimento nacional. Por isso é bastante freqüente no discurso militar a lembrança de que as atividades subsidiárias realizadas pelos fardados na Amazônia são atribuições constitucionais da instituição militar.

Retomando a tese de Elizabeth Kier, é preciso ter em mente que quando as Forças Armadas constroem suas estratégias militares, elas fazem-no tendo como referência o balanço de poder doméstico, ou seja, a co-relação de forças entre os atores políticos nacionais. No que concerne à presença militar na Amazônia, a pesquisa mostrou que os políticos vêem a atuação dos militares na região de forma bastante positiva, e, de maneira geral, não contestam as estratégias militares escolhidas para defender o país. A pouca atenção dispensada pelo mundo político às questões relacionadas à Defesa Nacional, permite que os militares ajam com um elevado grau de autonomia na Amazônia, mas nem por isso os fardados colocam entre suas opções estratégicas aquelas que poderiam thes render mais recursos financeiros e liberdade operacional.

As estratégias da presença e da resistência oferecem poucas oportunidades materiais às Forças Armadas brasileiras. Sobre a estratégia da presença é possível argumentar que se de fato esta estratégia não permite aos militares reivindicar grandes montantes de recursos orçamentários para o investimento em tecnologia, armamentos ofensivos, etc., ela confere prestígio político aos fardados, uma vez que esta estratégia envolve a execução de atividades que não são de natureza militar, como a construção e a manutenção de estradas e a prestação de serviços médicos e odontológicos à população local.

Já a opção pela estratégia da resistência não oferece aos militares nem oportunidades materiais, nem prestígio político. Tida como a mais política das estratégias, a resistência depende fortemente do apoio popular e governamental para sua consecução. Portanto, não é possível concluir que a escolha dessa estratégia militar seja orientada por uma ação autointeressada dos fardados visando acumular recursos orçamentários ou preservar a autonomia operacional.

Em suma, quando as Forças Armadas brasileiras constroem suas estratégias militares para a defesa da Amazônia, elas fazem-no orientadas 
por uma cultura estratégica que condiciona a leitura institucional dos contextos internacional, regional e nacional. Não são as ameaças externas nem os interesses paroquiais que determinam a priori as opções estratégicas dos militares. Parafraseando Franz Boas o olho institucional que vê as possíveis ameaças à soberania nacional sobre a Amazônia é o órgão da tradição militar brasileira. 


\section{Anexo 1}

PORTARIA № 020 - EME, DE 2 DE ABRIL DE 2003

Aprova a Diretriz para 0 relacionamento do Exército Brasileiro com as comunidades indígenas.

O CHEFE DO ESTADO-MAIOR DO EXÉRCITO, no uso da competência que lhe confere o art. 117, da Portaria n- 041, de 18 de fevereiro de 2002 (IG 10-42), resolve:

Art. 1을 Aprovar a Diretriz para o relacionamento do Exército Brasileiro com as comunidades indígenas.

Art. 2으 Os Órgãos de Direção Setorial, os Comandos Militares de Área e os demais Órgãos envolvidos adotem, em seus setores de competência, as providências decorrentes.

Art. 3- Estabelecer que esta Portaria entre em vigor na data de sua publicação.

DIRETRIZ PARA O RELACIONAMENTO DO EXÉRCITO BRASILEIRO COM AS COMUNIDADES INDÍGENAS

\section{FINALIDADE}

Orientar as atividades a serem desenvolvidas e os procedimentos adotados pelo Exército Brasileiro (EB) no relacionamento com as comunidades indígenas.

\section{REFERÊNCIAS}

- Constituição Federal (1988);

- Lei no 6001, de 19 de dezembro de 1973- Estatuto do Índio;

- Decreto Presidencial não numerado, de 22 de agosto de 2002, que criou o Parque Nacional Montanhas do Tumucumaque, no Estado do Amapá, e dá outras providências;

- Decreto no 4.411, de 7 de outubro de 2002, que dispõe sobre a atuação das Forças Armadas e da Polícia Federal nas unidades de conservação e dá outras providências; 
- Decreto no 4.412, de 7 de outubro de 2002, que dispõe sobre a atuação das Forças Armadas e da Polícia Federal nas terras indígenas e dá outras providências; e

- Diretrizes Gerais do Comandante do Exército - 2003.

\section{PREMISSAS BÁSICAS}

a. O Exército Brasileiro reconhece os direitos dos índios e mantém, historicamente, um excelente relacionamento com as comunidades indígenas, tendo o Marechal Rondon como paradigma desse relacionamento.

b. É de interesse da Força Terrestre manter um estreito relacionamento com as comunidades indígenas em todo o território nacional, particularmente na Amazônia, para complementar a estratégia da presença na região.

c. A cooperação mútua com as comunidades indígenas precede à formação do Exército Brasileiro. Brancos, negros e índios lutaram juntos em Guararapes pela libertação da terra, pela primeira vez identificada como Pátria.

\section{ORIENTAÇÃO GERAL}

a. É fundamental que todos os escalões da Força Terrestre compreendam que os índios são nativos da terra e que lhes são reconhecidos os costumes, sua organização social, a língua, as crenças e as tradições, além dos direitos originários sobre as terras que, tradicionalmente, ocupam. Cabe à União demarcá-las, protegê-las e fazer respeitar todos os seus bens, podendo o Exército Brasileiro sempre que possível, cooperar com a demarcação e estudar formas de participação e apoio destinadas a melhorar a sobrevivência e as condições de vida das comunidades indígenas.

b. É importante que todos os militares, especialmente aqueles que terão contato direto com as comunidades indígenas, conheçam e respeitem os hábitos, os costumes e as tradições, de forma a tornar harmônica e proveitosa para a Força Terrestre a convivência com os indígenas em o todo território nacional.

c. Por conhecer melhor a região onde vive e estar a ela perfeitamente adaptado, o índio pode constituir-se em um valioso aliado na obtenção de dados sobre a região, nas operações e nas ações rotineiras da tropa.

\section{ATRIBUIÇÕES PRINCIPAIS}

a. Estado-Maior do Exército (EME)

1) Coordenar as atividades dos órgãos de direção setorial e dos comandos militares de área que envolvam o relacionamento do Exército Brasileiro com as comunidades indígenas. 
2) Acompanhar as ações e emitir pareceres referentes à atividade da Força Terrestre relacionada ao assunto.

3) Considerar, quando do estudo de instalação ou transferência de unidades para as Terras Indígenas ou áreas próximas, o constante da Política de Gestão Ambiental do Exército (PGAEB) e da Diretriz Estratégica de Gestão Ambiental (DEGAEB), visando a neutralizar ou minorar o impacto sócio-ambiental que tais instalações podem causar.

4) Após a definição dos locais para a instalação de Organização Militar(OM) em Terras Indígenas ou próximas delas, informar às comunidades indígenas, bem como suas instâncias representativas.

\section{b. Comando de Operacões Terrestres (COTER)}

Incluir, no Programa de Instrução Militar, orientações para as OM localizadas nas áreas onde exista populações indígenas, sobre o trato com a mesma, principalmente com aqueles ainda não totalmente integrados à comunidade.

\section{c. Departamento de Ensino e Pesquisa (DEP)}

1) Incluir nos currículos das Escolas de Formação e Aperfeiçoamento assuntos referentes à situação geral das comunidades indígenas no Brasil, à legislação e ao processo de demarcação e homologação das Terras Indígenas.

2) Incluir no currículo da Escola de Comando e Estado-Maior, assuntos referentes à política indigenista brasileira e suas interações com o direito humanitário e com a soberania nacional.

\section{d. Departamento de Engenharia de Construcão (DEC)}

1) Quando solicitado, fornecer ao EME parecer da conveniência para a Força Terrestre, da demarcação de terras indígenas, sob a ótica patrimonial.

2) Quando da realização de obras ou serviços técnicos em áreas indígenas considerar as medidas necessárias para a minimização do impacto sócio-ambiental às comunidades indígenas.

\section{e. Departamento Geral do Pessoal (DGP)}

Estabelecer, quando conveniente para o EB, convênios com a FUNAl, visando a apoiar projetos de saúde para as populações indígenas, mediante utilização da Organização Militar de Saúde mais próxima.

\section{f. Secretaria de Tecnologia da Informação (STI)}

Quando da realização de serviços técnicos em Terras Indígenas considerar as medidas necessárias para a minimização do impacto sócio-ambiental às comunidades indígenas.

\section{g. Comandos Militares de Área (C Mil A)}


1) Estabelecer normas próprias de convivência, quando for o caso, com vistas a orientar a conduta de militares ao tratar com os silvícolas, considerando as características e diversidade de cada grupo indígena.

2) Programar estágios para todos os militares que possam vir a ter contato com as comunidades indígenas, sempre que possível, com a participação de antropólogos, representantes da FUNAl e de outras autoridades no assunto.

3) Quando da seleção para o serviço militar inicial, priorizar a incorporação de jovens oriundos das comunidades indígenas, desde que voluntários e aprovados no processo de seleção. 


\title{
ANEXO 2
}

\section{CANÇÃO DO $6^{\circ}$ BEC}

\author{
A MAIS BELA BATALHA \\ SUPERANDO DAS ÁGUAS A FÚRIA, \\ ABATENDO DAS SELVAS OS GIGANTES, \\ AVANÇAMOS, SUGANDO AS PLANURAS, \\ COM VIGOR DE MODERNOS TITÃS. \\ ENFRENTANDO A FLORESTA INFINDÁVEL, \\ NUNCA PARAM OS NOSSOS TRATORES, \\ PELAS SERRAS E INGENTES CAUDAIS. \\ NUM CONTÍNUO RUGIR DE MOTORES. \\ BATALHÃO DE NOVOS PIONEIROS, \\ SEGUIDORES DO EXEMPLO IMORTAL \\ DE ENGENHEROS HERÓICOS, GUERREIROS
}

DUMA GUERRA COMO NUNCA OUVE IGUAL. (ESTRIBILHO)

\author{
COMPANHIA DE AUDAZES, INDÔMITOS \\ BANDEIRANTES DE RAÇA VIRIL, \\ ANSIOSOS POR VER A AMAZÔNIA \\ PARA SEMPRE INTEGRADA AO BRASIL \\ ALCAÇANDO LONGÍNQUAS FRONTEIRAS \\ RELEMBRAMOS A NOSSA HISTÓRIA: \\ SEMPRE HÁ UM SOLDADO-ENGENHEIRO \\ NAS ORIGENS DE TODA VITÓRIA. \\ RODOVIAS E QUARTÉIS IMPLANTANDO, \\ PROSSEGUIMOS, COM A FÉ MAIS PROFUNDA \\ CONVECIDOS QUE ESTAMOS LUTANDO \\ NA MAIS BELA BATALHA DO MUNDO. \\ BATALHÃO DE NOVOS PIONEIROS, \\ SEGUIDORES DO EXEMPLO IMORTAL \\ DE ENGENHEROS HERÓICOS, GUERREIROS
}

DUMA GUERRA COMO NUNCA OUVE IGUAL. (ESTRIBILHO)

COMPANHIA DE AUDAZES, INDÔMITOS

BANDEIRANTES DE RAÇA VIRIL, 
ANSIOSOS POR VER A AMAZÔNIA

PARA SEMPRE INTEGRADA AO BRASIL 


\section{Anexo 3}

CANÇÃO DO SOLDADO DA AMAZÔNIA

AUTOR: CEL INF OSWALDO DO PASSO MATOSO MAIA

NOSSA ORIGEM SE PRENDE ÀS GLÓRIAS DA BRAVURA SEM PAR DAS BANDEIRAS, POIS DE PEDRO TEIXEIRA AS VITÓRIAS DEMARCARAM AS NOSSAS FRONTEIRAS ESTES FEITOS HERÓICOS DA HISTÓRIA E O POVO ANCESTRAL DENODADO ESTÃO SEMPRE PRESENTES À MEMÓRIA NAS AÇÕES DE SEU FORTE SOLDADO

VAMOS, COMPANHEIROS AVANTE COM DESASSOMBRO TOTAL PARA VERMOS, TRIUNFANTES NA PÁTRIA O NOSSO IDEAL

VALOROSOS VIGIAS TENAZES, DE PRESENÇA ALTIVA E VALOR SENTINELAS DA SELVA AUDAZES, AO BRASIL DEDICAMOS AMOR DESTEMIDOS E BRAVOS SOLDADOS ESTA TERRA JURAMOS GUARDAR E CUMPRIR OS DEVERES SAGRADOS

DA GLORIOSA MISSÃO MILITAR

VAMOS, COMPANHEIROS AVANTE COM DESASSOMBRO TOTAL PARA VERMOS, TRIUNFANTES NA PÁTRIA O NOSSO IDEAL

SELVA! 


\section{Anexo 4}

Oração do Guerreiro de Selva

Autor: Humberto Batista Leal

"Senhor! Tu que ordenaste ao guerreiro de selva:

'Sobrepujai todos os vossos oponentes!',

dai-nos hoje da floresta:

a sobriedade para persistir,

a paciência para emboscar,

a perseverança para sobreviver,

a astúcia para dissimular

e a fé para resistir e vencer!

E dai-nos também, Senhor,

a esperança e a certeza do retorno,

mas se defendendo esta brasileira Amazônia

tivermos que perecer, ó Deus!,

que o façamos com dignidade

e mereçamos a vitória!

Selva!" 


\section{Anexo 5}

\section{CANÇÃO DO CIGS}

Tempestades, chavascais, charcos e espinhos,

Perigo à espreita na mata tão voraz,

Sombras e silêncio pelas trilhas e caminhos,

Guerra na Selva, um teste eficaz.

A fraterna convivência nos ensina,

O valor de uma sã camaradagem,

Com justiça liberdade, com estima, Sempre alerta com bravura e coragem.

\section{Estribilho}

Nós somos uma tropa de vanguarda,

Para quem o perigo não existe,

Com orgulho usamos esta farda, Investindo com as armas sempre em riste.

À Amazônia inconquistável o nosso preito, A nossa vida por tua integridade,

A nossa luta pela força do direito

Com o direito da força em validade.

Se a selva não pertence ao mais forte, Mas ao sóbrio habilidoso e resistente, Temos tudo pra lutar até com a morte, No perigo nossa força está presente.

\section{Estribilho}

Nós somos uma tropa de vanguarda,

Para quem o perigo não existe,

Com orgulho usamos esta farda, Investindo com as armas sempre em riste. 


\section{Anexo 6}

Sentinela-Amazônida

Autor: Cel. de Infantaria William da Rocha

IGARAPÉ, BARCO, MONTARIA

ESTRADA, CAMINHO E VIA.

RAMA, TRAMA, E RAÍZES,

SOLO, SOALHO, SEARA, FAZENDA, RAMO, REMO E RENDA.

LÍQUIDO LEITO FEITO DE RIO

RELVA, SELVA E SENDA

REPLETA DE SEIVA A RENDA

DO VERDE MACIO.

SE ELEVA AO CÉU O SOM E O SOL,

O SILVO, O FARO, A FERA E O CIO, VERDE-OLIVA, CHAMA-VIVA

NO VERDE FIO

D'ESPERANÇA

O NEGRO RIO SE LANÇA

E SE UNE À FLORESTA.

MERGULHA N'ALMA, MISTURA CALOR E CALMA

TRAZ O QUE RESTA.

DEVER, A LUTA CONDUZ,

VIBRA, IMPULSIONA, SEDUZ, CADA DIA, ETERNA FESTA.

CASTANHEIRA, CACHOEIRA, BEIRA, BORDA E BARRANCA, GROTA, BROTA E ARRANCA, FRUTO, LENHO, OURO, MINA. NO REGAÇO DA MÃE DIVINA POUSO NO TRAÇO DE TERRA. TRAÇO NO AR O IR

AO VIR AO PAGO SEM PREÇO, VENHO AO FIM E AO COMEÇO, MEREÇO E OUSO VIR.

DA SELVA E DO RIO ECOA, SOA RESSOA E ARREBATA, O GRITO DA FERA, A LENDA E O MITO. ETERNA ALVORADA NA BELA MATA, DESFRALDADA BANDEIRA FITO.

NA FORTE E DURA LIDA, COMBATENTE, EU SOU A VIDA, SEM PREÇO, COMEÇO NEM FIM, SOU REPRESENTANTE AVANÇADO, SENTINELA-AMAZÔNIDA, SOLDADO, O BRASIL VIVENDO EM MIM. 


\section{Anexo 7}

\section{Bandeirante do Ar}

Letra e Música: Luiz Felipe de Magalhães (Cadete do Ar)

Transcrição Musical: Maestro Ten. J. Nascimento

A esquadrilha é um punhado de amigos,

A vibrar, a vibrar de emoção

Não tememos da luta os perigos

Nem dos céus a infinita amplidão

Sobre mares, planícies, sobre montes

Viveremos por sempre a voar

Bandeirantes de novos horizontes

Para a bandeira da Pátria elevar

Bandeirantes de novos horizontes

Para a suprema conquista do ar

Nós somos da Força Aérea Brasileira

Nosso emblema é a águia altaneira

Que há de ser grande, forte e varonil!

Lutaremos, morreremos

Pela bandeira do Brasil

Lutaremos, morreremos

Pela bandeira do Brasil

Entre as nuvens, nos céus, vendo a terra

Vivem lá os cadetes do ar

Comandando a grande arma de guerra

Baluarte da pátria sem par

Adestrados ao fogo da metralha

E ao governo de seu avião

Estarão sempre prontos à batalha

Para defesa do nosso torrão

Estarão sempre prontos à batalha

Por defender o auriverde pendão!

Nós somos da Força Aérea Brasileira

Nosso emblema é a águia altaneira

Que há de ser grande, forte e varonil!

Lutaremos, morreremos

Pela bandeira do Brasil

Lutaremos, morreremos

Pela bandeira do Brasil 


\begin{abstract}
Anexo 8
Canção do Sétimo Comando Aéreo Regional

Letra e Música: SO SMU Gilmar da Silva

I

Salve, ó Grande Sétimo COMAR,

Sentinela da Amazônia Ocidental,

Tua frota audaz do azul

Sobrevoa este esplendor de Norte a Sul,

Imenso verde com águas e riquezas,

O desafio das longínquas fronteiras.

No teu exemplo de coragem e presteza,

És pássaro defendendo a natureza.

\section{ESTRIBILHO}

És o Sétimo Comando Aéreo Regional,

Tu és história na Amazônia Ocidental,

Galardão da Força Aérea Brasileira,

Defende no espaço a sagrada Bandeira.
\end{abstract}

Não importa o perigo da missão,

Bravos soldados, amigos irmãos,

Vigiamos, camuflados e guerreiros, 
Incansáveis guardiães e mensageiros.

No ar, na terra e no coração da selva,

És o escudo na paz ou na guerra.

Fazendo o bem e combatendo o mal

Simbolizas nosso nobre ideal.

\section{ESTRIBILHO}

És o Sétimo Comando Aéreo Regional,

Tu és história na Amazônia Ocidental

Galardão da Força Aérea Brasileira,

Defende no espaço a sagrada Bandeira. 


\section{REFERÊNCIAS BIBLIOGRÁFICAS}

\section{Artigos, Ensaios e Livros.}

ABREU, Gustavo de Souza. Reflexões sobre a Doutrina da Resistência. Revista do Exército Brasileiro, Rio de Janeiro, v. 140, p.24-32, 3. Quadrimestre 2003.

AERONÁUTICA. Aeronáutica Brasileira 1995-1998. Brasília, DF: Opção, 1998.

AEROVISÃO. $2^{\circ} / 3^{\circ}$ GAV - Esquadrão Grifo. Aerovisão. Brasília, DF, ano XXIII, n. 197, jan./abr. 1999.

ALVES, Maria Helena Moreira. Estado e oposição no Brasil: 1964 - 1984. Petrópolis: Vozes, 1984.

ASSIS, Jorge César de. Interceptação e Abate de Aeronave: Considerações sobre a Lei n. 9.614, de 05.03.1998. Disponível em: <http://www.cesdim.org.br/arquivo/29.doc>. Acesso em: 19 abr. 2007.

BECKER, Bertha K. Brazil-Tordesilhas, Year 2000. Political Geography. Pergamon, 20, p.709-725, 2001.

futuro. Mimeo, 2002.

Integração física e ocupação da Amazônia: estratégia para o

BENTO, Cláudio Moreira. A necessidade de uma "História Militar Terrestre da Amazônia". A Defesa Nacional, Rio de Janeiro, ano LXXXVII, n. 790, p. 133-138, maio/ jun./ jul./ago. 2001.

BOBBIO, Norberto; MATTEUCCI, Nicola; PASQUINO, Gianfranco.

Dicionário de Política. 12 ed. Brasília, DF: UNB, 2004, 2 v.

BUZAN, Barry; WÆEVER, Ole; WILDE, Jaap de. Security: a New Framework for Analysis. Boulder, CO: Lynne Rienner Publishers, 1998.

CARDOSO, Alberto Mendes. Os 13 momentos da arte da guerra: uma visão brasileira da obra de Sun Tzu. Rio de Janeiro: Record, 2005.

CARVALHO, Aildon Dornellas de. Amazônia: reflexões sobre a conquista e o desenvolvimento. Rio de Janeiro: Imprensa Técnica do Parque de material de Eletrônica da Aeronáutica, 2000.

CARVALHO, José Murilo de. As Forças Armadas na Primeira República: o poder desestabilizador. In: CARVALHO, José Murilo de. Forças Armadas e Política no Brasil. Rio de Janeiro: J. Zahar, 2005.

CASTRO, Celso; D’Araujo Maria Celina. Militares e política na Nova República. Rio de Janeiro: FGV, 2001.

. A invenção do Exército brasileiro. Rio de Janeiro: J. Zahar, 2002.

Os militares e os outros: Amazônia, defesa nacional, e identidades

sociais In: XXVII Encontro Anual da ANPOCS, 21 a 25 de outubro, Caxambu, 2003. 
espírito militar: um estudo de antropologia social na Academia Militar das Agulhas Negras. 2.ed. rev. Rio de Janeiro: J. Zahar, 2004.

; SOUZA, Adriana Barreto de. A defesa militar da Amazônia: entre história e memória. In: CASTRO, Celso (Org.). Amazônia e Defesa Nacional. Rio de Janeiro: FVG, 2006. Cap. 2, p.31-67.

CAVAGNARI, Geraldo Lesbat. Defesa com Democracia e Desenvolvimento. Teoria e Debate, São Paulo, n. 24, mar./abr./maio 1994. Disponível em: http://www2.fpa.org.br/portal/modules/news/article.php?storyid=1248.

Acesso em: 12 fev. 2004. Introdução à defesa da Amazônia. Carta Internacional, ano X, n. 107-108, p. 19-21, janeiro/fevereiro 2002.

COELHO, Edmundo Campos. Em busca da identidade: o Exército e a Política Brasileira. Rio de Janeiro: Record, 2000.

COMBLIN, Joseph. A ideologia da Segurança Nacional: o poder militar na América Latina, Rio de Janeiro: Civilização Brasileira, 1978.

COOLEY, Alexander. Democratization and the Contested Politics of U.S. Military Bases in Korea: Towards a Comparative Understanding. IR Review, v. 10, n. 2, p. 201-232, Autumn 2005.

Base Motives: The Political Economy of Okinawa's Antimilitarism. Armed Forces \& Society, v. 32, n. 4, p. 566-583, July 2005.

DEUTSCH, Karl W. Análise das Relações Internacionais. Brasília, DF: UNB, 1982.

DIACON, Todd A. Rondon: o marechal da floresta. São Paulo: Companhia das Letras, 2006. (Coleção perfis brasileiros).

DOMINGOS NETO, Manuel. Influência estrangeira e luta interna no Exército (1889-1930). In: ROUQUIÉ, Alain (Coord.). Os partidos militares no Brasil. Rio de Janeiro: Record, [1991]. Cap. 3, p.43-70.

DUARTE, Paulo de Queiroz. A influência da História na Doutrina Militar. A Defesa Nacional, Rio de Janeiro, n. 715, p. 117-12, set./ out. 1984.

ELIA, Rui da Fonseca. A Marinha na Amazônia Ocidental. Revista Marítima Brasileira, Rio de Janeiro, v. 120, n. 7-9, p. 69-86, jul./set. 2000.

EVERA, Stephen van. Offense, Defense, and the Cause of War. International Security, v. 22, n. 4, p.05-43, Spring 1998.

EYRE, Dana P.; SUCHMAN, Mark C. Status, Norms, and the Proliferation of Conventional Weapons: An Institutional Theory Approach. In: KATZENSTEIN, Peter J. (Ed.). The Culture of National Security. Norms and Identity in World Politics. New York: Columbia University Press, 1996. Cap. 3, p. 79-113.

FARAGE. As muralhas dos sertões: os povos indígenas no Rio Branco e a colonização. Rio de Janeiro: Paz e Terra; ANPOCS, 1991. 
FERREIRA, Aurélio Buarque de Holanda. Novo Aurélio Século XXI: o dicionário da língua portuguesa. 3. ed. rev. Rio de Janeiro: Nova Fronteira, 1999.

FIGUEIREDO, Argelina Cheibub, LIMONGI, Fernando. Executivo e Legislativo na Nova Ordem Constitucional. Rio de Janeiro: FGV, 1999.

FLEMES, Daniel. Militares e parlamento na América Latina: uma reflexão crítica sobre a função de controle das Comissões de Defesa brasileiras. In: RESDAL - Red de Seguridad y Defensa, Buenos Aires, fev. 2004.

Disponível em: <http://www.resdal.org/docs-flemes.html>. Acesso em: 30 maio 2004.

FONSECA, Paloma Siqueira. A presiganga e as punições da Marinha (1808-31). In: CASTRO, Celso; IZECKSOHN, Vitor; KRAAY, Hendrik. Nova história militar brasileira. Rio de Janeiro: FGV/Bom Texto, 2004. Cap. 5, p.139-157.

FORJAZ, Cláudio Ricardo Hehl. General Vô Nguyen Giap - um mestre da estratégia da resistência. A Defesa Nacional, Rio de Janeiro, ano LXXXV, 3. Quadrimestre, n. 785, p. 90-107, set./ out./ nov./dez. 1999.

FORJAZ, Cláudio Ricardo Hehl. General Vô Nguyen Giap - um mestre da estratégia da resistência (conclusão). A Defesa Nacional, Rio de Janeiro, ano LXXXVI, 1. Quadrimestre, n. 786, p. 70-83, jan./ fev./ mar./abr. 2000.

FORTUNA, Hernani Goulart. Amazônia: Realidade e Visão PolíticaEstratégica. Revista Marítima Brasileira, Rio de Janeiro, v. 114, n. 1-3, p. 51-59, jan./mar. 1994.

Amazônia: uma visão política-estratégica. Revista Marítima Brasileira, Rio de Janeiro, v. 123, n. 7-9, p. 81-92, jul./set. 2003.

GUIMARÃES, Leonan dos Santos. O que é desenvolvimento sustentável. Revista Marítima Brasileira, Rio de Janeiro, v. 123, n. 7-9, p. 179-182, jul./set. 2003.

; CONCEIÇÃO JÚNIOR. Sistema de Armas Fluvial para a região amazônica. Revista Marítima Brasileira, Rio de Janeiro, v. 121, n. 10-12, p. 193-204, out./dez. 2001.

HECK, Egon Dionísio. SIPAM e a autodeterminação na Amazônia. In: OLIVEIRA, José Aldemir; GUIDOTTI, Humberto. A Igreja arma sua tenda na Amazônia. Manaus: EDUA, 2000, p. 95-105.

; LOEBENS, Francisco; Priscila D. Carvalho. Amazônia indígena: conquistas e desafios. Estudos Avançados, v. 9, n. 53, São Paulo, 2005, p. 237-255.

HOLANDA, Sérgio Buarque de. A Fronda Pretoriana. In: HOLANDA, Sérgio Buarque de (Coord.). Do Império à República. 4. ed. São Paulo: Difel, 1985. (Coleção História Geral da Civilização Brasileira, Tomo II. O Brasil Monárquico, v. 5). Cap. 3, p.306-347.

HUNTINGTON, Samuel P. O Soldado e o Estado. Teoria e Política das Relações entre Civis e Militares. Rio de Janeiro: Biblioteca do Exército, 1996. 
JOHNSTON, Alastair I. Thinking about strategic culture. International Security, v. 19, n. 4, p.32-64, Spring 1995a.

Cultural Realism: Strategic Culture and Grand Strategy in Chinese History. Princeton, New Jersey: Princeton University Press, $1995 \mathrm{~b}$.

Cultural Realism and Strategy in Maoist China. In: KATZENSTEIN,

Peter J. (Ed.). The Culture of National Security. Norms and Identity in World Politics. New York: Columbia University Press, 1996. Cap. 7, p. 216-268.

KEOHANE, Robert; NYE, Joseph S. Poder y interdependencia: la política mundial en transición. Buenos Aires: Grupo Editor Latinoamericano, 1988.

KIER, Elizabeth. Culture and French Military Doctrine before World War II. In: KATZENSTEIN, Peter J. (Ed.). The Culture of National Security. Norms and Identity in World Politics. New York: Columbia University Press, 1996. Cap. 6, p. 186-215.

Imagining War: French and British Military Doctrine between the Wars. Princeton, New Jersey: Princeton University Press, 1997.

KIWIELEWICZ, Maurício. Análise de Defesa da Amazônia: Modelos de Combate na Selva. Revista Marítima Brasileira, Rio de Janeiro, v. 117, n. 13, p. 169-180, jan./mar. 1997.

KRATOCHWILL, Frederich; LAPID, Yosef (Ed.). The Return of Culture and Identity in International Relations Theory. London: Lynne Rienner, 1997.

LEIRNER, Piero de Camargo. O Exército e a questão amazônica. Estudos Históricos. Rio de Janeiro: FGV, n. 15, 1995. Disponível em:

$<$ http://www.cpdoc.fgv.br/revista/arq/167.pdf >. Acesso em: 12 fev. 2004.

Meia-volta, volver: um estudo antropológico sobre a hierarquia militar. Rio de Janeiro: FGV, 1997.

LEIS, Hector R. (org.). Ecologia e política mundial. Rio de Janeiro:

Vozes/FASE, 1991.

LESSA, Luiz Gonzaga Schröeder. Um Olhar para o Norte - Venezuela.

Idéias em Destaque, Rio de Janeiro, n. 23, p. 24-26, jan./abr. 2007.

LIMA, Fernando. Inconstitucionalidade da Lei do Abate. Disponível em:

$<$ http://www.tex.pro.br/wwwroot/02de2004/inconstitucionalidadedaleidoabat efernandolima.htm >. Acesso em: 19 abr. 2007.

LORCH, Carlos. Do CAN ao SIVAM: a FAB na Amazônia. Rio de Janeiro: Aerospace, 2000.

LUTZ, Catherine A. Homefront: A Military City and the American $20^{\text {th }}$ Century. Boston, MA: Beacon Press, 2001.

MARCH, James; SPROULL, Lee S.; TAMUZ, Michael. Learning from Samples of One or Fewer. Organization Science, v. 2, n. 1, p. 01-13, 1991.

MARQUES, Adriana A. A estratégia amazônica do Exército brasileiro e o surgimento de uma comunidade de segurança no Sul da América Latina. Arbeispapiere des Institut für Iberoamerika-Kunde, Hamburg, n. 21, Oktober 2004a. 
El Ministerio de Defensa en Brasil:limitaciones y perspectivas. Revista Fuerzas Armadas y Sociedad, Año 18, n. 3-4, p.1-11, JulioDiciembre 2004b.

Presença Militar na Amazônia: a visão do Poder Legislativo. In: CASTRO, Celso (Org.). Amazônia e Defesa Nacional. Rio de Janeiro: FVG, 2006. Cap. 3, p. 69-96.

MARTINS FILHO, João Roberto. O palácio e a caserna: a dinâmica militar das crises políticas na ditadura. São Carlos, SP: Edufscar, 1995.

; ZIRKER, Daniel. Nationalism, National Security and Amazônia: Military Perceptions and Attitudes in Contemporary Brazil. Armed Forces \& Society, n. 27, p. 105-129, Fall 2000.

A visão militar sobre as novas ameaças no cenário da Amazônia brasileira. In: MATHIAS, Suzeley Kalil; SOARES, Samuel Alves (Orgs.). Novas ameaças, dimensões e perspectivas: desafios para a cooperação entre Brasil e Argentina. São Paulo: Sicurezza, 2003, p. 245-279.

O governo Fernando Henrique e as Forças Armadas: um passo à frente, dois passos atrás. Disponível em:

$<$ www.crab.rutgers.edu/ goertzel/martins. html>. Acesso em: 12 set. 2004.

As Forças Armadas brasileiras e o Plano Colômbia. In: CASTRO, Celso (Org.). Amazônia e Defesa Nacional. Rio de Janeiro: FVG, 2006. Cap. 1, p.13-29.

MARTINS, Marseno Alvim. A Amazônia e nós. Rio de Janeiro: Biblioteca do Exército, 1971.

MATHIAS, Suzeley Kalil. A distensão no Brasil: o projeto militar (19731979). Campinas, SP: Papirus, 1995.

MATOS. Beatriz de Almeida. Os Mayoruna e a vigilância da fronteira. In: INSTITUTO SOCIOAMBIENTAL. Povos Indígenas no Brasil 2001/2005. São Paulo, 2006, p.443.

Os Mayoruna e o Exército brasileiro. Disponível em:

$<$ http://www.trabalhoindigenista.org.br/papers.asp $>$. Acesso em: 13 fev. 2007.

MAXIMIANO, Cesar Campiani. Neve, fogo e montanhas: a experiência brasileira de combate na Itália (1944/45). In: CASTRO, Celso; IZECKSOHN, Vitor; KRAAY, Hendrik. Nova história militar brasileira. Rio de Janeiro: FGV/Bom Texto, 2004. Cap. 13, p.343-364.

MÉLEGA, Roberta. Uma crônica da relação índios e militares na Cabeça de Cachorro (AM). Disponível em:

$<$ http://www. socioambiental.org/esp/indiosemilitares/robertamelega.htm $>$.

Acesso em: 13 fev. 2007.

MENDES, Fábio Faria. Encargos, privilégios e direitos: o recrutamento militar no Brasil nos séculos XVIII e XIX. In: CASTRO, Celso; IZECKSOHN, Vitor; KRAAY, Hendrik. Nova história militar brasileira. Rio de Janeiro: FGV/Bom Texto, 2004. Cap. 4, p.111-137. 
MIYAMOTO, Shiguenoli. Diplomacia e militarismo: o Projeto Calha Norte e a ocupação do espaço amazônico, Revista Brasileira de Ciência Política, n. 1, v. 1 p.145-163, mar. 1989.

Geopolítica e poder no Brasil. Campinas, SP: Papirus, 1995.

MONTEIRO, Deolinda Oliveira; QUEIROZ, Joselito Pereira de. Uma missão silenciosa na Amazônia. Revista Marítima Brasileira, Rio de Janeiro, v. 123, n. 10-12, p. 137-146, out./dez. 2003.

MORAIS, Fernando. Montenegro: as aventuras do Marechal que fez uma revolução nos céus do Brasil. São Paulo: Planeta, 2006.

MOSKOS, Charles. From Institution to Occupation: Trends in Military Organization. Armed Forces \& Society, p. 41-50, Fall 1977.

NASCIMENTO, Álvaro Pereira do. A ressaca da marujada: recrutamento e disciplina na Armada Imperial. Rio de Janeiro: Arquivo Nacional, 2001.

NASCIMENTO, Hilton S. A Terra Indígena Vale do Javari e a Fronteira Peruana. Disponível em:

$<$ http://www.trabalhoindigenista.org.br/papers.asp $>$.

Acesso em: 13 fev. 2007.

NEUMANN, Iver B.; HEIKKA, Henrikki. Grand Strategy, Strategic Culture, Practice: The Social Roots of Nordic Defence. Cooperation and Conflict: Journal of the Nordic International Studies Association, v. 10, n. 1, p. 5-23, 2005.

OBINO, José Luiz Feio. A Amazônia e a Marinha: suas necessidades de meios para o Terceiro Milênio - Uma reflexão. Revista Marítima Brasileira, Rio de Janeiro, v. 118, n. 4-6, p. 117-132, abr./jun. 1998a.

Considerações sobre a estrutura administrativa da Marinha na Amazônia. Revista Marítima Brasileira, Rio de Janeiro, v. 118, n. 10-12, p. 97-107, out./dez. 1998b.

OLIVEIRA, Eliézer Rizzo de. A Doutrina de Segurança Nacional: pensamento político e projeto estratégico. In: OLIVEIRA, Eliézer Rizzo de (Org.). Militares: pensamento e ação política. Campinas, SP: Papirus, 1987.

. De Geisel a Collor: Forças armadas, transição e democracia. Campinas, SP: Papirus, 1994.

Política de Defesa nacional e relações civis-militares no governo do presidente Fernando Henrique Cardoso. Caderno Premissas, Universidade Estadual de Campinas, Núcleo de Estudos Estratégicos, $\mathrm{n}$. 17-18, p. 37-68, maio 1998.

; SOARES, Samuel Alves. Forças Armadas, direção política e formato institucional. In: D'ARAUJO, Maria Celina e CASTRO, Celso. Democracia e Forças Armadas no Cone Sul. Rio de Janeiro: FGV, 2000.

Brasil. O Ministério da Defesa: a implantação da autoridade. In: Research and Education in Defense and Security Studies, Brasília, Brasil, 2002. Disponível em:

$<$ http://www3.ndu.edu/chds/redes2002/Documents/Papers/Track\%203.\%20 Defense\%20Policy\%20\%20Intelligence/22.Min.\%20of\%20Defense- 
\%20case\%20studies/Rizzo\%20de\%200liveiraFP.doc $>$. Acesso em: 24 set. 2004.

Democracia e Defesa Nacional: a criação do Ministério da Defesa na presidência de FHC. Barueri, SP: Manole, 2005.

PACHECO FILHO, René. Análise da Contribuição da Marinha para a Defesa da Amazônia. Revista Marítima Brasileira, Rio de Janeiro, v. 125, n. 10-12, p. 186-194, out./dez. 2005.

PASQUIS, Richard (Coord.). As Amazônias. Um mosaico de visões sobre a Região. Brasília, 2003. Disponível em:

$<$ http://www.amazonia.org.br/guia/detalhes.cfm?id=78645\&tipo=6\&cat id=3 8\&subcat id=154>. Acesso em: 19 set. 2003.

PEIXOTO, Antonio Carlos. Exército e política no Brasil: uma crítica dos modelos de interpretação. In: ROUQUIÉ, Alain (coord.). Os partidos militares no Brasil. Rio de Janeiro: Record, 1991. Cap. 2, p.27-42.

PEREIRA, Carlos; MUELLER, Bernardo. Uma teoria da preponderância do Poder Executivo. O sistema de comissões no Legislativo brasileiro. Revista Brasileira de Ciências Sociais, São Paulo, v. 15, n. 43, p. 45-67, Junho 2000.

PEREIRA, Mauro César Rodrigues. As Forças Armadas, a Marinha e o Ministério da Defesa. Pensamentos e relatos. Revista Marítima Brasileira, Rio de Janeiro, v. 122, n. 10-12, p.25-54, out./dez, 2002.

PETRÓ, Paulo Eduardo; PEREIRA JÚNIOR, Gilberto. Asas da Marinha na Amazônia. Revista Marítima Brasileira, Rio de Janeiro, v. 125, n. 10-12, p. 07-13, out./dez. 2005.

PINHEIRO, Álvaro de Souza. Guerrilha na Amazônia: uma experiência no passado, o presente e o futuro. Disponível em:

$<$ http://www.defesanet.com.br/toa/toa guerrilha 1.htm>. Acesso em: 11 dez. 2005.

PINTO, Renan Freitas. O Brasil mais esquecido. Teoria e Debate, São Paulo, n. 24, mar./abr./maio. 1994. Disponível em:

$<$ http://www2.fpa.org.br/portal/modules/news/article.php?storyid=1251>.

Acesso em: 12 fev. 2004.

PORCH, Douglas. Military "Culture" and the Fall of France in 1940. International Security, v. 24, n. 4, p.157-180, Spring, 2000.

POSEN, Barry R. The Sources of Military Doctrine: France, Britain, and Germany between the World Wars. Ithaca and London: Cornell University Press, 1984.

POTYGUARA, Moacyr Barcellos. Pelotão de Fronteira. Rio de Janeiro: Biblioteca do Exército, 2006.

PRICE, Richard; TANNENWALD, Nina. Norms and deterrence: The Nuclear and Chemical Weapons Taboos. In: KATZENSTEIN, Peter J. (Ed.). The Culture of National Security. Norms and Identity in World Politics. New York: Columbia University Press, 1996. Cap. 4, p. 114-152. 
PUNTONI, Pedro. A arte da guerra no Brasil: tecnologia e estratégias militares na expansão da fronteira da América portuguesa (1550-1700). In: CASTRO, Celso; IZECKSOHN, Vitor; KRAAY, Hendrik. Nova história militar brasileira. Rio de Janeiro: FGV/Bom Texto, 2004. Cap. 1, p.43-64.

QUEIROZ, Antônio Carlos. 1994. O direito das nações indígenas violados. Teoria e Debate, São Paulo, n. 24, mar./abr./maio. 1994. Disponível em: $<$ http://www2.fpa.org.br/portal/modules/news/article.php?storyid=1249>. Acesso em: 12 fev. 2004.

ROJAS ARAVENA, Francisco. Medidas de confianza mutua: um instrumento útil para la seguridad del hemisferio occidental. Revista Fuerzas Armadas y Sociedad, Año X, n. 03, p.1-11, Julio-Septiembre 1995.

ROUQUIÉ, Alain. Os processos políticos nos partidos militares do Brasil: estratégia de pesquisa e dinâmica institucional. In: ROUQUIÉ, Alain (coord.). Os partidos militares no Brasil. Rio de Janeiro: Record, 1991. Cap. 1, p.09-26.

SAHLINS, Marshall D. Ilhas de Historia. Rio de Janeiro: Jorge Zahar, 1990. . Cultura e Razão Prática. Rio de Janeiro: Jorge Zahar Ed., 2003.

SANTOS, Frederico Rodrigues dos Santos. Operações Ribeirinhas na Amazônia e o Batalhão de Fuzileiros Navais. Revista Marítima Brasileira, Rio de Janeiro, v. 114, n. 10-12, p. 151-167, out./dez. 1994.

SANTOS, Maria Helena de Castro. A nova missão das Forças Armadas Latino-Americanas no mundo pós-guerra fria: o caso do Brasil. Revista Brasileira de Ciências Sociais, São Paulo, v. 19, n. 54, p.115-129, fev. 2004.

SCHULTZ, John. O Exército na política: origens da intervenção militar (1850-1894). São Paulo: Edusp, 1994.

SERVIÇO DE RELAÇÕES PÚBLICAS DA MARINHA. A Marinha e a Política de Defesa Nacional (Parte II). Revista Marítima Brasileira, Rio de Janeiro, v. 118, n. 1-3, p. 115-127, jan./mar. 1998.

SILVA, Roberto Gama. Amazônia Brasileira. Revista Marítima Brasileira, Rio de Janeiro, v. 120, n. 1-3, p. 89-107, jan./mar. 2000.

A Amazônia, sua invasão, seu desmatamento e queimadas. Revista Marítima Brasileira, Rio de Janeiro, v. 121, n. 10-12, p. 95-103, out./dez. 2001.

A Amazônia, o Brasil e a dissuasão necessária. Revista Marítima Brasileira, Rio de Janeiro, v. 124, n. 7-9, p. 73-75, jul./set. 2004.

SILVEIRA, Argeu Cirne da. Águia ferida na rota do Araguaia. 2. ed. Rio de Janeiro: Revista Aeronáutica, 1987.

SNYDER, Jack L. The Ideology of Offensive: Military Decision Making and the Disasters of 1914. Ithaca, New York: Cornell University Press, 1984.

Anarchy and Culture: Insigts from the Antropology of War. International Organization,v. 56, n. 1, p. 07-45, Winter 2003. 
SOARES, Glauco Ary Dillon; D'Araujo Maria Celina; CASTRO, Celso. A volta aos quartéis: a memória militar sobre a abertura. Rio de Janeiro: Relume-Dumará, 1995.

SOARES, Samuel Alves. De autonomias y controles: fuerzas armadas y sistema político em Brasil (1995-2002). Revista Fuerzas Armadas e Sociedad. FLACSO-CHILE, año 18, n. 3/4, p.53-81, jul./dic., 2004.

SODRÉ, Nelson Werneck. História Militar do Brasil. Rio de Janeiro: Civilização Brasileira, 1968.

SOETERS, J.; RECHT, R. Culture and Discipline in Military Academies: An International Comparison. Journal of Political and Military Sociology, n. 26, p. 169- 189, Winter 1998.

SOUZA, Adriana Barreto de. A serviço de Sua Majestade: a tradição militar portuguesa na composição do generalato brasileiro (1837-50). In: CASTRO, Celso; IZECKSOHN, Vitor; KRAAY, Hendrik. Nova história militar brasileira. Rio de Janeiro: FGV/Bom Texto, 2004. Cap. 6, p. $159-178$.

STEPAN, Alfred. Os militares: da abertura à Nova República. Rio de Janeiro: Paz e Terra, 1986.

STUDART, Hugo. A lei da selva: estratégias, imaginário e discurso dos militares sobre a guerrilha do Araguaia. São Paulo: Geração Editorial, 2006.

TREVISAN, Leonardo. O que todo cidadão precisa saber sobre o pensamento militar brasileiro. São Paulo: Editora Global, 1985.

. O que todo cidadão precisa saber sobre a instituição militar e o Estado brasileiro. São Paulo: Editora Global, 1987.

TUCÍDIDES. The History of the Peloponnesian War. Project Gutenberg eBooks, 2004. Disponível em:

$<$ http://www.dominiopublico.gov.br/download/texto/gu007142.pdf>.

Acesso em: 19 jan. 2007.

VALDENICE. Infantaria do Futuro. Aerovisão. Brasília, DF, n. 206, abr./jun. 2003.

VERDE OLIVA. Nossa Força na Amazônia. Verde Oliva. Brasília, DF, ano XXX, n. 176, out./nov./dez. 2002. Disponível em:

$<$ http://www.exercito.gov.br/VO/176/am.htm>. Acesso em: 21 fev. 2007.

. Amazônia - Pelotões Especiais de Fronteira. Verde Oliva. Brasília, ano XXXII, n. 189, jul./ago./set. 2006. Disponível em:

$<$ http://www.exercito.gov.br/VO/189/amazonia.htm>. Acesso em: $20 \mathrm{fev}$. 2007.

VIANA, Oliveira. Populações Meridionais do Brasil. Rio de Janeiro: Nova Aguilar, 2002. (Coleção Intérpretes do Brasil, v. 1).

VIDIGAL, Armando Amorim Ferreira. Reflexões adicionais sobre uma nova concepção estratégica para o Brasil - um debate necessário. Revista Marítima Brasileira, Rio de Janeiro, v. 110, n. 7-9, p. 49-61, jul./set. 1990 
A internacionalização da Amazônia. Revista Marítima Brasileira, Rio de Janeiro, v. 122, n. 4-6, p. 81-98, abr. jun. 2002.

Record, 2006.

et al. Amazônia azul: o mar que nos pertence. Rio de Janeiro:

VILLA, Rafael Antonio Duarte. A Antártida no Sistema Internacional: análise das relações entre os atores estatais e não-estatais com base na perspectiva da questão ambiental. São Paulo: Hucitec, 2004.

WENDT, Alexander. Social Theory of International Politics. Cambridge:

Cambridge University Press, 2005.

YANOW, Dvora. Silences in Public Policy Discourse: Organizational and Policy Myths. Journal of Public Administration Research and Theory 2, p. 399-423, 1992.

Seeing Organizational Learning: A Cultural View. Organization. London, Thousand Oaks-CA, New Delhi: Sage, v. 7, p. 247-268, 2000.

ZAVERUCHA, Jorge. Democracia e Ministério da Defesa Brasileiro. Research and Education in Defense and Security Studies, Santiago, Chile, 2003. Disponível em:

$<$ http://www.seguridadregional-fes.org/cgi-bin/showdocs.asp?ISBN=0907>. Acesso em: 10 jan. 2007.

\section{Artigos publicados na imprensa}

CANTANHÊDE, Eliane. O fator Guiana. Folha de São Paulo, São Paulo, 16 de mar. 2007. Disponível em:

$<$ http://www1.folha.uol.com.br/fsp/opiniao/fz1603200704.htm>.

Acesso em: 16 mar. 2007.

CARNEIRO, Mariana. Eles já estão entre nós. Instituições estrangeiras fincam bandeira em território nacional usando índios. Jornal do Brasil, Rio de Janeiro, p. A6, 28 de jan. 2007a. de fev. 2007b.

Estão vendendo o país. Jornal do Brasil, Rio de Janeiro, p. A7, 02

CAVOUR, Clara; EXMAN, Fernando; Karla Correia. Governo não controla ONGs. Organizações atuam como instrumento político de grupos internacionais sob o disfarce da defesa do meio ambiente. Jornal do Brasil, Rio de Janeiro, p. A2 - A3, 30 de jan. 2007.

GODOY, Roberto. Evo quer aviões negados a Chávez. O Estado de $S$. Paulo, São Paulo, 15 de maio 2007. Disponível em:

$<$ http://www.fab.mil.br/imprensa/enotimp/enotimp capa.htm>. Acesso em: 15 maio. 2007.

MANSO, Bruno Paes. Cidadãos da Selva. Veja, Cidades, Especial Amazônia. Disponível em: $<$ http://veja.abril.uol.com.br/amazonia/p 058.html>. Acesso em: 10 jan. 2005.

NUNES, Augusto. Americanos lideram invasão estrangeira. Jornal do Brasil, Rio de Janeiro, p. A2, 28 de jan. 2007. 
PEREIRA, Daniel. Amazônia dividida em lotes. Jornal do Brasil, Rio de Janeiro, p. A2, 31 de jan. 2007a.

; CARNEIRO, Mariana. Reação às florestas privatizadas. Jornal do Brasil, Rio de Janeiro, p. A7, 01 de fev. 2007b.

\section{Conferências, Discursos e Depoimentos.}

CAMBESES JÚNIOR, Manuel. A Defesa Aeroespacial da Região Amazônica. Conferência. In: Seminário sobre a Amazônia. Rio De Janeiro, Escola Superior de Guerra, 2007.

DENYS, Rubens Bayma. Rubens Bayma Denys: depoimento [13 mar. 1998]. Entrevistadores: Celso Castro e Maria Celina D’Araujo. Entrevista concedida para o projeto Democracia e Forças Armadas no Brasil e nos países do Cone Sul.

LAMPREIA, Luiz Felipe. 1995. O Brasil o contexto mundial: uma visão do Itamaraty. Conferência. In: II Encontro Nacional de Estudos Estratégicos, São Paulo, Universidade de São Paulo, 1995. ARAUJO, Braz (Coord.). Anais... São Paulo: NAIPPE/USP, 1996, v. 5, p. 17-34.

LOPES, Alcedir Pereira. Alcedir Pereira Lopes: depoimento [23 nov. 2001]. Entrevistador: Celso Castro. Entrevista concedida para o projeto Os Militares e a Amazônia: Desenvolvimento Nacional, Soberania e Novos Cenários Estratégicos.

LUCENA. Zenildo Zoroastro. Entrevista. Verde Oliva. Brasília, ano XXVII, n. 161, maio/jun. 1998. Disponível em:

$<$ http://www.exercito.gov.br/VO/161/entrevis.htm>. Acesso em: $16 \mathrm{fev}$. 2007.

PANNUNZIO, Antônio Carlos (PSDB-SP). Antônio Carlos Pannunzio: depoimento [23 set. 1999]. Entrevistadora: Adriana A. Marques. Brasília, 1999. 1 fita cassete (60 min). Entrevista concedida para elaboração de dissertação de mestrado da entrevistadora.

PINTO, Marluce. Pronunciamentos. In: BRASIL. Congresso. Senado. Diário do Senado Federal, 02 mar. 1999. Disponível em:

$<$ http://www.senado.gov.br/sf/atividade/Pronunciamento/detTexto.asp?t=23 8493 >. Acesso em: 15 fev. 2005.

SIRKIS, Alfredo (PV). Alfredo Sirkis: depoimento [jun. 1999]. Entrevistadora: Adriana A. Marques. Rio de Janeiro, 1999. 1 fita cassete (60 min). Entrevista concedida para elaboração de dissertação de mestrado da entrevistadora.

TAVEIRA, Nelson de Souza. Nelson de Souza Taveira: depoimento [24 set. 1999]. Entrevistadora: Adriana A. Marques. Brasília, 1999. 1 fita cassete (60 min). Entrevista concedida para a elaboração de dissertação de mestrado da entrevistadora.

VIDIGAL, Armando Amorim Ferreira. Armando Amorim Ferreira Vidigal: depoimento [27 jan. 2007]. Entrevistadora: Adriana A. Marques. Rio de 
Janeiro, 2007. 2 fitas cassete $(60 \mathrm{~min})$. Entrevista concedida para a elaboração de tese de doutorado da entrevistadora.

\section{Dissertações, Monografias e Teses.}

ALMEIDA, Manoel Morata. Áreas sensíveis na Região Norte e os llícitos: contrabando de armas e tráfico de drogas. 1998. Monografia (Curso de Política, Estratégia e Alta Administração do Exército) - Escola de Comando e Estado-Maior do Exército - ECEME, Rio de Janeiro, 1998.

AMARAL, Paulo César Carneiro do. O Projeto Calha Norte: importância para a região amazônica e seus reflexos na segurança nacional. 1990. Monografia (Curso de Política, Estratégia e Alta Administração do Exército) - Escola de Comando e Estado-Maior do Exército - ECEME, Rio de Janeiro, 1990.

ANDRADE, Karenina Vieira. O Calha Norte e suas transformações. 2003. Dissertação (Mestrado em Antropologia) - Instituto de Ciências Sociais, Universidade de Brasília - UNB, Brasília, 2003.

ASSIS, Francisco Florêncio de. Conquista e manutenção da soberania nacional sobre a Amazônia. Monografia (Curso de Comando e EstadoMaior da Aeronáutica) - Escola de Comando e Estado-Maior da Aeronáutica - ECEMAR, Rio de Janeiro, 1982.

BELLINATI, Newton. Obras na Região Amazônica: óbices e Sugestões. 1998. Monografia (Curso de Política, Estratégia e Alta Administração do Exército) - Escola de Comando e Estado-Maior do Exército - ECEME, Rio de Janeiro, 1998.

BENSUSAN, Henrique Filho. Sugestões para uma Estratégia na Amazônia no século XXI. 2001. Monografia (Curso de Política, Estratégia e Alta Administração do Exército) - Escola de Comando e Estado-Maior do Exército - ECEME, Rio de Janeiro, 2001.

BEZERRA, Marconi dos Reis. Uma proposta de integração do Sistema Estratégico de Guerra Eletrônica com o Sistema de Vigilância da Amazônia. 1998. Monografia (Curso de Política, Estratégia e Alta Administração do Exército) - Escola de Comando e Estado-Maior do Exército - ECEME, Rio de Janeiro, 1998.

BOAVENTURA, Marco Aurélio. Evolução da doutrina militar brasileira no século XX. 2001. Monografia (Curso de Política, Estratégia e Alta Administração do Exército) - Escola de Comando e Estado-Maior do Exército - ECEME, Rio de Janeiro, 2001.

BRAGA, Yoney. Aspectos estratégicos da bacia amazônica, sob o ponto de vista naval. 1972. Monografia (Curso de Política e Estratégias Marítimas) Escola de Guerra Naval - EGN, Rio de Janeiro, 1972.

BRANCO, Walter Romero Castelo. Amazônia: a crise de integridade do Estado. 2001. Monografia (Curso de Política, Estratégia e Alta Administração do Exército) - Escola de Comando e Estado-Maior do Exército - ECEME, Rio de Janeiro, 2001.

CARVALHO, Aildon Dornellas de. Os problemas da fronteira norte e a 
participação da $F A B$. Monografia (Curso de Comando e Estado-Maior da Aeronáutica) - Escola de Comando e Estado-Maior da Aeronáutica ECEMAR, Rio de Janeiro, 1975.

COSTA, Aloísio Dias da. A Força Aérea Brasileira no Projeto Calha Norte: proposta de incremento da participação. Monografia (Curso de Comando e Estado-Maior da Aeronáutica) - Escola de Comando e Estado-Maior da Aeronáutica - ECEMAR, Rio de Janeiro, 1989.

COSTA, Eugênio Pacelli Lazzarotti Diniz. O Projeto Calha Norte: Antecedentes Políticos. 1994. Dissertação (Mestrado em Ciência Política) Faculdade de Filosofia Letras e Ciências Humanas, Universidade de São Paulo - USP, São Paulo, 1994.

CRUZ, Osvaldo Guimarães da. A COMARA, sua constituição e importância na Amazônia e na Segurança Nacional. Monografia (Curso de Comando e Estado-Maior da Aeronáutica) - Escola de Comando e Estado-Maior da Aeronáutica - ECEMAR, Rio de Janeiro, 1975.

DESTRO, Marcio Antonio. Soberania no Rio Branco e a demarcação da terra indígena Raposa Serra do Sol. 2006. Dissertação (Mestrado em Relações Internacionais) - Instituto de Relações Internacionais, Universidade de Brasília - UNB, Brasília, 2006.

DOVAL, Eduardo Luis. Reflexos nos processos de integração regional (MERCOSUL) no âmbito militar. 1997. Monografia (Curso de Política, Estratégia e Alta Administração do Exército) - Escola de Comando e Estado-Maior do Exército - ECEME, Rio de Janeiro, 1997.

FACIOLI, José Mário. A Integração Sul-americana. 1998. Monografia (Curso de Política, Estratégia e Alta Administração do Exército) - Escola de Comando e Estado-Maior do Exército - ECEME, Rio de Janeiro, 1998.

FALCONI, Paulo. FAB: modernizando-se pelo SIVAM? 2004. Dissertação (Mestrado em História Política) - Faculdade de História, Direito, Relações Internacionais e Serviço Social, Universidade Estadual Paulista - UNESP, Franca, SP, 2004.

FÁZIO, Ednéia. Formação e perfil dos alunos da Escola Preparatória de Cadetes do Exército (1990-2000). 2003. Dissertação (Mestrado em História e Cultura Política) - Faculdade de História, Direito e Serviço Social, Universidade Estadual Paulista - UNESP, Franca, SP, 2003.

FLEURY, Sérgio de Souza; MARQUES, Gustavo Adolfo Torres. Segurança Hemisférica em face da OEA/TIAR. 1994. Monografia (Curso de Política, Estratégia e Alta Administração do Exército) - Escola de Comando e Estado-Maior do Exército - ECEME, Rio de Janeiro, 1994.

FREDERICO, Ivair. Globalização e os Reflexos Para a Expressão Militar. 2001. Monografia (Curso de Política, Estratégia e Alta Administração do Exército) - Escola de Comando e Estado-Maior do Exército - ECEME, Rio de Janeiro, 2001.

FREITAS, Jairo de Castro. O papel do exército na sociedade brasileira no próximo século. 1997. Monografia (Curso de Política, Estratégia e Alta 
Administração do Exército) - Escola de Comando e Estado-Maior do Exército - ECEME, Rio de Janeiro, 1997.

FREITAS, José Luiz. Uma nova visão da cultura no Exército. 1998. Monografia (Curso de Política, Estratégia e Alta Administração do Exército) - Escola de Comando e Estado-Maior do Exército - ECEME, Rio de Janeiro, 1998.

FUCCILLE, Luis Alexandre. Democracia e questão militar: a criação do Ministério da Defesa no Brasil. Campinas, SP. 2006. Tese (Doutorado em Ciências Sociais) - Instituto de Filosofia e Ciências Humanas, Universidade Estadual de Campinas, UNICAMP, Campinas, SP, 2006.

FURNIEL, Ana Cristina da Matta. Amazônia - A ocupação de um espaço: Internacionalização $x$ Soberania Nacional. Rio de Janeiro. 1993. Dissertação (Mestrado em Relações Internacionais) - Instituto de Relações Internacionais, Pontifícia Universidade Católica do Rio de Janeiro - PUCRJ, Rio de Janeiro, 1993.

GONÇALVES, Joaquim Gabriel Alonso. Integração militar regional: uma manobra da diplomacia militar. 1997. Monografia (Curso de Política, Estratégia e Alta Administração do Exército) - Escola de Comando e Estado-Maior do Exército - ECEME, Rio de Janeiro, 1997.

GUIMARÃES, Nelson. A FAB na Amazônia. (Curso de Comando e EstadoMaior da Aeronáutica) - Escola de Comando e Estado-Maior da Aeronáutica - ECEMAR, Rio de Janeiro, 1980.

HEIMO, André da Silva Guimarães de Luna. A implantação do MERCOSUL e seus reflexos para a segurança externa do Brasil. 1999. Monografia (Curso de Política, Estratégia e Alta Administração do Exército) - Escola de Comando e Estado-Maior do Exército - ECEME, Rio de Janeiro, 1999.

HOLLANDA, Bernardo Augusto Cunha De. A presença militar norteamericana na Amazônia. 2004. Monografia (Curso de Política e Estratégias Marítimas) - Escola de Guerra Naval - EGN, Rio de Janeiro, 2004.

JANUÁRIO, Rubens Alberto Rodrigues. As fortalezas do Tratado de Madri e os pelotões de fronteira do Projeto Calha Norte na região do Alto Rio Negro: soberania em duas épocas. 1996. Monografia (Curso de Política, Estratégia e Alta Administração do Exército) - Escola de Comando e Estado-Maior do Exército - ECEME, Rio de Janeiro, 1996.

KUHLMANN, Paulo Roberto Loyolla. O serviço militar, democracia e defesa nacional: razões da permanência do modelo de recrutamento no Brasil. 2001. Dissertação (Mestrado em Ciência Política) - Departamento de Ciência Política, Faculdade de Filosofia, Letras e Ciências Humanas, Universidade de São Paulo - USP, São Paulo, 2001.

LIMA, Reinaldo Nonato de Oliveira. Exército Brasileiro: uma postura para o terceiro milênio. 1999. Monografia (Curso de Política, Estratégia e Alta Administração do Exército) - Escola de Comando e Estado-Maior do Exército - ECEME, Rio de Janeiro, 1999.

MADUREIRA, Mário Matheus de Paula. O Brasil e a Fronteira Norte: política e estratégia. 2000. Monografia (Curso de Política, Estratégia e Alta 
Administração do Exército) - Escola de Comando e Estado-Maior do Exército - ECEME, Rio de Janeiro, 2000.

MAGLUF, Alei Salim. A Amazônia: novas ameaças e seus reflexos para o Exército Brasileiro no próximo quarto de século. 2000. Monografia (Curso de Política, Estratégia e Alta Administração do Exército) - Escola de Comando e Estado-Maior do Exército - ECEME, Rio de Janeiro, 2000.

MARQUES, Adriana A. Concepções de Defesa Nacional no Brasil : 19501996. 2001. Dissertação (Mestrado em Ciência Política) - Instituto de Filosofia e Ciências Humanas, Universidade Estadual de Campinas UNICAMP, Campinas, SP, 2001.

MENINÉA, Vitor Hugo. A globalização e seus reflexos nos campos do poder. 2001. Monografia (Curso de Política, Estratégia e Alta Administração do Exército) - Escola de Comando e Estado-Maior do Exército - ECEME, Rio de Janeiro, 2001.

NASCIMENTO, Durbens Martins. 2005. Projeto Calha Norte: Política de Defesa Nacional e Segurança Hemisférica na Governança Contemporânea. Tese (Doutorado em Desenvolvimento Sustentável do Trópico Úmido) Núcleo de Altos Estudos Amazônicos, Universidade Federal do Pará UFPA, Belém, 2005.

OLIVEIRA, Arnaldo Braga de. 1972. A ocupação da Amazônia brasileira. Monografia (Curso de Política e Estratégias Marítimas) - Escola de Guerra Naval - EGN, Rio de Janeiro, 1972.

OLIVEIRA, Juliano de. Força Aérea Brasileira: doutrina e estrutura da geopolítica (do Prata à Amazônia - 1964/2003). 2005. Dissertação (Mestrado em História e Cultura Política) - Faculdade de História, Direito e Serviço Social, Universidade Estadual Paulista - UNESP, Franca, SP, 2005.

PAIVA, Luiz Eduardo Rocha. Dissuasão e Presença: reflexões para a Força Terrestre o próximo quarto de século. Monografia (Curso de Política, Estratégia e Alta Administração do Exército) - Escola de Comando e Estado-Maior do Exército - ECEME, Rio de Janeiro, 2000.

PERES, Sidnei Clemente. Cultura, política e identidade na Amazônia: o associativismo indígena no Baixo Rio Negro. 2003. Tese (Doutorado em Antropologia) - Instituto de Filosofia e Ciências Humanas, Universidade Estadual de Campinas - UNICAMP, Campinas, SP, 2003.

PIMENTA, Fernando Jacques de Magalhães. The Treaty for Amazonian Cooperation an Analysis of the Brazilian Proposal in the Light of Brazil's Regional and International Constraints. 1982. Dissertação (Master of Arts). School of Arts and Sciences, George Washington University, Washington, DC, 1982.

PLIOPAS, Celso. A FAB e a integração do homem amazônico. Monografia (Curso de Comando e Estado-Maior da Aeronáutica) - Escola de Comando e Estado-Maior da Aeronáutica - ECEMAR, Rio de Janeiro, 1975.

RIBAS, João Wayner da Costa. A narcoguerrilha na Colômbia: reflexos para o Brasil nos campos do poder nacional. 2001. Monografia (Curso de 
Política, Estratégia e Alta Administração do Exército) - Escola de Comando e Estado-Maior do Exército - ECEME, Rio de Janeiro, 2001.

ROSSI, Isabel Cristina. SIVAM: um caso de dependência tecnológica 19901996. 2003. Dissertação (Mestrado em Sociologia) Faculdade de Ciências e Letras, Universidade Estadual Paulista "Júlio de Mesquita", Araraquara, SP, 2003.

SERRATINE, Edison Norberto Sanchotene. Tiro-de-Guerra em áreas carentes: fator de ocupação territorial. 1997. Monografia (Curso de Política, Estratégia e Alta Administração do Exército) - Escola de Comando e Estado-Maior do Exército - ECEME, Rio de Janeiro, 1997.

SILVA, Marcelle Ivie da Costa. Amazônia e Política de Defesa no Brasil. Campinas, SP. 2004. Dissertação (Mestrado em Relações Internacionais). Instituto de Filosofia e Ciências Humanas, Universidade Estadual de Campinas, Campinas, SP, 2004.

SILVA e LUNA, Joaquim. Uma Concepção do Exército Brasileiro para a CEA do Século XXI. 1998. Monografia (Curso de Política, Estratégia e Alta Administração do Exército) - Escola de Comando e Estado-Maior do Exército - ECEME, Rio de Janeiro, 1998.

SILVA FILHO, Antonio Rodrigues da. Projeções de Forças: uma reposta as incertezas do próximo século. 1997. Monografia (Curso de Política, Estratégia e Alta Administração do Exército) - Escola de Comando e Estado-Maior do Exército - ECEME, Rio de Janeiro, 1997.

SILVEIRA, Cláudio de Carvalho. A Formação dos oficiais da Marinha do Brasil: educação, profissão, pensamento estratégico (1978-2001). 2002. Tese (Doutorado em Ciências Sociais) - Instituto de Filosofia e Ciências Humanas, Universidade Estadual de Campinas - UNICAMP, Campinas, SP, 2002.

SOARES, Samuel Alves. Militares e pensamento político: análise de monografias da Escola de Comando e Estado Maior do Exército (19851993). 1994. Dissertação (Mestrado em Ciência Política) - Departamento de Ciência Política, Faculdade de Filosofia, Letras e Ciências Humanas, Universidade de São Paulo - USP, São Paulo, 1994.

Forças Armadas e sistema político na democracia. 2000. Tese (Doutorado em Ciência Política). Departamento de Ciência Política, Faculdade de Filosofia, Letras e Ciências Humanas, Universidade de São Paulo - USP, São Paulo, 2000.

SOUTO, Cláudio Heráclito; ALVES, M. da Penha; ASSIS, Paulo Roberto Correia. Ameaças à soberania nacional na Amazônia, hipóteses de guerra, estratégias para a defesa da região. 1990. Monografia (Curso de Política, Estratégia e Alta Administração do Exército) - Escola de Comando e Estado-Maior do Exército - ECEME, Rio de Janeiro, 1990.

SOUZA JÚNIOR, José de. A influência da Era Vargas na Aeronáutica. Monografia (Curso de Comando e Estado-Maior da Aeronáutica) - Escola de Comando e Estado-Maior da Aeronáutica - ECEMAR, Rio de Janeiro, 2004. 
STEVAUX, João Batista. Missão dos Elementos de Fronteira: manutenção da integridade territorial ou vivificação da faixa de fronteira. Monografia (Curso de Altos Estudos Militares) - Escola de Comando e Estado-Maior do Exército - ECEME, Rio de Janeiro, 1996.

TAKAHASHI, Emília Emi. Homens e mulheres em campo: um estudo sobre a formação da identidade militar. 2002. Tese (Doutorado em Pedagogia) Faculdade de Educação, Universidade Estadual de Campinas - UNICAMP, Campinas, SP, 2002.

TORRECUSO, Paolo Alves Dantas. O Tratado de Cooperação Amazônica e a Organização do Tratado de Cooperação Amazônica: análise da criação evolução e eficácia de um regime internacional. 2004. Dissertação (Mestrado em Relações Internacionais), Instituto de Relações Internacionais, Universidade de Brasília, Brasília, DF, 2004.

TROMPWSKI, Júlio Melchior Von. Preparo e emprego da Força Aérea no ambiente amazônico - uma doutrina a ser desenvolvida. Monografia (Curso de Comando e Estado-Maior da Aeronáutica) - Escola de Comando e Estado-Maior da Aeronáutica - ECEMAR, Rio de Janeiro, 1990.

\section{Documentos}

ALMEIDA, Perpétua. Voto em separado. In: BRASIL, Congresso. Câmara dos Deputados. Comissão de Relações Exteriores e Defesa Nacional. Relatório da Comissão Externa destinada a avaliar a situação da demarcação da terra indígena Raposa Serra do Sol, no estado de Roraima, 06 abr. 2004. (Relator: Lindberg Farias). Disponível em: $<$ http://www.camara.gov.br/sileg/integras/210268.pdf >. Acesso em: 14 jan. 2005.

BRASIL. Decreto n. 73.530, de 22 de janeiro de 1974. Dispõe sobre as Prefeituras de Aeronáutica, aprova seu Regulamento e dá outras providências. Disponível em:

$<$ http://www6.senado.gov.br/legislacao/ListaPublicacoes. action?id=122092> . Acesso em: 19 dez. 2006.

Decreto n. 88.134 de 01 de março de 1983. Cria o Sétimo Comando Aéreo Regional e dá outras providências. Disponível em: $<$ http://www6.senado.gov.br/legislacao/ListaPublicacoes. action?id=127719> . Acesso em: 19 dez. 2006.

Lei n. 7.565, de 19 de dezembro de 1986. Código Brasileiro de Aeronáutica. Disponível em:

$<$ https://www.planalto.gov.br/ccivil 03/Leis/L7565.htm>. Acesso em: $13 \mathrm{dez}$. 2005.

1996.

Presidência da República, Política de Defesa Nacional, Brasília,

Exército Brasileiro. Estado-Maior do Exército. Instruções Provisórias IP 72-20 - O Batalhão de Infantaria de Selva, 1997.

. Lei n. 9.614, de 05 de março de 1998. Altera a Lei n. 7.565, de 19 de dezembro de 1986, para incluir hipótese de destruição de aeronave. Disponível em: <https://www.planalto.gov.br/ccivil 03/Leis/L9614.htm>. 
Acesso em: 13 dez. 2005.

Ministério da Defesa. Exército Brasileiro. Estado-Maior do Exército.

Manual de Campanha C 5-1 - Emprego da Engenharia, 3. ed., 1999a.

Medida Provisória n. 1.799-6, de 10 de junho de 1999b. Altera dispositivos da Lei n. 9.649, de 27 de maio de 1998, que dispõe sobre a organização da Presidência da República e dos Ministérios, e dá outras providências.

Lei Complementar n. 97, de 09 de junho de 1999c. Dispões sobre as normas gerais para a organização, o preparo e o emprego das Forças Armadas. Disponível em:

$<$ http://www.planalto.gov.br/CCIVIL/Leis/LCP/Lcp97.htm>. Acesso em: 29 jul. 1999.

Constituição (1988). Emenda Constitucional n. 23, de 02 de setembro de 1999d. Altera os arts. 12, 52, 84, 91, 102 e 105 da Constituição Federal (criação do Ministério da Defesa). Disponível em: $<$ http://www.planalto.gov.br/ccivil $03 /$ Constituicao/Emendas/Emc/emc23.ht $\mathrm{m}>$.

Acesso em: 03 out. 1999.

Estado-Maior do Exército. Portaria n.020, de 02 de abril de 2003a. Aprova a Diretriz do Exército Brasileiro com as comunidades indígenas. Disponível em: <http://www.socioambiental.org/website/noticias/indios/portaria.html>. Acesso em: 17 nov. 2006.

Ministério da Defesa. Exército Brasileiro. Gabinete do Comandante. Portaria n. 580, de 08 de outubro de 2003b. Aprova as normas para a Concessão da Medalha de Serviço Amazônico. Disponível em: <http://www.sgex.eb.mil.br>. Acesso em: 21 jan. 2006.

Decreto n. 4.735, de 11 de junho de 2003c. Aprova a Estrutura Regimental e o Quadro Demonstrativo dos Cargos em Comissão do GrupoDireção e Assessoramento Superiores - DAS, das Funções Gratificadas FG, das Gratificações de Exercício em Cargo de Confiança, das Gratificações de Representação pelo Exercício de Função e das Gratificações de Representação - GR do Ministério da Defesa, e dá outras providências. Disponível em:

$<$ http://www.planalto.gov.br/ccivil 03/decreto/2003/D4735.htm>. Acesso em: 15 jul. 2004.

Decreto n. 5.301, de 09 de dezembro de 2004a. Regulamenta o disposto na Medida Provisória n. 228, de 09 de dezembro de 2004, que dispõe sobre a ressalva prevista na parte final do disposto no inciso XXXIII do art. 5. da Constituição, e dá outras providências. Disponível em:

$<$ http://www.planalto.gov.br/ccivil 03/ Ato20042006/2004/Decreto/D5301.ht m>. Acesso em: 15 jan. 2007.

Decreto n. 5.144, de 16 de julho de 2004b. Regulamenta os $\S \S 1$, 2. e 3. do art. 303 da Lei n. 7.565, de 19 de dezembro de1986, que dispõe sobre o Código Brasileiro de Aeronáutica, no que concerne às aeronaves 
hostis ou suspeitas de tráfico de substâncias entorpecentes e drogas afins. Disponível em:

<http://www.planalto.gov.br/ccivil 03/ Ato20042006/2004/Decreto/D5144.ht m >. Acesso em: 03 set. 2004.

Memorando de Entendimento Tripartite entre o Ministério da Defesa e o Ministério da Justiça da República Federativa do Brasil, o Ministério da Defesa Nacional da República da Colômbia e o Ministério da Defesa da República do Peru, para coibir as Atividades llícitas nos Rios Fronteiriços Comuns, de 11 de fevereiro de 2004c.

Lei n. 11.181, de 26 de setembro de 2005a. Autoriza o Poder Executivo a doar 6 (seis) aeronaves T-25 à Força Aérea Boliviana e 6 (seis) à Força Aérea Paraguai. Disponível em:

<http://www.planalto.gov.br/ccivil 03/ Ato2004-2006/2005/Lei/L11181.htm. Acesso em: 14 fev. 2007.

Acordo de Cooperação Mútua entre o Governo da República Federativa do Brasil e o Governo da República Bolivariana da Venezuela para combater o Tráfego de Aeronaves Envolvidas em Atividades llícitas Transnacionais, de dezembro de 2005b.

Decreto n. 5.484, de 30 de junho de 2005c. Aprova a Política de Defesa Nacional, e dá outras providências. Disponível em: $<$ https://www.planalto.gov.br/ccivil 03/ Ato2004-

2006/2005/Decreto/D5484.htm>. Acesso em: 21 jan. 2006.

. Ministério da Defesa. Exército Brasileiro. Estado-Maior do Exército. Concepção Estratégica do Exército (SIPLEx-4). Disponível em:

$<$ http://www.exar.eb.mil.br/legisla/DIVERSOS/SIPLEx\%20(27\%20Jun\%200 2).htm >. Acesso em: 21 jan. 2006a.

Decreto n. 5.752, de 12 de abril de 2006b. Promulga o Memorando de Entendimento entre os Governos da República Federativa do Brasil e da República do Peru sobre Cooperação em Matéria de Proteção e Vigilância da Amazônia, celebrado em Lima, em 25 de agosto de 2003. Disponível em:<https://www.planalto.gov.br/ccivil/ Ato20042006/2006/Decreto/D5752. htm>. Acesso em: 15 fev. 2007.

Decreto n. 5.815, de 26 de junho de 2006c. Promulga o Acordo de Cooperação Mútua entre o Governo da República Federativa do Brasil e o Governo da República da Colômbia para o Combate ao Tráfego de Aeronaves Envolvidas com Atividades llícitas Transnacionais, celebrado em Cartagena de Índias, em 7 de novembro de 1997. Disponível em: http://www2.mre.gov.br/dai/b colo 91 4505.htm. Acesso em: 14 fev. 2007.

Lei n. 11.283, de 23 de fevereiro de 2006d. Autoriza o Poder Executivo a doar 5 (cinco) aeronaves C-91A à Força Aérea Equatoriana. Disponível em:

http://www.planalto.gov.br/ccivil 03/ Ato2004-2006/2006/Lei/L11283.htm.

Acesso em: 14 fev. 2007.

Ministério da Defesa. Secretaria de Política, Estratégia e Assuntos

Internacionais. Doutrina Militar de Defesa - MD51-M-04. 2. ed., 2007a. 
Acordo Quadro sobre Cooperação em Matéria de Defesa entre o Governo da República Federativa do Brasil e o Governo da República do Peru. Disponível em: http://www2.mre.gov.br/dai/b peru 173 5839.htm. Acesso em: 14 fev. 2007b.

Memorando de Entendimento entre o Ministério da Defesa da República Federativa do Brasil e o Ministério da Defesa da República da Colômbia sobre Cooperação em Relação a Matérias de Defesa. Disponível em: http://www2.mre.gov.br/dai/b colo 95 5103.htm. Acesso em: 15 fev. 2007c.

Acordo de Cooperação Mútua entre o Governo da República Federativa do Brasil e o Governo da República da Bolívia para Combater o Tráfego de Aeronaves Envolvidas com Atividades llícitas Transnacionais. Disponível em: http://www2.mre.gov.br/dai/b boli 232 5679.htm. Acesso em: 14 fev. 2007d.

COLIGAÇÃO A FORÇA DO POVO. Programa de governo. Disponível em: http://www.estadao.com.br/ext/eleicoes2006/integra1 lula.htm. Acesso em: 15 nov. 2006.

COLIGAÇÃO GRANDE ALIANÇA. Programa do governo José Serra: trabalho e progresso para todos. Disponível em:

$<$ www.estadao.com.br/ext/eleicoes2002/programa ser/index.htm>. Acesso em: 29 jun. 2005.

COLIGAÇÃO LULA PRESIDENTE. Programa de Governo da Coligação Lula Presidente. Disponível em:

$<$ www.estadao.com.br/ext/eleicoes2002/programa pt/index.htm>. Acesso em: 30 jun. 2005.

COLIGAÇÃO POR UM BRASIL DECENTE. Programa de governo. Disponível em: <http://www.psdb.org.br/biblioteca.asp> $>$. Acesso em: 27 abr. 2007.

DEMOCRATAS. Propostas. Disponível em:

$<$ http://www.democratas.org.br/sobre-os-democratas/nossas-propostas $>$.

Acesso em: 28 abr. 2007.

FARIAS, Lindberg. Relatório. In: BRASIL, Congresso. Câmara dos Deputados. Comissão de Relações Exteriores e Defesa Nacional. Relatório da Comissão Externa destinada a avaliar a situação da demarcação da terra indígena Raposa Serra do Sol, no estado de Roraima. Disponível em: <http://www.camara.gov.br/Sileg/Prop Detalhe.asp?id=159214>.

Acesso em: 14 jan. 2005.

FRENTE TRABALHISTA. Desenvolvimento com justiça: o Brasil do trabalho, da produção, da inovação e da justiça. Disponível em:

<www.estadao.com.br/ext/eleicoes2002/programa ciro/pg 0034.htm>.

Acesso em: 29 jun. 2005.

LINS, Átila. Projeto de Lei. In: BRASIL, Congresso. Câmara dos Deputados. Revoga a Lei n. 9.614 de 05 de março de 1998. Disponível em: 
$<$ http://www.camara.gov.br/sileg/integras/138762.pdf>. Acesso em: $13 \mathrm{dez}$. 2003.

PARTIDO COMUNISTA DO BRASIL. Programa Socialista. Disponível em: $<$ http://www.vermelho.org.br/pcdob/programa/default.asp $>$. Acesso em: 28 jun. 2005.

PARTIDO DA REPÚBLICA. Programa. Disponível em: $<$ http://www.partidodarepublica.org.br/PR22/NOTICIAS REPUBLICANAS 2007/noticias 2007 154.html $>$. Acesso em: 28 abr. 2007.

PARTIDO DA SOCIAL DEMOCRACIA BRASILEIRA. Declaração Programática do Partido da Social Democracia Brasileira. Disponível em:

$<$ http://www.psdb.org.br/declaracaoprogramatica.asp $>$. Acesso em: 27 jun. $2005 a$.

Plano de Governo FHC - 99-02. Disponível em:

$<$ http://www.psdb.org.br/biblioteca.asp $>$. Acesso em: 27 jun. 2005b.

PARTIDO DEMOCRÁTICO TRABALHISTA. Projeto Brasil. Disponível em: $<$ http://www.pdt.org.br/partido/programa.asp>. Acesso em: 29 jun. 2005.

PARTIDO DO MOVIMENTO DEMOCRÁTICO BRASILEIRO. Estatuto, Programa, Código de Ética. 3. ed. Brasília, DF, 1999.

PARTIDO POPULAR SOCIALISTA. Ideais. Disponível em:

$<$ http://www.pps.org.br/2005/index.asp?opcao=partido\&inc partido=ideais\& portal=>. Acesso em: 27 jun. 2005.

PARTIDO PROGRESSISTA BRASILEIRO. Manifesto, Programa e Estatuto. 5. ed. Brasília, DF: Fundação Milton Campos, 1999.

PARTIDO SOCIALISMO E LIBERDADE. Programa. Disponível em: <http://www.psol.org.br>. Acesso em: 28 abr. 2007.

PARTIDO SOCIALISTA BRASILEIRO. Programa de Governo do PSB para o Brasil: Anteprojeto. Disponível em:

$<$ www.estadao.com.br/ext/eleicoes2002/programa garotinho/index.htm $>$. Acesso em: 30 jun. 2005.

Manifesto. Disponível em:

$<$ http://www.psbnacional.org.br/areas conteudos.php?idA=7\&idS=10\&idR= 10>. Acesso em: 28 abr. 2007.

PARTIDO TRABALHISTA BRASILEIRO. Programa e Estatuto. Brasília, DF, 1999.

PARTIDO VERDE. Programa. Disponível em:

$<$ http://www.partidoverde.org/programa.php $>$. Acesso em: 28 jun. 2005.

VALVERDE, Eduardo. Voto em separado. In: BRASIL, Congresso. Câmara dos Deputados. Comissão de Relações Exteriores e Defesa Nacional. Relatório da Comissão Externa destinada a avaliar a situação da demarcação da terra indígena Raposa Serra do Sol, no estado de Roraima, 06 abr. 2004. (Relator: Lindberg Farias). Disponível em: 
$<$ http://www.camara.gov.br/sileg/integras/210268.pdf>. Acesso em: 14 jan. 2005.

\section{Textos e figuras retirados de portais eletrônicos}

AGÊNCIA NACIONAL DE AVIAÇÃO CIVIL. Histórico. Disponível em: $<$ http://www.anac.gov.br/anac/historicoAnac.asp>. Acesso em: 19 abr. 2007.

CINDACTA III - Terceiro Centro Integrado de Defesa Aérea e Controle do Tráfego Aéreo. Missão. Disponível em: <http://www.cindacta3.aer.mil.br/>> Acesso em: 20 abr. 2007.

COMARA - Comissão de Aeroportos da Amazônia. Missão. Disponível em: http://www.comara.aer.mil.br/. Acesso em: 19 dez. 2006.

EXÉRCITO BRASILEIRO. Escola de Comando e Estado-Maior do Exército. Centro de Estudos Estratégicos. O Mercado Comum do Sul (MERCOSUL): reflexos para o poder militar. Rio de Janeiro, 2003a.

Secretaria Geral do Exército. Medalha de Serviço Amazônico. Disponível em: <http://www.sgex.eb.mil.br>. Acesso em: 21 jan. 2003b.

Centro de Comunicação Social do Exército. Entenda a Operação Tapuru. Disponível em:

$<$ http://www.exercito.gov.br/03Brafor/operacoes/tapuru/entenda/0061705.ht m >. Acesso em: 17 fev. 2004.

Centro de Comunicação Social do Exército. Místicas da Amazônia: Região Mendonça Furtado. Disponível em:

$<$ http://www.exercito.gov.br/NE/2001/04/9823/cdoc823.htm>. Acesso em: 16 fev. 2005a.

Centro de Comunicação Social do Exército. Operação Marajó. Apresentação. Disponível em:

$<$ http://www.exercito.gov.br/03Brafor/operacoes/marajo/indice.htm>. Acesso em: 23 jan. 2005b.

Centro de Comunicação Social do Exército. Operação Marajó. Atuação da Força de Resistência. Disponível em:

$<$ http://www.exercito.gov.br/03Brafor/operacoes/marajo/0080510.htm. Acesso em: 23 jan. 2005c.

- Centro de Comunicação Social do Exército. Operação Marajó. Conhecendo Melhor a Força de Resistência. Disponível em:

http://www.exercito.gov.br/03Brafor/operacoes/marajo/0110510.htm>.

Acesso em: 23 jan. 2005d.

Centro de Comunicação Social do Exército. Organizações Militares. Disponível em: <http://www.exercito.gov.br/060Ms/letraA.htm>. Acesso em: 12 dez. 2006a.

- Centro de Comunicação Social do Exército. $5^{\circ}$ Batalhão de Engenharia de Construção - Batalhão Carlos Aloysio Weber. Disponível em: 
$<$ http://www.exercito.gov.br/06OMs/Engenhar/Const/5bec/indice.htm>. Acesso em: 17 nov. 2006b.

- $6^{0}$ Batalhão de Engenharia de Construção - Batalhão Simón Bolívar. Disponível em:

$<$ http://www.6becnst.eb.mil.br/portuques/07 nossahistoria/historindex.htm $>$. Acesso em: 17 nov. 2006c.

- Centro de Comunicação Social do Exército. 70 Batalhão de Engenharia de Construção. Disponível em:

$<$ http://www.exercito.gov.br/06OMs/Engenhar/Const/7bec/indice.htm>. Acesso em: 17 nov. 2006d.

- Centro de Comunicação Social do Exército. $8^{\circ}$ Batalhão de Engenharia de Construção.

Disponível em: <http://www.doc.eb.mil.br/estrutura/8bec.htm>.

Acesso em: 17 nov. 2006 e.

Centro de Comunicação Social do Exército. 21 Companhia de Engenharia de Construção. Disponível em:

$<$ http://www.exercito.gov.br/06OMs/Engenhar/Const/21ciaconst/indice.htm>

. Acesso em: 17 nov. 2006f.

Centro de Comunicação Social do Exército. Canção do Soldado da Amazônia. Disponível em:

$<$ http://www.exercito.gov.br/03ativid/Amazonia/cancao.htm>. Acesso em: 08 out. 2006g.

$6^{\circ}$ Batalhão de Engenharia de Construção - Batalhão Simón Bolívar. Símbolos. Disponível em:

$<$ http://www.6becnst.eb.mil.br/portugues/05 centrocivico/05 52 6bec/index simbolo.htm>. Acesso em: 17 nov. 2006h.

$6^{\circ}$ Batalhão de Engenharia de Construção - Batalhão Simón Bolívar. Canção do $6^{\circ}$ BEC. Disponível em:

$<$ http://www.6becnst.eb.mil.br/portugues/05 centrocivico/05 52 6bec/index hinos.htm>. Acesso em: 17 nov. $2006 \mathrm{i}$.

. Centro de Comunicação Social do Exército. Noticiário do Exército. O distintivo do Comando Militar da Amazônia. Disponível em:

$<$ http://www.exercito.gov.br/NE/2000/NE/ne9781/curio781.htm>. Acesso em 08 de out. 2006j.

Centro de Comunicação Social do Exército. Noticiário do Exército. Oração do Guerreiro de Selva. Disponível em:

$<$ http://www.exercito.gov.br/NE/2000/NE/ne9785/curio785.htm>. Acesso em: 08 out. 2006l.

$4^{\circ}$ Esquadrão de Aviação do Exército. Disponível em: http://www.4esqdavex.eb.mil.br/. Acesso em: 08 out. 2006m.

Centro de Comunicação Social do Exército. A História da Amazônia Portuguesa. Disponível em: <http://www.exercito.gov.br/03ativid/Amazonia/0031106.htm\#>.

Acesso em: 12 abr. 2007a. 
. Centro de Comunicação Social do Exército. Comando Militar da Amazônia. Disponível em:

$<$ http://www.exercito.gov.br/06OMs/Comandos/CMA/indice.htm>.

Acesso em: 27 fev. 2007b.

$1^{a}$ Brigada de Infantaria de Selva - Brigada Lobo D'Almada. Disponível em: <http://www.1bdainfsl.eb.mil.br/hist.html>. Acesso em: 27 fev. 2007c.

- Centro de Comunicação Social do Exército. $16^{a}$ Brigada de Infantaria de Selva - Brigada das Missões.

Disponível em:

$<$ http://www.exercito.gov.br/06OMs/Infantar/Brigada/Selva/16bdasl/indice.ht m>. Acesso em: 27 fev. 2007d.

- Centro de Comunicação Social do Exército. $2^{a}$ Brigada de Infantaria de Selva - Brigada Ararigbóia. Disponível em:

$<$ http://www.exercito.gov.br/06OMs/Infantar/Brigada/Selva/2bdainfsl/indice.h tm>. Acesso em: 27 fev. 2007e.

- Centro de Comunicação Social do Exército. $17^{a}$ Brigada de Infantaria de Selva - Brigada Príncipe da Beira. Disponível em:

$<$ http://www.exercito.gov.br/06OMs/Infantar/Brigada/Selva/17bdasl/indice.ht m>. Acesso em: 27 fev. $2007 f$

Centro de Comunicação Social do Exército. $23^{a}$ Brigada de Infantaria de Selva. Disponível em:

$<$ http://www.exercito.gov.br/06OMs/Infantar/Brigada/Selva/23bdasl/indice.ht m>. Acesso em: $27 \mathrm{fev}$. 2007g.

- Centro de Comunicação Social do Exército. Mestre-de-Campo Antonio Dias Cardoso (O Mestre da Emboscada). Disponível em: $<$ http://www.exercito.gov.br/01/nstit/Historia/Guararap/diascardo.htm>. Acesso em: 17 fev. 2007h.

. Centro de Instrução de Guerra na Selva. Onça Pintada. Disponível em: <http://www.cigs.ensino.eb.br/simbolos onca.htm >. Acesso em: 18 fev. $2007 i$.

- Centro de Comunicação Social do Exército. Operação Timbó. Concepção. Disponível em: <http://www.timbo.mil.br/>. Acesso em: 10 mar. 2007j.

Centro de Comunicação Social do Exército. Operação Tucunaré. Sobre a Operação Tucunaré. Disponível em:

$<$ http://www.tucunare.mil.br/sobre.htm>. Acesso em: 10 mar. 2007l.

FORÇA AÉREA BRASILEIRA. $1^{\circ} / 8^{\circ}$ GAv - Esquadrão Falcão. Disponível em: <http://www.fab.mil.br/aeronaves/index.htm>. Acesso em: 11 jun. 2005a.

$3^{\circ} / 7^{\circ}$ GAv - Esquadrão Netuno. Disponível em:

$<$ http://www.fab.mil.br/aeronaves/index.htm>. Acesso em: 11 jun. 2005b 
. $1^{\circ}$ ETA - Esquadrão Tracajá. Disponível em:

$<$ http://www.fab.mil.br/aeronaves/index.htm>. Acesso em: 11 jun. 2005c.

70/8 GAv - Esquadrão Harpia. Disponível em:

<http://www.fab.mil.br/aeronaves/index.htm>. Acesso em: 11 jun. 2005d.

$1^{\circ} / 9^{\circ} \mathrm{GAv}$ - Esquadrão Arara. Disponível em:

$<$ http://www.fab.mil.br/aeronaves/index.htm>. Acesso em: 11 jun. $2005 \mathrm{e}$.

$7^{\circ}$ ETA - Esquadrão Cobra. Disponível em:

$<$ http://www.fab.mil.br/aeronaves/index.htm>. Acesso em 11 jun. $2005 f$.

$2^{\circ} / 6^{\circ}$ GAv - Esquadrão Guardião. Disponível em:

$<$ http://www.fab.mil.br/aeronaves/index.htm>. Acesso em: 11 jun. 2005g.

$2^{\circ} / 3^{\circ}$ GAv - Esquadrão Grifo. Disponível em:

<http://www.fab.mil.br/aeronaves/index.htm>. Acesso em: 11 jun. 2005h.

Comando Geral de Operações Aéreas. Disponível em: $<$ http://www.fab.mil.br/HTM/comgar.htm>. Acesso em: 18 dez. 2006a.

Comando-Geral de Apoio. Disponível em:

$<$ http://www.fab.mil.br/HTM/comgap.htm>. Acesso em: 18 dez. 2006b.

Comando-Geral do Pessoal. Disponível em:

$<$ http://www.fab.mil.br/HTM/comgep.htm>. Acesso em: 18 dez. 2006c.

Comando-Geral de Tecnologia Aeroespacial. Disponível em:

<http://www.cta.br/>. Acesso em: 18 dez. 2006d.

Departamento de Controle do Espaço Aéreo. Disponível em:

$<$ http://www.decea.gov.br/home/default.asp $>$. Acesso em: 18 dez. 2006e.

Departamento de Ensino da Aeronáutica. Disponível em:

$<$ http://www.fab.mil.br/HTM/depens.htm>. Acesso em: $18 \mathrm{dez}$. 2006f.

Conselho Superior de Economia e Finanças da Aeronáutica. Disponível em: <http://www.fab.mil.br/HTM/consefa.htm>. Acesso em: 18 dez. 2006g.

$3^{\circ} / 3^{\circ} \mathrm{GAv}$ - Esquadrão Flecha. Disponível em:

$<$ http://www.fab.mil.br/aeronaves/index.htm>. Acesso em 20 dez. 2006h.

Estrutura do Comando da Aeronáutica. Disponível em:

<http://www.fab.mil.br/HTM/organograma.htm>. Acesso em: 19 abr. 2007a.

. Centro de Comunicação Social da Aeronáutica. Entenda a Lei do Tiro de Destruição. Disponível em:

$<$ http://www.reservaer.com.br/legislacao/leidoabate/entenda-leidoabate.htm. Acesso em: 21 fev. 2007b.

Operação PERBRA. Concepção. Disponível em:

$<$ http://www.fab.mil.br/fab/operacaoaerea/perbra2/index.htm>. Acesso em: 22 fev. 2007c.

Aeronaves. A-29 Super Tucano. Disponível em:

<http://www.fab.mil.br/aeronaves/index.htm>. Acesso em: 19 abr. 2007d.

. Operação COLBRA I. Concepção. Disponível em: 
$<$ http://www.fab.mil.br/fab/operacaoaerea/colbra/PORTUGUES.htm>. Acesso em: 22 fev. 2007e.

Operação VENBRA. Concepção. Disponível em:

$<$ http://www.fab.mil.br/fab/operacaoaerea/venbra4/index.htm>. Acesso em: 22 fev. $2007 f$.

$1^{\circ} / 3^{\circ}$ GAv - Esquadrão Escorpião. Disponível em:

<http://www.fab.mil.br/aeronaves/index.htm>. Acesso em: 19 abr. $2007 \mathrm{~g}$.

MAGALHÃES, Luiz Felipe de. Bandeirante do Ar. Disponível em:

$<$ http://www.incaer.aer.mil.br/>. Acesso em: 11 jun. 2005.

MARINHA DO BRASIL. Notícias. Disponível em:

$<$ https://www.mar.mil.br/menu h/noticias/noticias.htm>. Acesso em: 04 maio 2005.

Operações Navais. Operação VENBRAS. Disponível em:

$<$ https://www.mar.mil.br/menu v/operacoes navais/operacao venbras.htm. Acesso em: 04 mar. 2006a.

Amazônia Azul. Disponível em:

$<$ https://www.mar.mil.br/menu v/amazonia azul/amazonia azul.htm>.

Acesso em: 04 mar. 2006b.

- Comando do $4^{\circ}$ Distrito Naval. Marinha na Amazônia Antecedentes Históricos. Disponível em:

$<$ https://www.mar.mil.br/com4dn/antecedentes.html>. Acesso em: 03 mar. $2007 a$.

- Comando do $4^{\circ}$ Distrito Naval. Missão. Disponível em: <https://www.mar.mil.br/com4dn/missao.html>. Acesso em: 03 mar. 2007b.

Comando do $4^{\circ}$ Distrito Naval. Jurisdição. Disponível em: $<$ https://www.mar.mil.br/com4dn/om subordinadas.html>. Acesso em: 03 mar. 2007c.

Comando do $4^{\circ}$ Distrito Naval. Base Naval de Val-de-Cães. Disponível em: <https://www.mar.mil.br/com4dn/bnvc.html>. Acesso em: 03 mar. 2007d.

Comando do $4^{\circ}$ Distrito Naval. Comando do Grupamento Naval do Norte. Disponível em:

$<$ https://www.mar.mil.br/com4dn/comgrupnn.html>. Acesso em 03 mar. 2007 e.

Comando do $4^{\circ}$ Distrito Naval. Capitania dos Portos da Amazônia Oriental. Disponível em:

$<$ https://www.mar.mil.br/com4dn/cpaor.html>. Acesso em: 03 mar. $2007 f$.

Comando do $4^{\circ}$ Distrito Naval. Grupamento de Fuzileiros Navais de Belém. Disponível em:

$<$ https://www.mar.mil.br/com4dn/gptfnbe.html>. Acesso em: 03 mar. 2007g.

Comando do $4^{\circ}$ Distrito Naval. Delegacia da Capitania Fluvial de Santarém. Disponível em: 
$<$ https://www.mar.mil.br/com4dn/delcpsantarem.html>. Acesso em: 03 mar. $2007 \mathrm{~h}$.

- Comando do $4^{\circ}$ Distrito Naval. Navios. Disponível em: $<$ https://www.mar.mil.br/com4dn/navios.html >. Acesso em: 03 mar. 2007i.

. Comando do $9^{\circ}$ Distrito Naval. Missão. Disponível em: $<$ https://www.mar.mil.br/com9dn/OM/Missao.htm>. Acesso em: 04 mar. 2007j.

- Comando do $9^{\circ}$ Distrito Naval. Organizações Militares subordinadas ao Comando do $9^{\circ}$ Distrito Naval. Disponível em: $<$ https://www.mar.mil.br/com9dn/OM/omsubord.htm>. Acesso em: 04 mar. 20071 .

Disponível em:

Comando do $9^{\circ}$ Distrito Naval. Batalhão de Operações Ribeirinhas. <http://www.mar.mil.br/9dn/OM/BATRIB.htm>. Acesso em: 04 mar. 2007m. . Comando da Flotilha do Amazonas. Missão. Disponível em: $<$ https://www.mar.mil.br/flotam/missao.htm>. Acesso em: 04 mar. 2007n.

Operações Navais. Operação Ribeirex 2005. Disponível em: $<$ https://www.mar.mil.br/menu v/operacoes navais/operacao ribeirex/oper acao ribeirex.htm>.

RED DE SEGURIDAD Y DEFENSA DE AMÉRICA LATINA. Los Ministerios de Defesa. Disponível em: <http://atlas.resdal.org/atlas-ministerios.html>. Acesso em: 04 abr. 2007.

SILVA, Gilmar da. Canção do Sétimo Comando Aéreo Regional. Disponível em:

https://www.militar.com.br/modules.php?name=Letras\&file=display\&jid=118. Acesso em: 13 jun. 2006.

VILLA BÔAS. Ordem de Batalha. Diapositivo (slide) 11. A defesa da Amazônia: problemas e estratégias. 30 nov. 2005. diapositivos: color. 